\title{
المضامين الحجاجية في المصطلح البلاغي
}

\section{تأصيل ودراسة}

\section{د/ إيهاب معمد السيد المقراني"}

\section{مقدمة:}

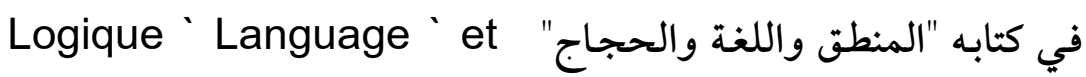

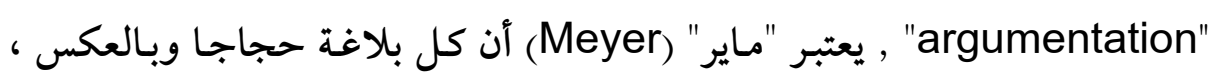

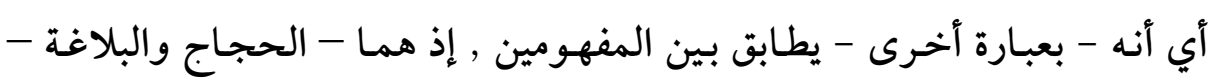

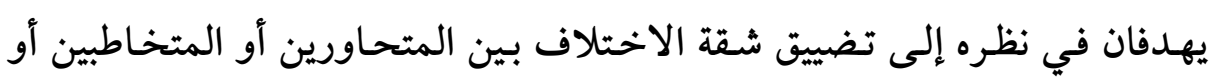

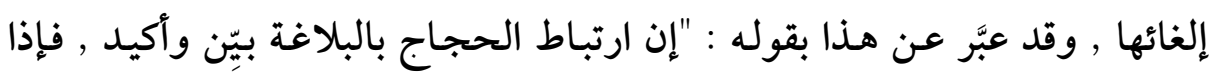

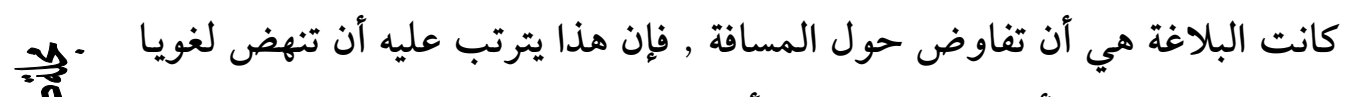

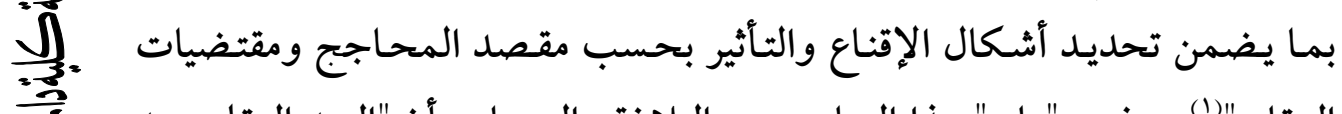

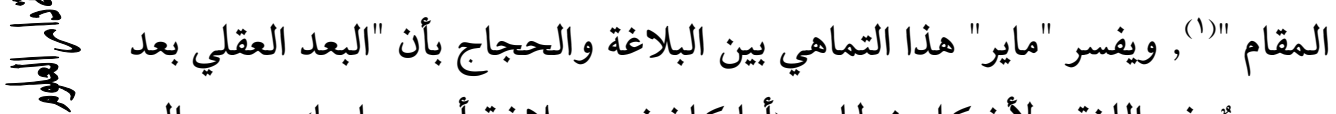

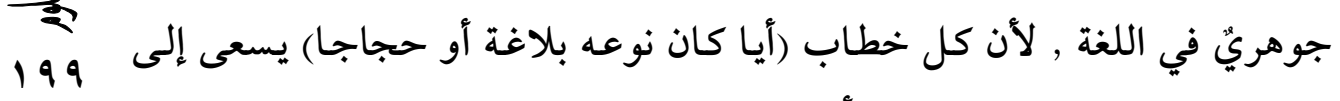

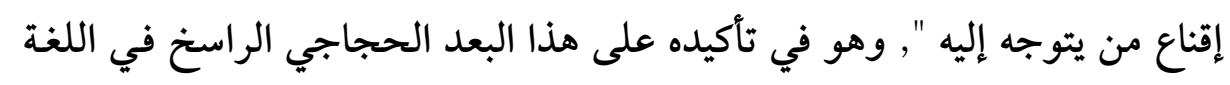

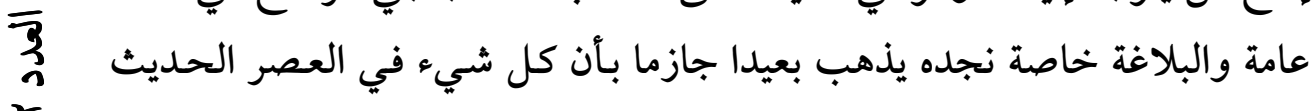

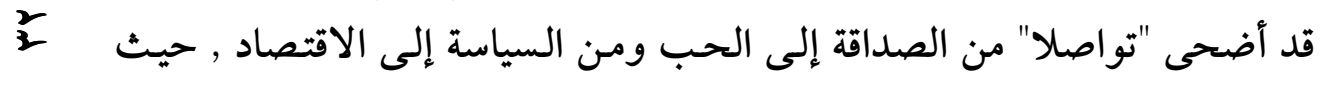

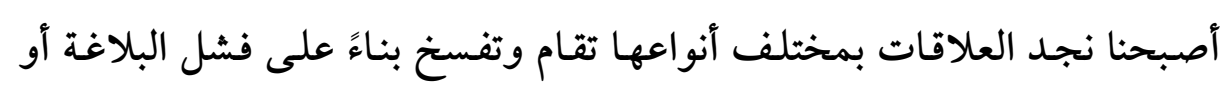

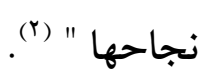
وقد زخر الموروث البلاغي العربي بأفكار رائدة في مضمار الربط بين

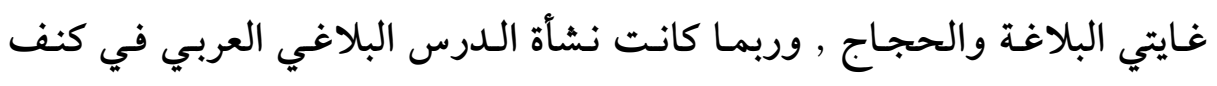

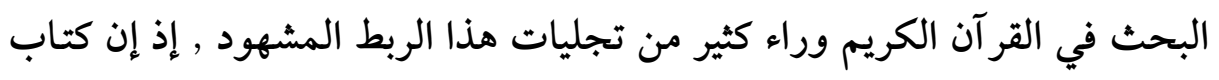
الله الكريم قد جاء برهانا وحجة وبيانا , والغاية الحجاجية في آياته الكريمة لا لا

$$
\text { " مدرس البلاغة والنقد الأدبي ، كلية الآداب - جامعة الفيوم * م }
$$


تخفى على القارئ العجل ..... وجاء التلاقح الحضاري بين الثقافة العربية - من

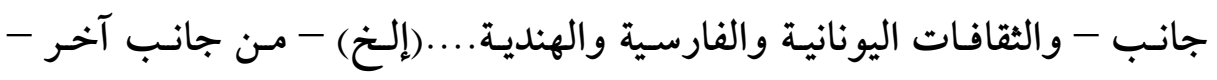

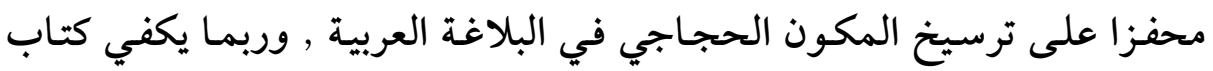

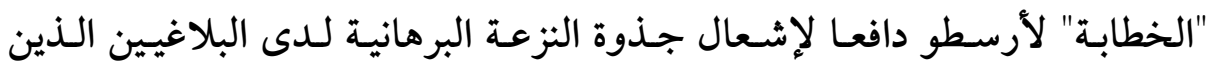

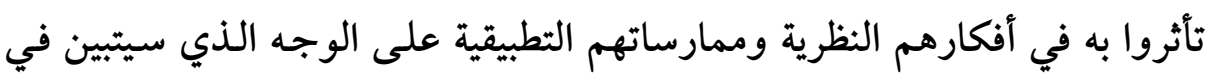
صفحات الدراسة ...

وتفصح المقارنة اللغوية بين مترادفات الحجاج - من جانب - والبلاغة

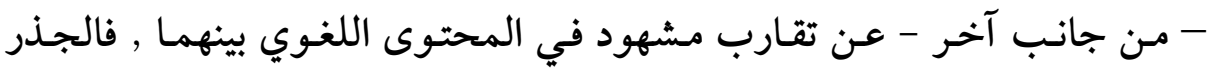

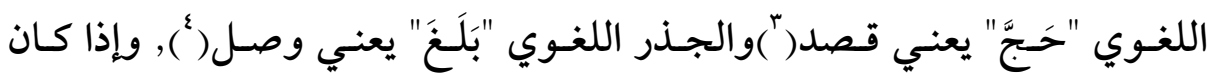

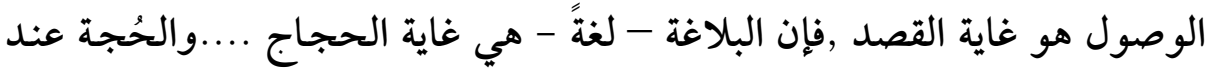

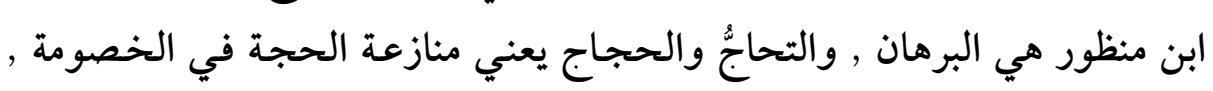

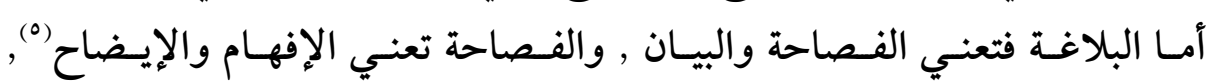

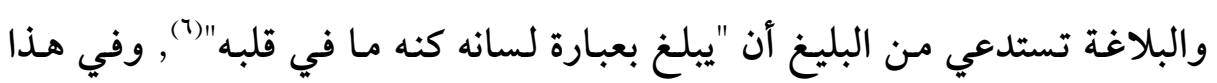

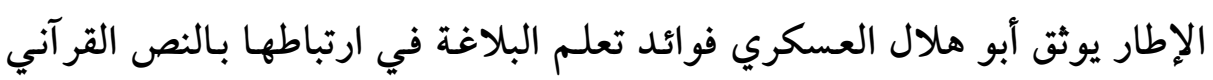

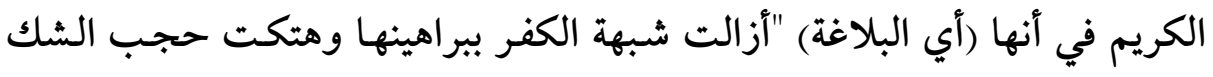
بيقينها" (v) (ن)

وإذا كانت التعريفات الاصطلاحية للبلاغة في الموروث العربي تطوُّف

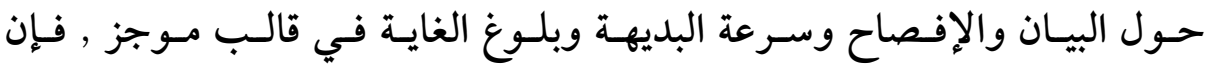

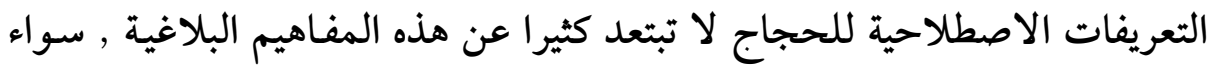

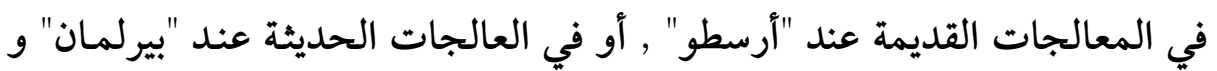

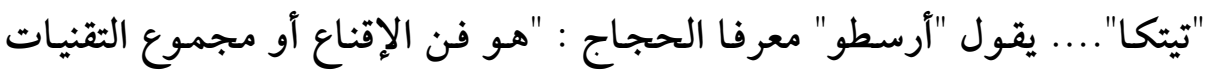

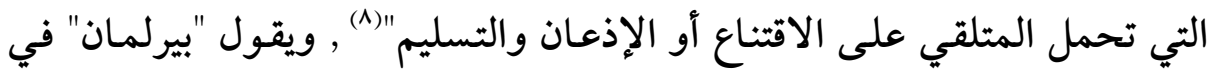

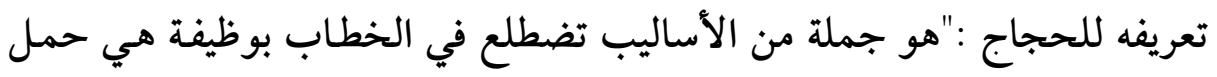

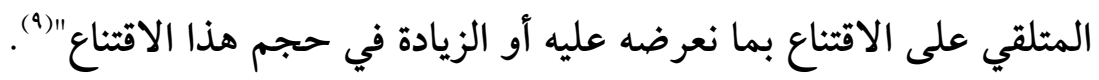




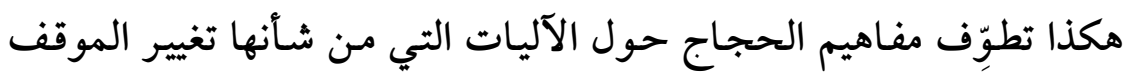

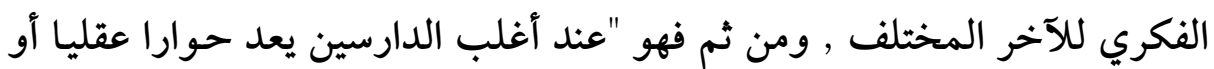
جملة من الأساليب التي تعتمد قوانين المنطق , والتي تؤدي - إن اعتمدناها في في إني

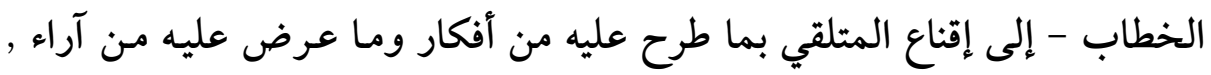

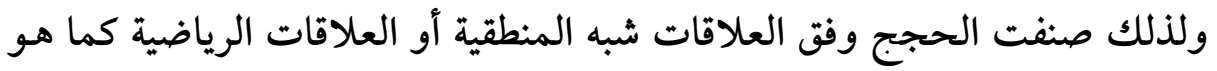

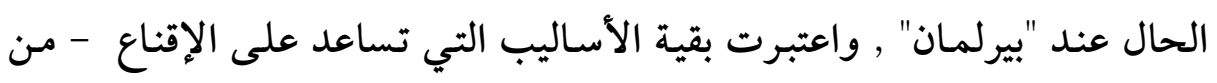

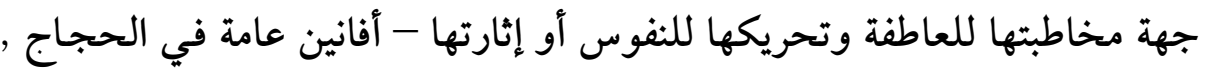

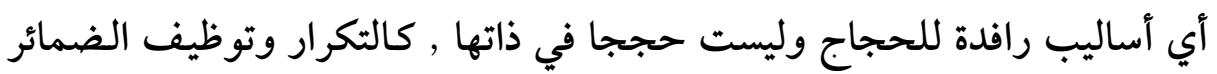

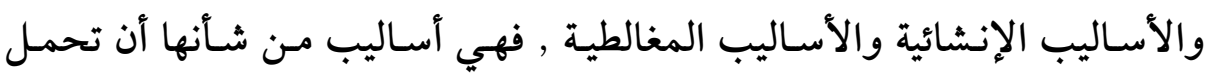

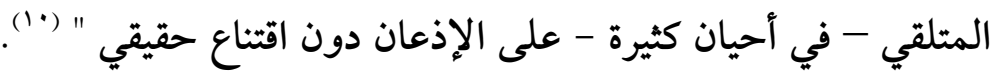

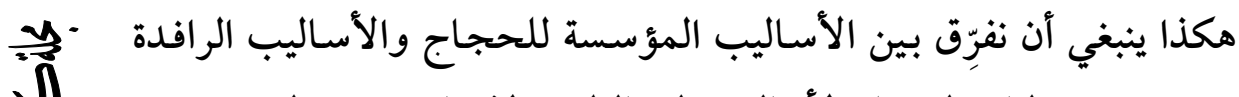

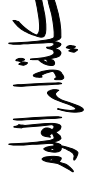

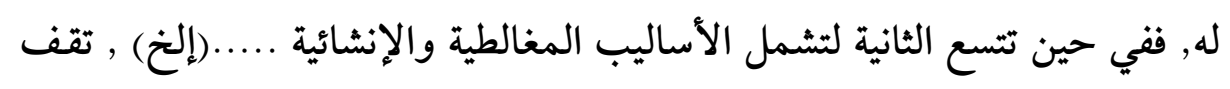

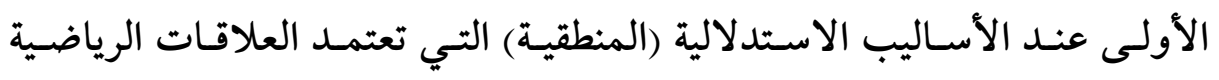

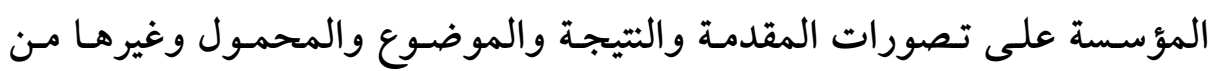

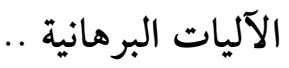
وفي تاريخ البلاغة العربية يلحظ الدارس أن الفنون البلاغية كانت تقترب -

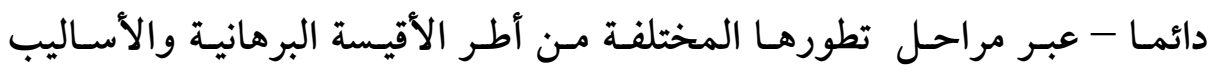

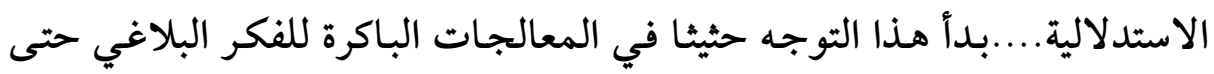

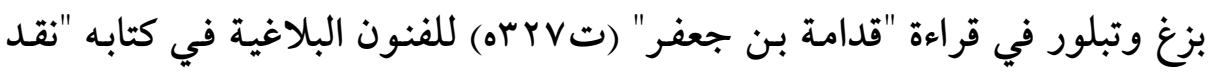

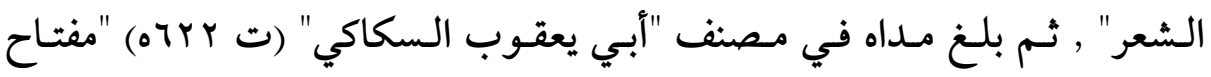

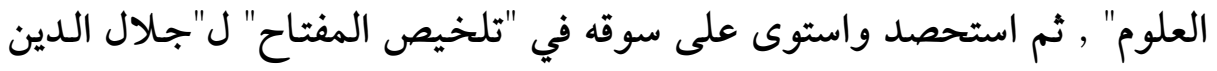

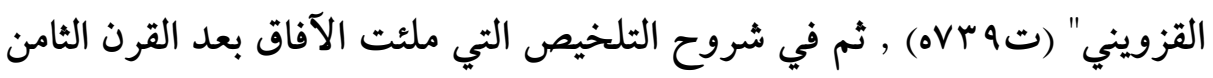
الهجري...

كـان الاتجـاه المعيـاري في الـدرس البلاغي يعضضد المحتوى الحجـاجي

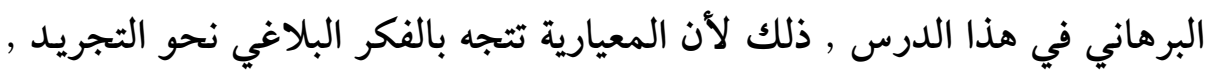


وتجريد الفنون البلاغية من سياقها الأدبي كان مؤذنا بتكريس صلاحية هذه الفنون

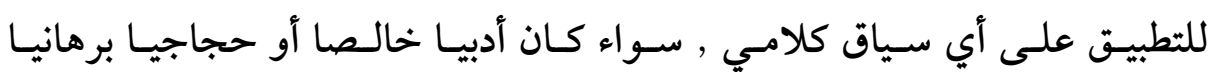

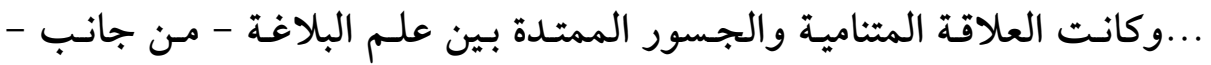

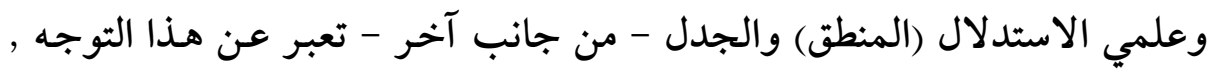

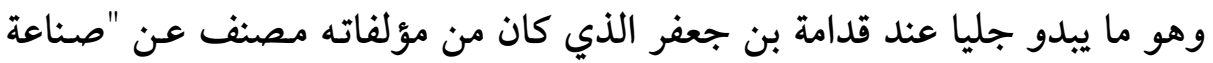

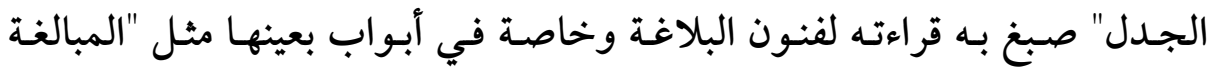

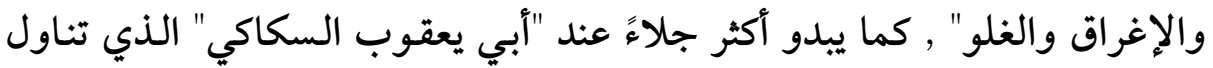

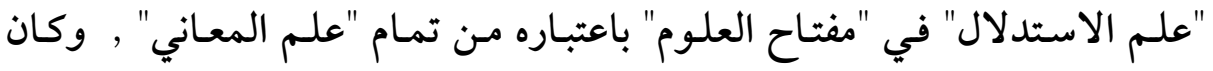

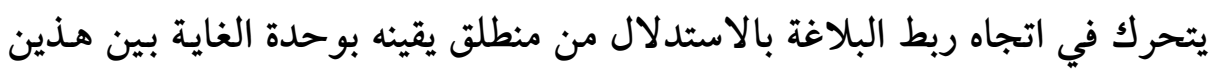

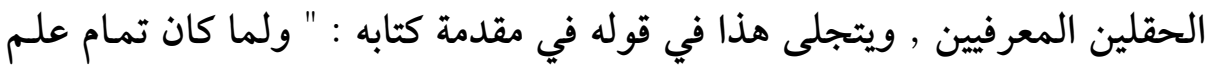

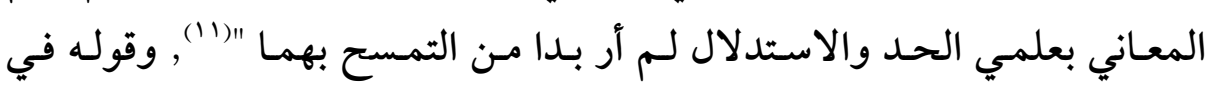

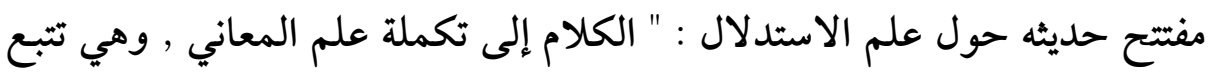

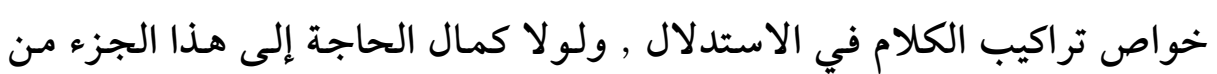

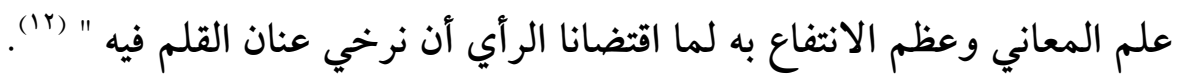

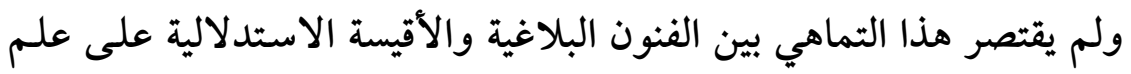

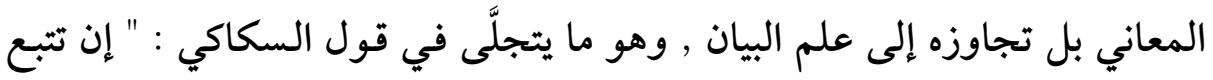

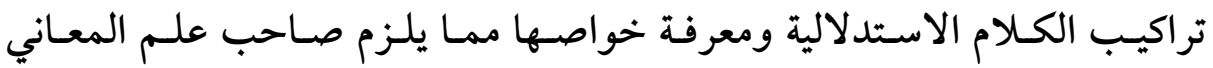

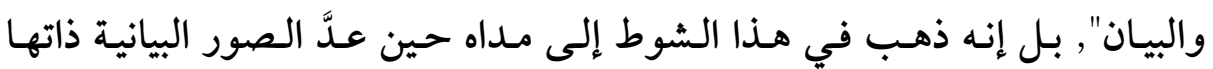

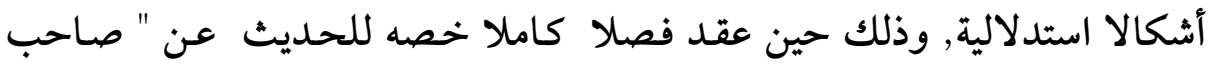

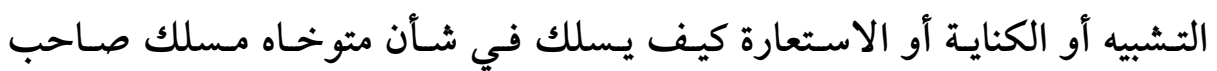

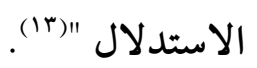
وكان من المحتمل ألا يجد هذا التوجه من السكاكي صدى عند البلاغيين ,

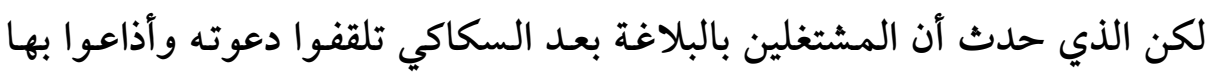
في الآفاق , حتى تحولت الفنون البلاغية في مصنفات البلاغيين المتأخرين إلى 
أقيسة استدلالية مجردة , تبتعـد عـن الإطار الأدبي بقـدر مـا تقترب مـن الإطـار

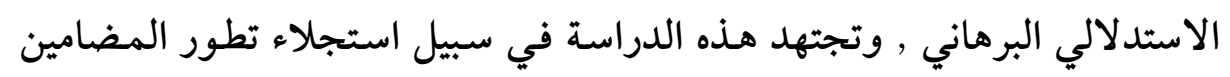

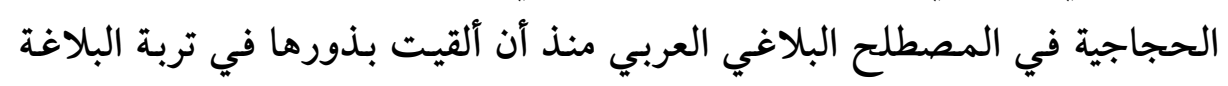

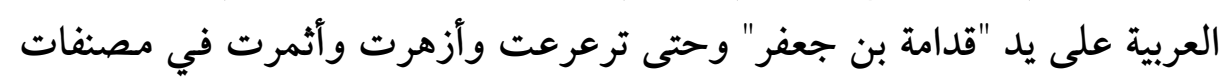
البلاغيين المتأخرين ... المبية

وفي سبيل تحقيق هـذه الغاية المنهجية تعيد الدراسة قراءة المصطلح

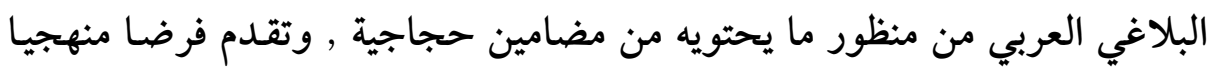
مؤداه أن المصطلح البلاغي العربي يتوزع بين قائمتين :

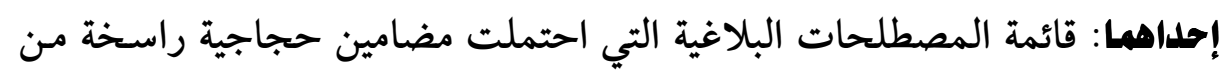

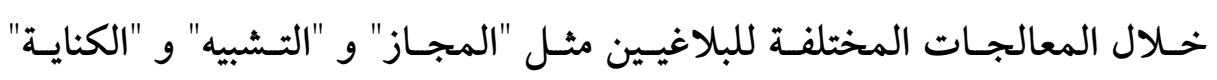
و "التخييل" و "الاستعارة" و "المقابلة" و "المجانسة"..........(إلخ).

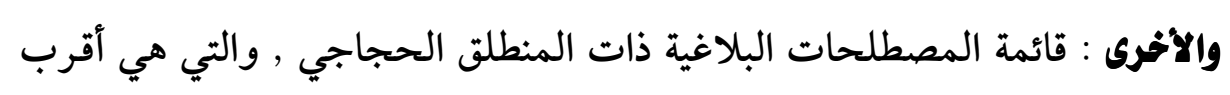

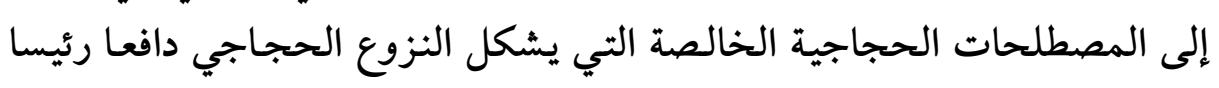

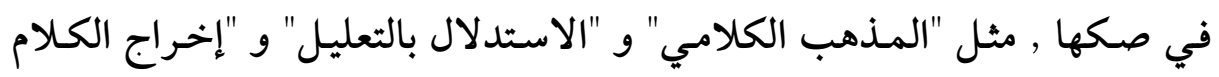

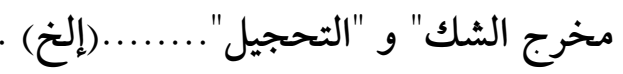

$\overline{3}$

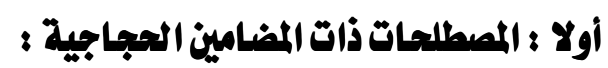

المـصطلحات المجازيـة (- التـشبيه - الاستعارة - الكنايـة - المجـاز

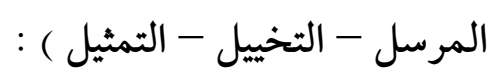

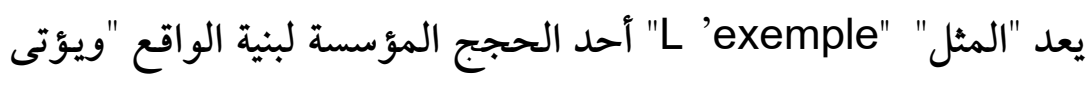

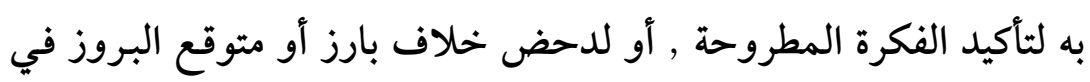

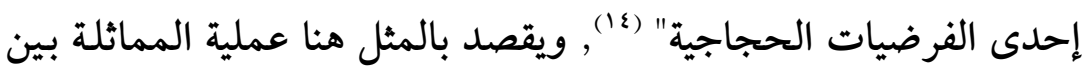

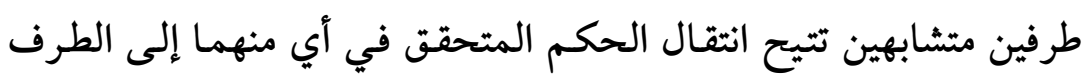

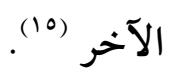

وهكذايحتوي المجاز مكونا استدلاليا رئيسا يستند على أن العملية التشبيهية

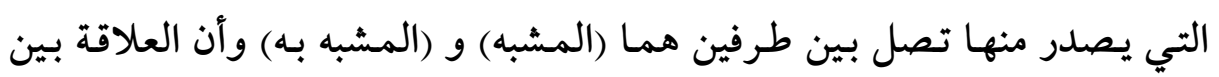




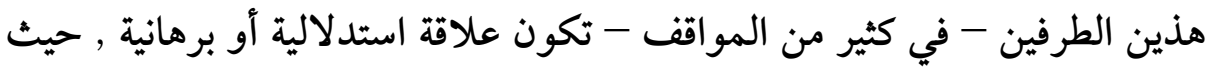

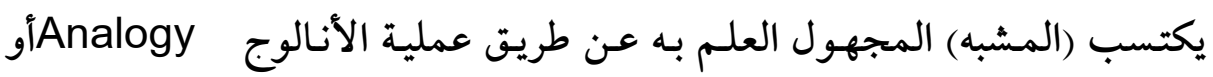

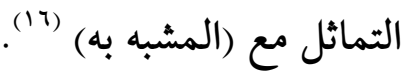
العملية التشبيهية - إذن - تحمل في ذاتها قياسا استدلاليا " وليس من قبيل

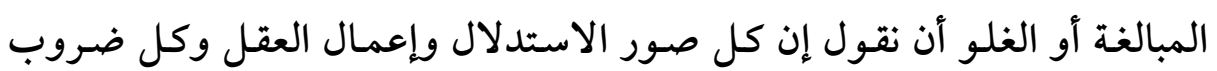
الإدراك الحسي والذهني , إنما تستند إلى قدرتنا على تمييز أوجه التشابه ذات

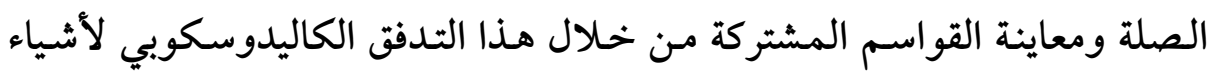

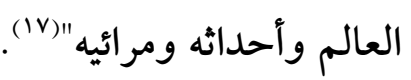

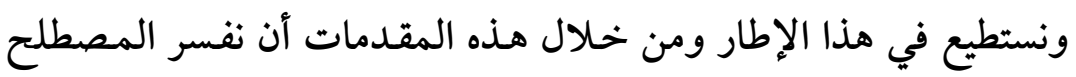

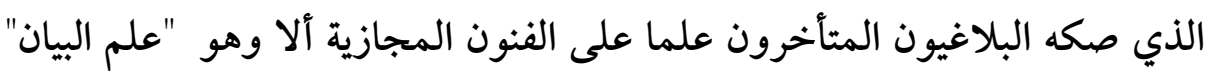

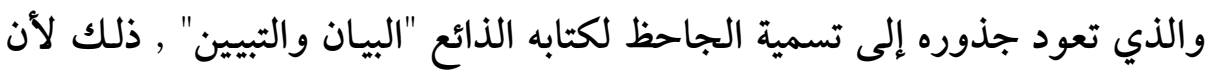

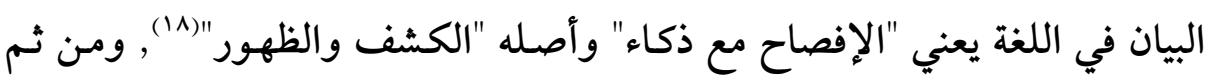

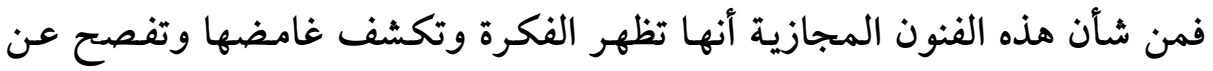

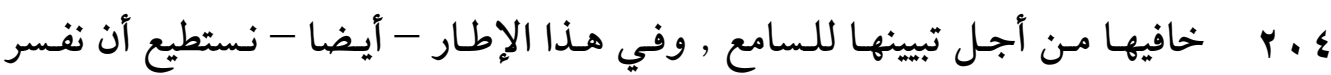

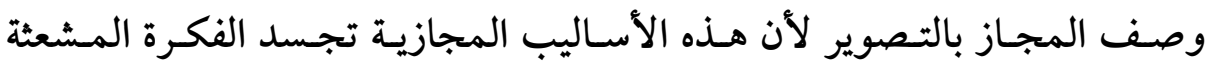
وتجمع شتاتها في صورة يسهل التعرف إليها..... بال هكذا " تعد الصور البيانية مـن تشبيه واستعارة ومجاز وكناية , وسائط

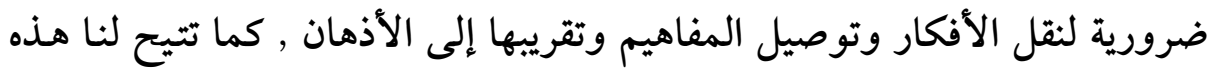

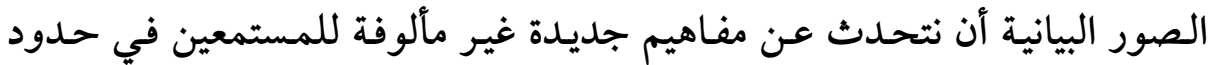
قديمة مألوفة لديهم , استنادا إلى وجه شبه معين بين الفكرة المجهولة التي نريد

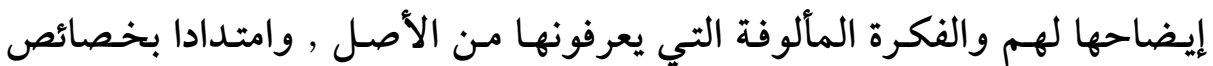

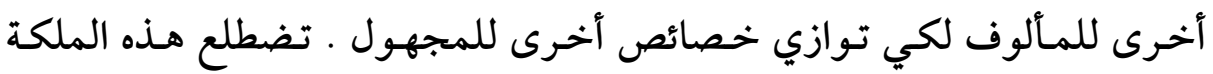

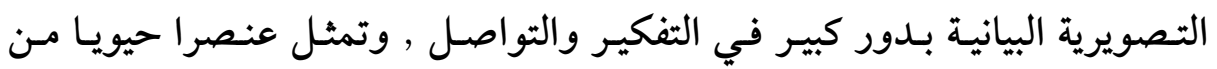

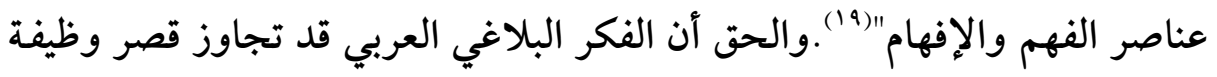


المجاز على تشبيه المجهـول بـالمعلوم حتى يُعلـم ويعـرف , وأدرك البلاغيون

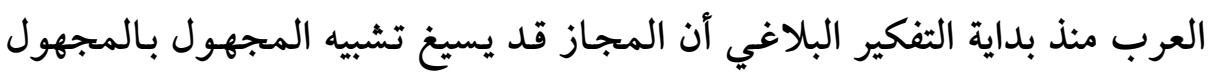

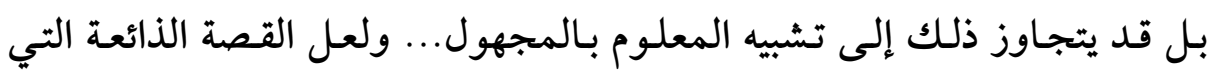

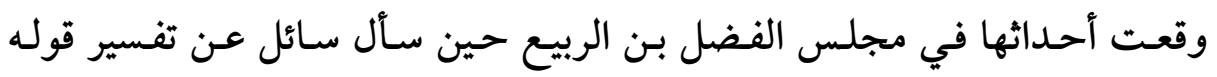

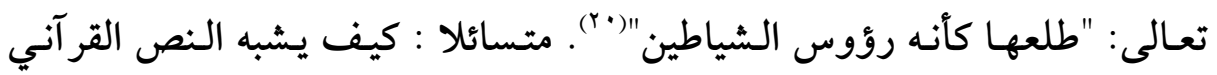

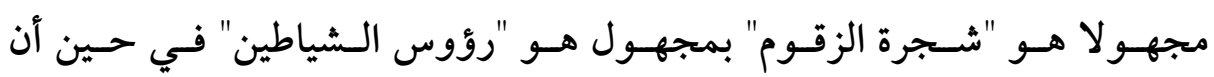

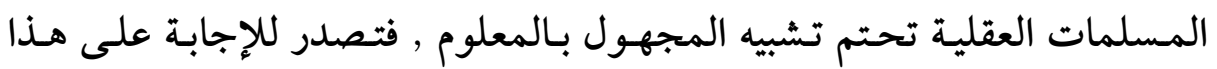

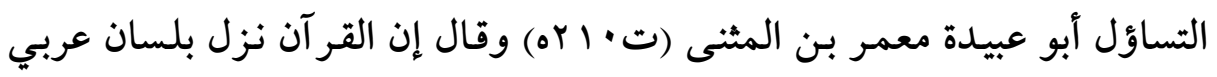

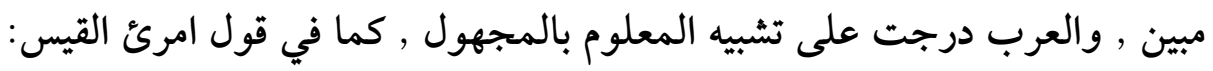

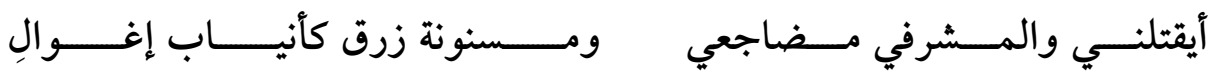

ورمح امرئ القيس (مسنونة زرق) معلوم وأنياب الغول (أنياب إغوال)

مجهول.....وأضـاف أبو عبيدة أن هـذا المجاز مـن امرئ القيس أكثر تأثيرا في

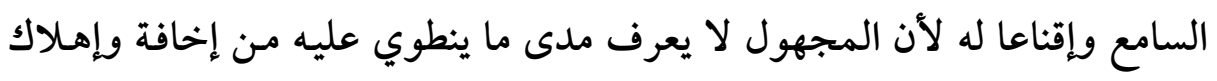

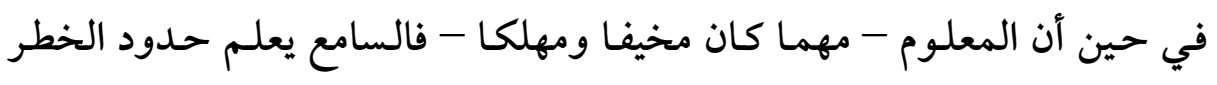
الكامن فيه .

هكذا تفصح هذه القصة عن دور آخر للمجاز يتجاوز مجرد الإيضاح

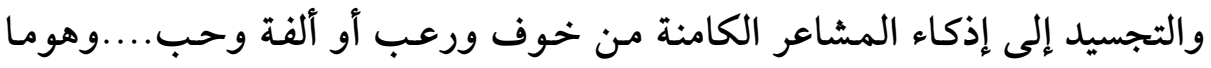

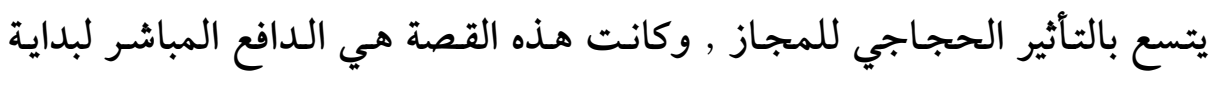

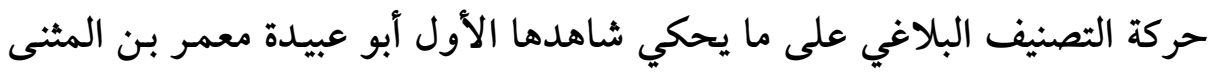

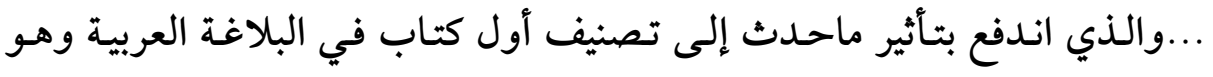

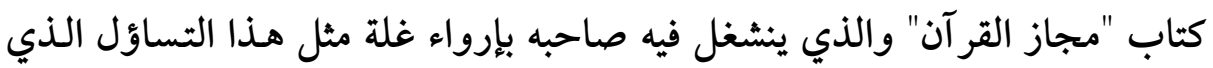
طُرح في مجلس الفضل بن الربيع , ليقدم رؤية بلاغية لغوية عميقة لتفسير مثل

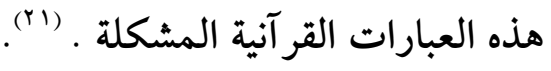


ويتجاوز المجاز - مـن خهلال تطبيقاته المختلفـة - الـدلالات الحقيقيـة

للكلمات لكي يرسخ الدلالت المجازية لها ..وهو في هذا يرسخ للقيمة البرهانية الحجاجية من وجه آخر , حيث يسعى المحاجج إلى المبالغة من أجل الاقناع

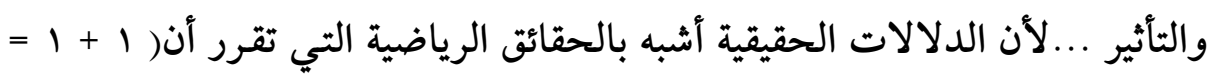

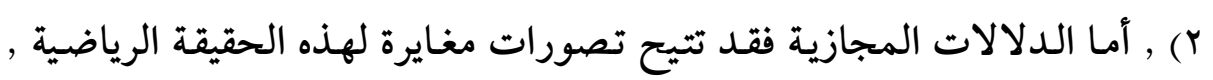

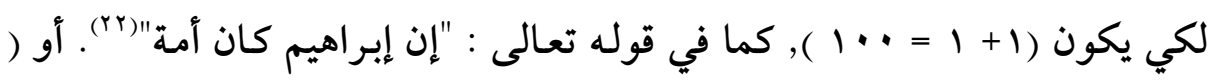
: 1

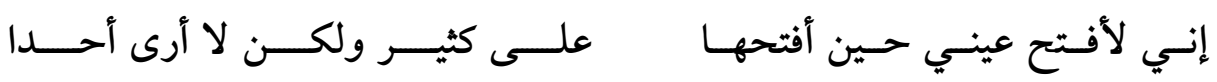

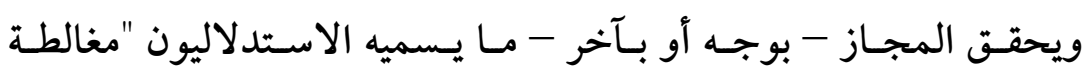

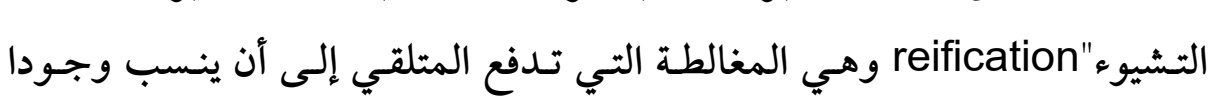

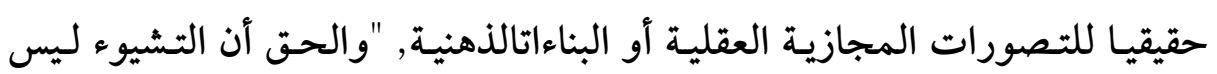

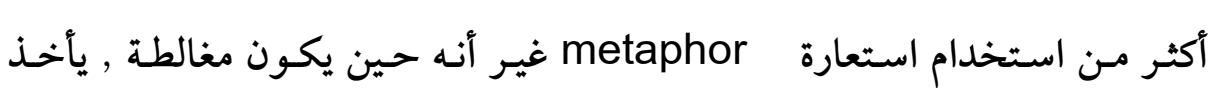

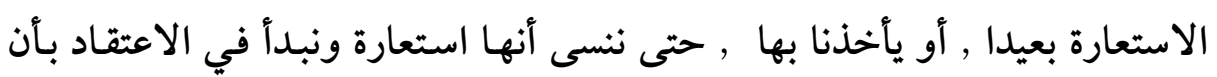
كياناتنا التصورية المجردة لديها الخصائص العيانية التي أضفيناها عليها على سبيل الاستعارة . إن طريقتنا في وصف الشيء لها بالغ الأثر فيما نعتقده عن الشيء , يعني ذلك أن انطباعاتنا عن الواقع تشيده إلى حد كبير اللغة التي نستخدمهافي وصف الواقع " (rrr), ويقدم عبد القاهر الجرجاني في معالجته للمجاز بابا يسميه "

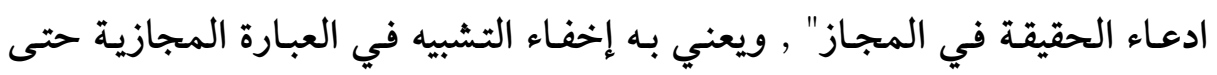
يتماهى المشبه مع المشبه به , كقول بشار :

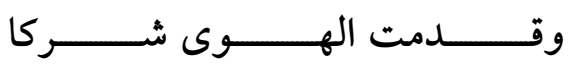

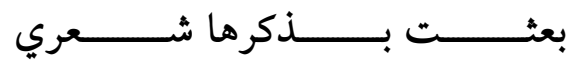

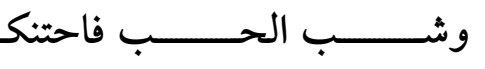

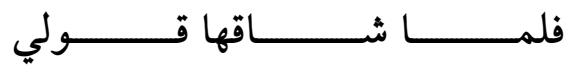

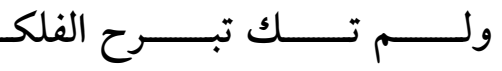

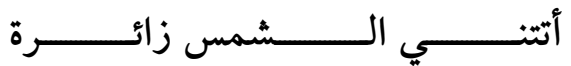

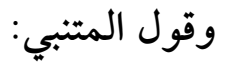


فــأرتني القمــرين فـي وقــت معــا واســتقبلت قمـــر الــسماء بوجههـــا

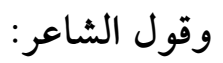

وليت غائبـة الشمسين لـم تغـب (\&)

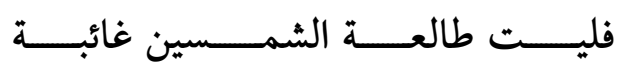

هكذا يُقَدم المجاز على وجه ينفي الخيال منه ويدعي انتماءه للحقيقة ,

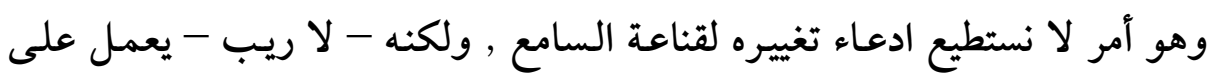

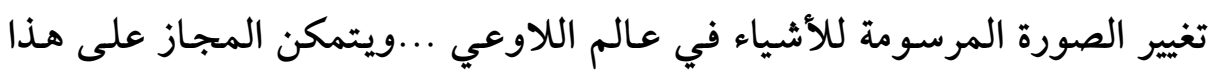

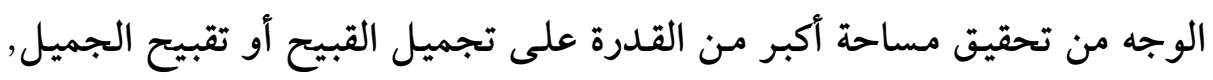

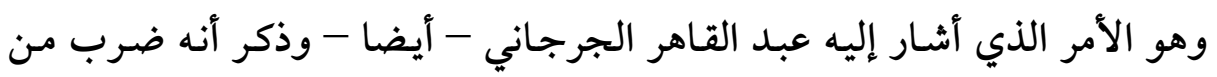

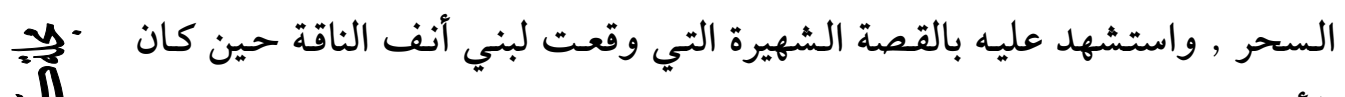

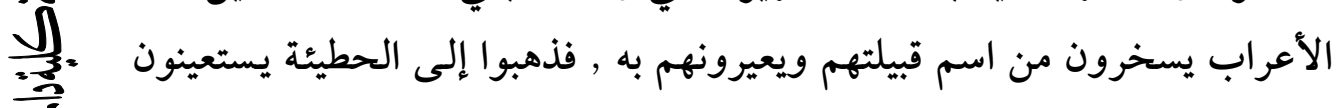

急

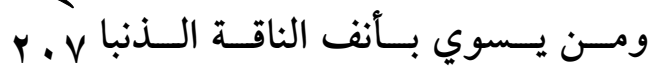
بقدرته البيانية على تغيير ما أصابهم من عنت , فقال الحطيئة في شأنهم :

$\overline{3}$

"فنفى العار وصحح الافتخار وجعل ما كان نقصا وشينا فضلا وزينا وما

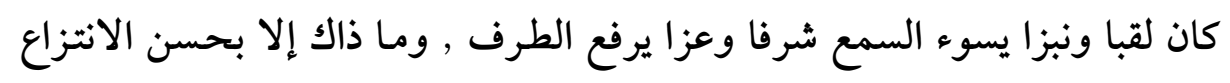
ولطف القريحة الصناع والذهن الناقد في دقائق الإحسان والإبداع , كما كساهم الطيم

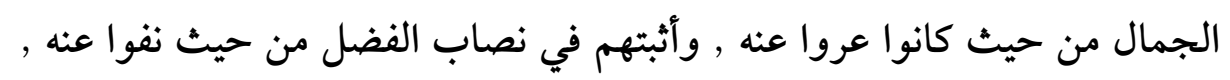

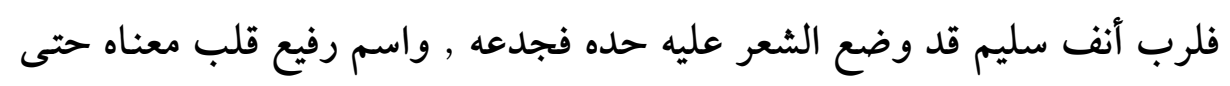
حط به صاحبه ووضعه" (10).

ويـضرب عبـد القـاهر الجرجـاني مـثلا آخــر للقـدرة البيانيـة على تغييـر

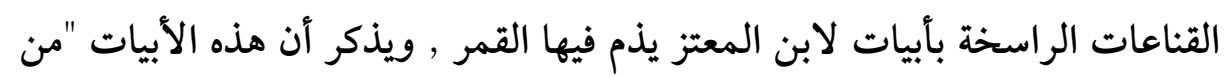

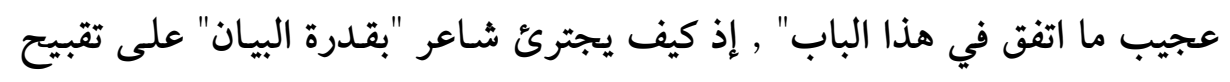

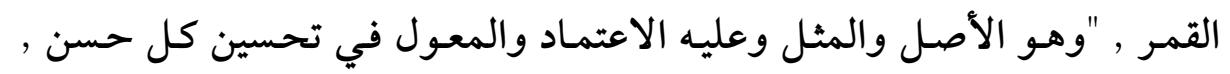




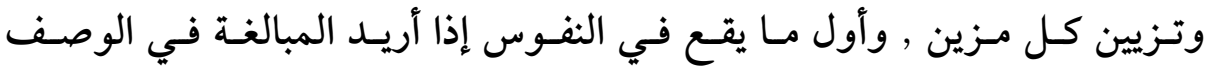

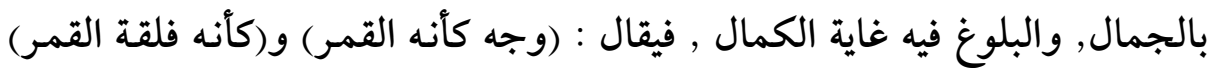

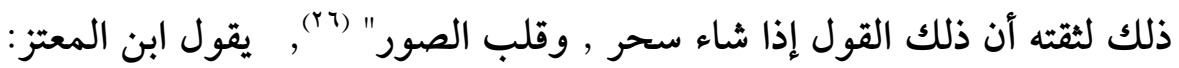

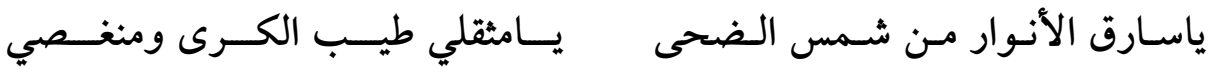

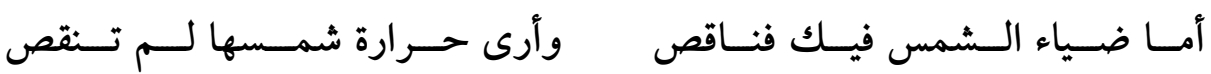

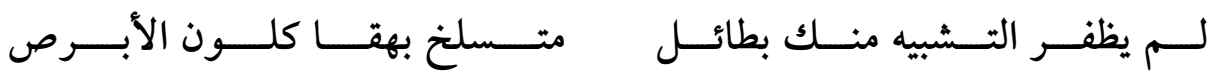

وفي هذا الإطار - أيضا - يسوق عبد القاهر مرثية أبي الحسن الأنباري

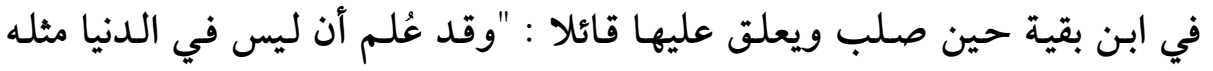

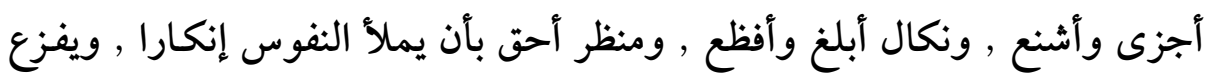

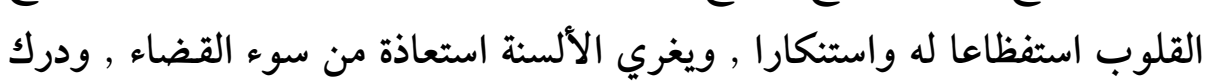

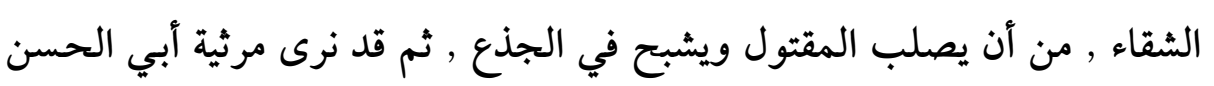

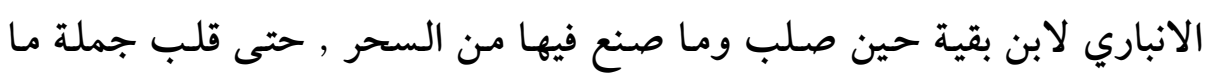

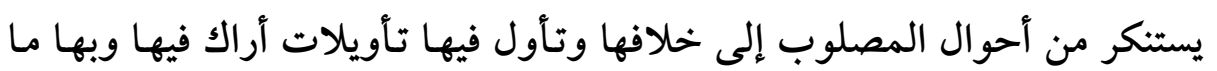
تقضى منه العجب" , يقول أبو الحسن الأنباري :

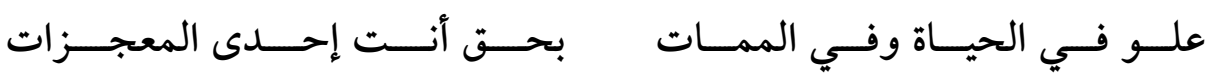

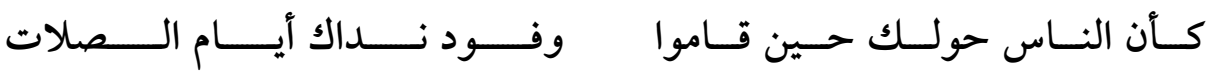

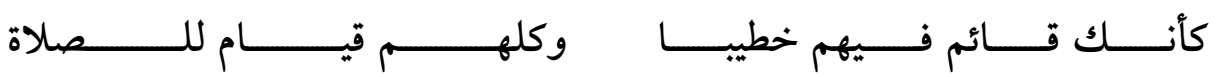

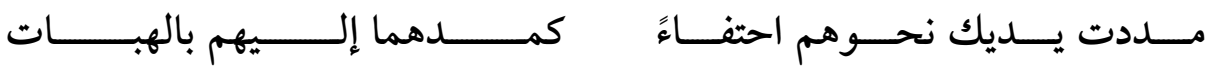

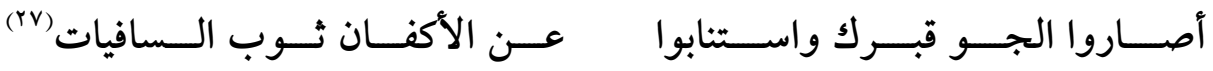
هكذا يختلف دور المجاز في العبارة بحسب اختلاف الغاية المرصودة من

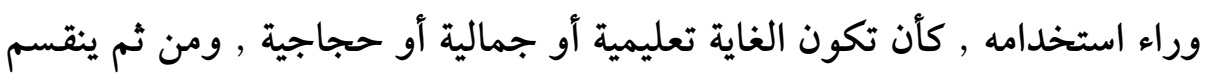

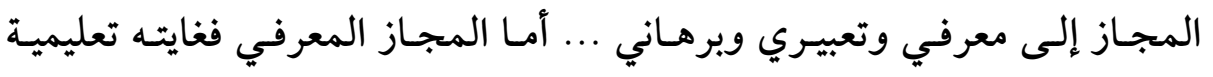

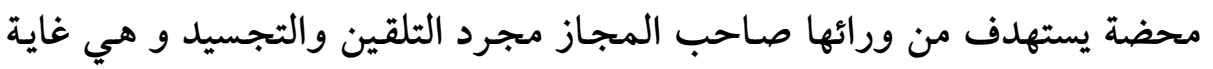


المعلم مع تلاميذه والواعظ مع مريديه , حيث يقصد المعلم إلى تحري "الفهم

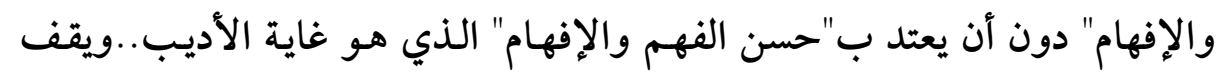

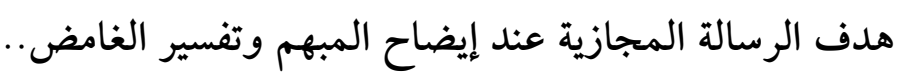

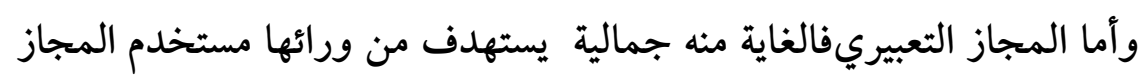

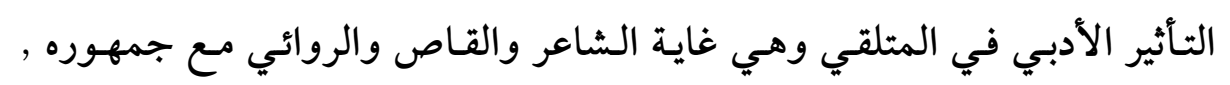

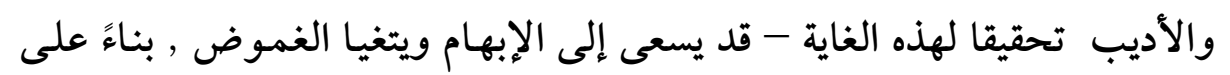

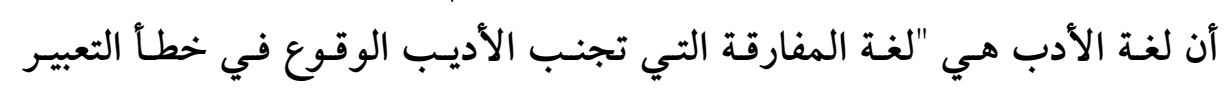
المباشر ذي البعد الواحد" (مد).

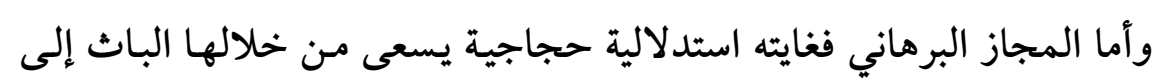

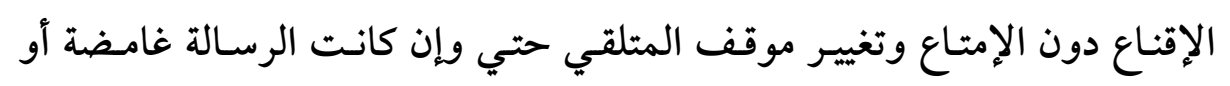

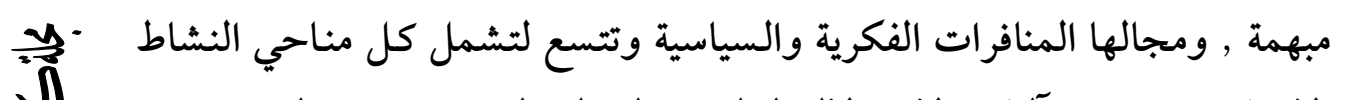

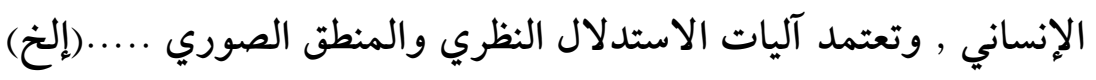

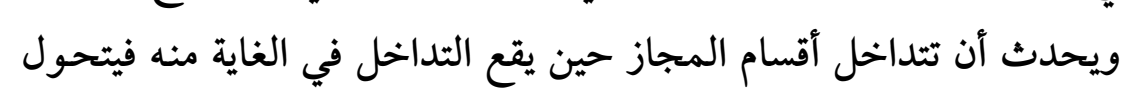

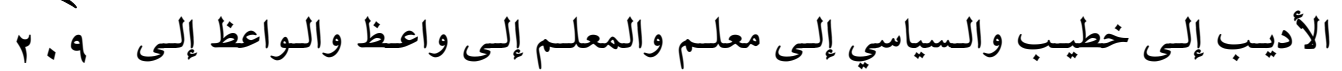

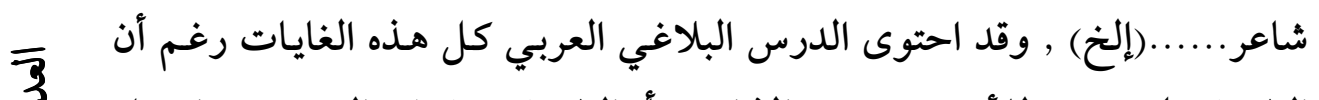

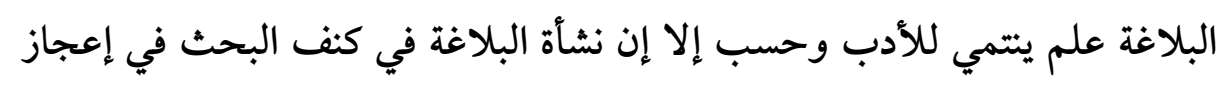

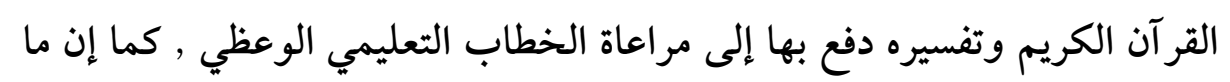

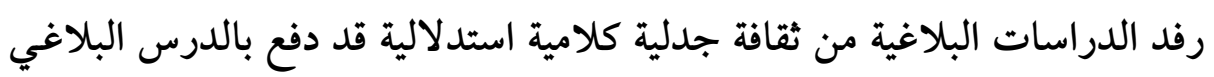

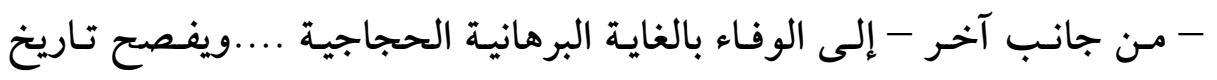

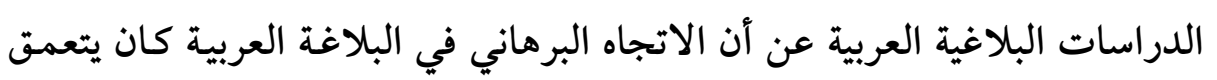

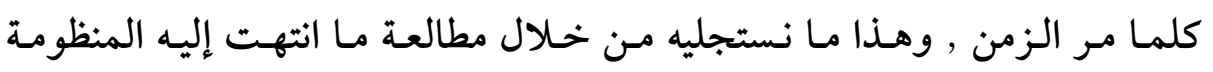

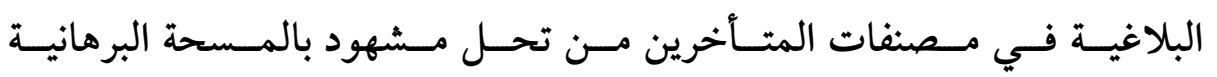

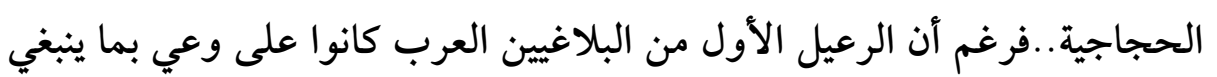

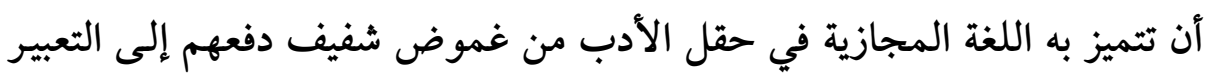
عن الأساليب البيانية بأسماء تدل في أصل الوضع اللغوي الإب من غوضي على الإخفاء والمواراه 


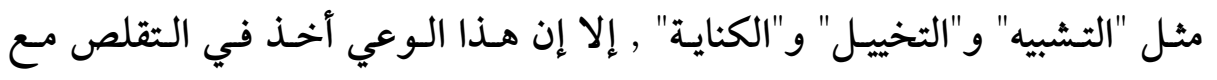

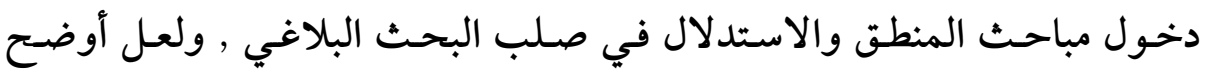

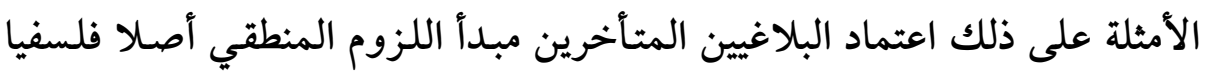

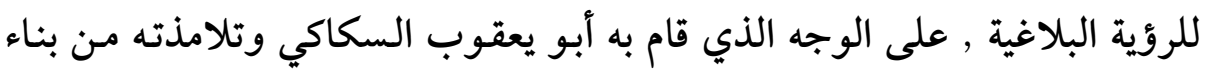

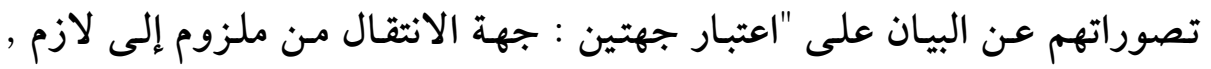

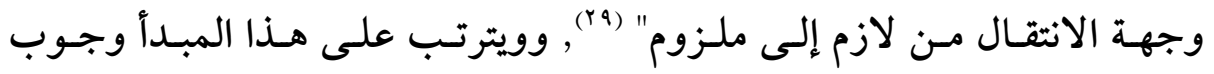

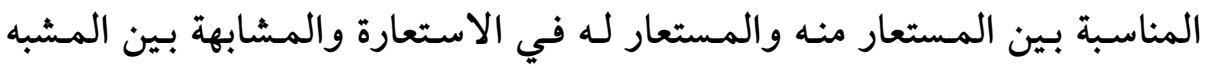

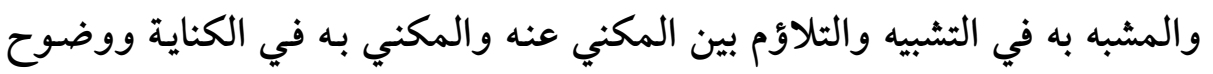
العلاقة بين طرفي المجاز في المجاز المرسل .... إن الإفراط في مراعاة مبدأ اللزوم على هذا الوجه يقترب بالمجإ المجاز إلى الغاية

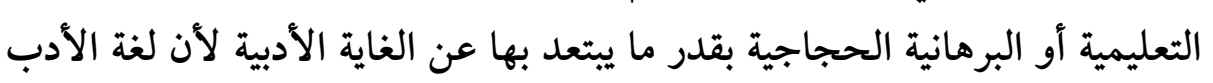
تبدأ من خرق هذا اللزوم المنطقي ولا تنتهي عنده ("r).

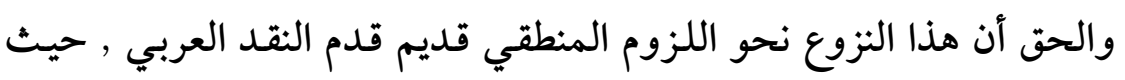

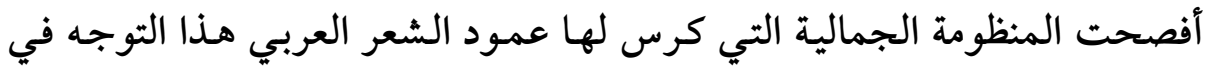

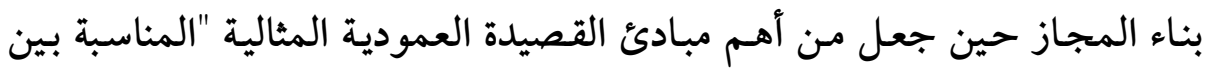

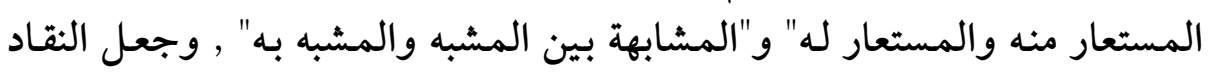

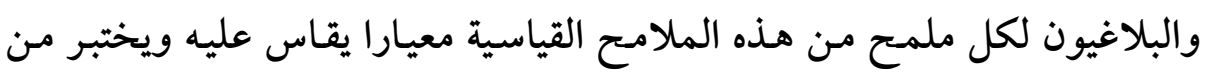

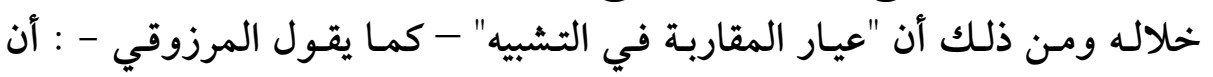

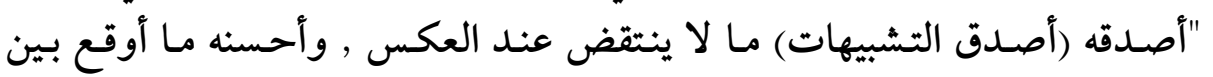

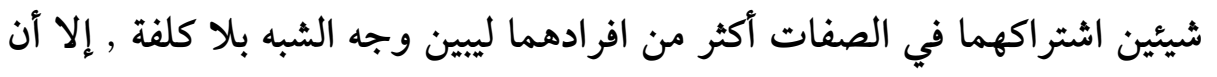

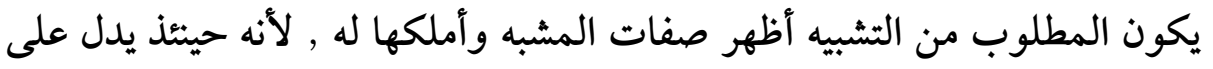

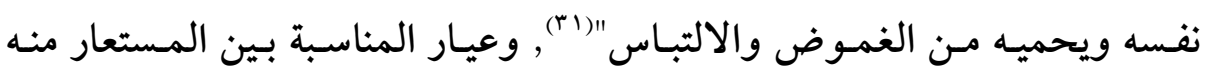

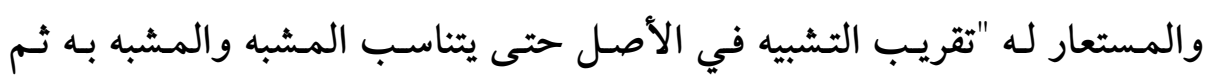

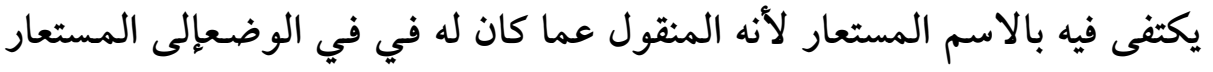

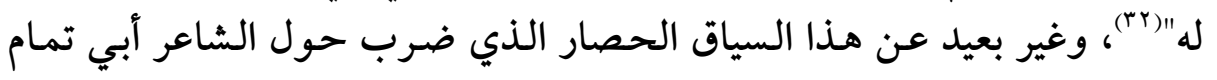

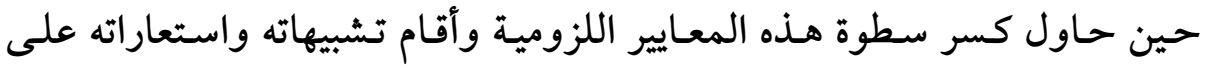


تنكب هذه المناسبة بين طرفي المجاز فنعتته كتب النقد القديم بكل نقيصة ونفت عنه كل مزية (rr) انتهى هذا الإرث الطويل من الاحتفاء بتمام المناسبة والمشابهة بين طرفي المجـاز إلى دعـوة صـريحة إلى اعتبـار الفنـون المجازيـة مجـرد وسـائل للششرح والتجسيد والتبيين عند البلاغيين المتأخرين , فحين يفسر أبو يعقوب السكاكي

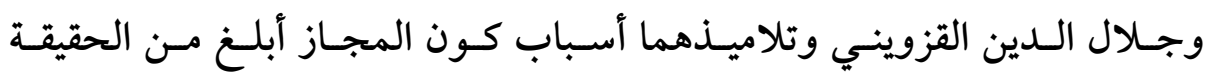

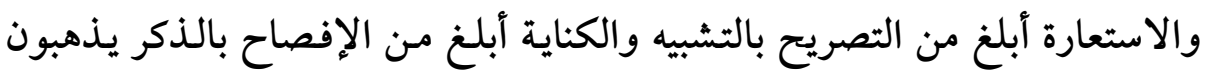
إلى أن هذه الأساليب تحتوي على وسائل إقناع لا تتوافر في التراكيب المجردة منها , حيث إن حال المبدع حين يستخدمها "كحال مدعي الشيء بيينة " أما حال

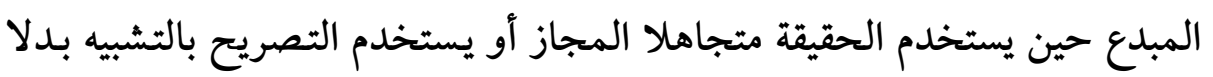

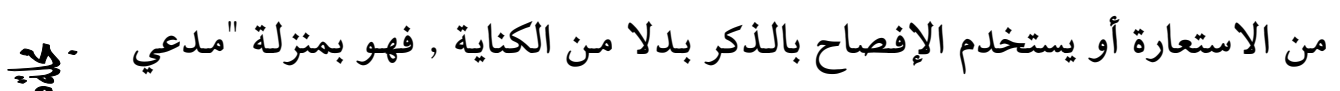

هكذا انحصر دور الأسـاليب المجازية على كونها بيّنة على الفكرة , ومـن ثـم

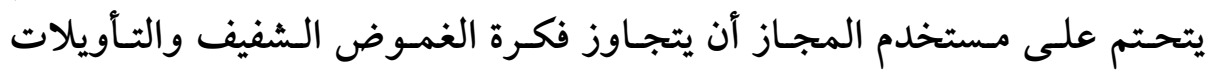

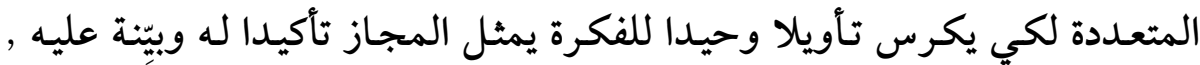

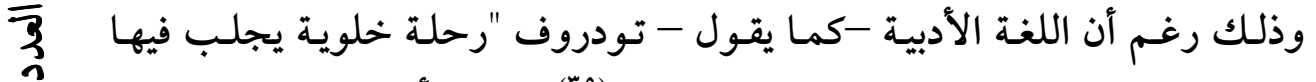

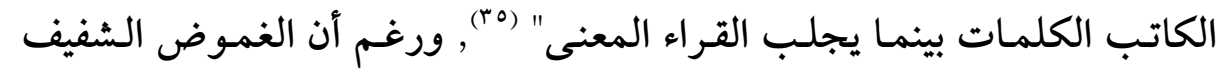

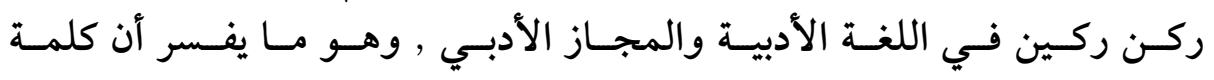

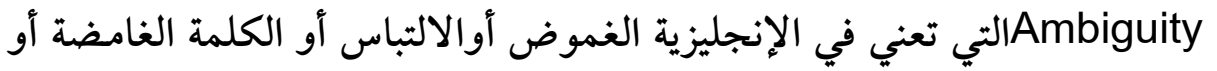

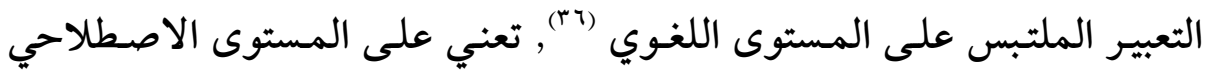

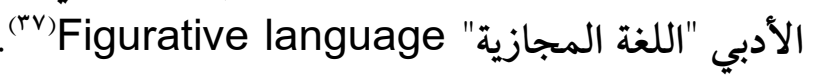

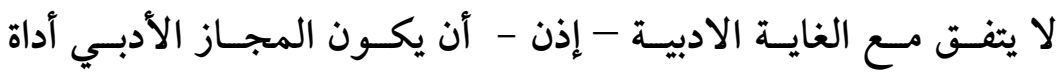

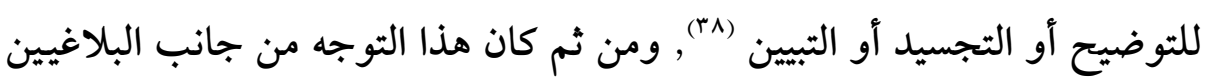
المتأخرين سببا في اقتراب البلاغة العربية من الحجاج الخطابي على الوجه الذي

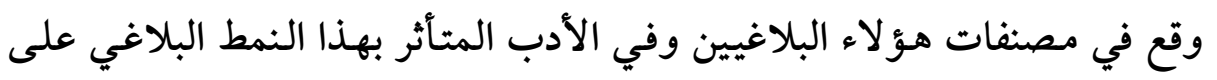


وفي أي تركيب مجازي يوجد طرفان , هما المشبه والمشبه به , وتحدد

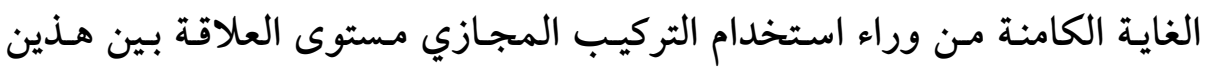

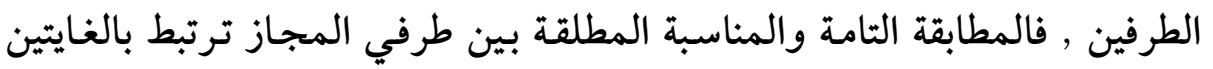

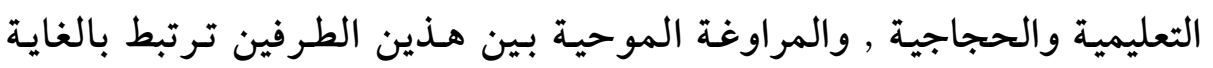
الجمالية الأدبية , ولعل هذه المفارقة تتوازى مع مفارقة أخرى أشعار أشار إليها

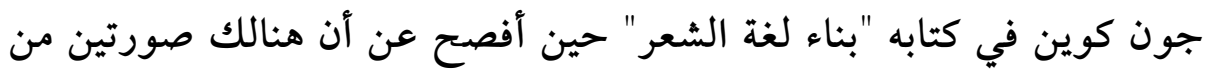

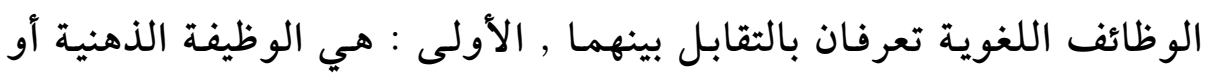

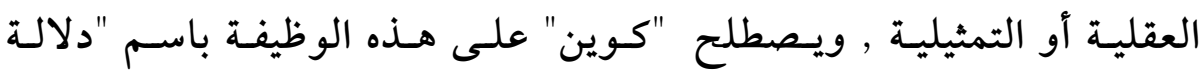

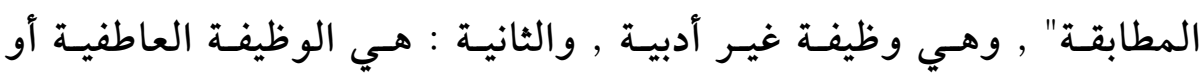

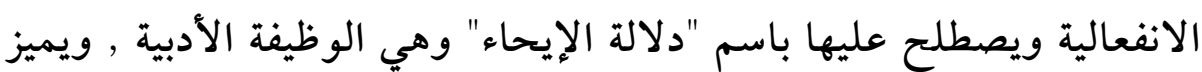

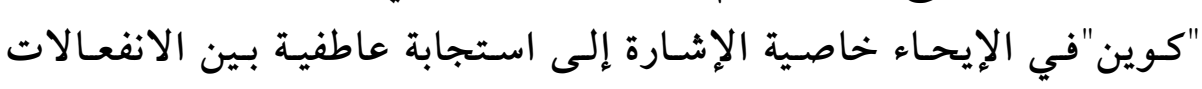

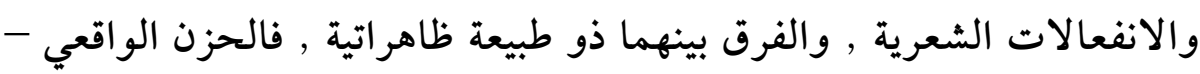

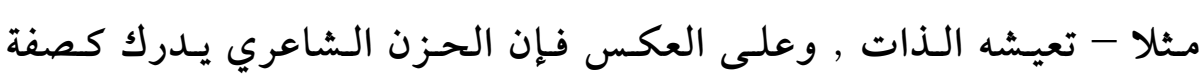
للعالم, فالأول ذاتي والثاني موضوعي , لكونه خاصية للشيء وطئه وطريقة للوعي العي به به

هكذا تهتم اللغة البرهانية بالمشترك بين طرفي العملية المجازية , في

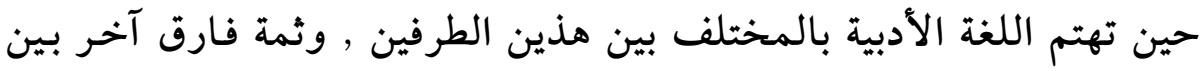

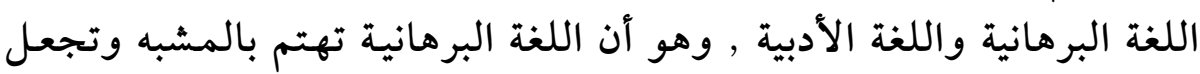

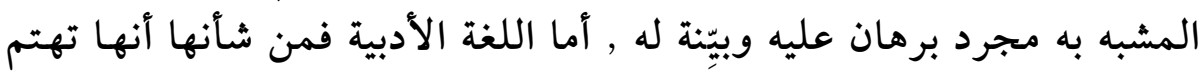

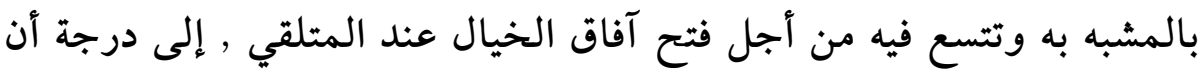

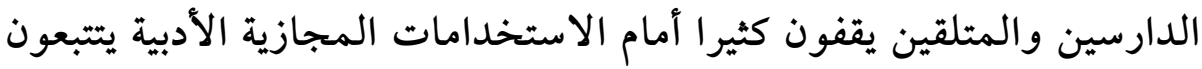

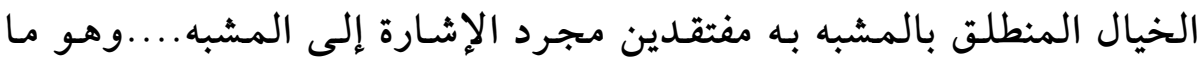

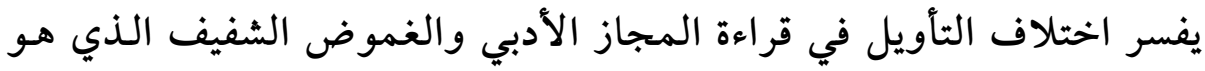

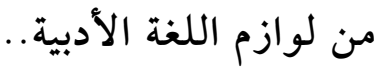


وإذا مـا نظرنا إلى معالجة البلاغة العربية في مصنفات البلاغيين

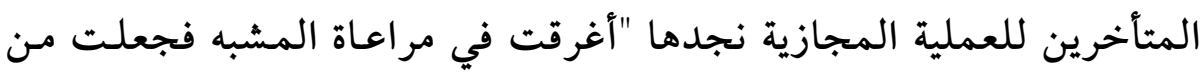

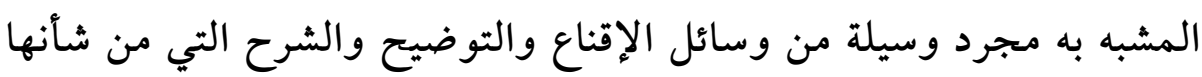

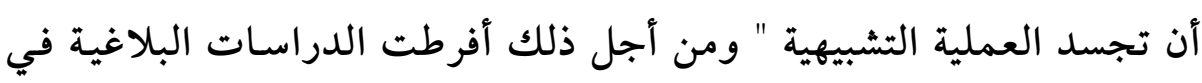

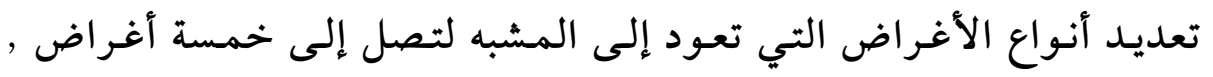

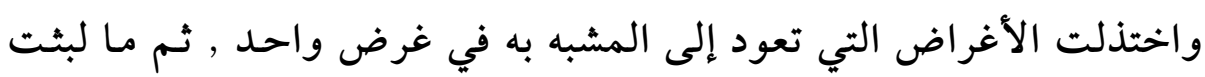

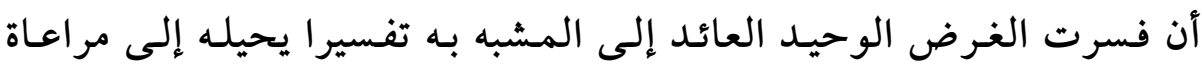

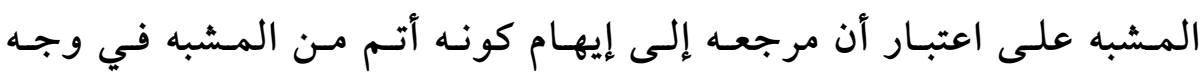
الشبه..وفيما يلي عرض لهذا التصنيف في مصنفات البلاغيين المتأخرين (•).

\section{تصنيف البلاغيين التقأخرين لوجوه الغرض من التشبيه}

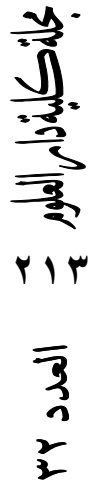

$$
\begin{aligned}
& \text { (أ) يعود إلى المشبه: } \\
& \text { ا - لبيان حاله. }
\end{aligned}
$$

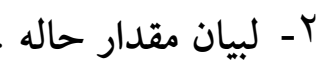

$$
\begin{aligned}
& \text { r- لبيان إمكان وجوده. } \\
& \text { ـ - لتقوية شأنه مع السامع. } \\
& \text { هـ - لإبرازه إلى السامع. } \\
& \text { (ب) يعود إلى المشبه به: }
\end{aligned}
$$

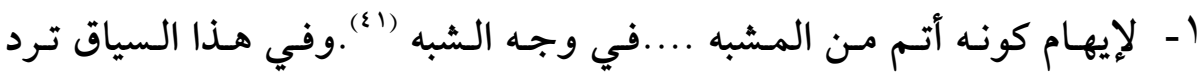

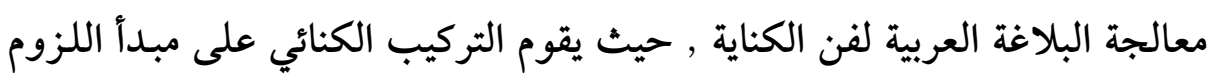

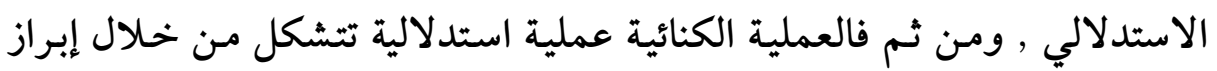

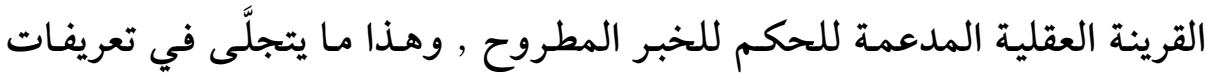

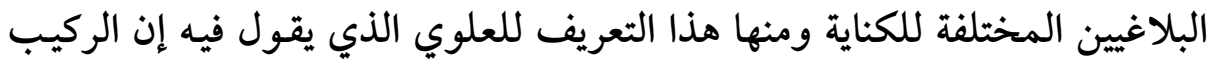

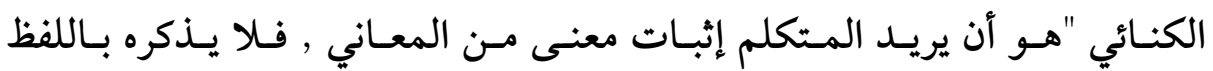

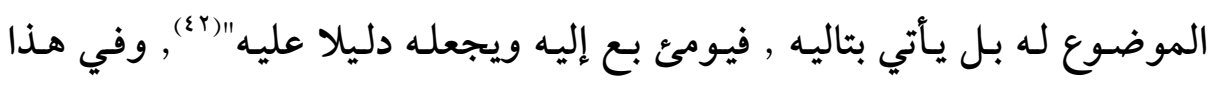




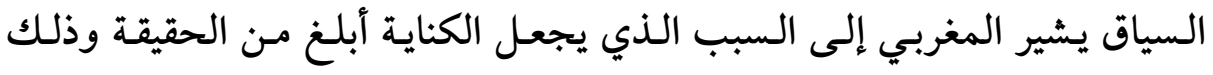

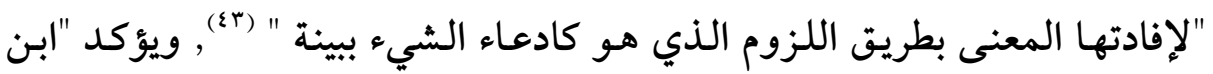

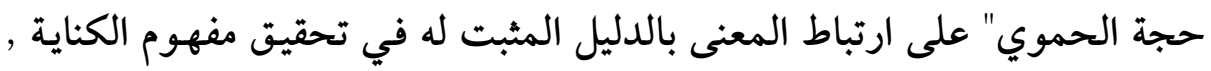

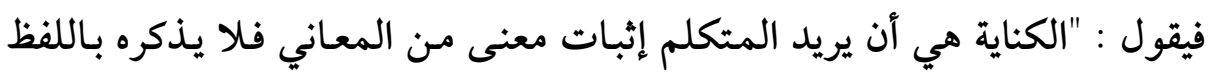
الموضوع له في اللغة ولكن يجيء إلى معنى هو ردفه في الوجود , فيومئ إليه ويجعله دليلا عليه.....كقول الشاعر:

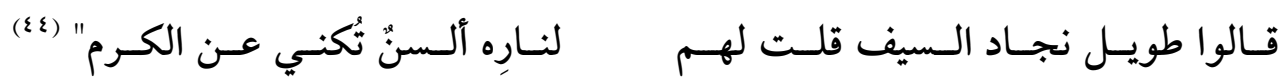

وعلى هذا يكون وصف الرجل بأنه فارع الطول يقصر في الاحتجاج

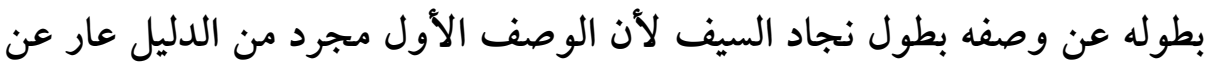

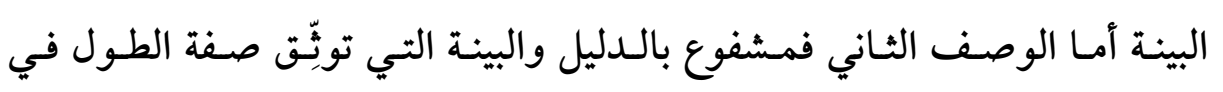

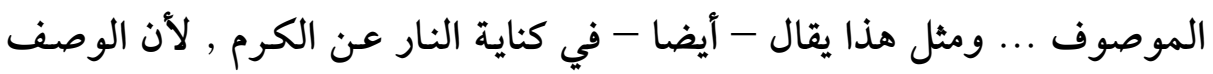

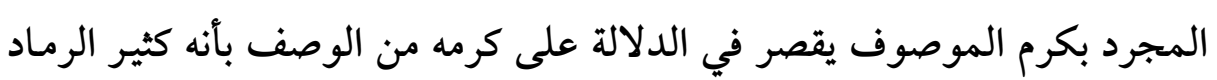

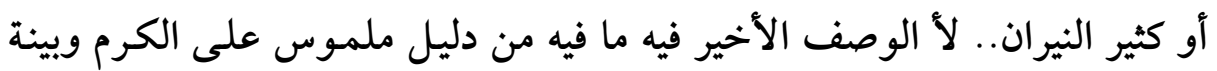

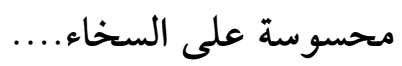

وما يقال في شأن الكناية يقال في أمر المجاز المرسل , حيث يهيمن مبدأ

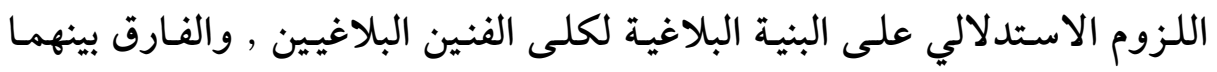

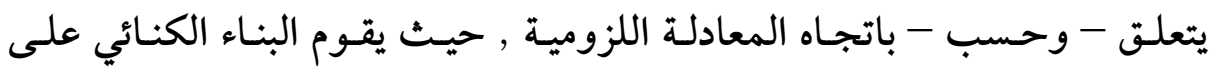
الانتقال من اللازم إلى الملزوم كما إذا قيل : فلان طويل النجاد كناية عن طول

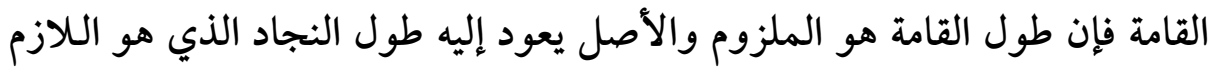

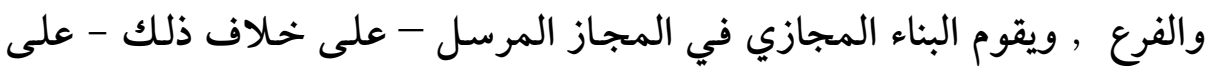
الانتقال من الملزوم إلى اللازم كما إذا استعمل لفظ الغيث لينتقل من تصور معناء الفرداه الذي هو الملزوم إلى معنى النبات الذي هو اللازم .. (ه). 
هكذا تقتضي الحقيقة العلمية التنويه إلى إن هنالك ارتباطا مشهودا بين

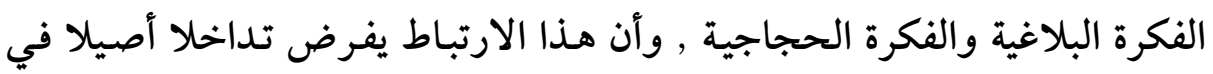

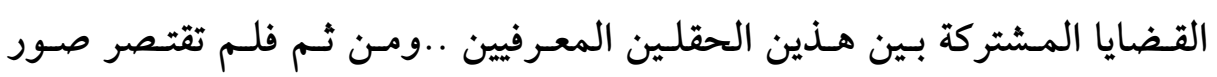
التداخل بين غايتي البلاغة والحجاج على مصنفات البلاغيين المتأخرين , بل ثمة من المتقدمين من أفصح عن القيمة الحجاجية لعدد من فنون البلاغة , مثل عبد بـديد القاهر الجرجاني في تناوله للتمثيل والتخييل...وفيما يلي قراءة لمعالجة عبد القاهر

$$
\text { الجرجاني لهذين الفنين البلاغيين : }
$$

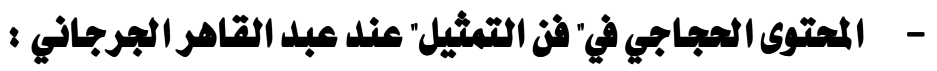

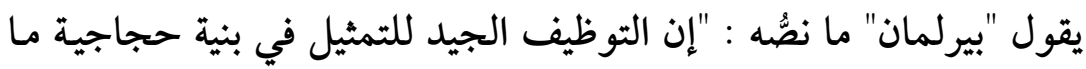

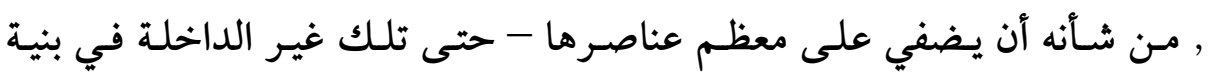

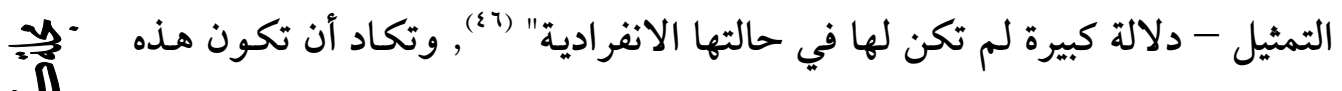

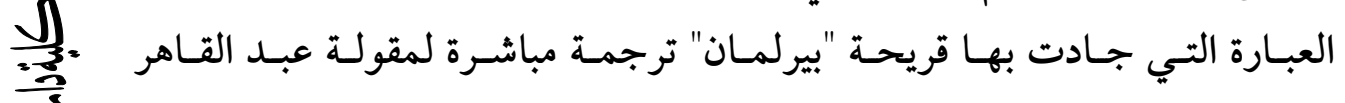
الجرجاني التي يزعم فيها أن فن التمثيل إذا ورد في سياق الحجاج "كان برهانه

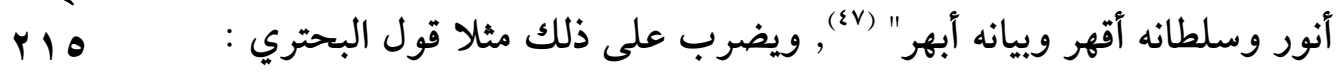
$\overline{3}$

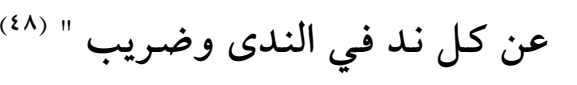

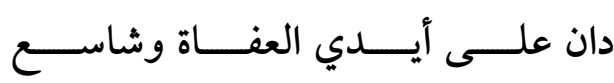

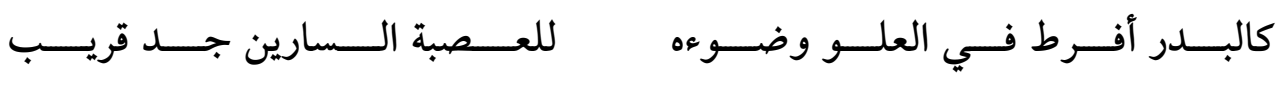

ثم يعلق على هذين البيتين بما يجلي تأثير القياس التمثيلي في إبراز

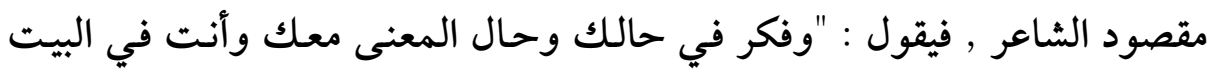

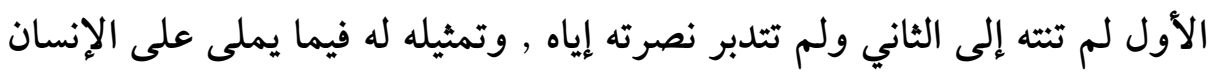

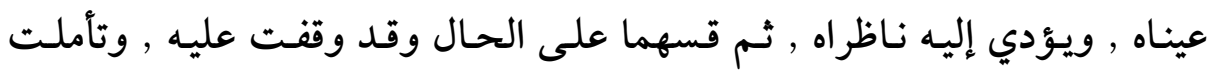

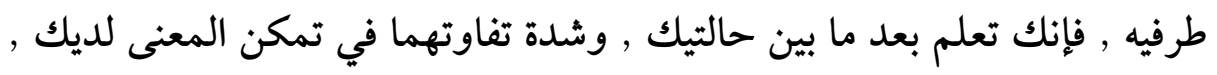
وتحببه إليك , وبيله في نفسك , وتوفيره لأنسك , وتحكم لي بالصدق فيما قلت,

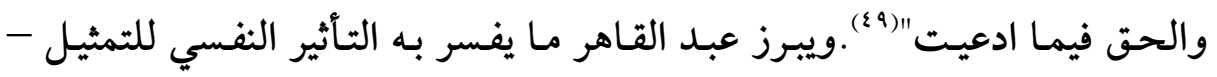

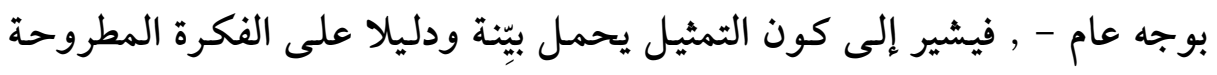


مما يمثل حجة مقنعة عند من يتلقى الخبر , وبأن المثل الذي يحمل دليلا على الفي

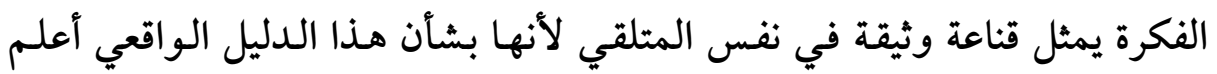

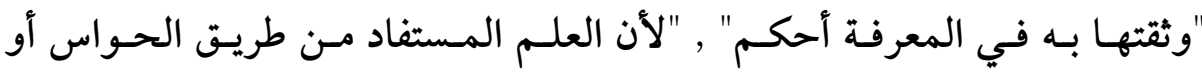

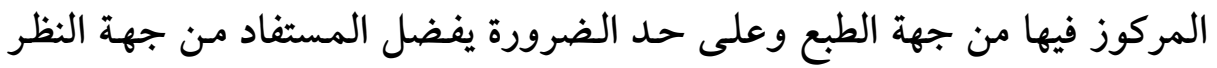

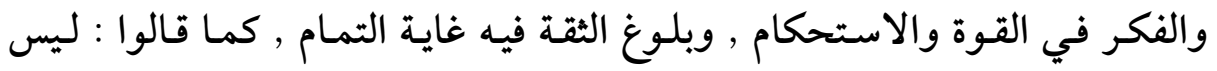

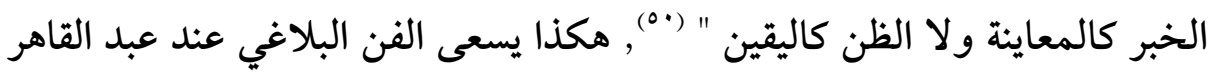

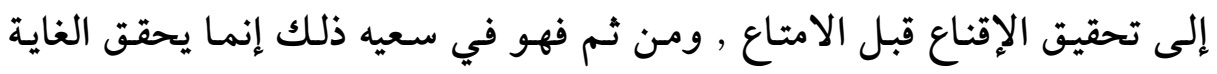

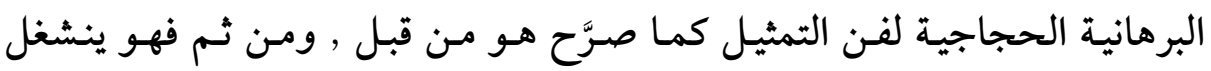

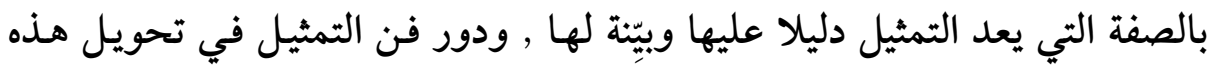

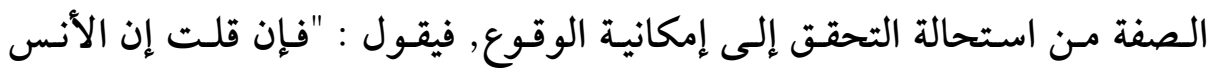

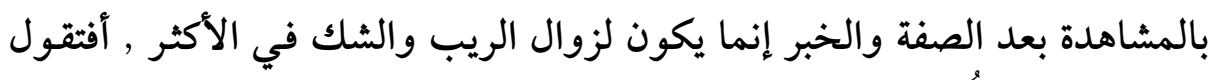

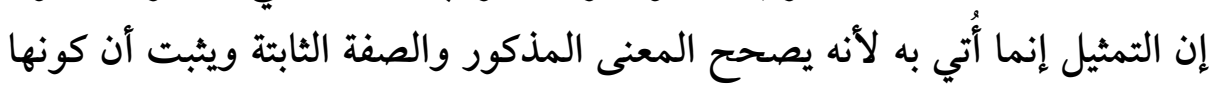

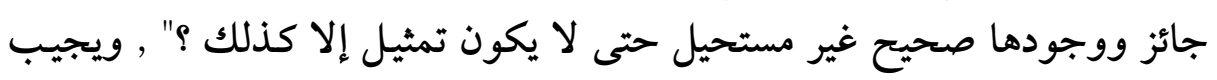

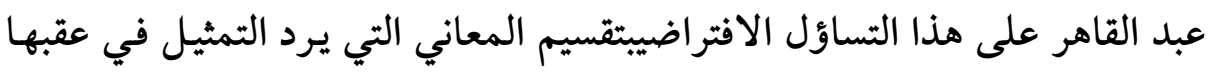

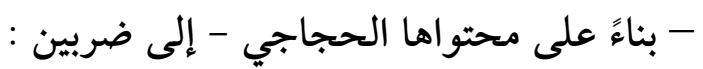

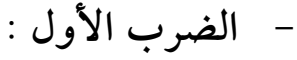

"غريب بديع يمكن أن يخالَف فيه ويدَّعى امتناعه واستحالة وجوده ر وذلك نحو

فــإن المسـك بعــض دم الغـــزال

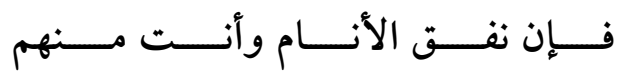
وذلك أنه أراد أنه فـاق الأنام وفاتهم إلى حـد بطل معهد أن يكسون بينه

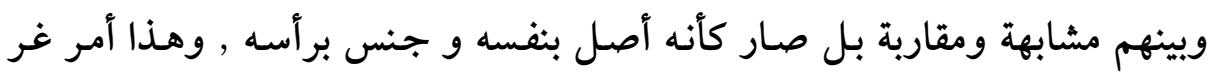
يب وهو أن يتناهى بعض أجزاء الجنس في الفضائل الخاصة به إلى أن يصير كأنه

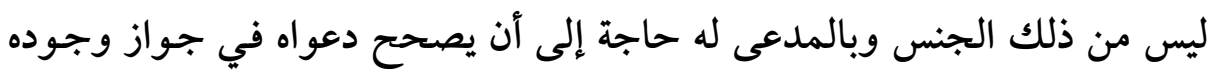

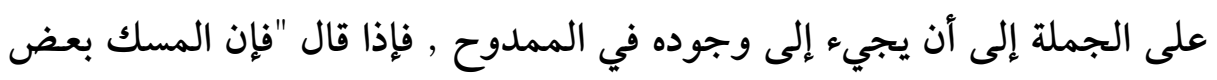

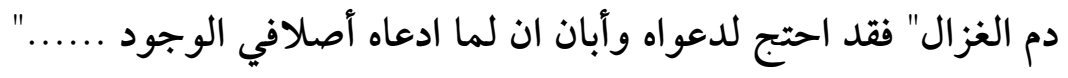




$$
\text { - }
$$

"ألا يكون المعنى الممثل غريبا نادرا يُحتاج في دعوى كونه على الجملة إلى بينة

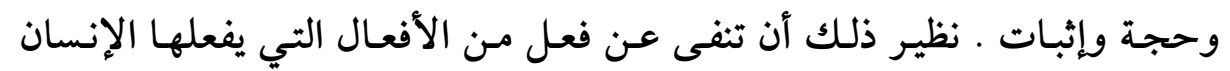

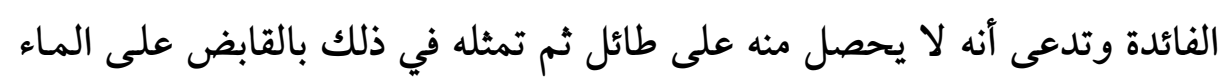
والراقم فيه , فالذي مثلت ليس بمنكر مستبدع إذ لا ينكر خطاً الإنسان في فعله أو بأ ظنه وأمله وطلبه , ألا ترى أن المغزى من قوله : فأصبحت من ليلى الغداة كقابض على الماء خانته فروج الأصابع أنه قد خاب في ظنه أنه قد يتمتع بها ويُسعَد بوصلها , وليس بمنكر ولا الا

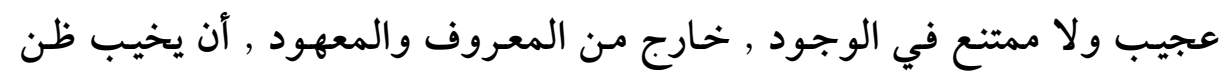

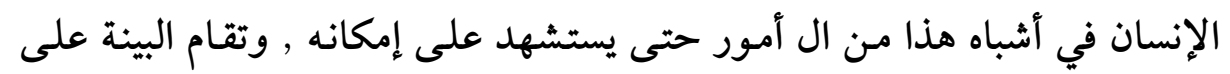

\section{المحتوى الحجاجي في "فز التخييل" عند عبد القاهر الجرجاني :}

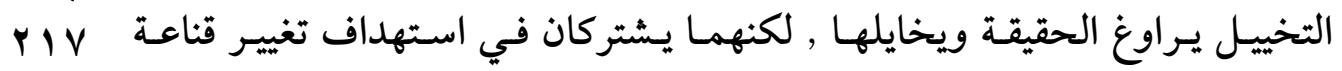

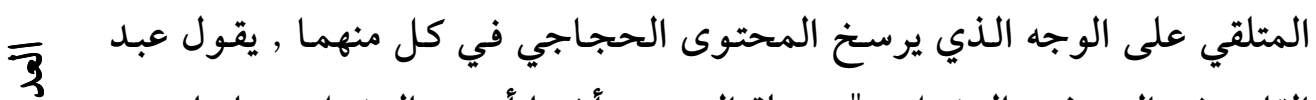

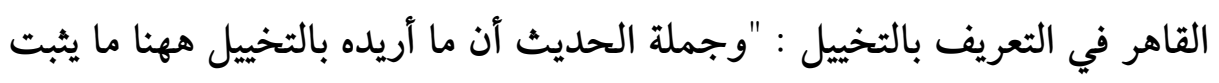
فيه الشاعر أمرا هو غير ثابت أصلا ويدعي دعوى لا طريق إلى تحصيلها ويقول

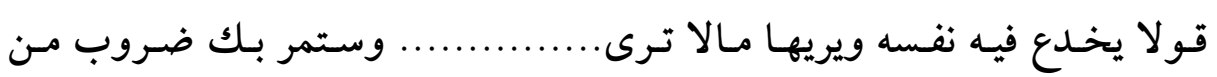
التخييل هي أظهر أمرا في البعد عن الحقيقة وأكشف وجها في أنه خداع للعقل

$$
\text { وضرب من التزويق " (or). }
$$

وتتوازي هـذه القسمة بين التمثيل (الحجاج المتفق مع الحقيقـة والواقع)

والتخييل (الحجاج المجانب للحقيقة والواقع) مع قسمة علمـاء الحجاج قديما

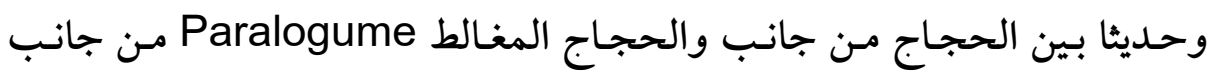
آخر , وقد أفرد أرسطو لهذا النوع الحجاجي جزءا كبيرا من مصنفه "التبكيتات 
"Fallacies" السوفسطائية" , وكان من اهتم به حديثا "هامبلين" • لو ام في كتابه

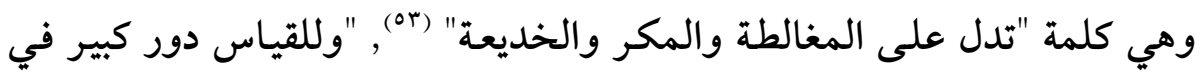
هذه الصناعة عند من يحزق استعماله , لأن لمقدماته صورا عديدة , فمنها مثلا ما

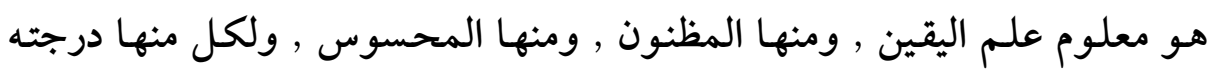

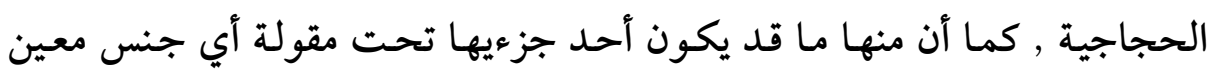

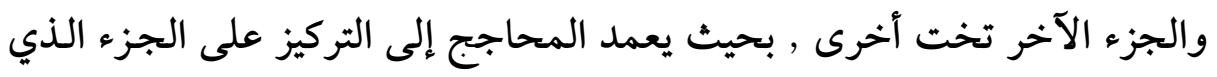

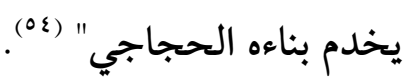
ومن ثم فعبد القاهر يضع المعاني التخييلية كمعادل عكسي أمام المعاني العقلية

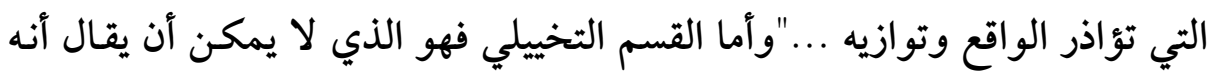

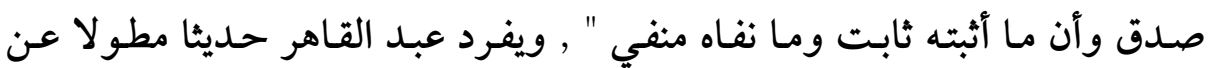
أبواب الحجاج التخييلي , فيذكر أنه يرد على صور متعددة على الوجه وابثه التالي.

\section{القسم الأول :}

"ما يجيء مصنوعا قد تُلُطِفَفَ فيه واستعين عليه بالرفق والحذق , حتى أعطي

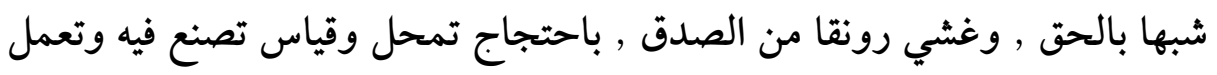

فالسيل حرب للمكان العالي

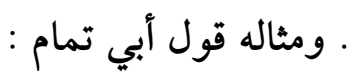

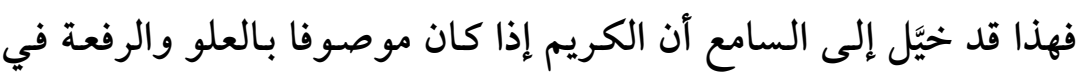

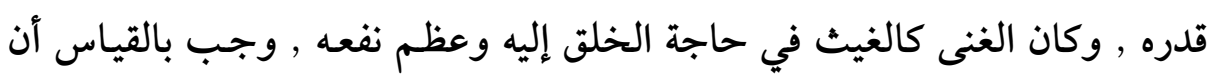

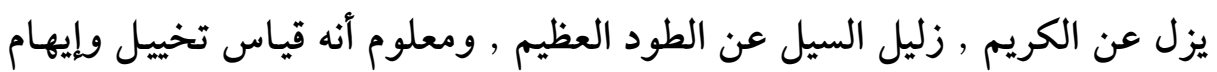

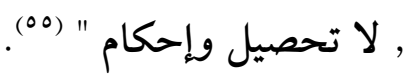




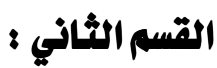

" ومن ذلك صنيعهم إذا أرادوا تفضيل شيء أو نقصه , ومدحه أو ذمه ,

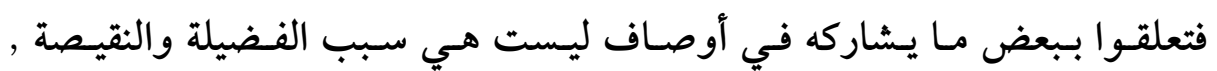

وظواهر أمور لا تصحح ما قصدوه من التهجين والتزيين على الحقيقة , كما تراه في باب الشيب والشباب , كقول البحتري :

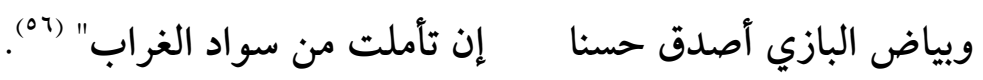

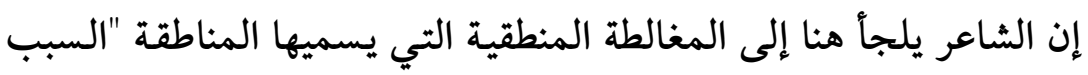

الزائف" FALSE COUSE, ويقصدون بها الخلط المقصود بين المعية

والسبية أو جعل مجرد الارتباط بين حدثين دليلا على أن أحدهما سبب للآخر ,

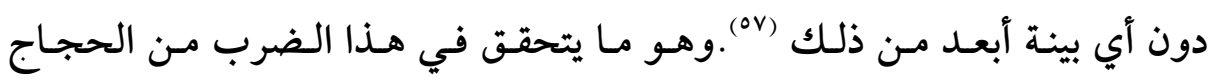

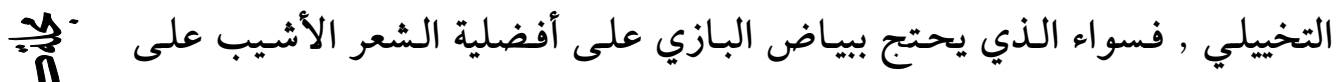

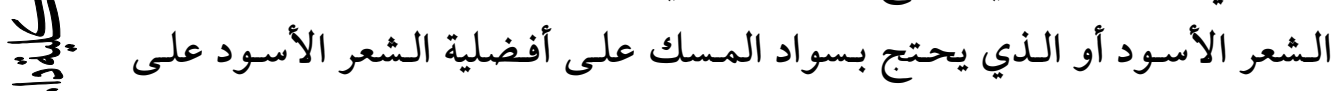

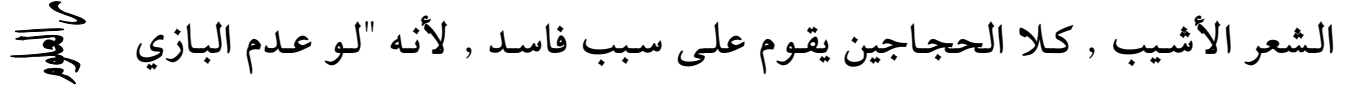

فضيلة أنه جارح وأنه من عتيق الطير لم تجد لبياضه الحسن الذي تراه , ولم يكن

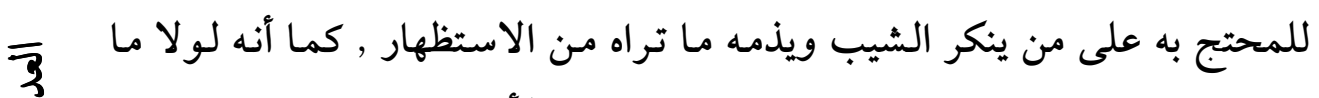
يهدى إليك مـن المسك من رياه التي تنطلع إليها الأرواح , وتهش لها لهن النفوس وترتاح , لضعفت حجة المتعلق به في تفضيل الشباب" (هـ).

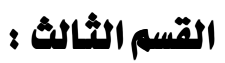

ويقصد بـه ادعاء الشاعر أن صفة مـا مـن الصفات لمم توجـد في الشيء

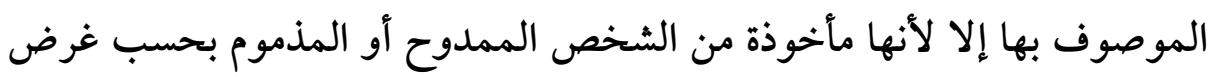

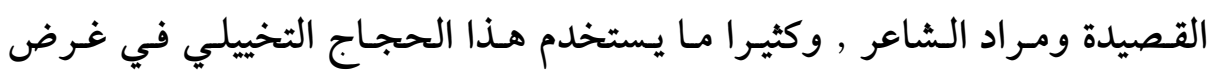
المدح "مثل قولهم إن الشمس تستعير منه النور وتستفيد أو تتعلم منه الإشـراق

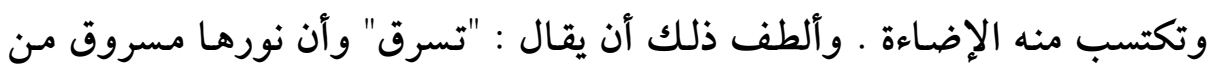

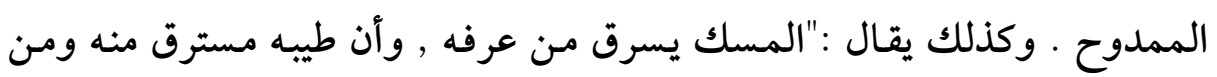

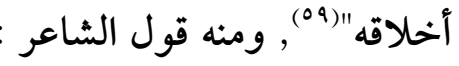




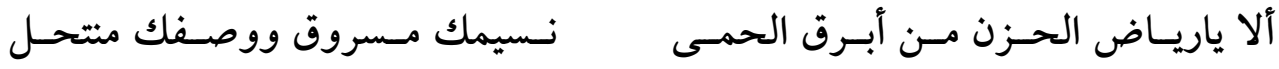

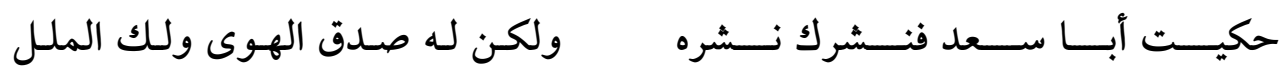

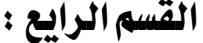

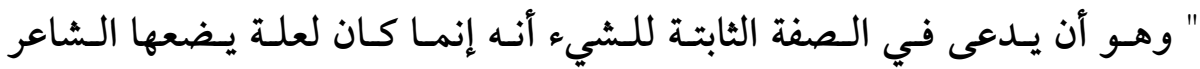

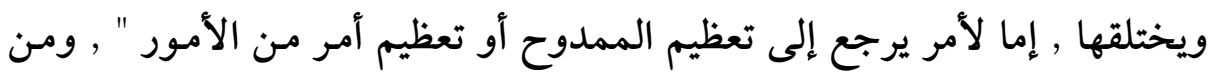

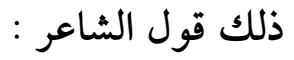

لو لم لم تكن نية الجوزاء خدمته لما رأيت عليها عقد منتطقِ

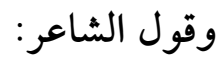

لم تحك نائلك السحاب وإنما حمت به فصبيبها الرخصاء

وما ريح الرياض لها ولكن كساها دفنهم في الأرض طيبا :

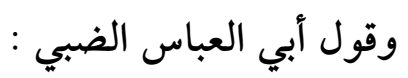

ق وإن ســــكنت إلـــــى العنـــــاق

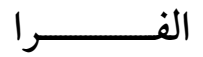

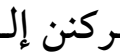

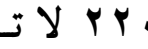

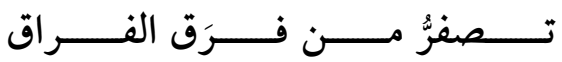

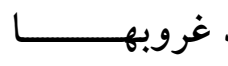

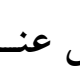
فال

وهذا القسم يندرج تحت ما يسمَّى "التعليل التخييلي" (·7), وهو ما سيأتي الحديث عنه في الفصل الخاص بفن التعليل وهو الفن الذي يعتد الحجاج فيه

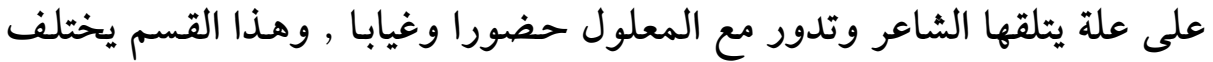
عن سائر أنواع الحجاج التخييلي الذي منه قول الشاعر:

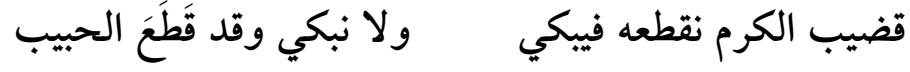
أو قول الصولي من لطيف هذا الجنس الحجاجي:

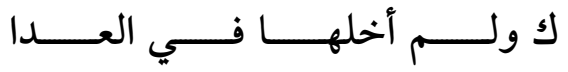

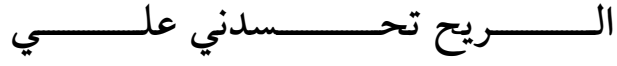

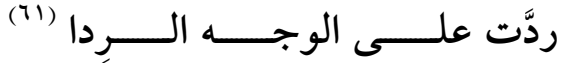
ت بقتبلـ 
(ب) - المصطاحات الإيقامية ( فتوز البليع ) ؛

للفنـون البلاغيـة القائمسة على الإيقـاع خلابـة تأسـر الأذن , حتـى يلـذها الاستماع للفكرة المطروحة , حيث تنتقل اللذة الحاصلة من الإيقاع والجرس إلى لي المحتوى والمضمون , ولهذا كان الشعر أشبه بالسحر في تغيير القناعات وتبديل الأفكار , وهو ما يلخصه الشاعر في قوله:

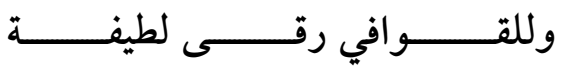

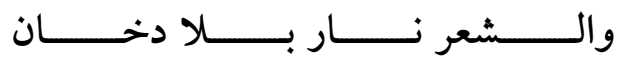

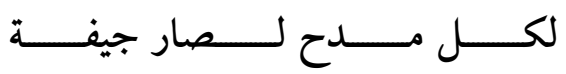

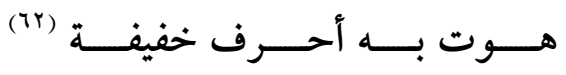

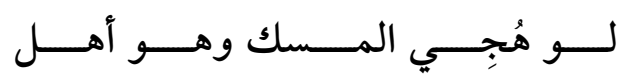

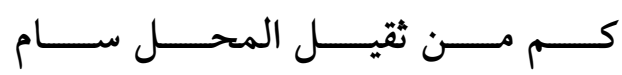

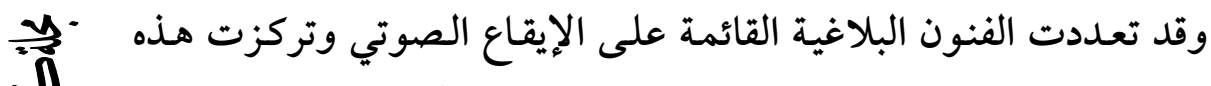

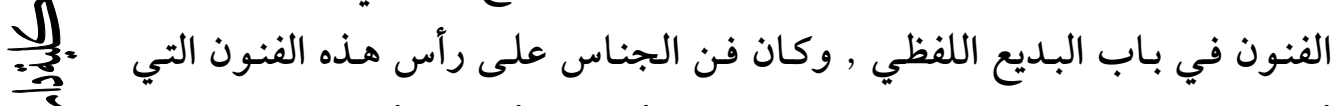

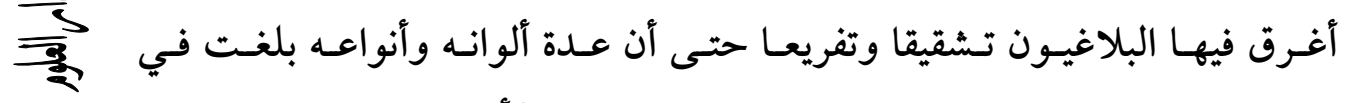

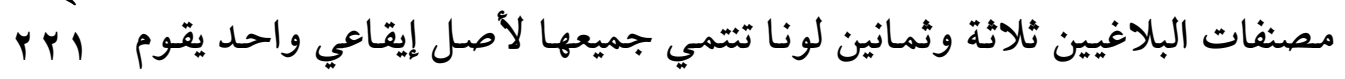

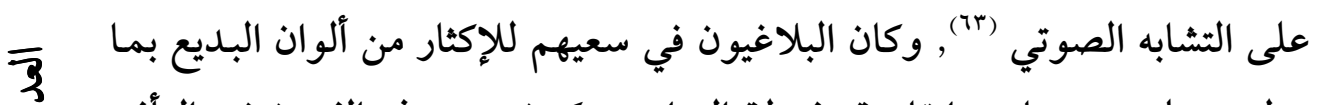
تنطوي عليه من عناصر إيقاعية مفرطة الثراء يدركون دور هذه الفنون في الثأثير

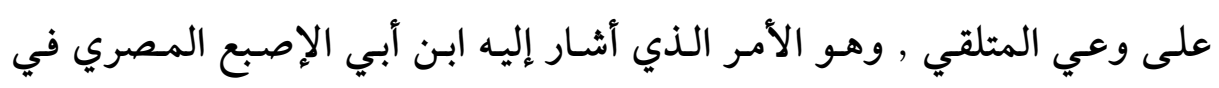

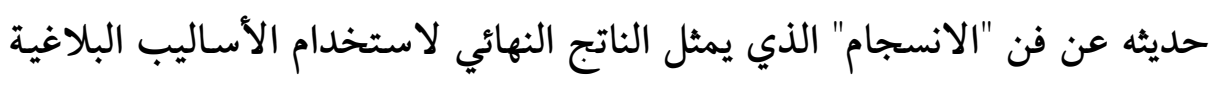
القائمة على الإيقاع , حين عرفه فقال :" هو أن يأتي الكلام متحدرا كتحدر الماء

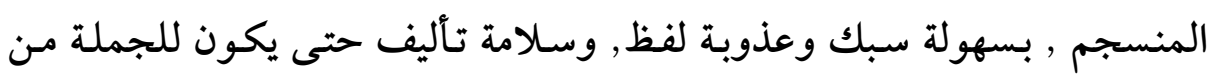

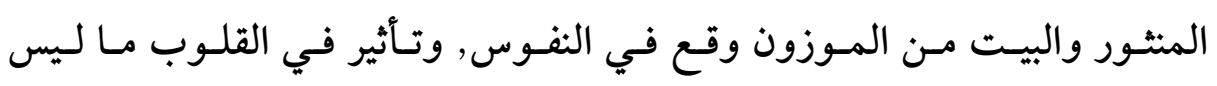

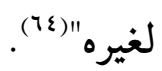

ولا تقف المضامين الحجاجية في تجلياتها الإيقاعية عند البديع اللفظي بل

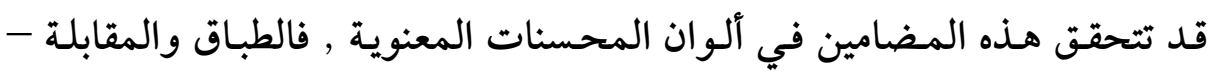
مثلا - يحدثان قدرا هائلا من الإيقاع المعنوي الذي من شأنه أن يحققالتجسيد 
للفكرة المطروحة وفقا للمسلمة التي تقول : (وبضدها تتميز الأشياء ) , وقد فطن

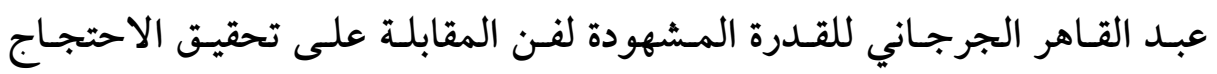

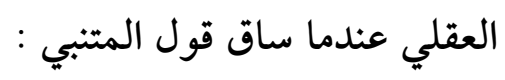

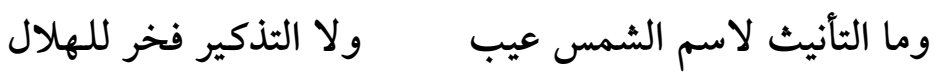

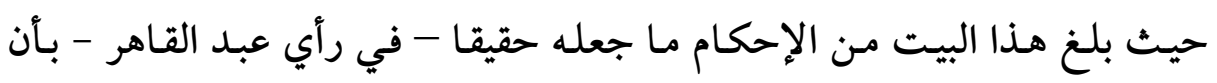

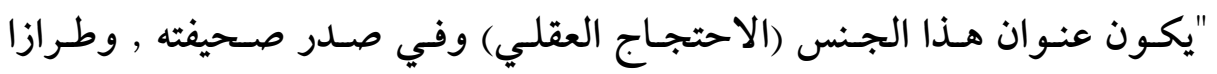

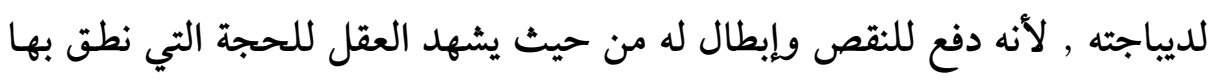
بالصحة "(70). وتنطوي الفنون البديعية على آلية تكرارية تجمع بين كل فنون البديع العربي

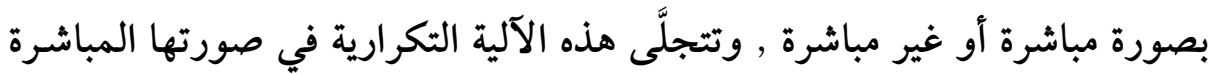

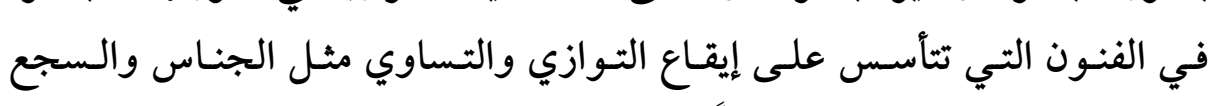

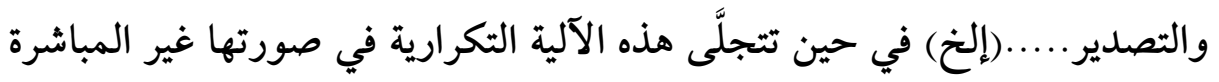

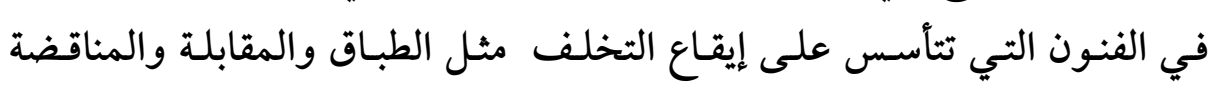

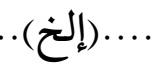

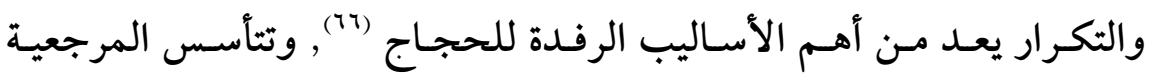

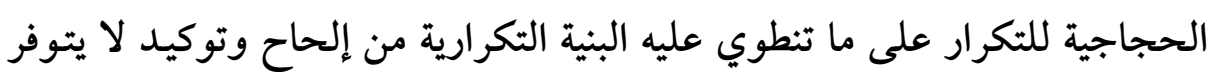

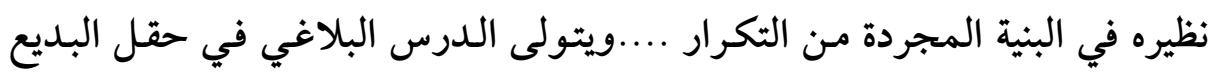

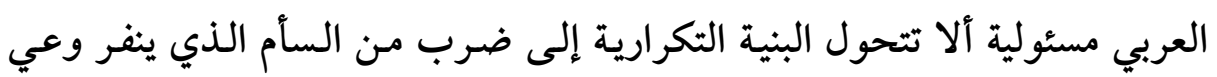

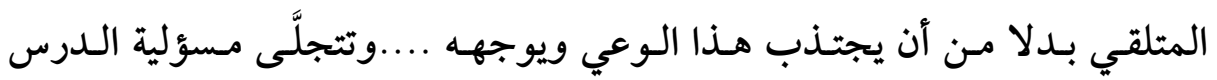

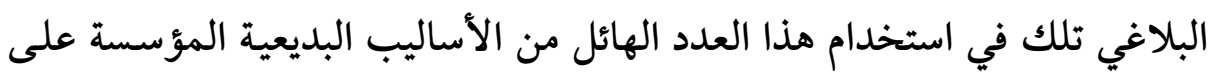

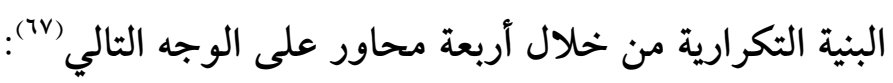
المحور الأول (من محاور البديع الذي يعتمد التكرار في إنتاج دلالته) :

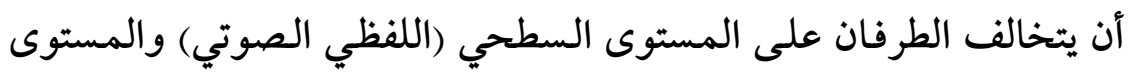

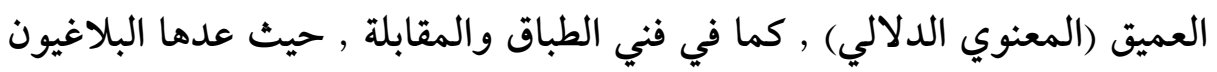


من الأساليب التي تحقق التناسب على حد تعبير التنوخي أو التكافؤ على حد تسمية العلوي وهو ما يسوغ "إضافة هذه البنية البديعية إلى دائرة التكرار" حيث يحمل الطباق والمقابلة مفهوم التساوي بين كِفتين متوازنتين , حتى أنه إذا اختلت إحدى الكفتين انمحت المقابلة وانتفى الطباق..

-

"أن يتوافق الطرفان على المستوى السطحي والمستوى العميق , ويضم آربع بنى هي تشابه الأطراف والترديد زرد الأعجاز على الصدور والمجاورة ."

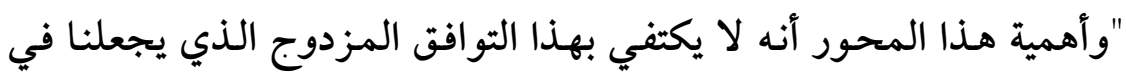
مواجهة تكراريـة مباشـرة , بـل إنه يضيف إليها ملاحظة البعـد المكاني للـدوال , وتنسيقها على نحو معين يساعد على توافق حركة السطح مع حركة العمق , وهـو توافق بعيد الأثر في إنتاج الدلالة....

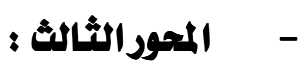

هو الذي يعتمد التوافق السطحي والتخالف في العمق , ويضم ست بنى , هي :

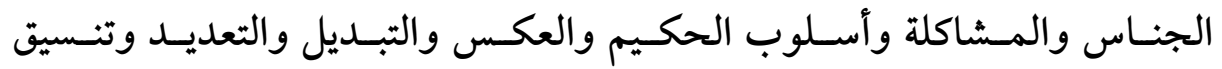

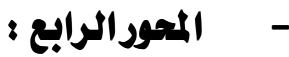

هو الذي يعتمد التخالف في المستوى السطحي والتوافق في المستوى العميق , ويتمثل في عدد من الفنون منها مراعاة النظير والإرصاد والتذييل وتأكيد المـدح بما يشبه الذم وتأكيد الذم بما يشبه المدح والالتفات (1^). ( ) أسلوب الاستفهام والتساؤلات الحجاجية : اهتم "ماير" بالتساؤل والمساءلة , وتقصَّى دورهما في الفكر الإنساني منذ سقراط وأفلاطون وأرسطو وانتهى إلى "إن الفلسفة القديمة لم تعن بما فيه الكفاية بالتساؤل" , وانطلـق مـن هـذه الفرضـية إلى استجاء إنلاء دور السؤال في الحجـاج والذي يشترط فيه - حتى يحقق حجاجا ناجعا - "أن يكون حاملا لطرافة فكرية 
يكون بحث المخاطَب عن دلالاتها مصدر متعة له من جهة , وتأييدا منه لمضمون

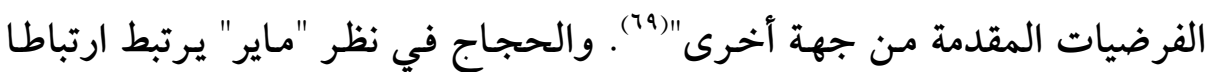

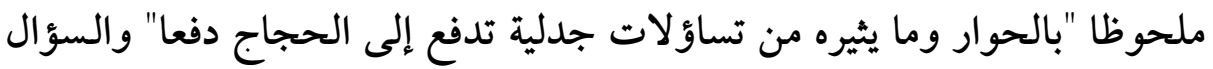

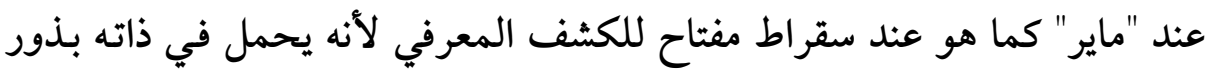

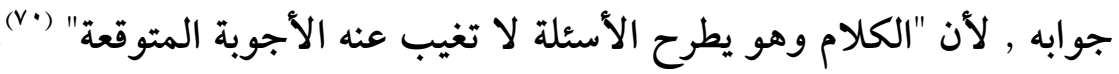

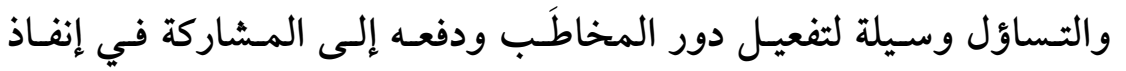
الحجة , وبناءً على هذا نستطيع أن نفرق بين مستويين من السؤال :

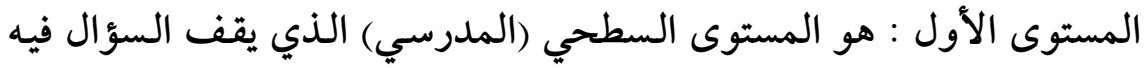

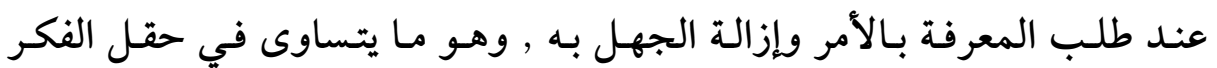
البلاغي مع "التزام الاستفهام بمقتضى الظاهر"

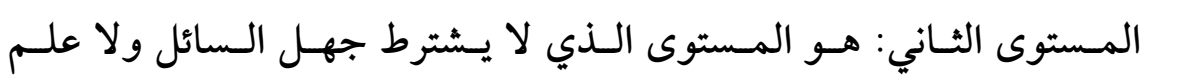

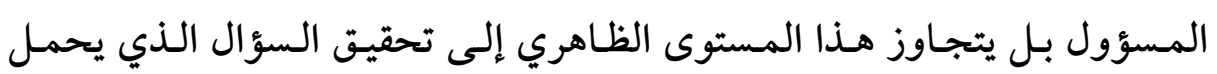

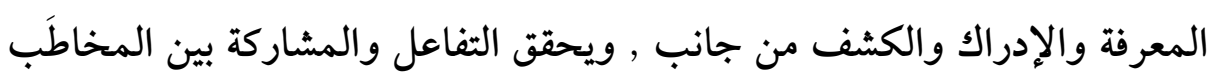

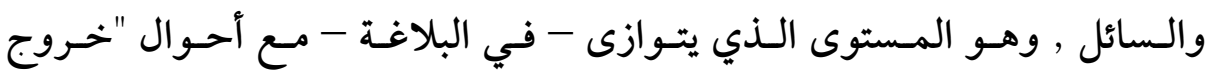
الاستفهام على مقتضى الظاهر" وقد أتاح النص القر آني للبلاغيين العرب اكتشاف العديد من تجليات هذا

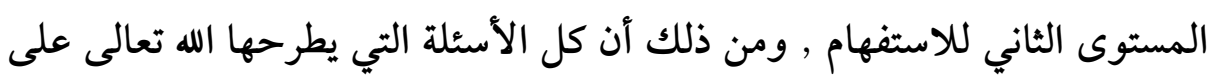

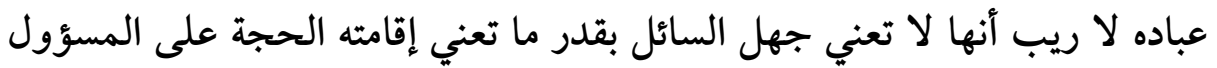

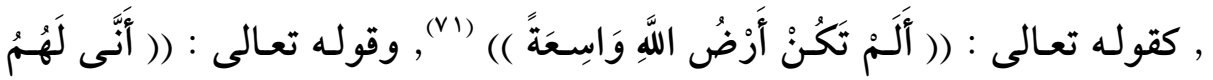

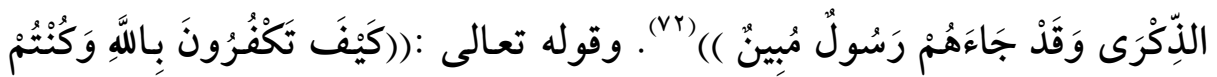

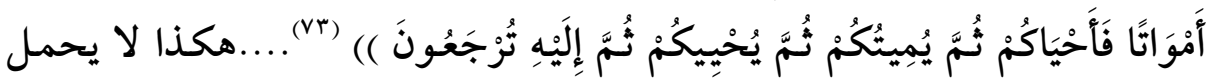

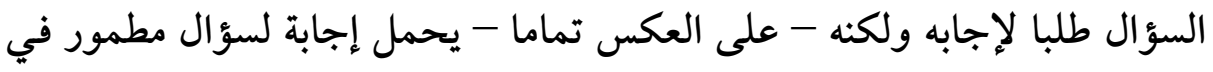
لاوعي المخاطب ... 
وقد يستهدف التساؤل القر آني تحقيق التفاعل من جانب المخاطب , كقوله

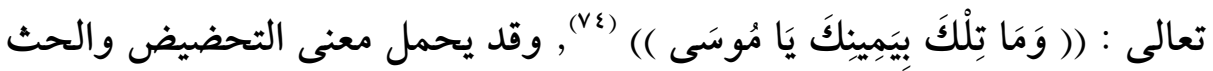

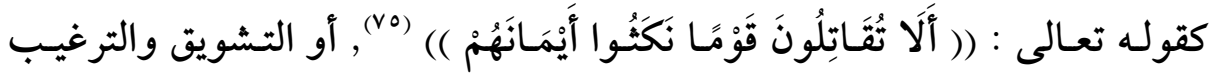

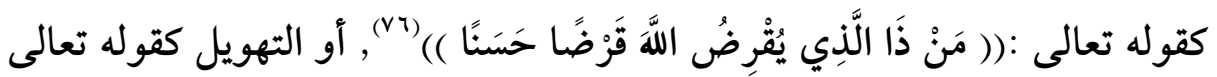

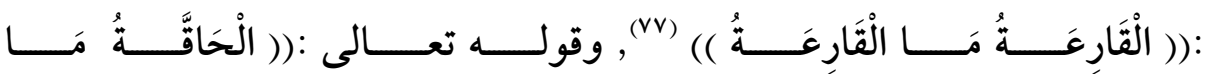

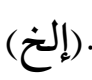

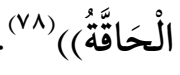

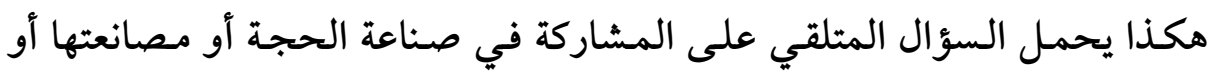

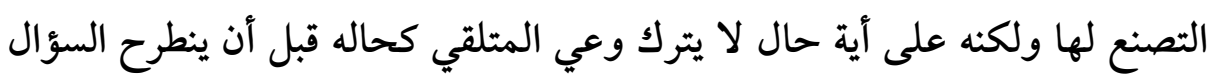
عليه .. والحقيقة أنـا إذا طبقنـا هـذا المـنهج على سـائر الأسـاليب الإنشائية في

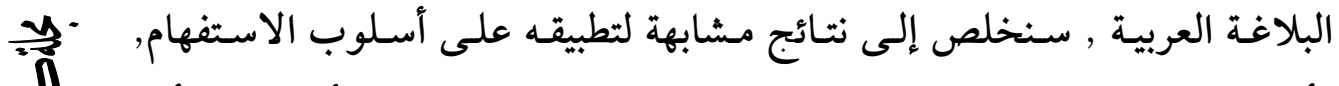

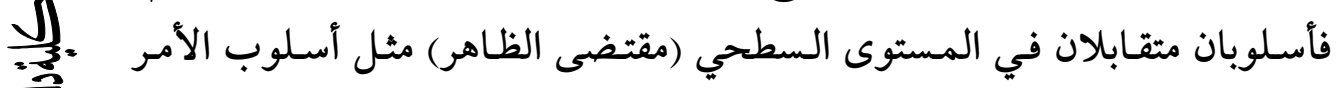

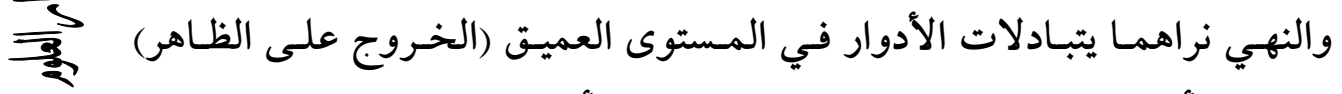

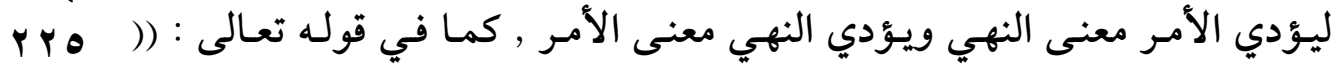

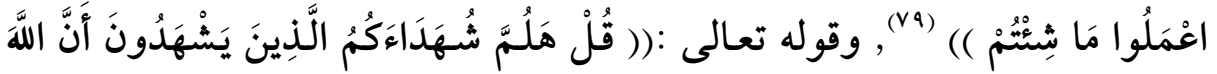

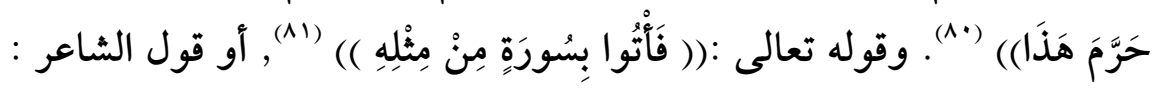

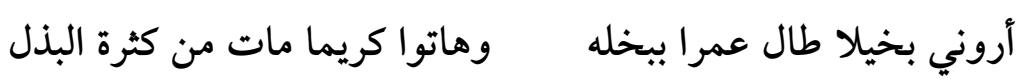

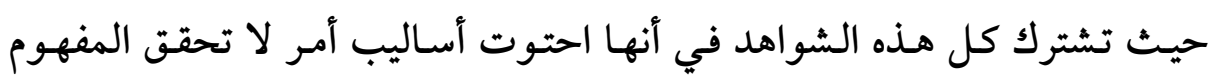

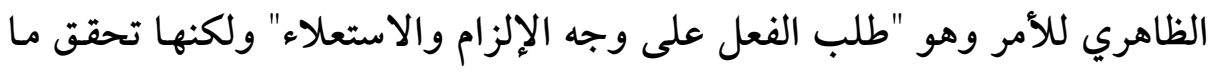

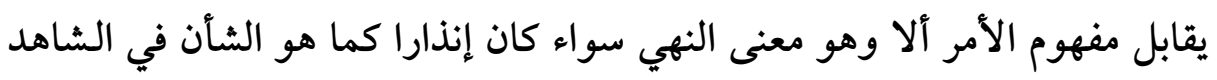

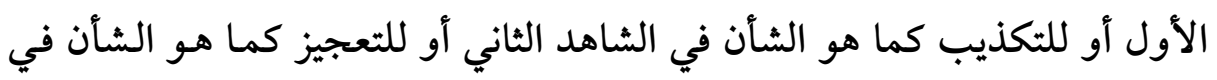

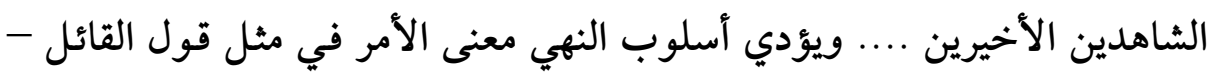
على سبيل التهديد - :"لا تمتثل أمري" . . .

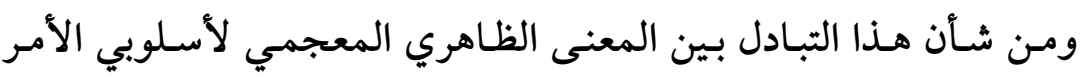

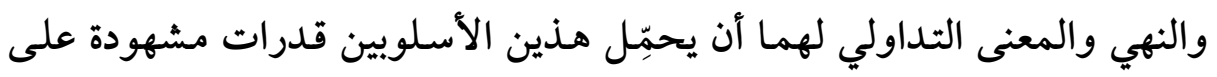


تحقيق الإقناع الحجاجي لما يوفِّه من إمكانية شحن العبارة بمضامين هائلة لا

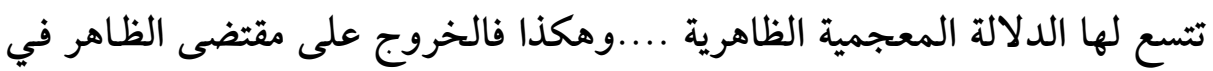

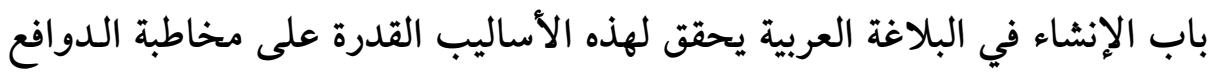

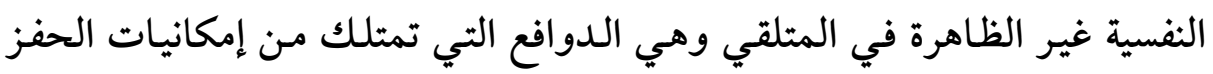
والشحذ ما تقصر عنه التعبيرات ذات الدلالة المباشرة.

ثانيا : المصطلحات ذات المنطلق العجاجي :

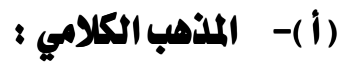

يعرفه ابن أبي الإصبع فيقول : "هو احتجاج المتكلم على المعنى المقصود المباهي

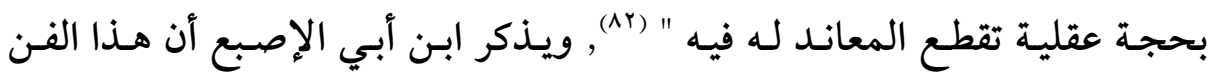

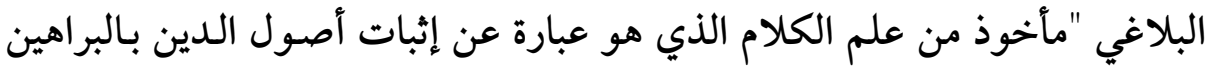

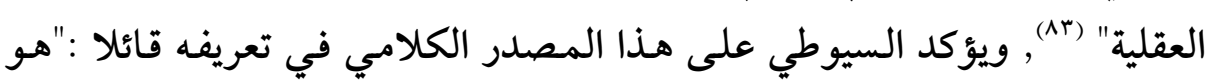

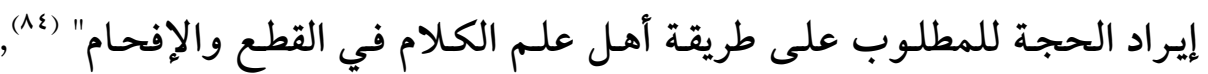

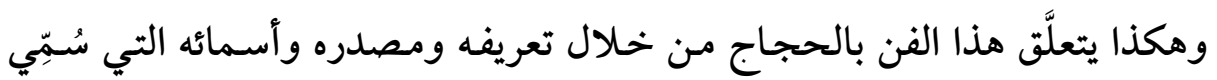

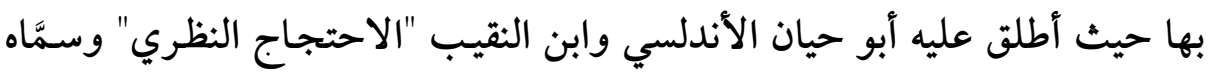

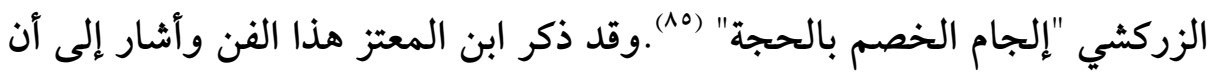

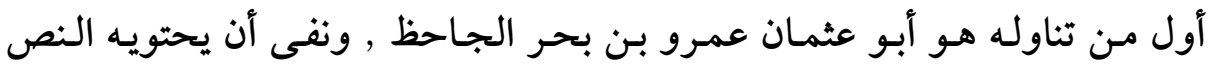

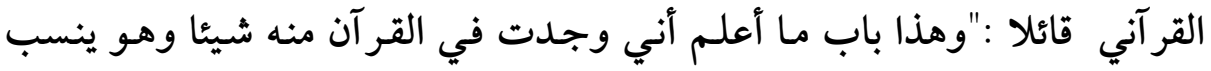

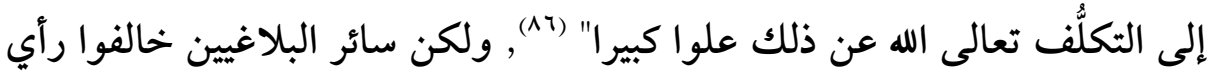

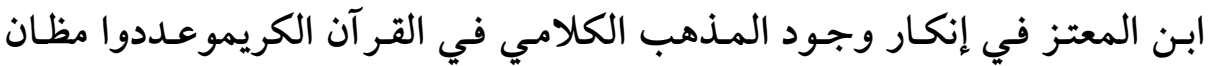

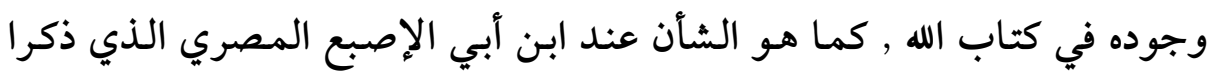

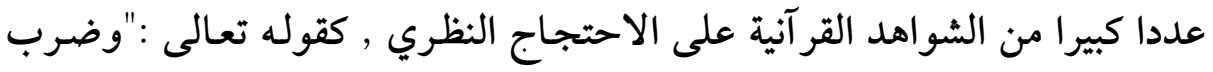

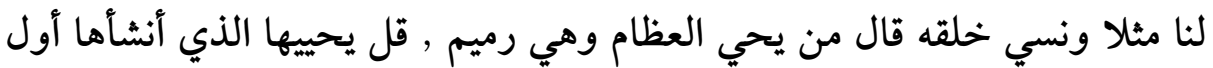

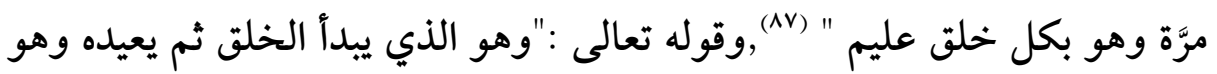

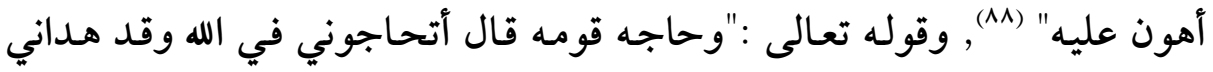


ولا أخاف ما تشركون به إلا أن يشاء ربي وسع ربي كل شيء علما أفلا تتذكرون

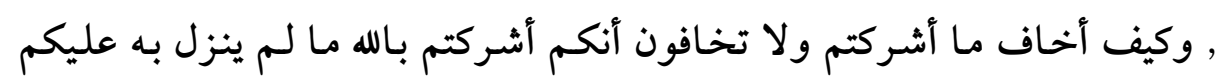

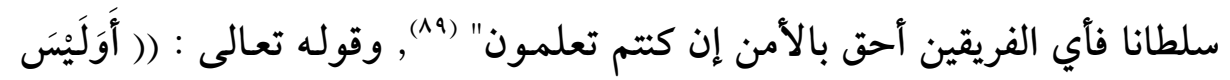

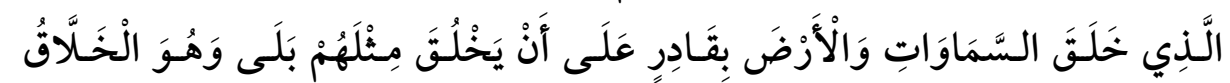

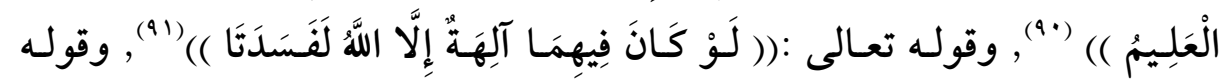

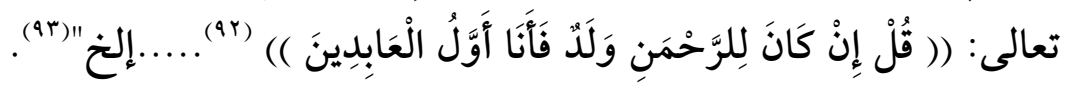

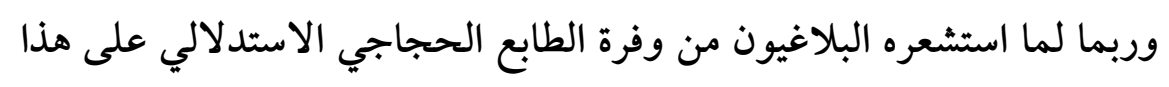

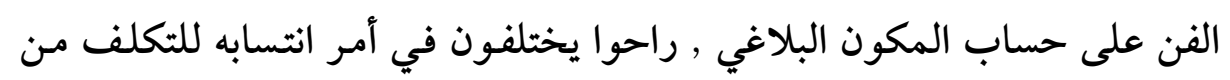

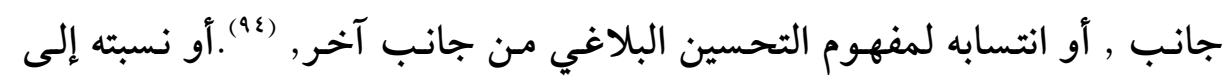

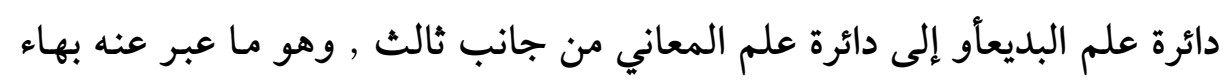

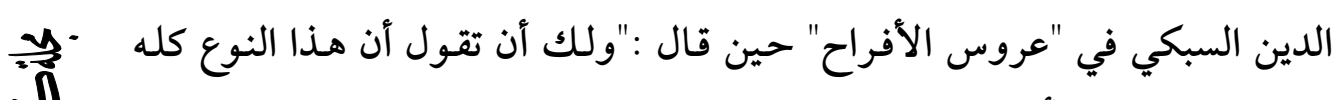

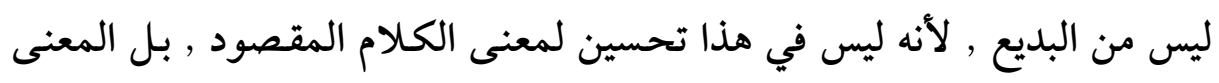

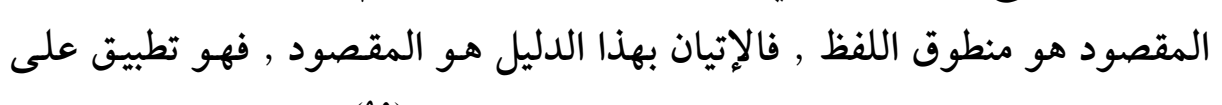

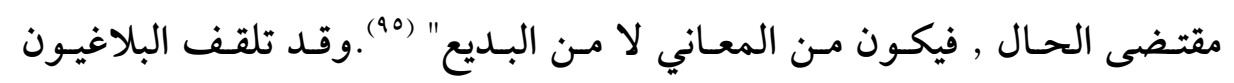

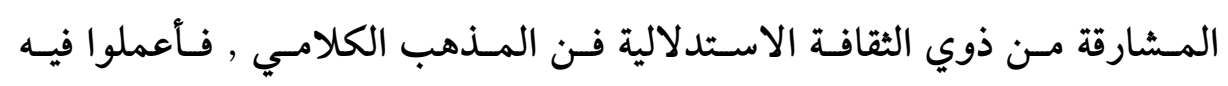

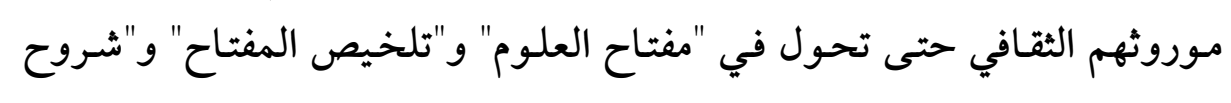

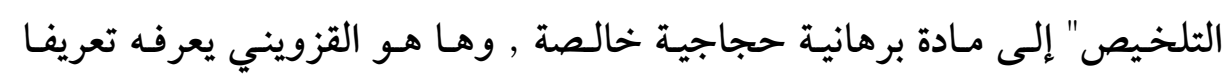

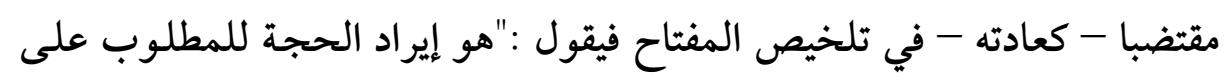

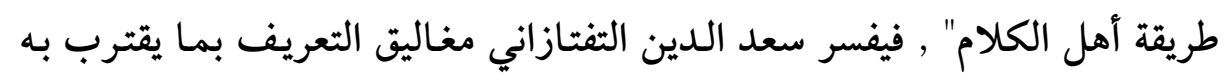

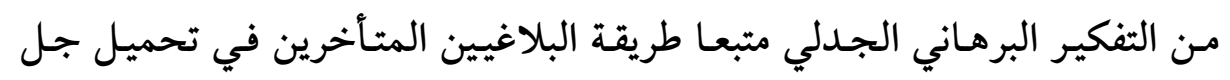

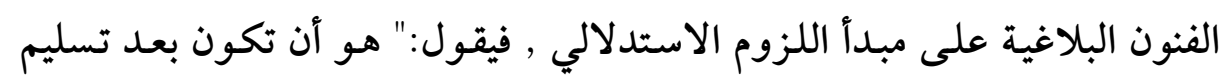

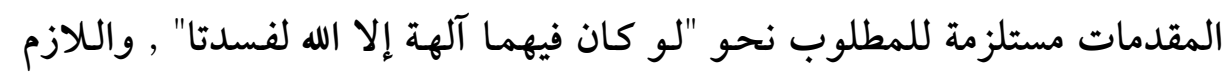

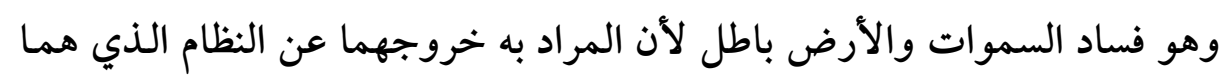

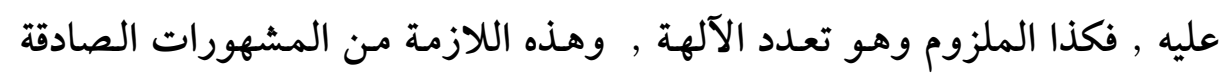

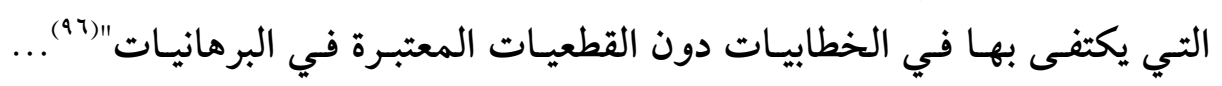


وهوفي هذا السياق يومئ إلى التفرقة التي أقامها البلاغيون - في إطار تحليلهم

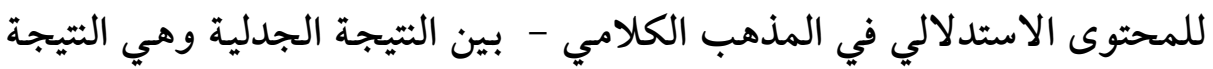
المحتملة الدلالة, والنتيجة البرهانية المنطقية وهي النتيجة قطعية الدلالة ل. . .

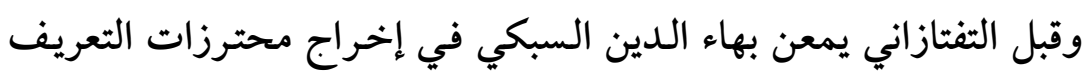

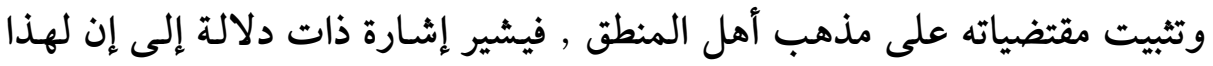

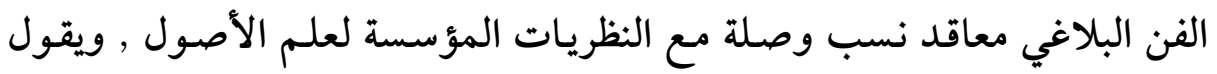

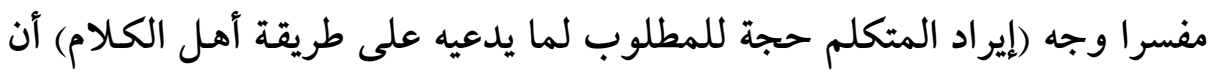

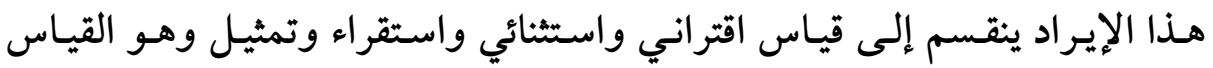

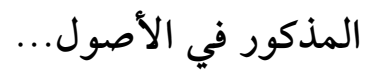

ويستغرق السبكي جهدا موفورا في تحرير العلاقة بين المذهب الكلامي

- من جانب - وعلمي المنطق ( الاستدلال ) والكلام - من جانب آحري آخر - فيقول

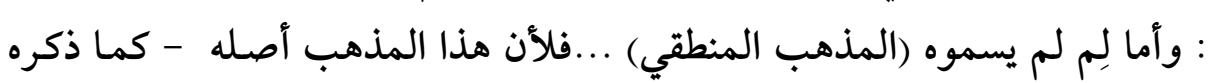

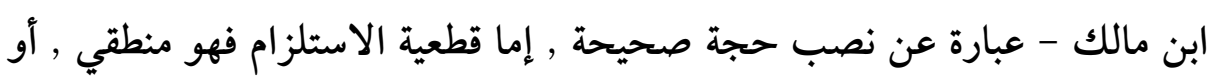

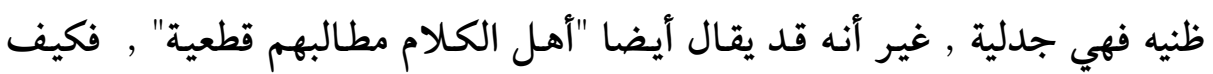

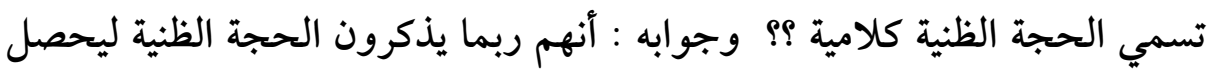

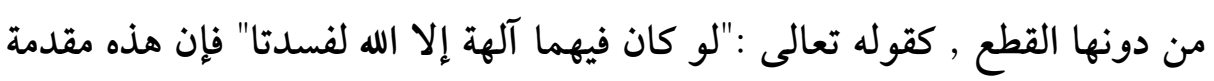

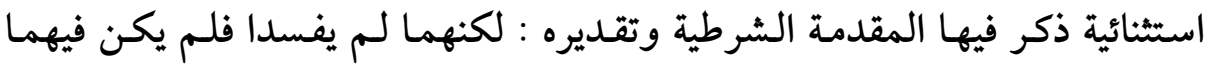

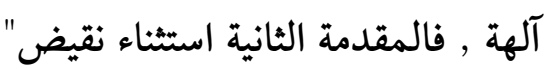
ويتلقف الدسوقي في حاشيته على شرح السعد هذه الإشارات الجدلية

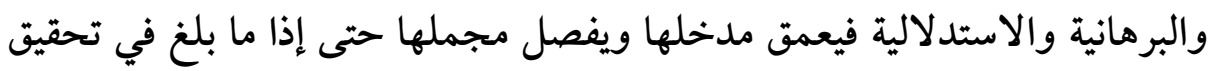

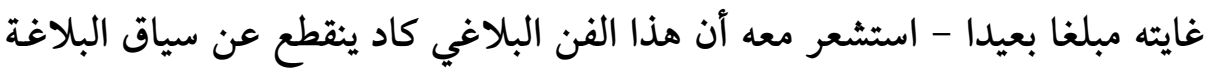

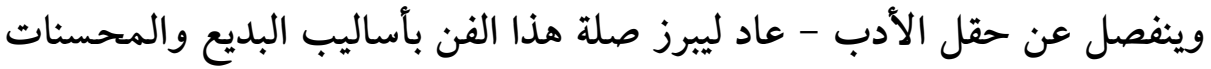

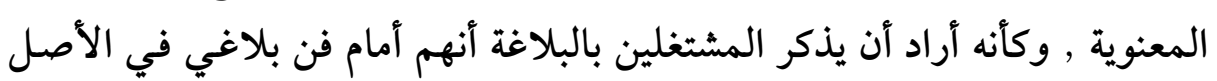

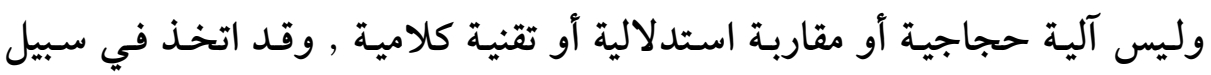


تحقيق ذلك طريقا وسطا لم ينف خلاله المنطلق الكلامي لهذا الفن وهو ما لا

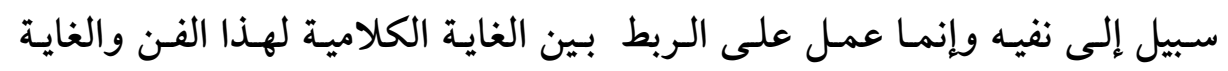

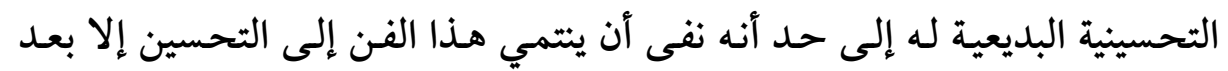

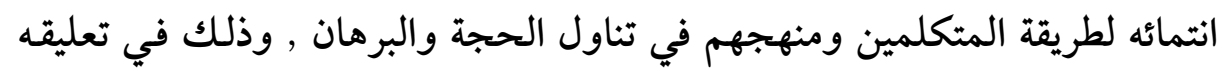

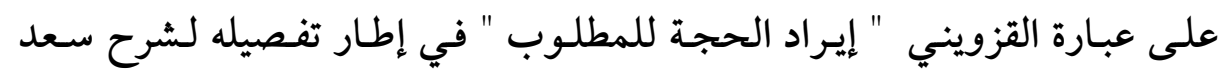

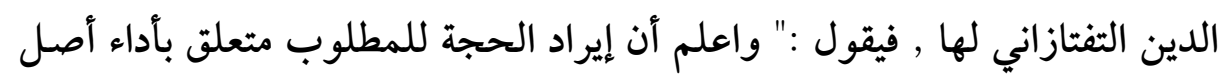

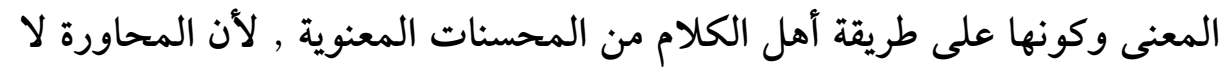

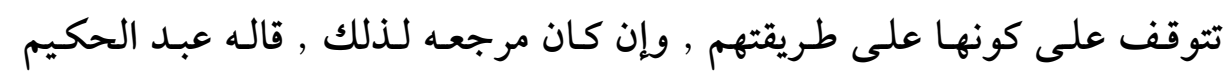

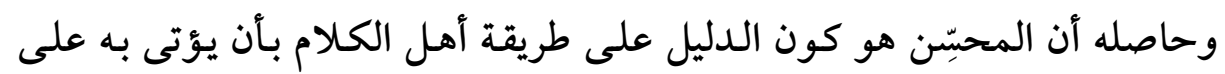

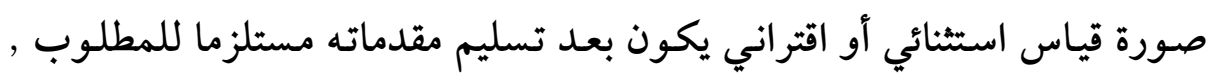

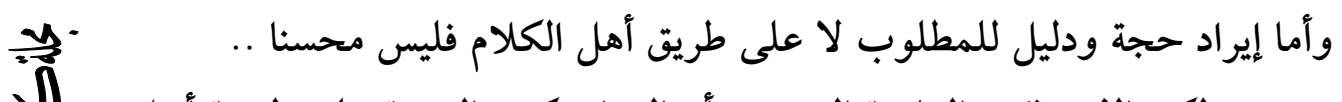

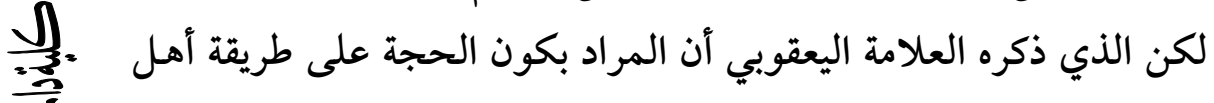

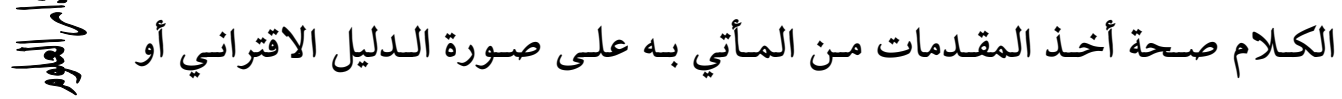

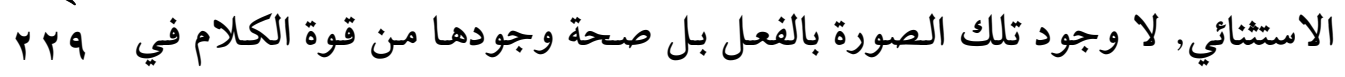

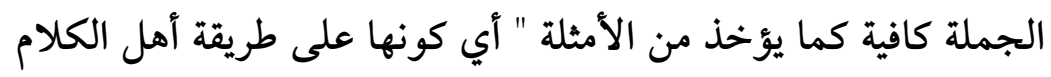

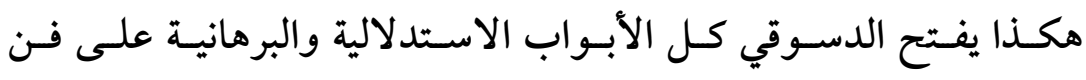

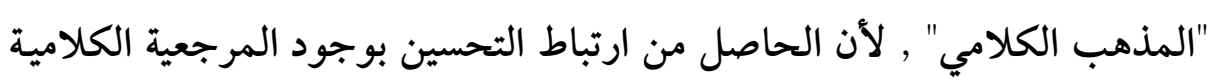
هو انفساح هذا الفن لاستيعاب مزيد من التأويلات البرهانية المؤسسة على مبلى مبدأ

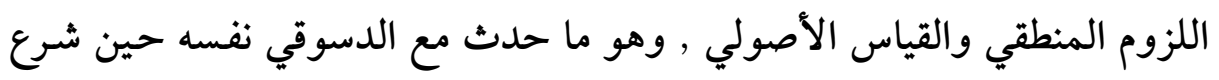

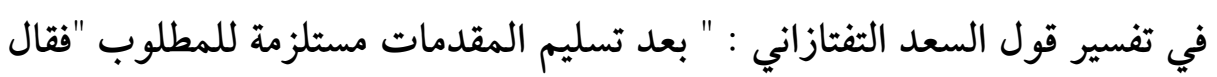

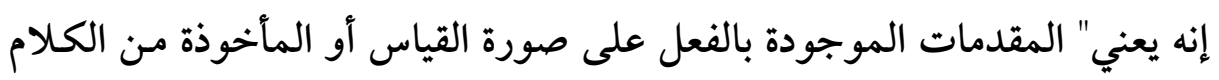
المأتي به , ومستلزمة للمطلوب : أي استلزاما عقليا أو ماديا" ....

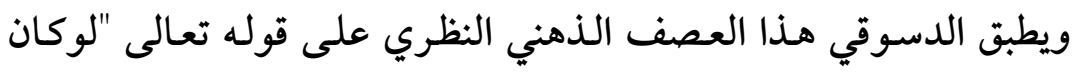

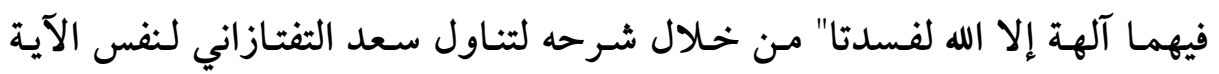

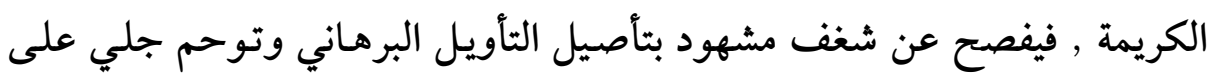




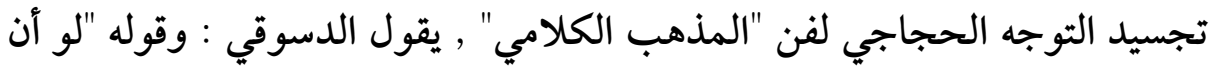

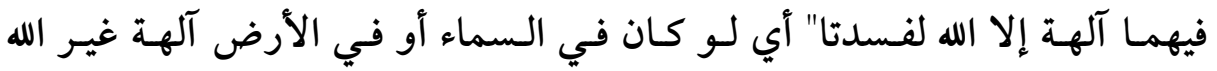

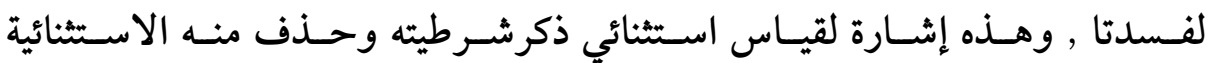
لكن وجود الفساد باطل بالمشاهدة , فبطل الملزوم وهو تعدد الآلهة,

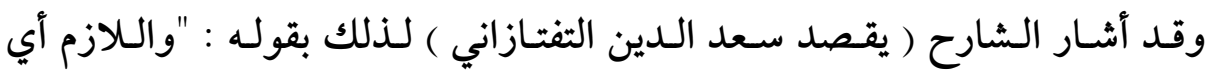

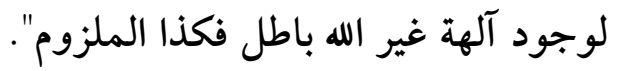

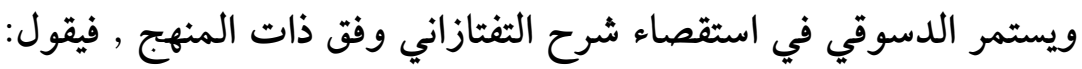

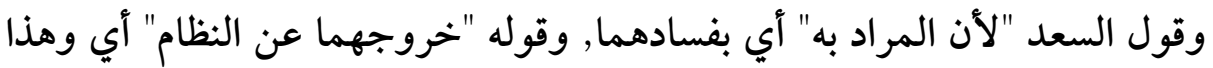

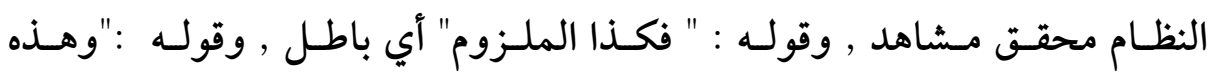

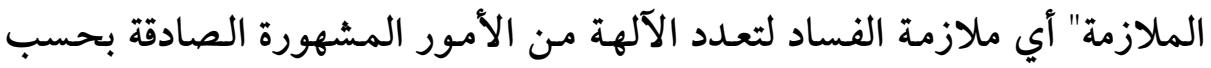

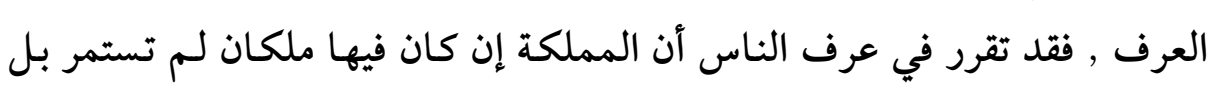

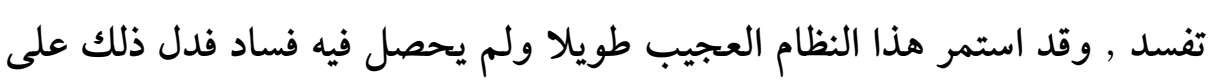

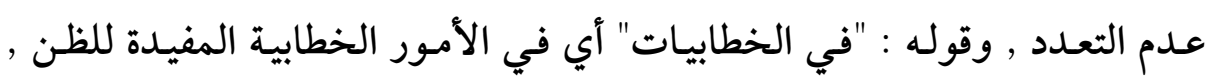

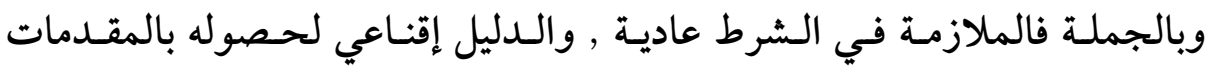

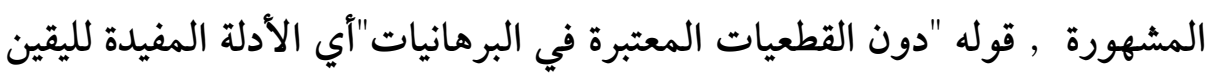

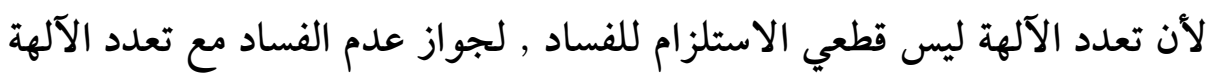

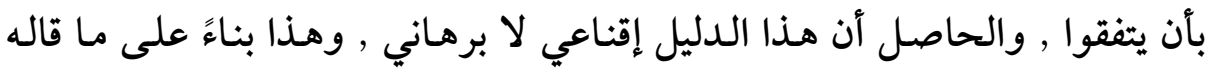

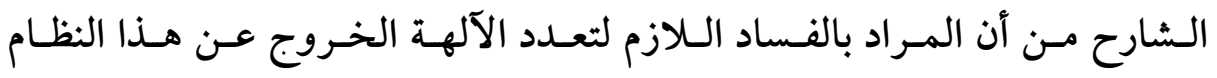

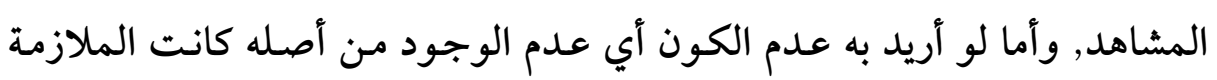

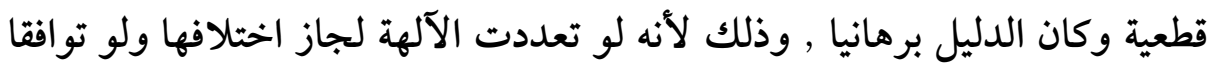

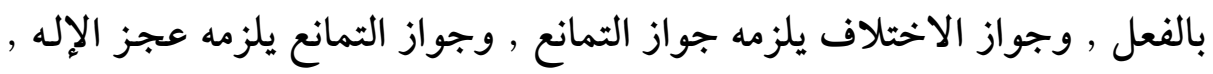

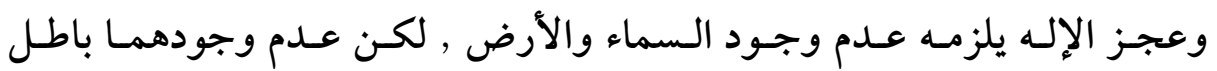

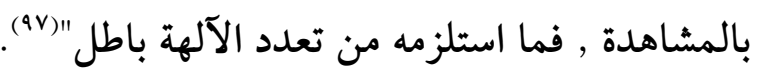


هكذا درج المتأخرون على أن كل بلاغي يضاعف من مساحة المحتوى البرهاني في نتاج سلفه تفصيلا وشرحا وتأويلا في المضامين النظرية دون التطبيق , فرغم تضخم هذا المحصول الوفير في الإطار النظري لفن المذهب الكلامي , ظلت شواهد هذا الفن محصورة في عدد محدود من العبارات القر آنية والأبيات الشعرية التي لاكتها مصنفات البلاغيين , دون أي إضافة أو تجديد..... ومن شأن هذا السلوك التصنيفي أن يبتعد بفن المذهب الكلامي خطوات أخرى عن ميدان الفن الأدبي ويقترب به خطوات مماثلة إلى حدود المنطق والجدل والحجاج , وهذا مـا حـدث في واقع الأمر , فبجانب الشواهد القر آنية المذكورة انحصرت شـواهد المـذهب الكلامي في عـد مماثل مـن الأبيات الشعرية هي على وجـه الحصر قول النابغة الذبياني يعتذر للنعمان :

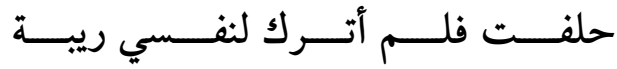

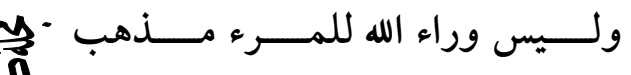
لــئن كنــت قــد بلغــت عنــي خيانسـة

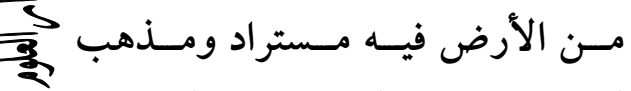

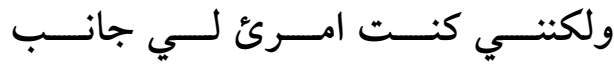

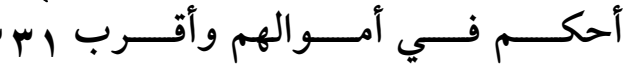

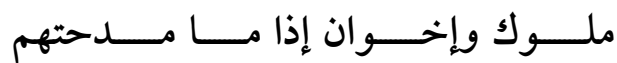
فلـم تـرهم في مسدحهم لـك أذنبـوا

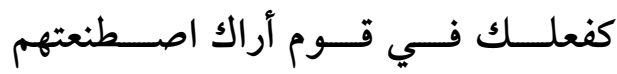

ونفــس يعاصــيها الفتـى ويطيعهــا

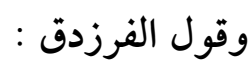

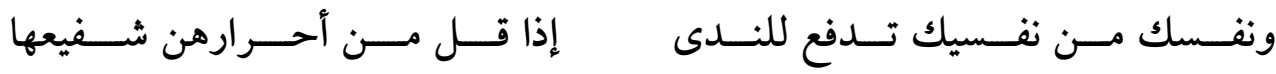

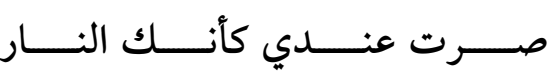
وقول أبي نواس :

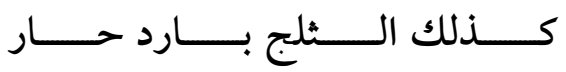

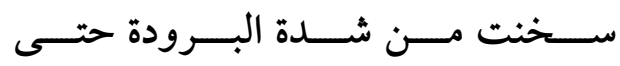
لا يعجـــب الــسامعون مـــن صــفني وقول إبراهيم بن المهدي : 
فيمـا فعلـت فلـم تعـذل ولــم تلــم

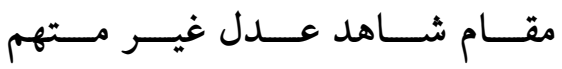

4

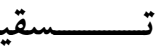

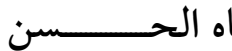

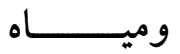

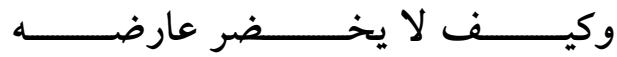

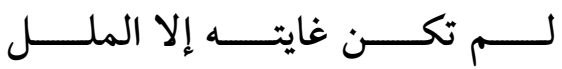

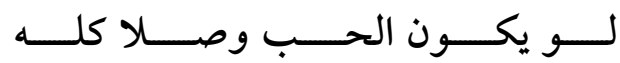

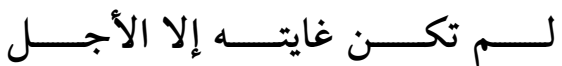

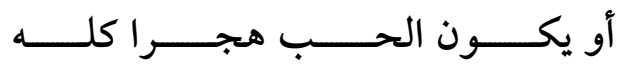

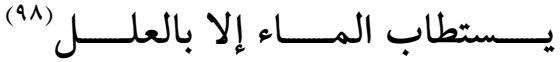

ولم يتجاوز البلاغيون هذه الشواهد المعدودة , وكأن ديوان الشعرالعربي

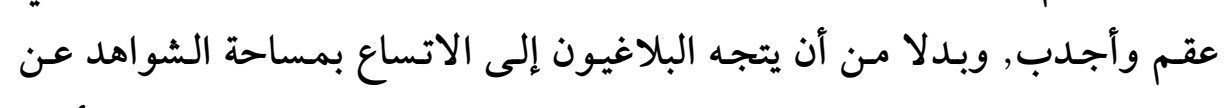

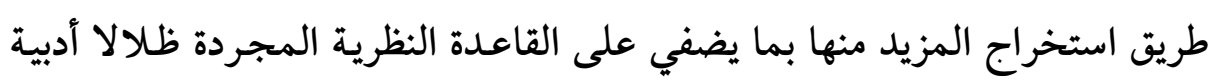

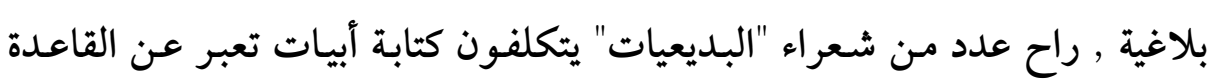

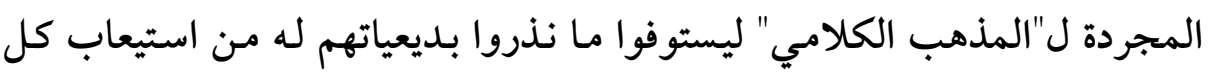

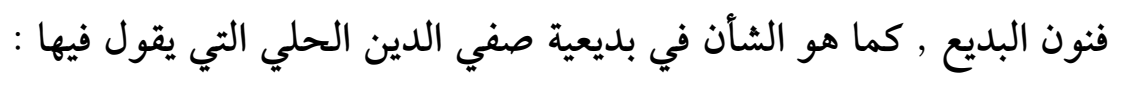

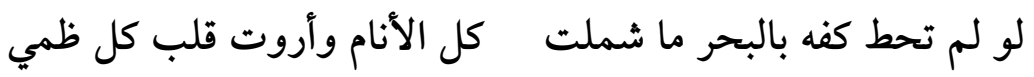
أو بديعية ابن حجة الحموي التي يقول فيها - متكلفا ذكر التسمية - :

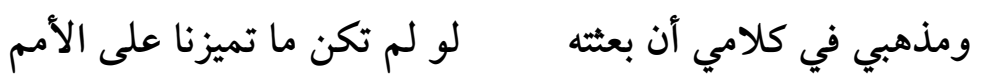

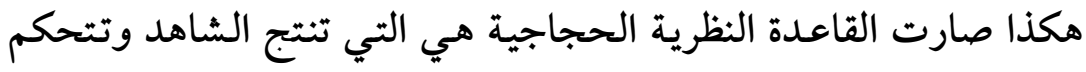

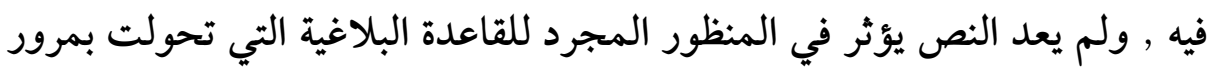

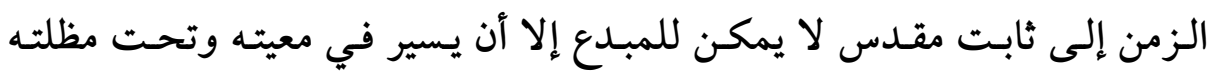

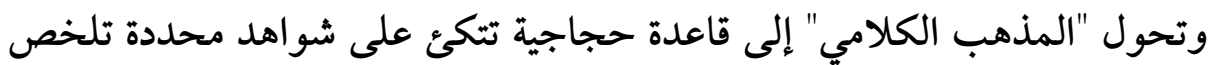

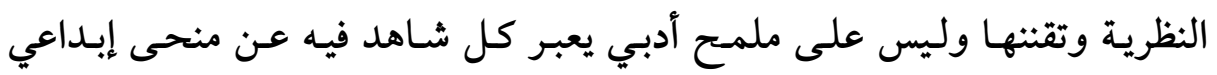

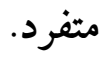


ويفصح تعامل البلاغيين مع الشواهد عن شغف مشهود بإثراء المضامين

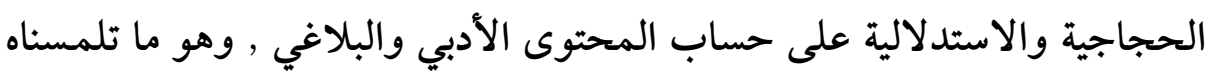

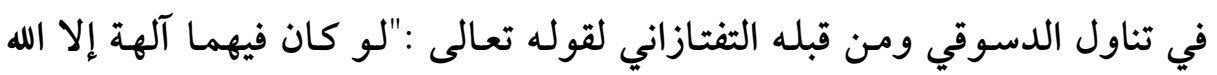

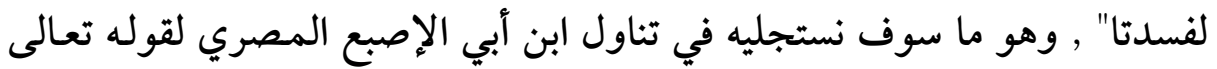

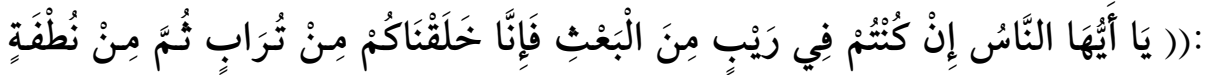

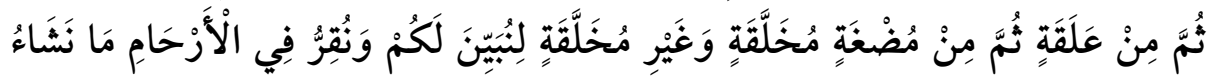

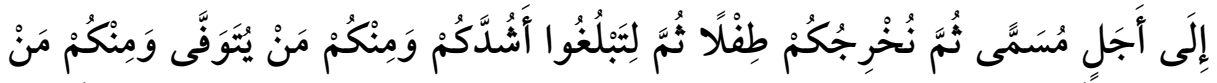

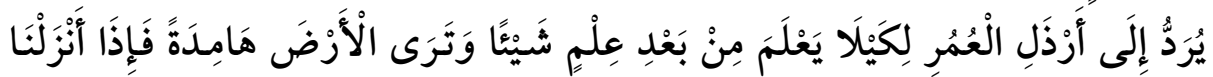

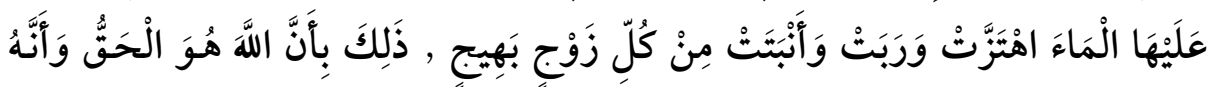

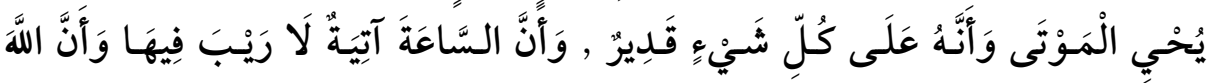

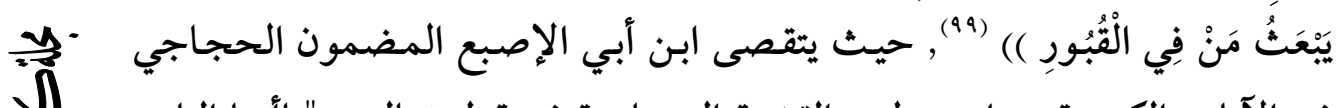

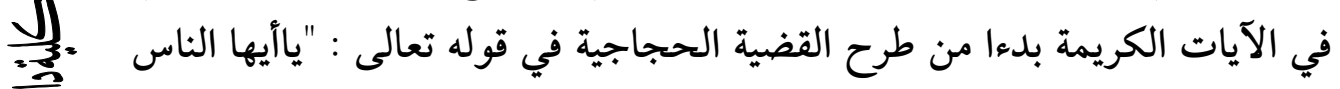

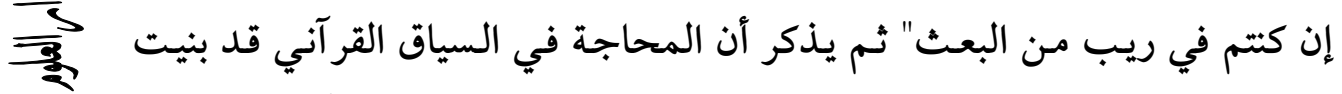

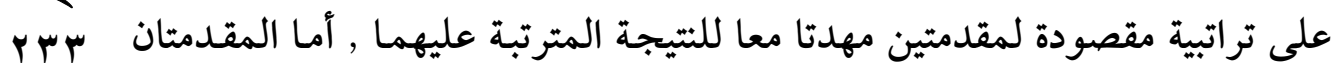

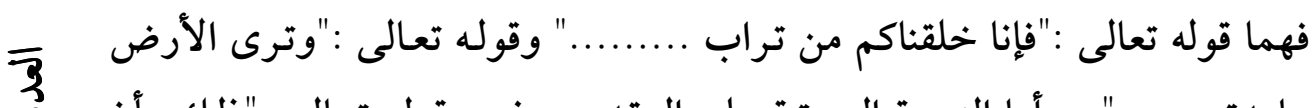

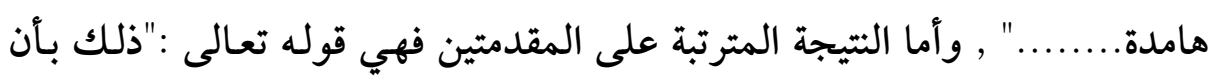

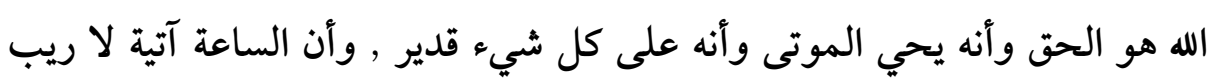

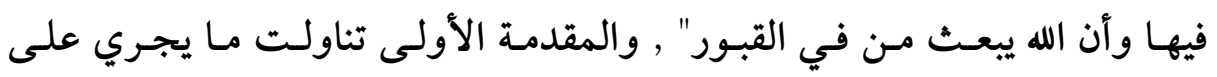

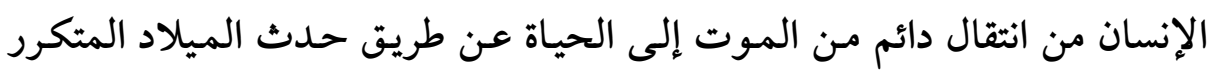

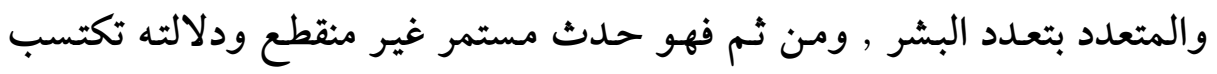

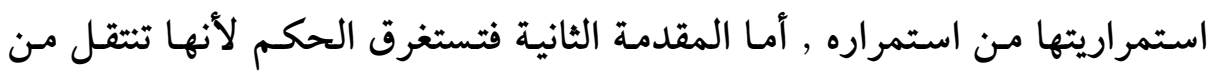

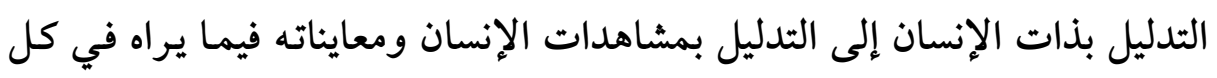

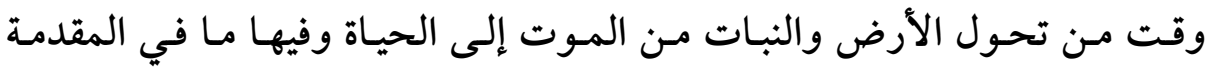

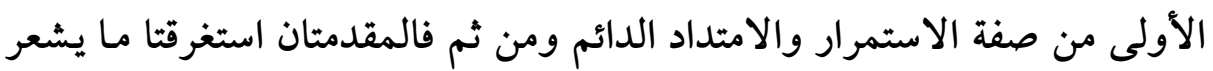
به الإنسان في نفسه وما يراه بعينيه مما يجعلهما يحتمان مصداقية النتيجة المترتبة ولانية 
عليهما والتي مؤداهـا مشمول بالآيتين الأخيرتين , وهـو أن الله حق وأن البعـث

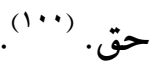

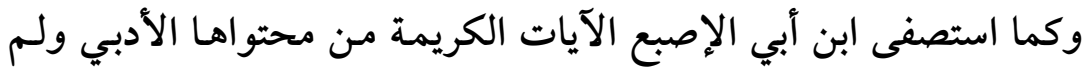

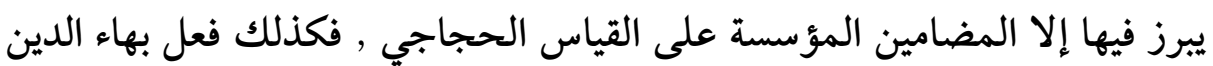
السبكي في الأبيات المذكورة للنابغة :

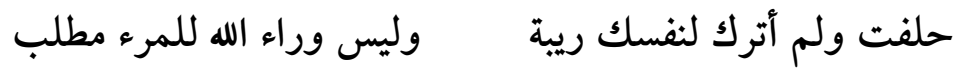
فلا يرى فيها إلا القياس الحجاجي المؤسس على مبدأ اللزوم المنطقي

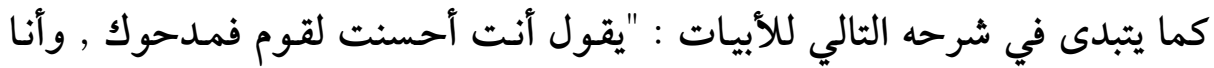

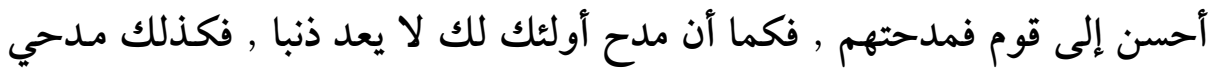

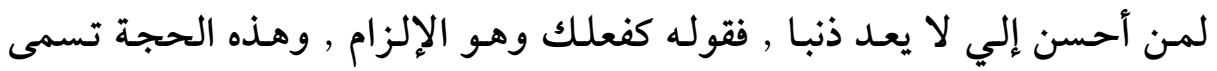

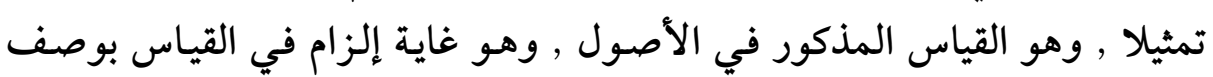

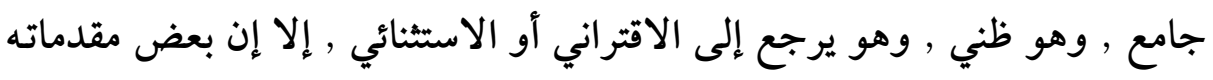

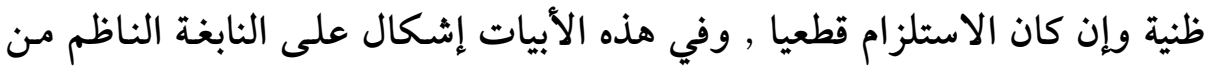

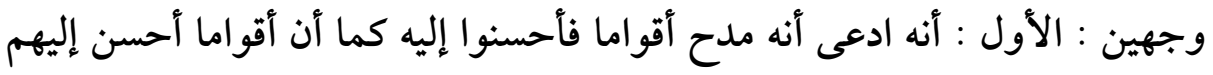

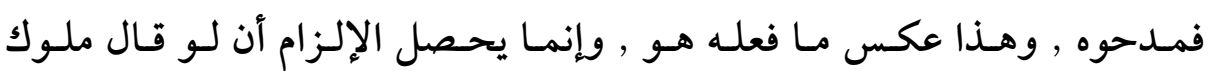

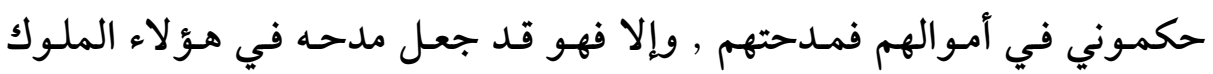

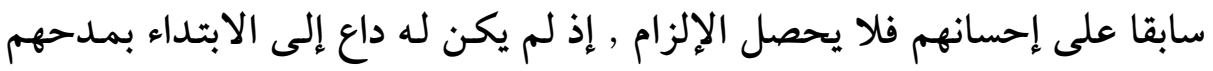

فلم ترهم في مدحهم لك أذنبوا

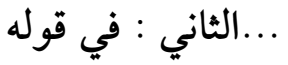

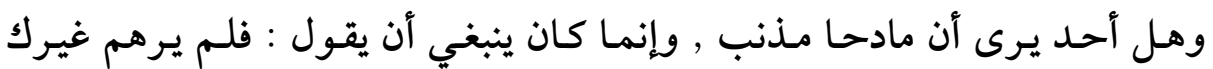

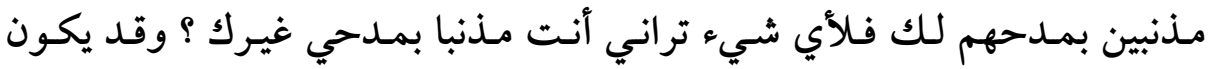

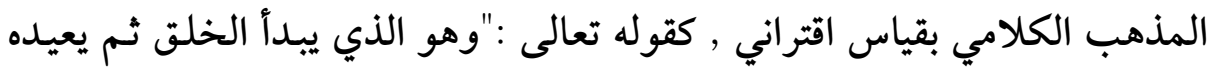

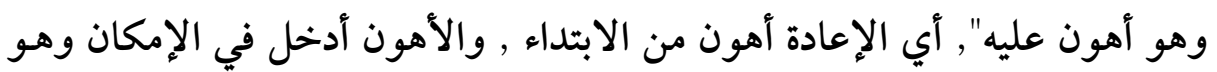
المطلوب ...." (1.1.) 
يـصطلح البلاغيـون على تسميته بالتعليل حينـا وحسن التعليل أحيانـا

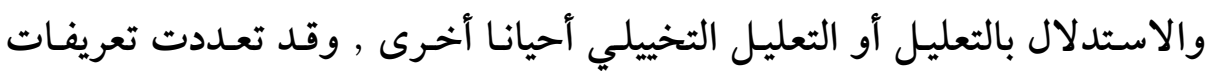

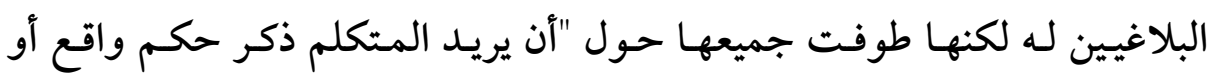

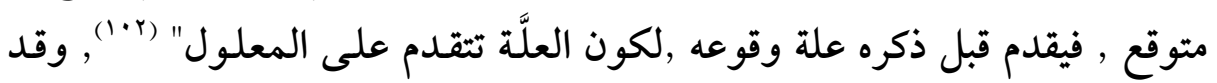

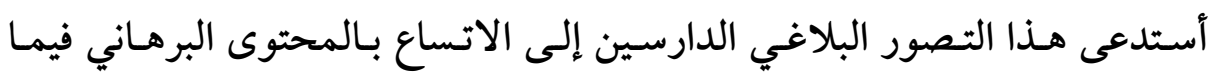

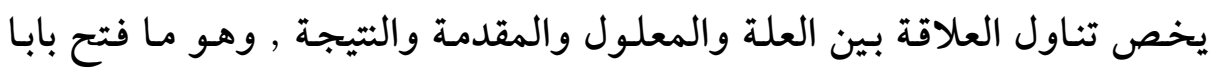

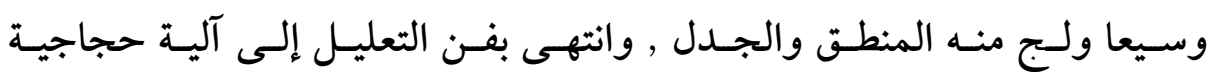
راسخة.... ويتبـدَّى ذلـك المنحسى الحجـاجي في اتجـاه البلاغيـين إلى الاهتمـام

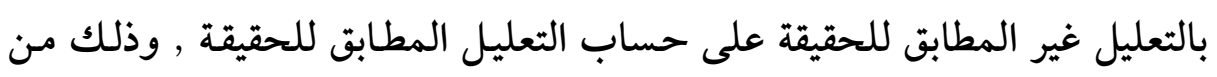

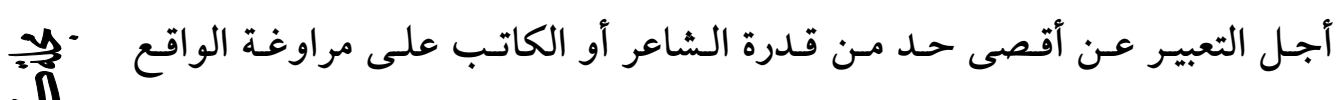
娄. وتشكيل واقع جديد في وعي المتلقي..

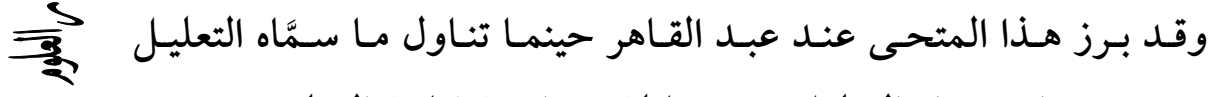

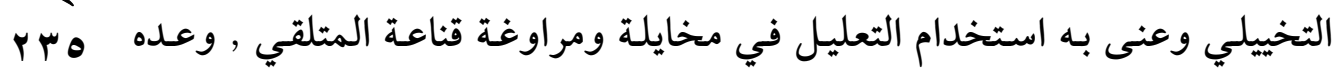
$\overline{3}$
2
2

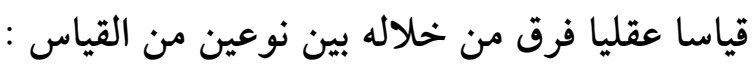
- قياس التخييل والإيهام.. - قياس التحصيل والإحكام. (r.r.).

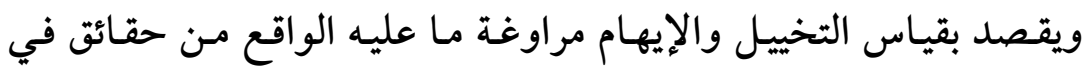

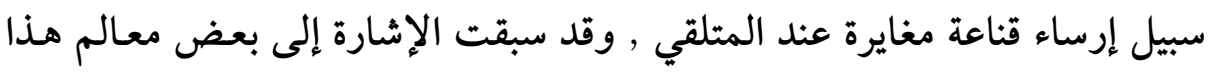

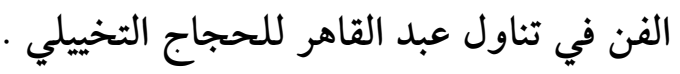

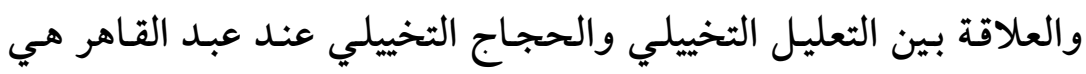

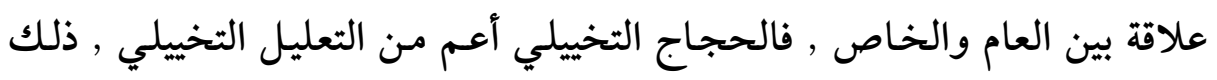

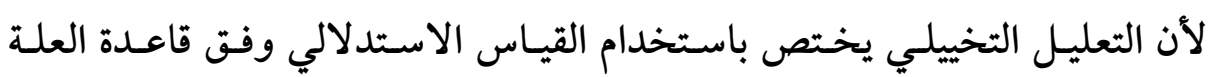

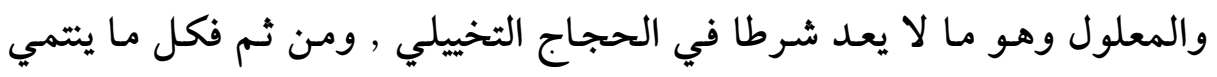




$$
\begin{aligned}
& \text { للتعليل التخيلي يدخل في باب الحجاج التخييلي وليس كل ما ينتمي للحجاج }
\end{aligned}
$$

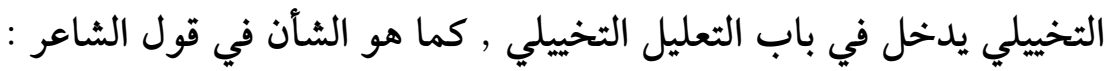

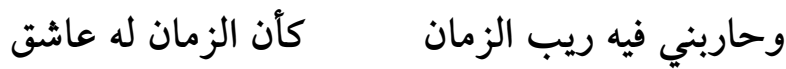

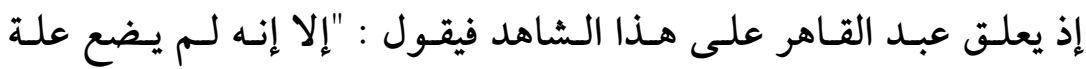

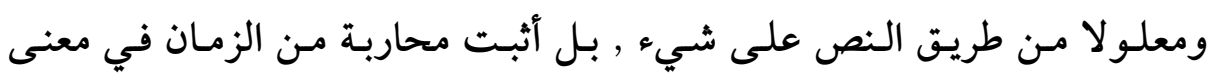

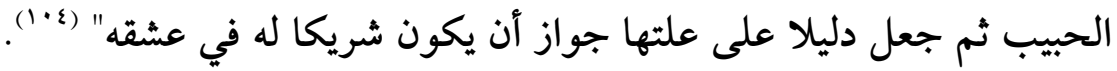

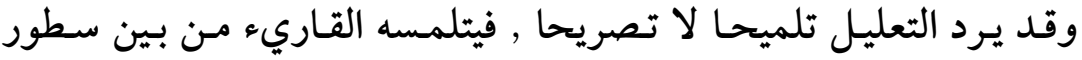

$$
\text { العبارة , كقول الشاعر : مقد يردات }
$$

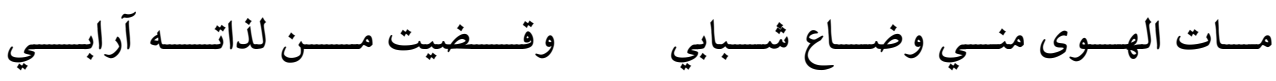

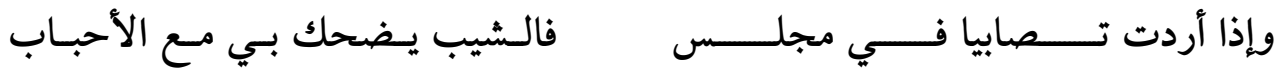

حيـث يتعلل الشاعر بالشيب على امتناعه عـن اقتراف مـا لا يليق بـهـ

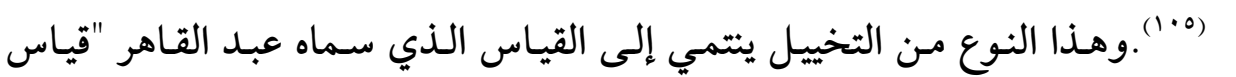

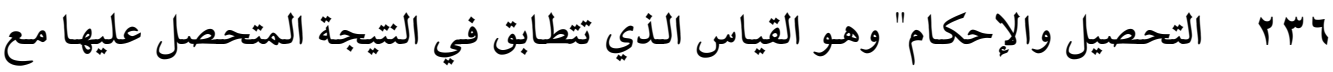

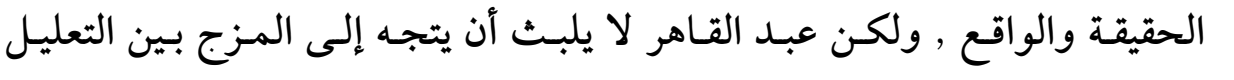

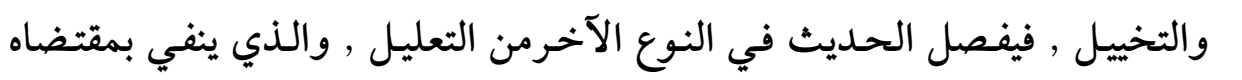

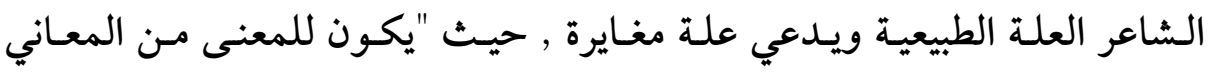

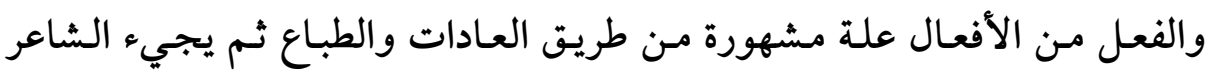
فيمنع أن يكون لتلك المعروفة ويضع له علة أخرى " (†.'), كقول المتنبي :

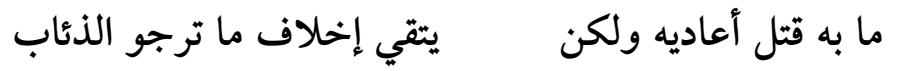

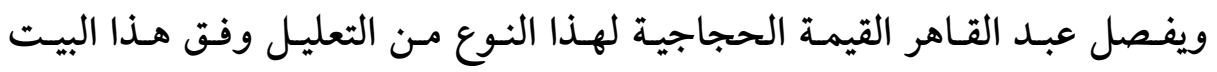

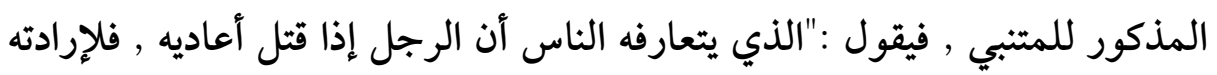

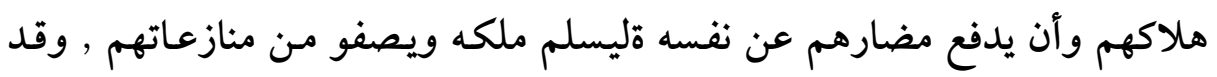

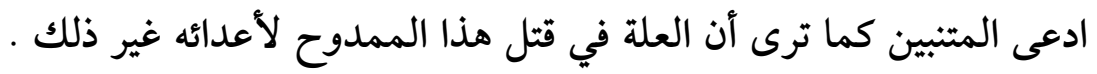


"واعلم أن هذا لا يكون حتى يكون في استئناف هذه العلة المدعاة فائدة شريفة فيما يتصل بالممدوح أو يكون لها تأثير في الذم , كقصد المتنبي ههنا في

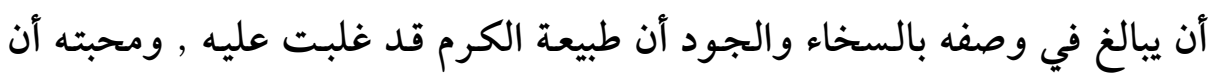
يصدق رجاء الراجين وأن يجنبهم الخيبة في آمالهم قد بلغت بـه هذا الحد , فلما علم أنه إذا غدا للحرب غدت الذئاب تتوقع أن يتسع عليها الرزق ويخصب لهب لهاء الوقت في قتلى عداه كره أن يخلفها وأن يخيب رجاءها ولا يسعفها , وفيه نوع

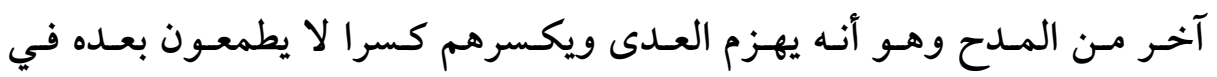
المعاودة فيستغني بذلك عن قتلهم وإراقة دمائهم , وأنه ليس ممـن يسرف في في لفي القتل طاعة للغيظ والحنق ولا يعفو إذا قدر" (v•l). هكذا انتهى عبـد القـاهر إلى تقـسيم التعليـل إلى تعلى إدليل مطابق لقيـاس

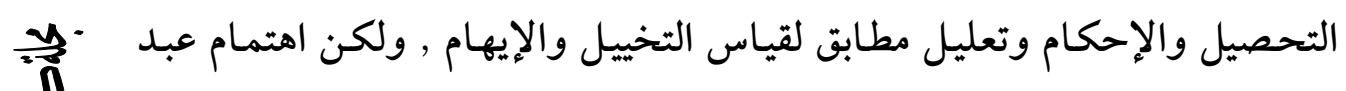

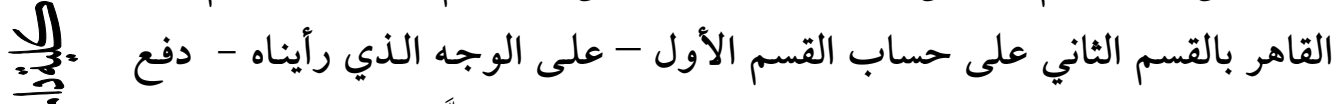

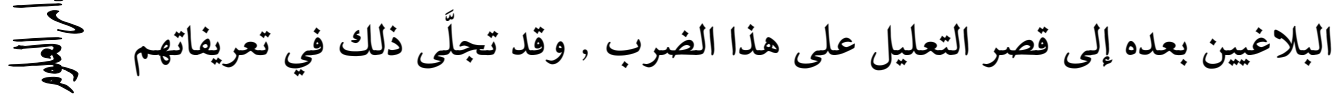

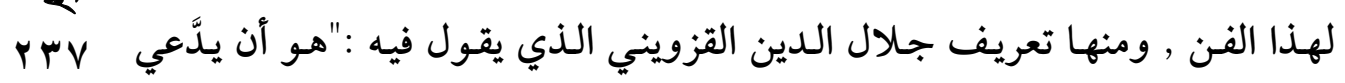
لوصف علة مناسبة له باعتبار لطيف غير حقيقي " (^+1), وقد قصد القزويني إلى اختيار كلمة "يدعي" للدلالة على أن القائل إنما يقدم على قول غير ثابت رئ , وأكد على هذا المنحى حين قال "اعتبار لطيف غير حقيقي" , وهو الوجه الذي فصله فيله الشراح في تفسيراتهم لاصطلاحات التعريف , كما هـ الشأن لدى عبد الفتاح

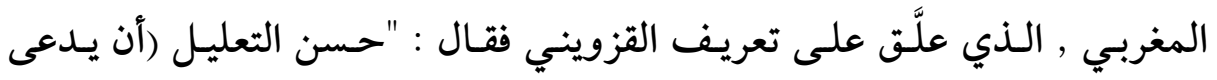
لوصف علة مناسبة له) أي أن يثبت لوصف علة علة مناسبة , ويكون ذلك الإثبات بالدعوى , ولتضمُنْ (يدعي) معنى الإثبات عُدِّى إلى الوصف باللام , وقد تقدم

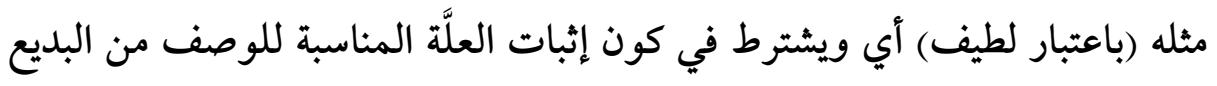
أن يكون إثبات تلك العلة المناسبة مصاحبا للاعتبار , أي لنظر من العقل لطيف ,

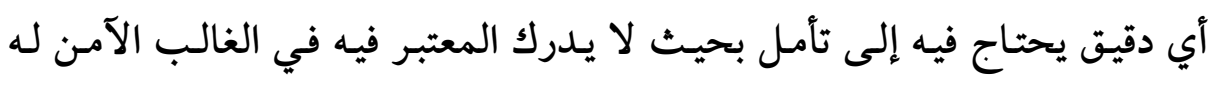
تصرف في دقائق المعاني وفي الاعتبارات اللطيفة (غير حقيقي)نـت للاعتبار 
بمعنى المعتبر , أي يكون غير حقيقي , أي غير مطابق للواقع , بمعنى أنه ليس

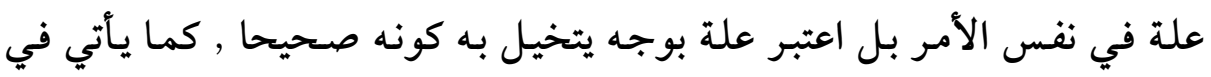

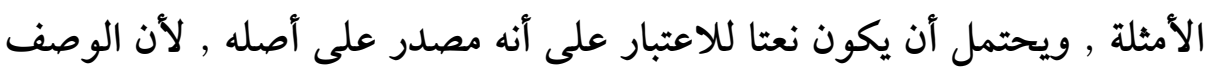

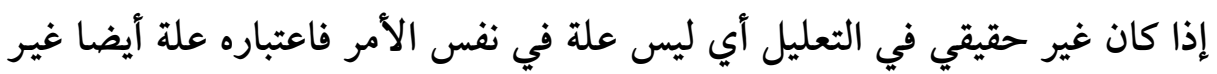

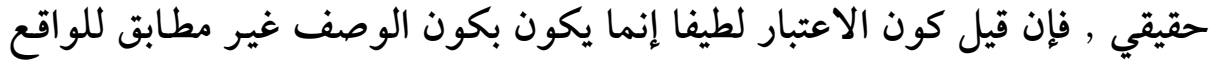

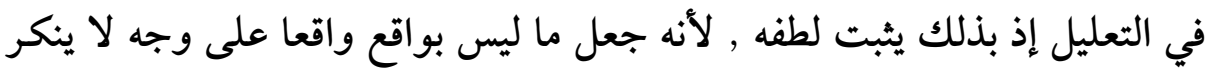

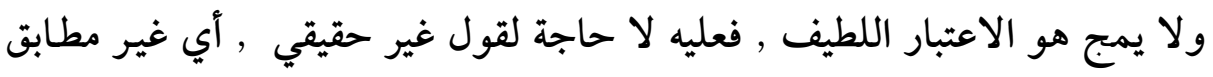

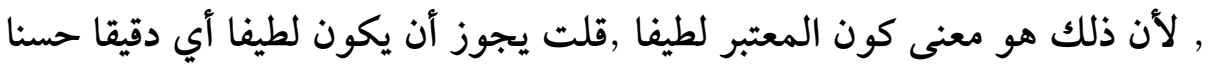

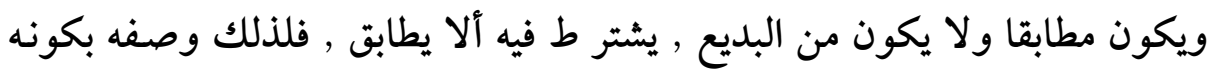

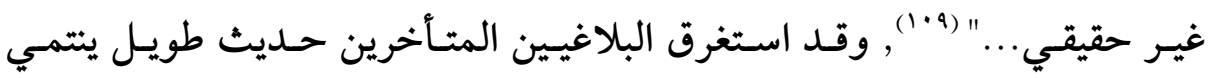

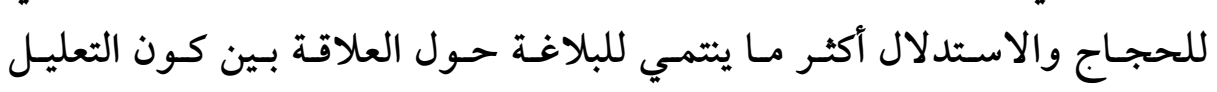

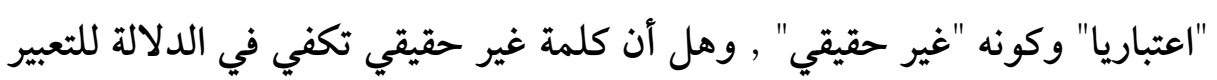

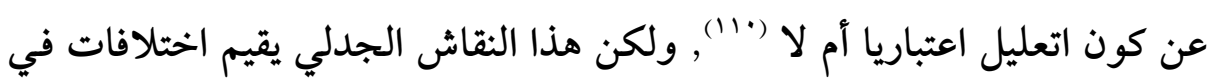

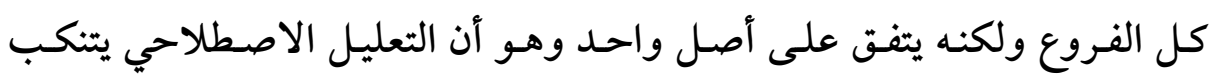
الحقيقة الواقعية المحكمة , ليرسي دعائم الرؤية التخييلية المتوهمة...

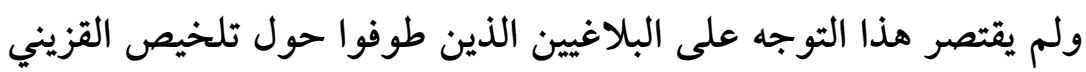

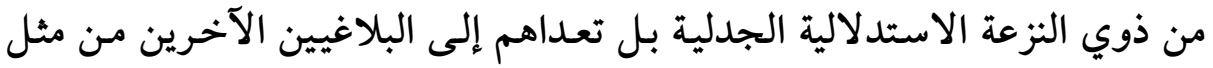

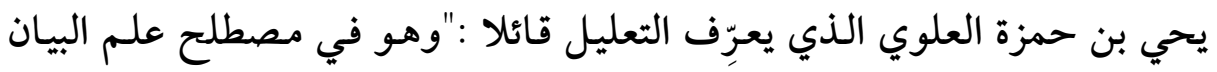

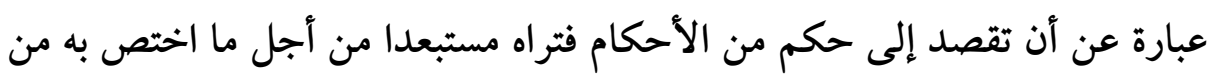

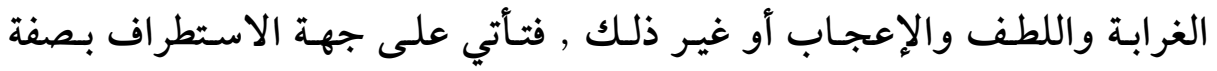

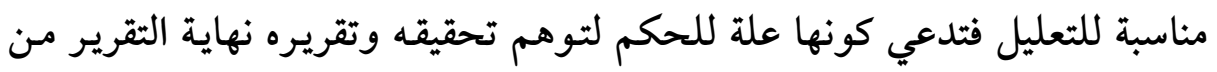

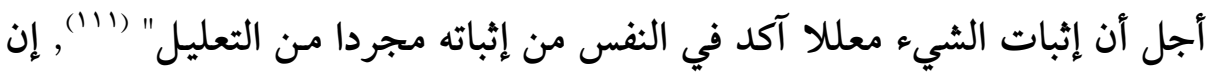

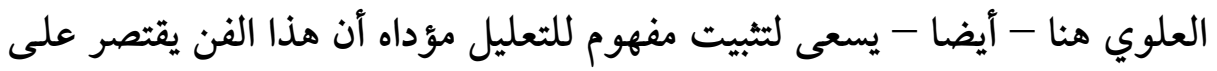

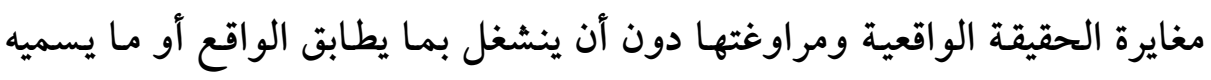


عبد القاهر الجرجاني :"قياس التحصيل والإحكام" , وهو - أي العلوي - يفصح

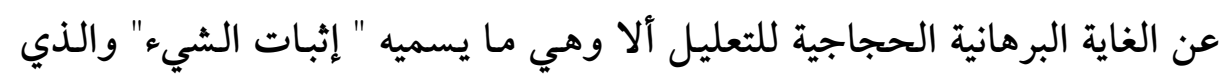

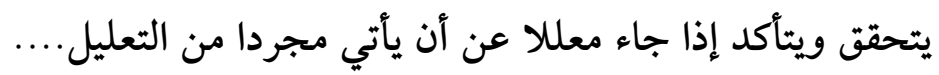

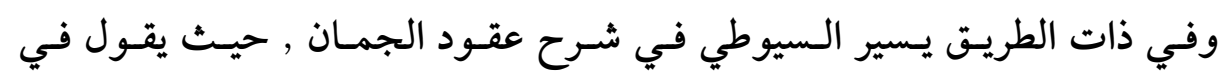

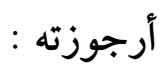

والحسـسن فــي التعليـل أن يرعيــا

بلطف معنى لا حقيقي يصحب (iir).

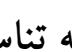

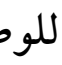

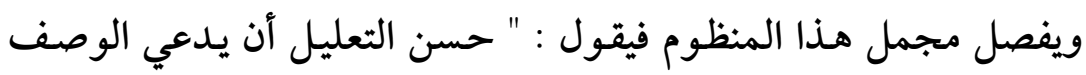

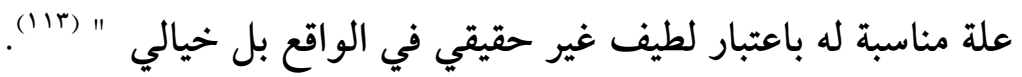

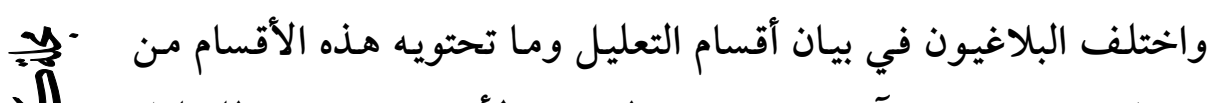

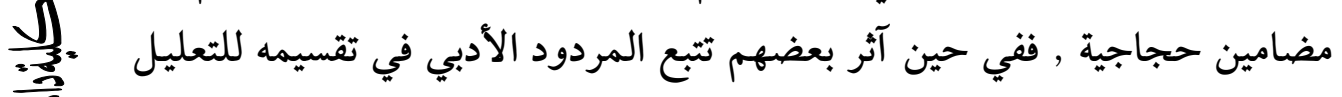

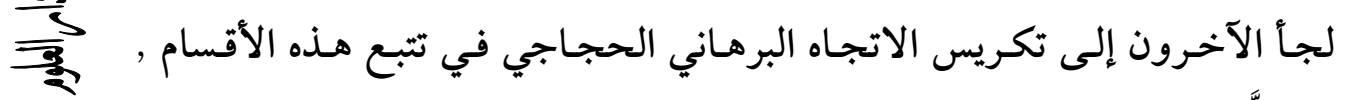

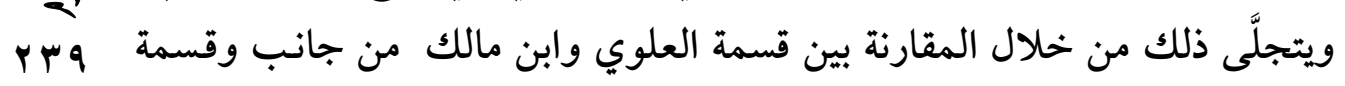

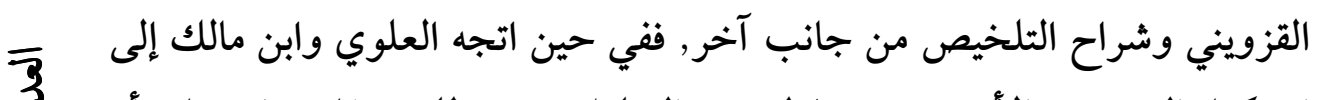

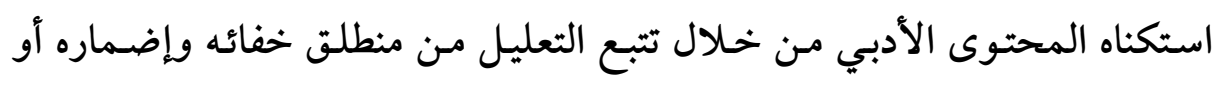

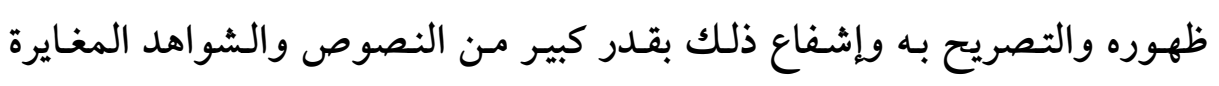

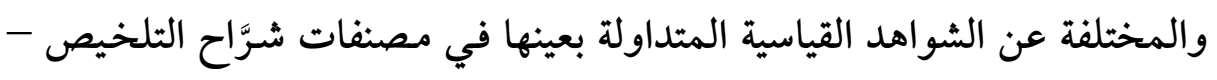

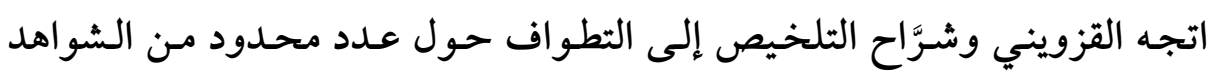

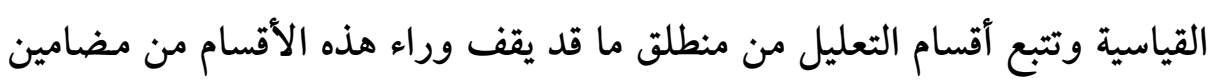

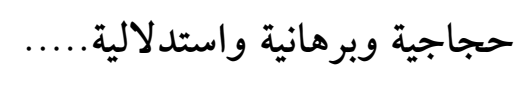
أولا : قسمة العلوي وابن مالك للتعليل :

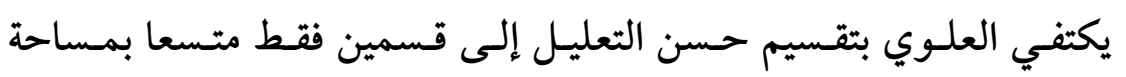

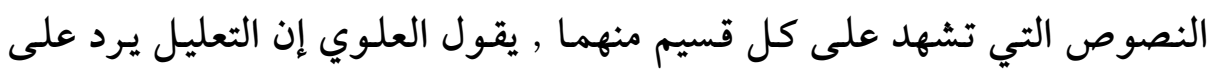




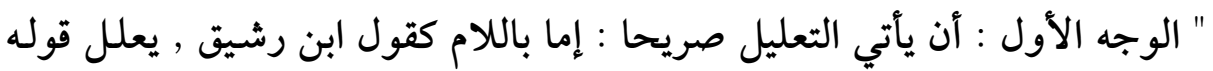

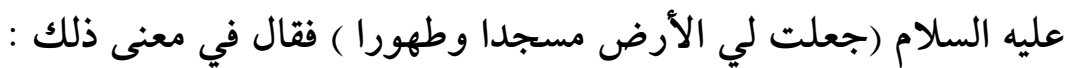

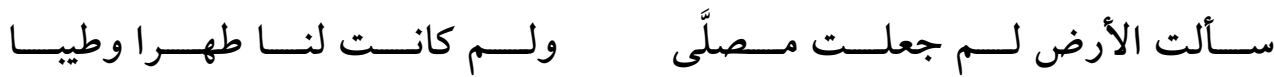

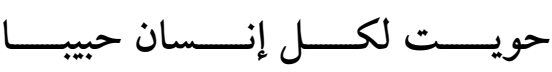

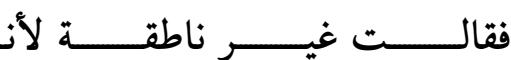

ولقد أحسن في الاستخراج وألطف في التعليل , فلأجل ما قاله كان ذلك

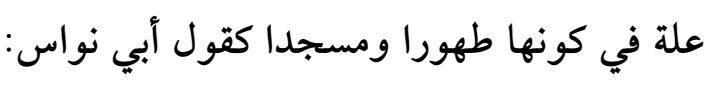

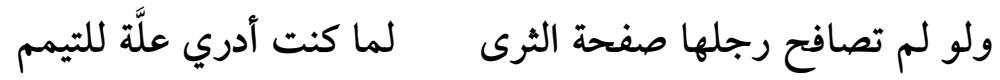

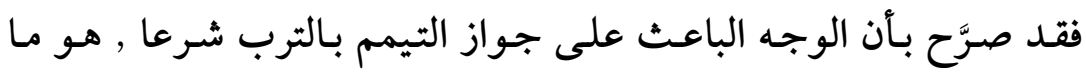
ذكره من وطئها له بأخمص قدميها فلأجل ذلك كان جائزا....

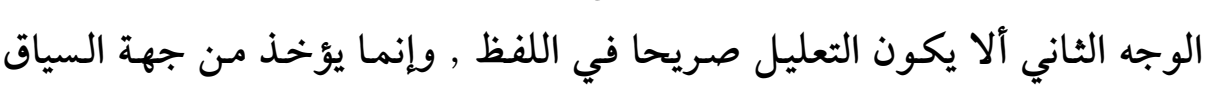
والنظم والمعنى , وهذا كقول بعض الشعراء :

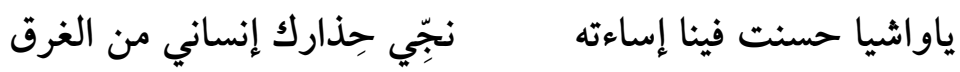

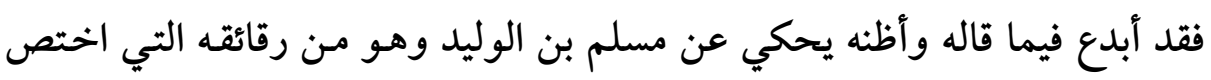
Y $\leq$.

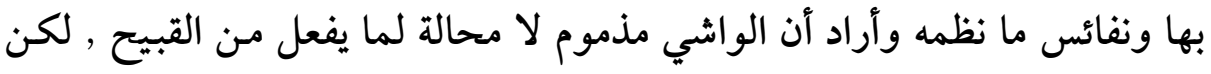

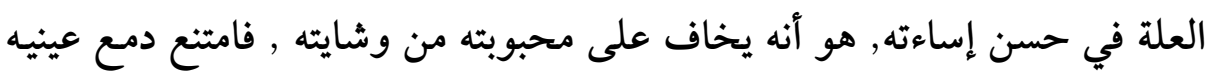

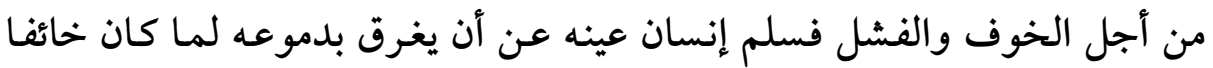

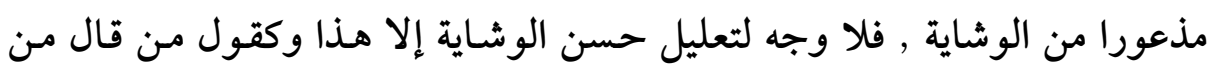
الشعراء : المغران فإن غارت الغدران من صحن وجنتي فلا غرو منه لم يزل وابل يهمي" (1'أ.

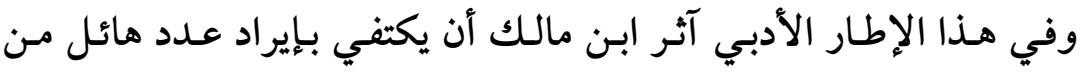

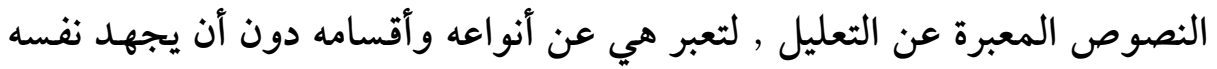

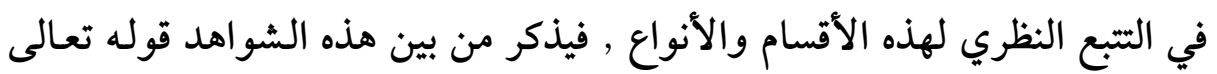

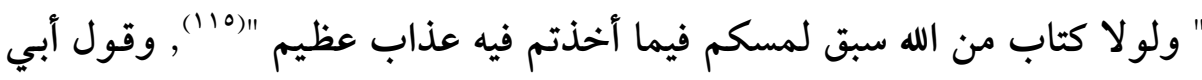


إلى الغيـث حتى جادهـا وهـو هـانع ربــا شــفعت ريــــ الــصبا بنـسيمها

حبيبا فمـا ترقى لهـن مــامع (11')

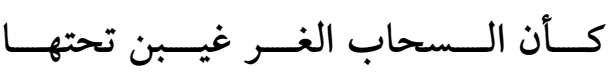

\section{ثانيا : قسمة القزويني وشرًَ التلغيص للتعليل :}

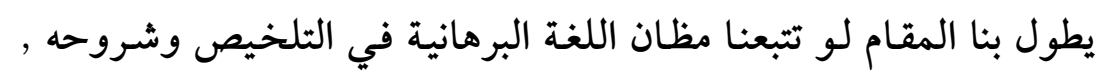

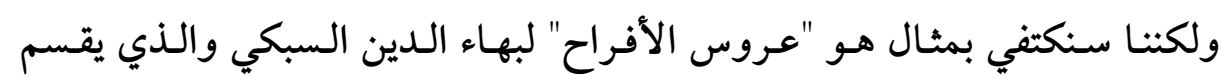

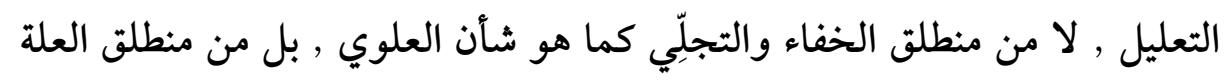

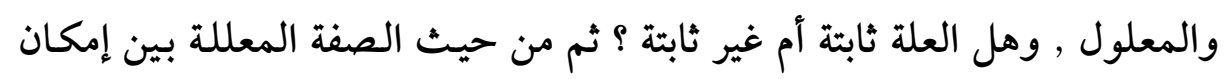

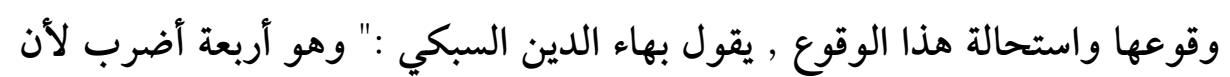

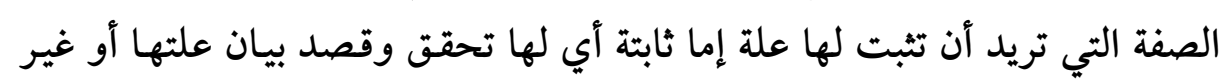

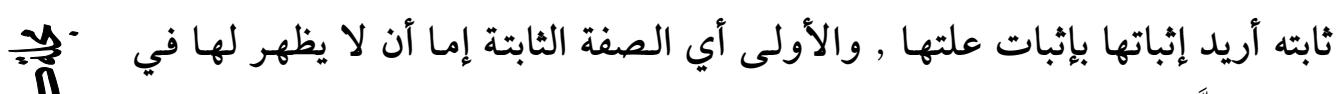
㗼

$r \leqslant 1$

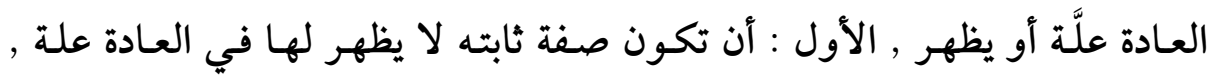

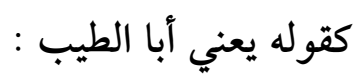

لم يحك نائلك السحاب وإنما حمت به فصبيبها الرحضاء

فالوصف الثابت المعلل هو نزول المطر , ولا يظهر له في العادة علة ,

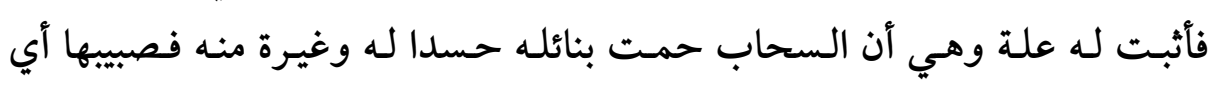

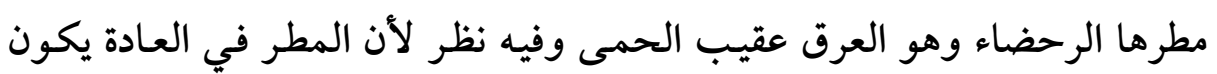

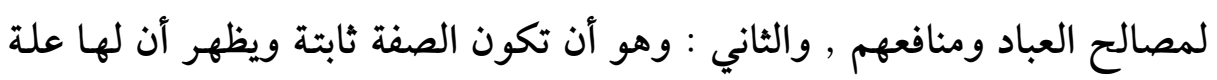

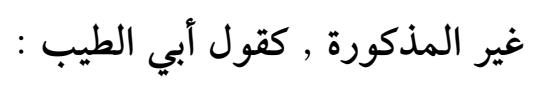

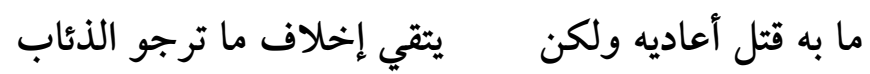

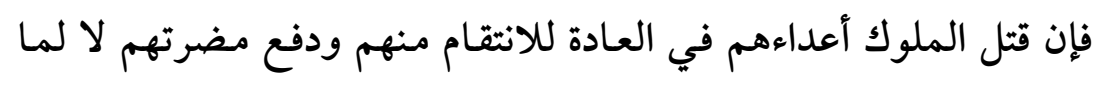

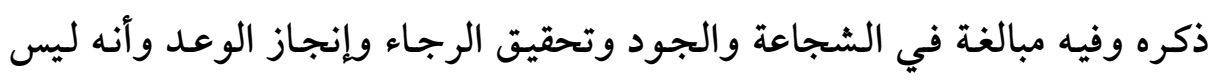

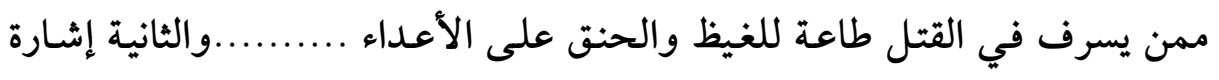
للصفة المعللة غير الثابتة إما ممكنة وهي الضرب الثالث كقئ والثن على الاعله أي قول مسلم بن 


$$
\text { ياواشيا حسنت فينا إساءته نجي حذارك إنساني من الغرق }
$$

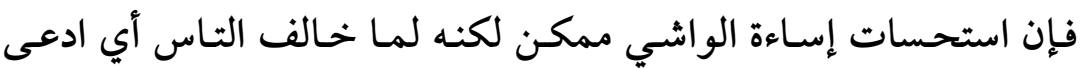

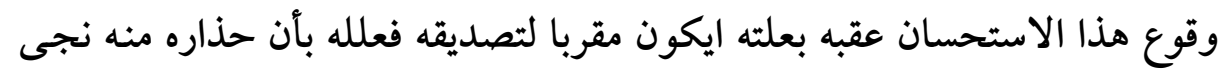

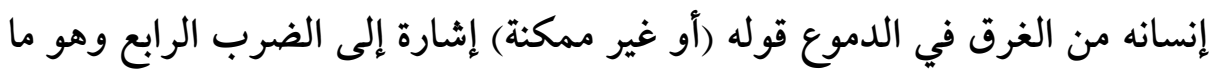

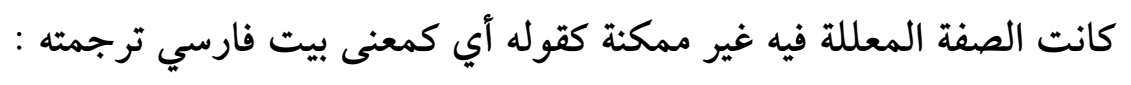

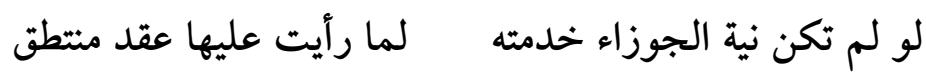

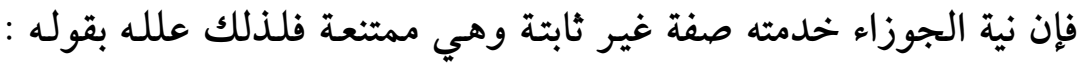

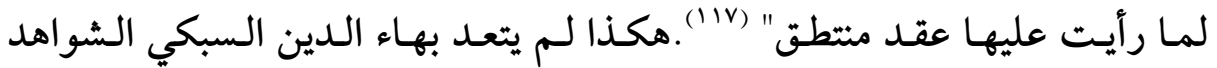

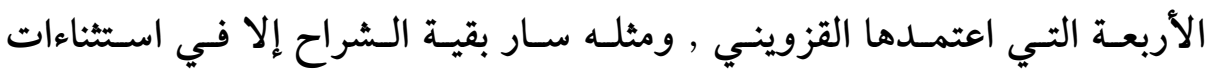

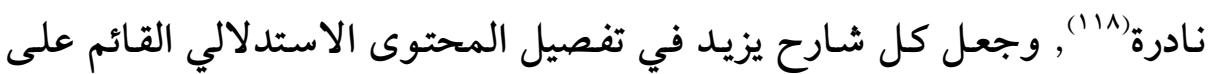

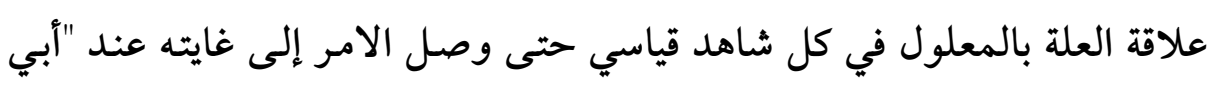

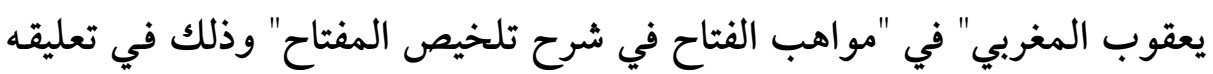

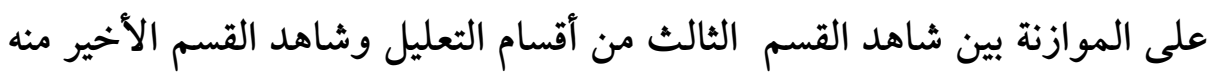

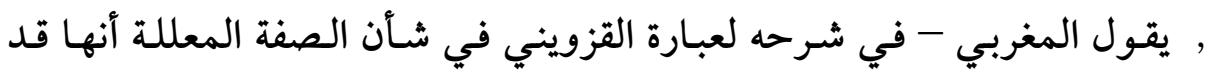

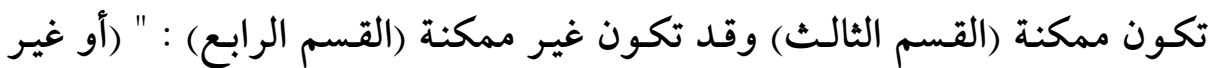

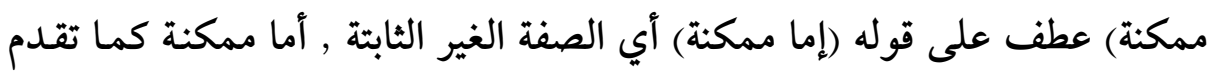
وإما غير مناسبة ادعى وقوعها وعللت بعلة تناسبها , كقوله :

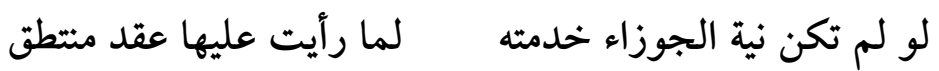

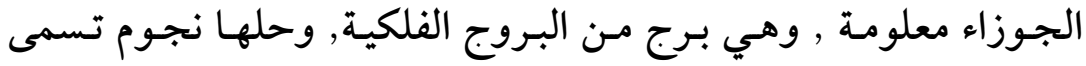

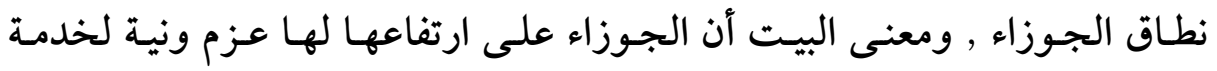

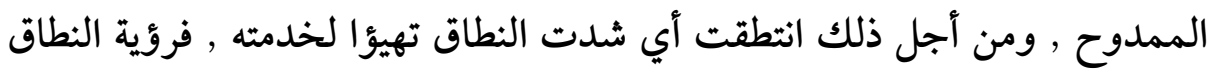

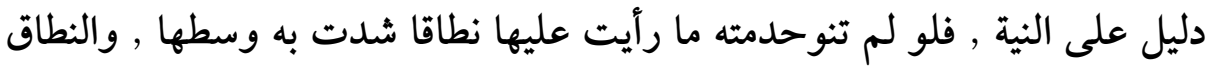

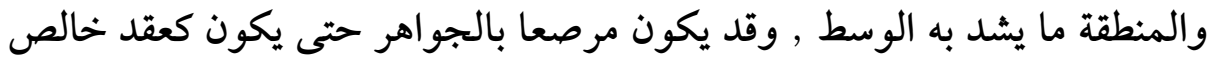

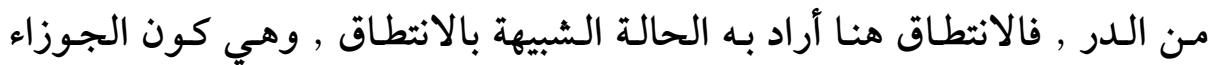


أحاطت بها تلك النجوم كإحاطة النطاق الذي فيه جوهر , فصار كعقد من الدر

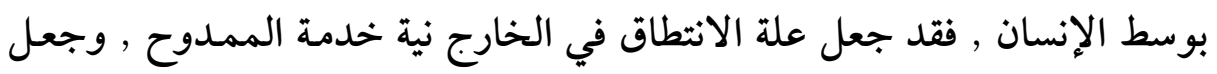

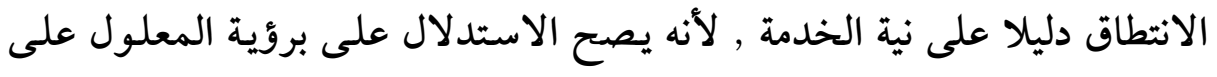

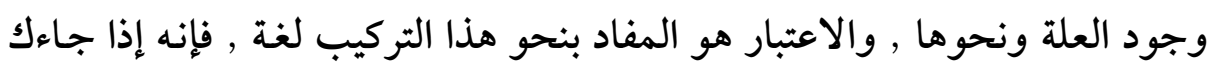

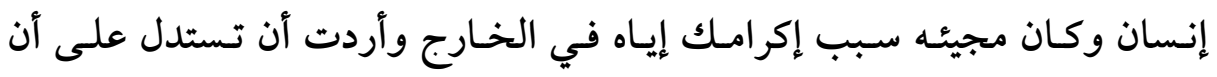

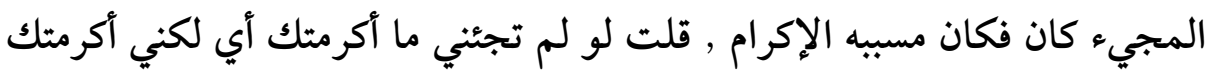

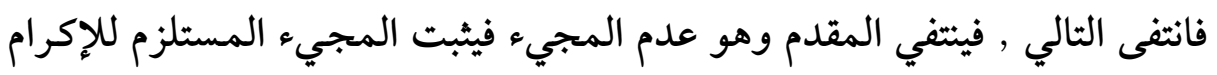

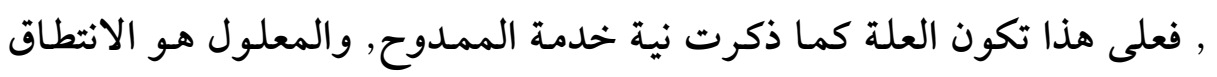

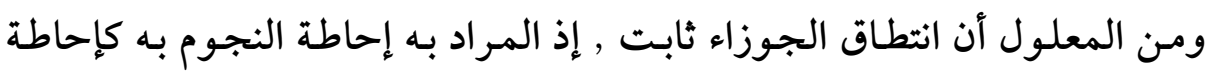

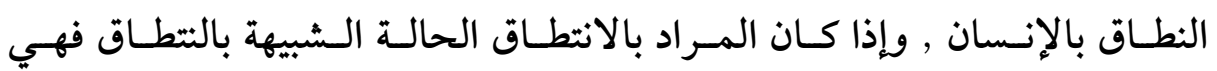

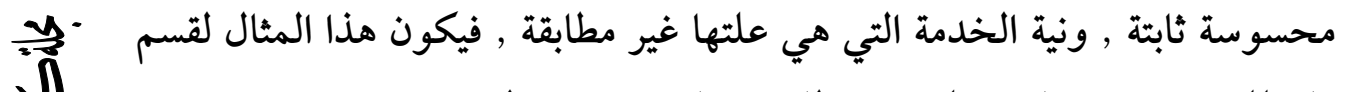
ما عللت فيه صفة ثابتة بعلة غير مطابقة كما تقدم في قوله :

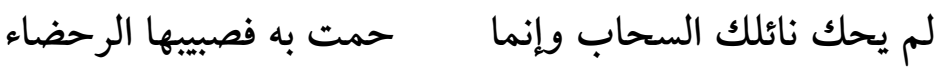

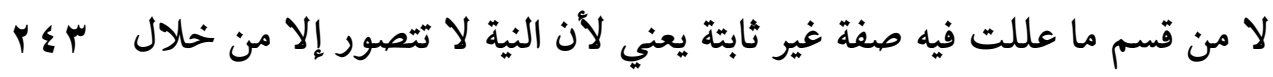

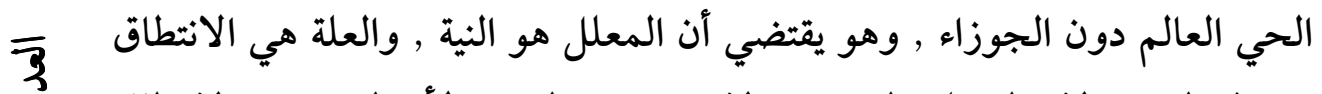

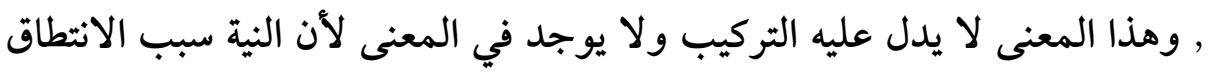

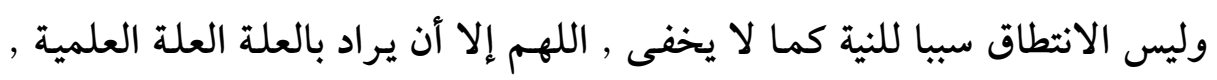

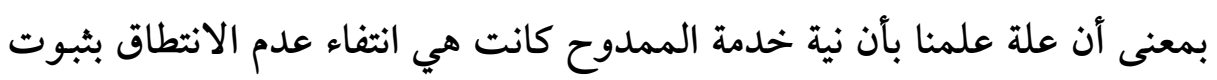

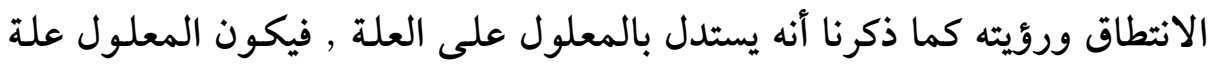

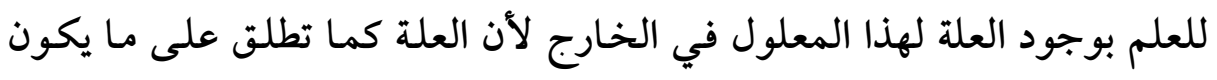

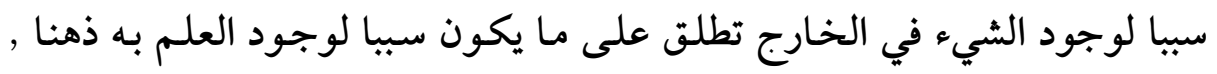

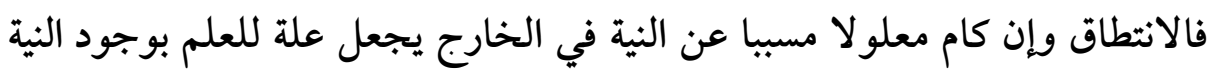

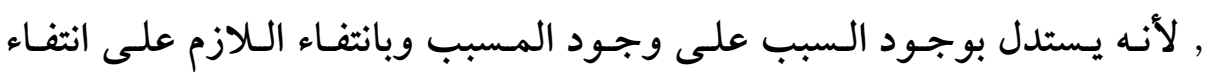

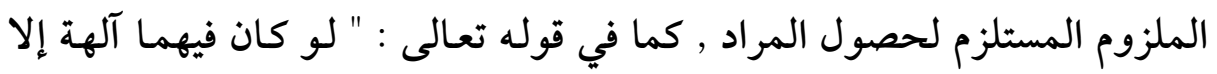
الله لفسدتا " , فإن انتفاء الفاسد انتفاء اللازم , ويكون علة لمعرد للعلم بانتفاء الملزوم 
الذي هو التعدد , فيثبت المراد الذي هو الوحدة وهذا ولو كان هو الأقرب لأن

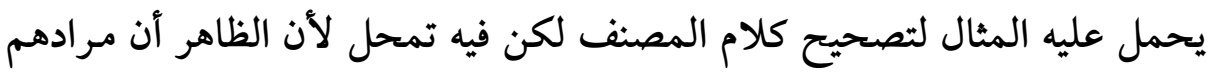

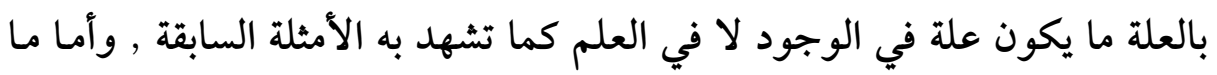

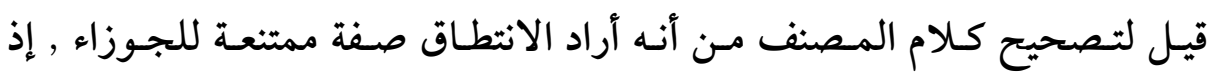

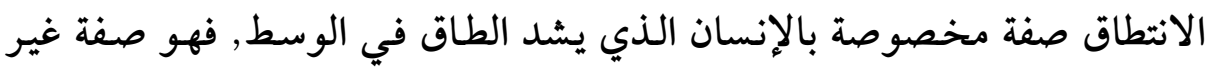

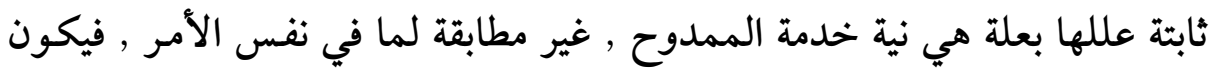

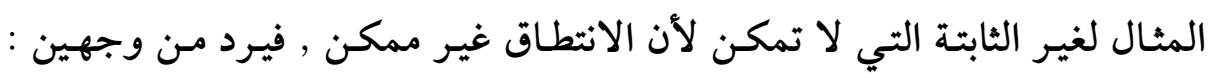

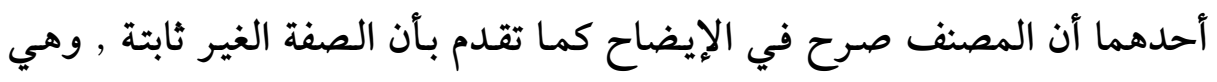

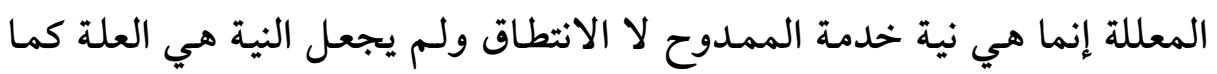

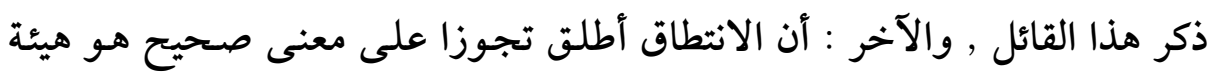

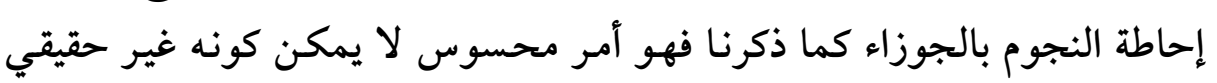

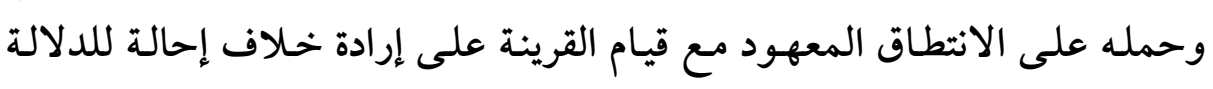

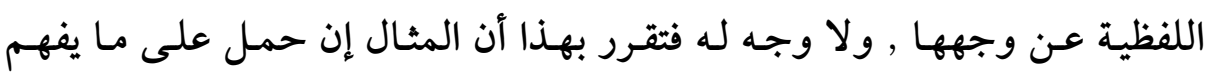

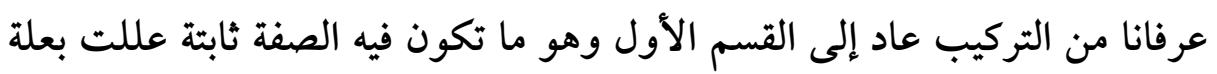

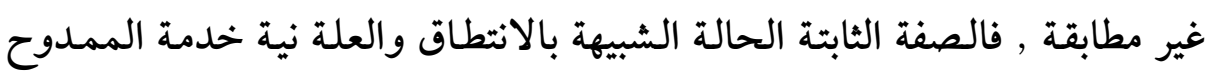

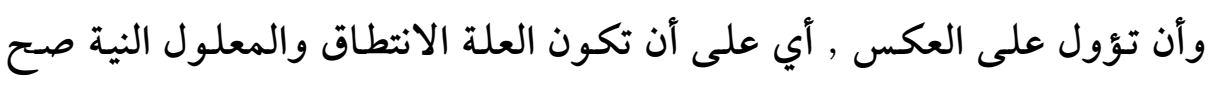

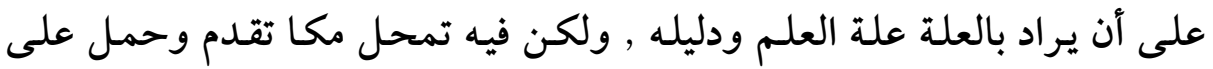
势

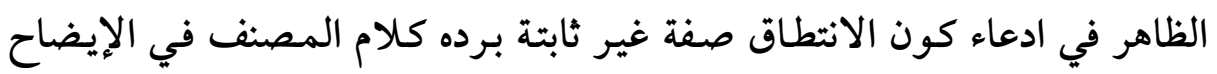

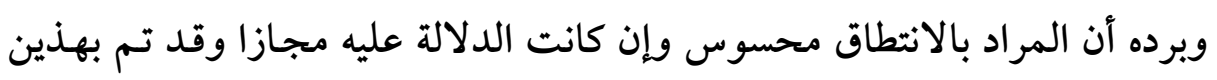

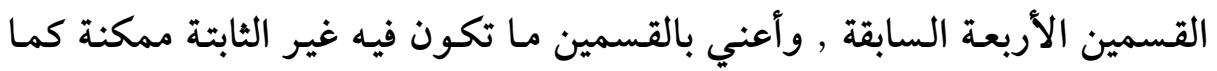

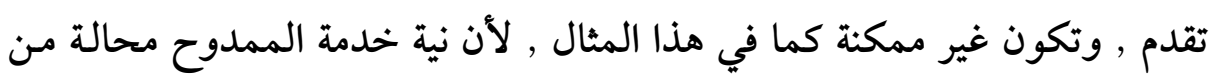
الجوزاء " (119)

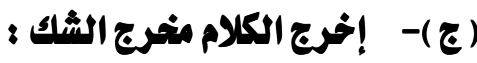

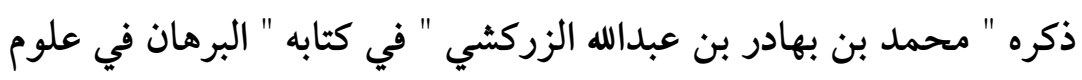

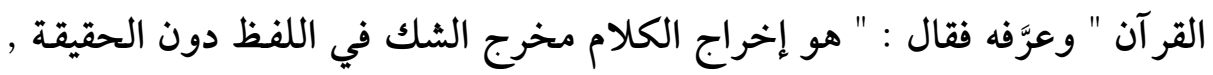


لضرب من المسامحة وحسم العناد " (•r), وجاء عليه بأمثلة منها قوله تعالى : "

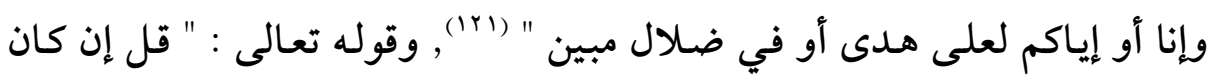

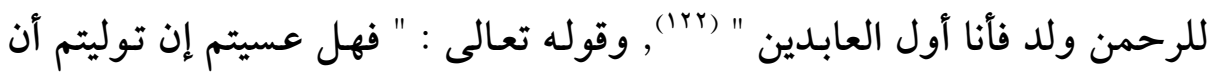
تفسدوا في الأرض وتقطعوا أرحامكم " (1rr).

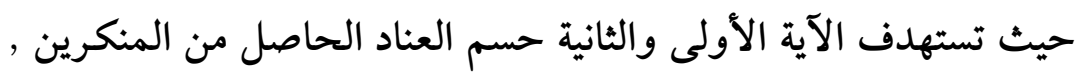

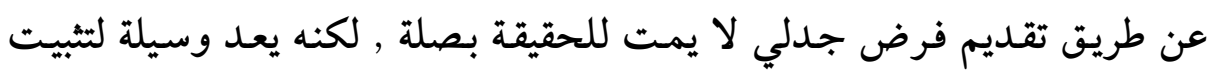

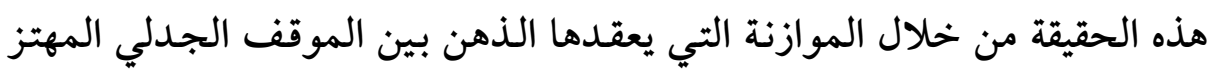

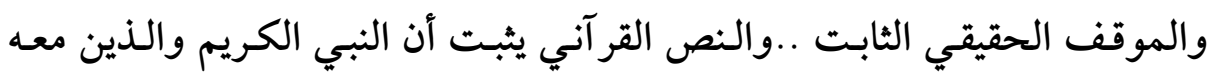

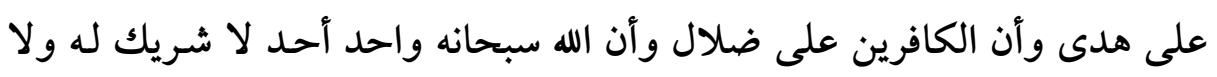

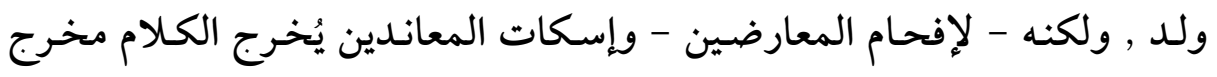
الشك في اللفظ دون الحقيقة لإثبات اليقين في الحقيقة دون اللفظ ل....

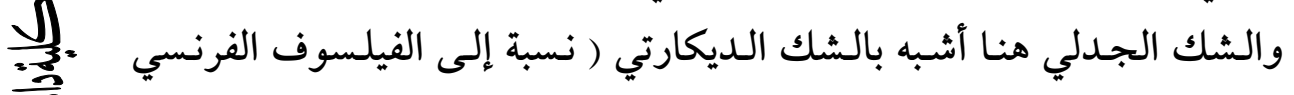

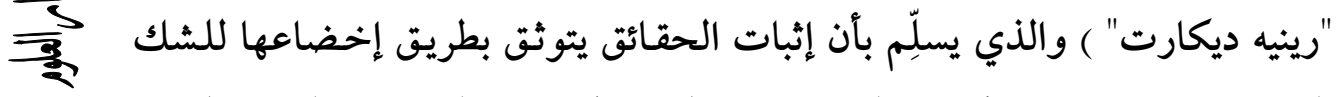

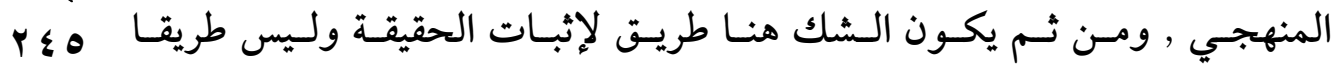

وفي الآية الثالثة خطاب للموحدين "أورده على طريق الاستفهام , والمعنى :

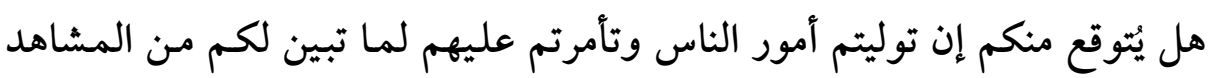

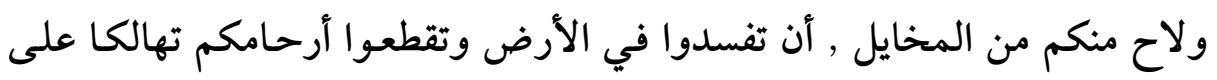

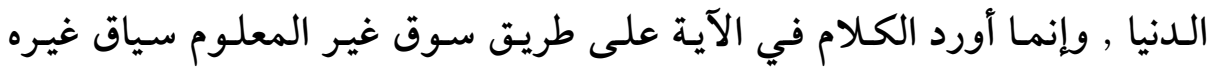

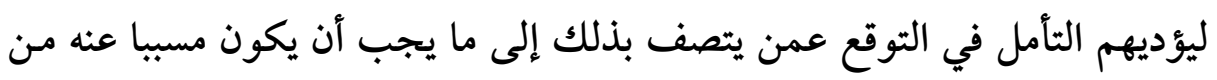

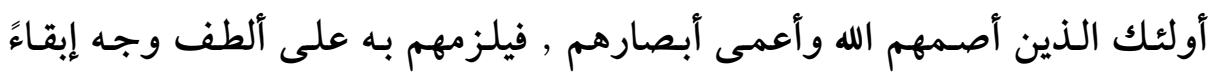

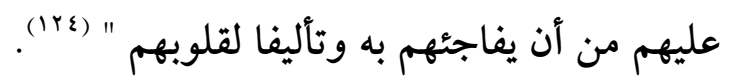

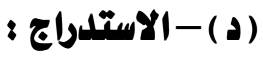
وهو فن يُقصد به استدراج المتلقي كي يقتنع بقناعة المتكلم , وذلك بطريق تقديم

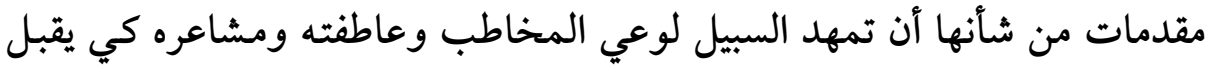


ما لم يكن يقبله من آراء وأفكار ومذاهب ....ويعرف نجم الدين بن الأثير الحلبي

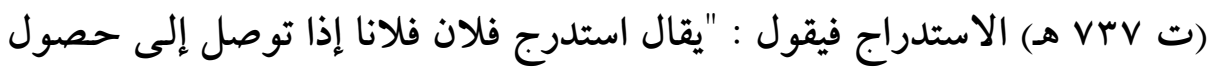

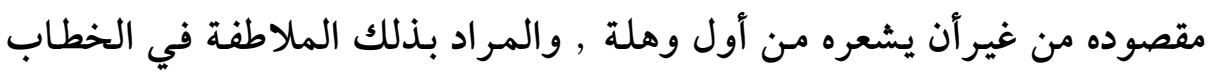

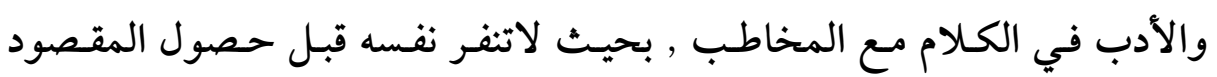

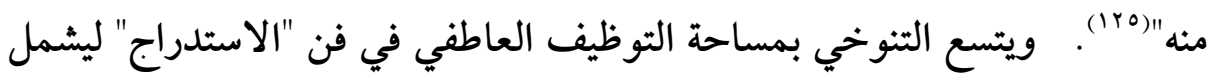

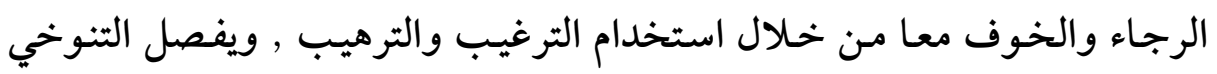

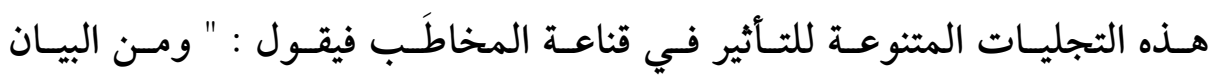

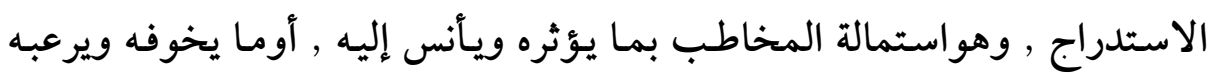

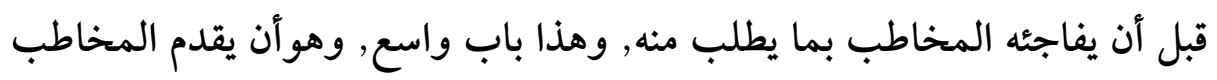

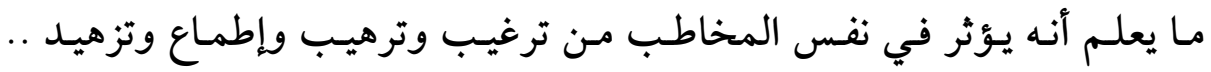

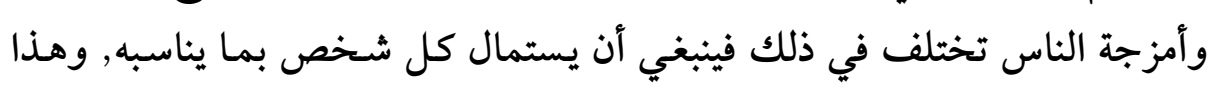

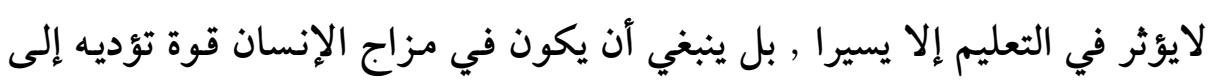

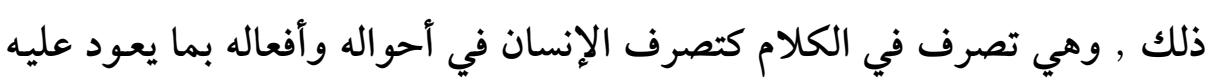

.....ويمثل التنوخي على ذلك بقوله تعالى : " اذهب إلى فرعون إنه طغى فقول له آله

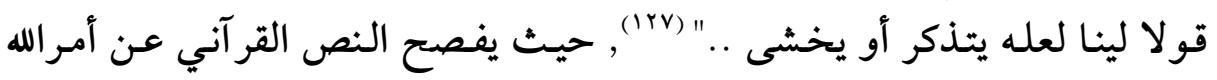

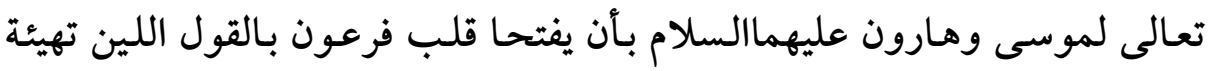

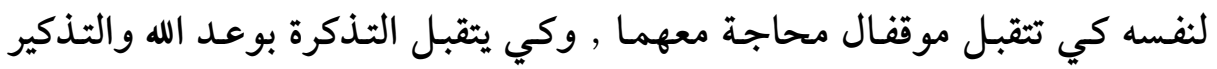

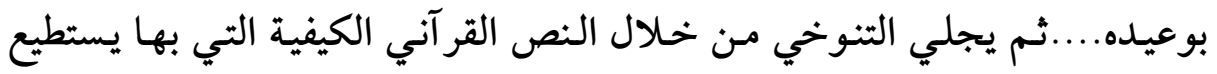

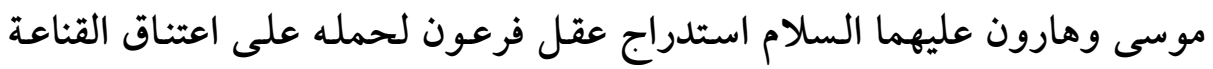

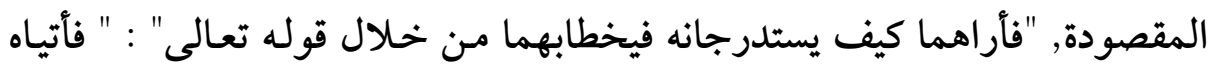

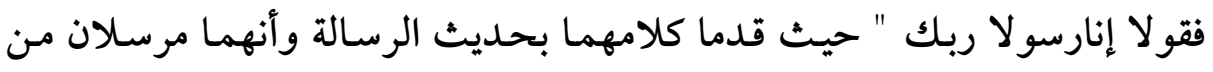

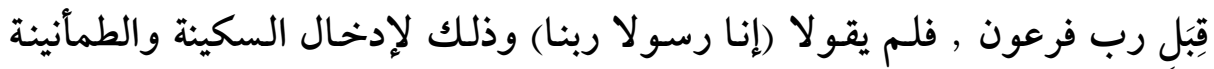

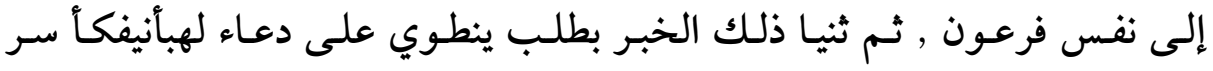

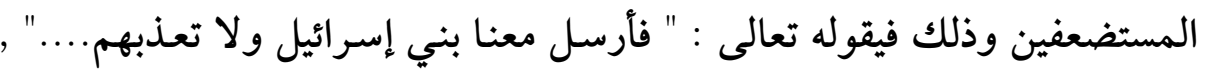


ثم أرد فاطلبهما بـ "قد جئناك بآية من ربك" وليس (بآية من ربنا) لتحقيق ذات

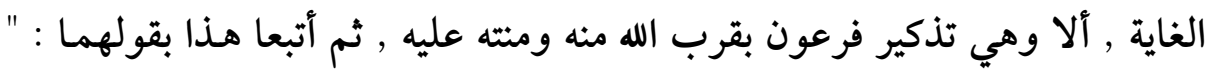

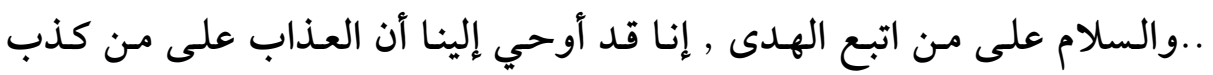

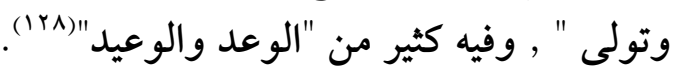

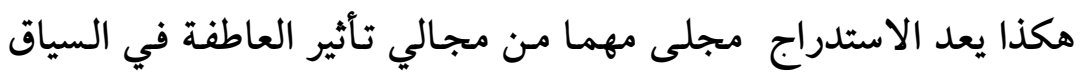

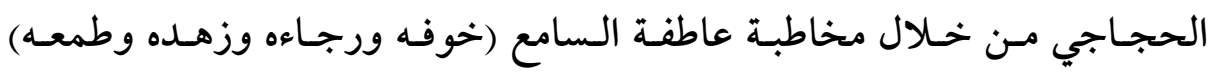

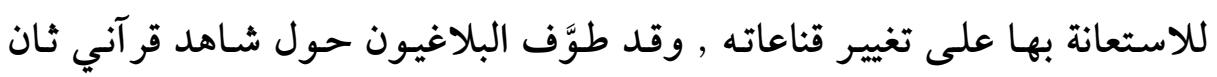

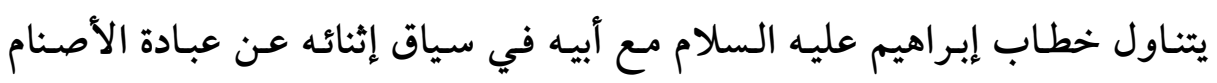

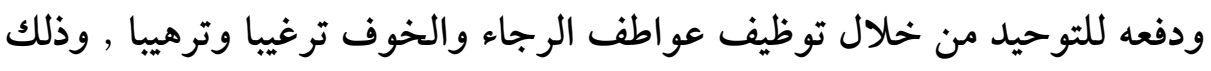

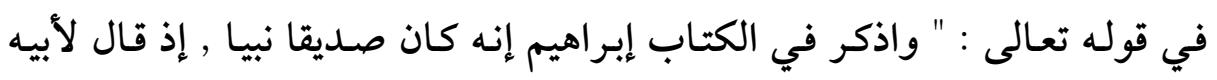

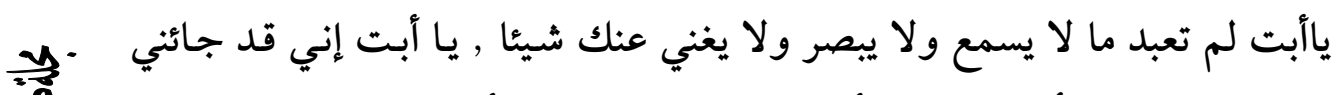

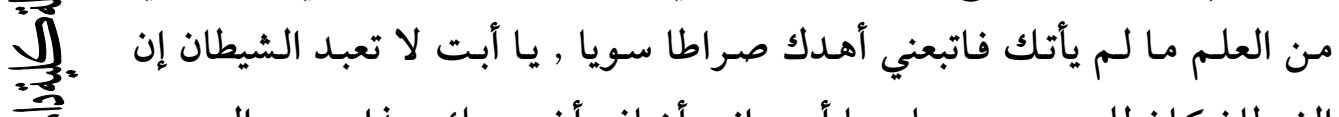

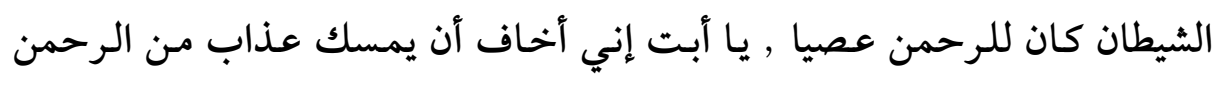

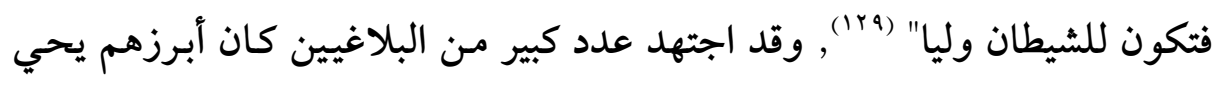

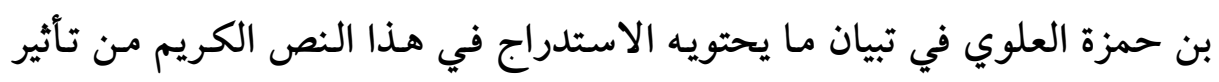

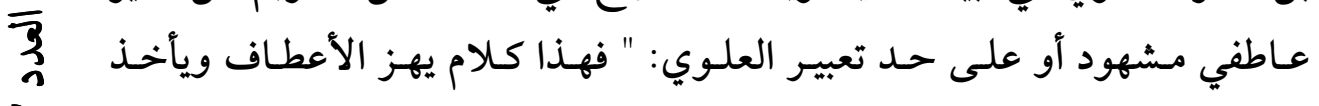

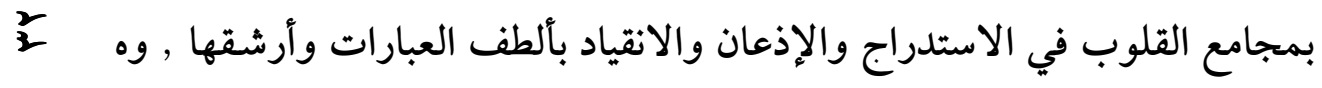
ومشتمل على حسن الملاطفة من أوجه : أولا : فلأن إبراهيم صلوات الملاطة من اوجه : الله عليهلما أراد هدايةأبيه إلى الخير

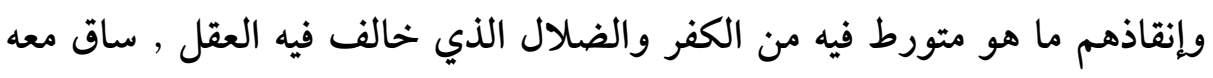

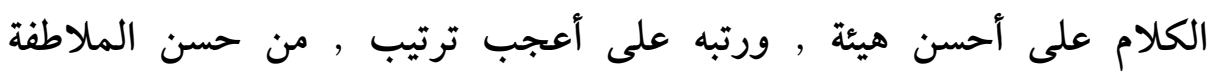

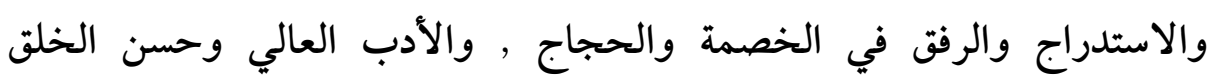

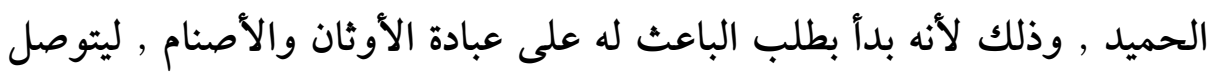

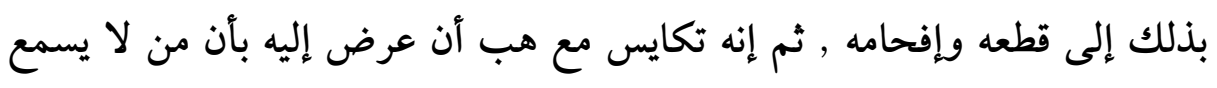

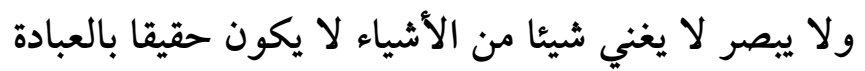


ثانيا : فلأنه دعاه إلى التماس الهداية من جهته على جهة الثنبيه والرفق به

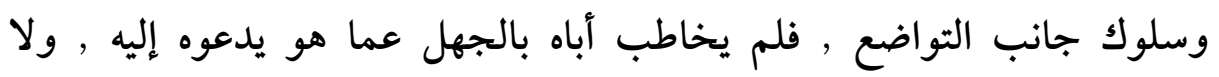

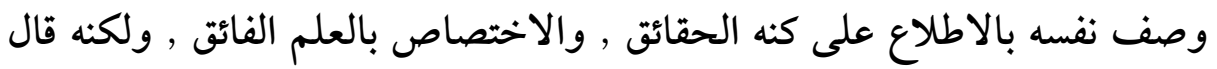

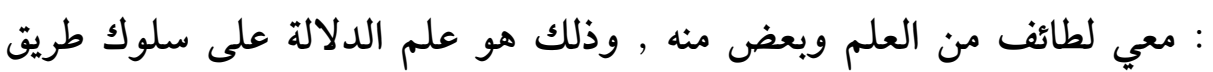

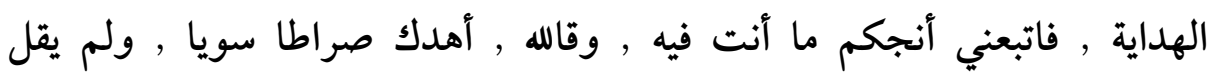

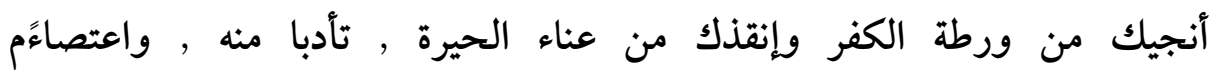
نمباداتهبقبيحكفره , وتسامحا مع ذكر ما يغيظه .. مأل

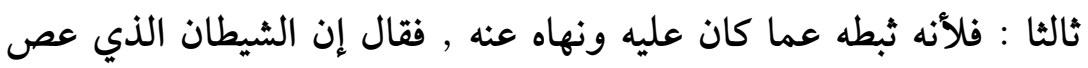

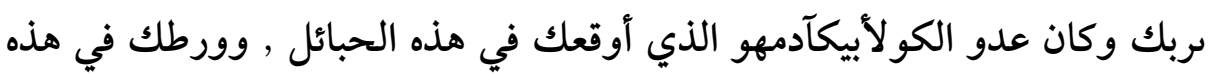

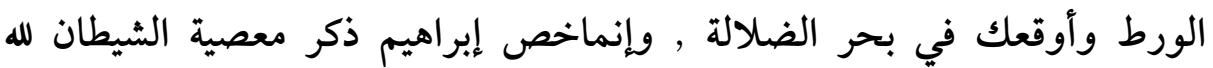

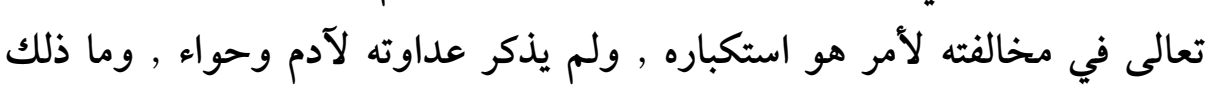

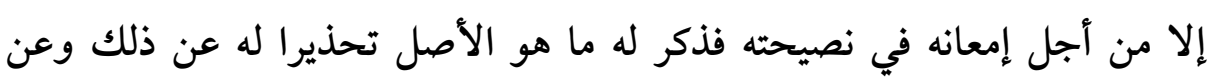

$$
\text { مواقعته ... }
$$

رابعا : فلأنه خوَّفه من سوء العاقبة بالعذاب السرمدي , ثم أنه لم يصرح

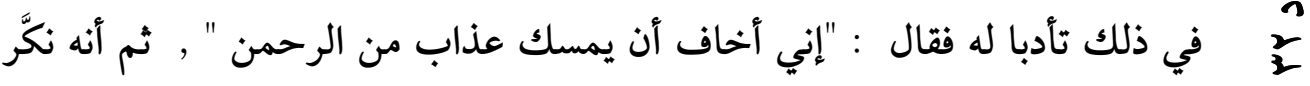

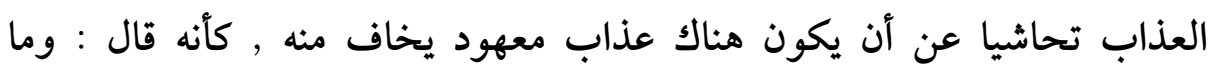
يؤمنك إن بقيت على الكفر أن تستحق عذابا عظيما عليه....

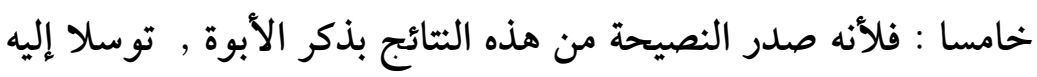

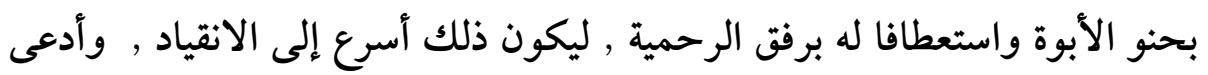

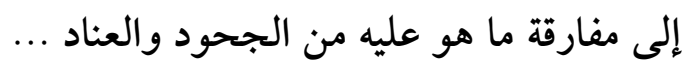

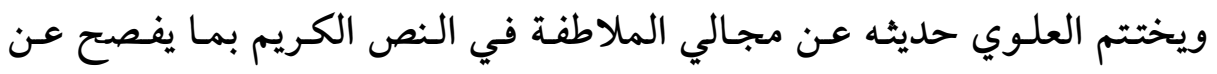

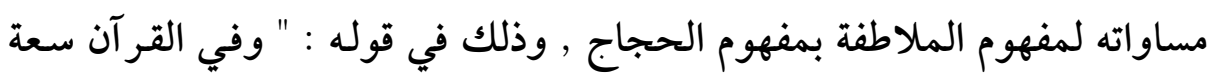

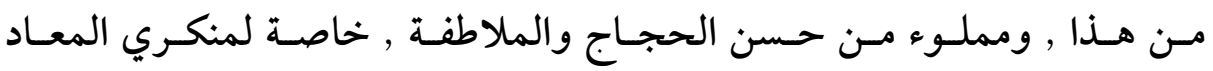


الأخروي , وعبادي الأصنام والأوثان , فإن الله تعالى نعى عليهم فعالهم وسجل

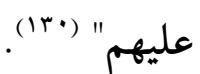

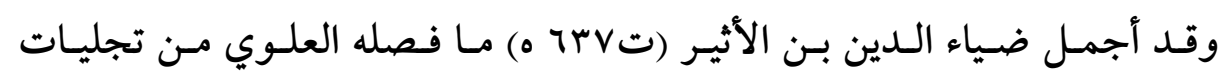

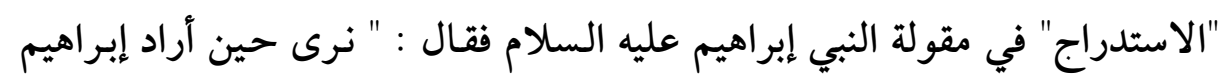

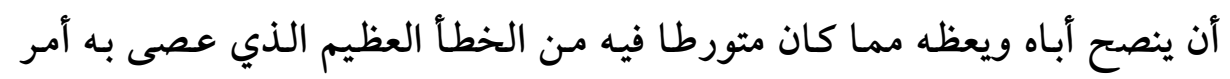
العقل , كيف رتب الكلام معه على أحسن اتساق وانتظام مع استخدام المجاملة

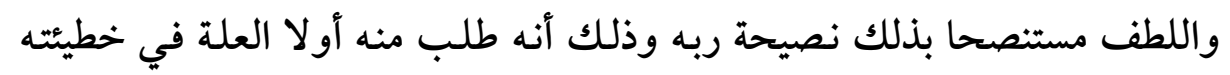

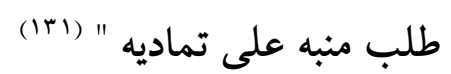
وقـد فطن علمـاء الحجـاج لأثر الخطاب العاطفي في تكريس العملية

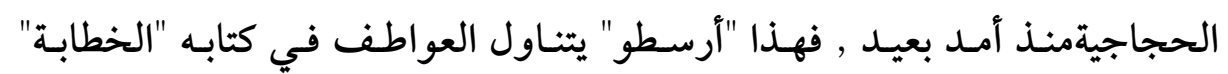

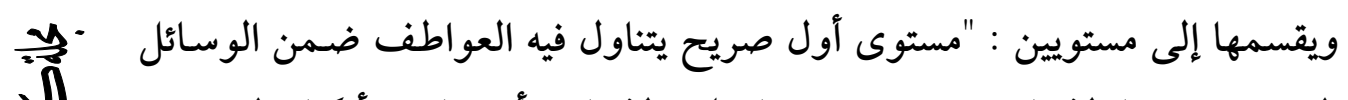

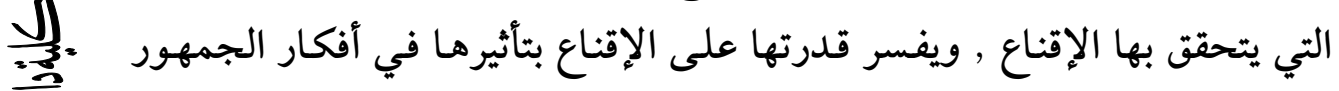

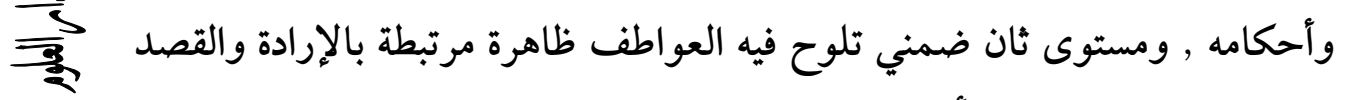

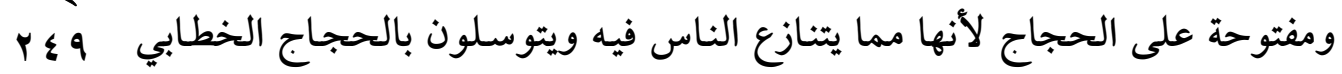

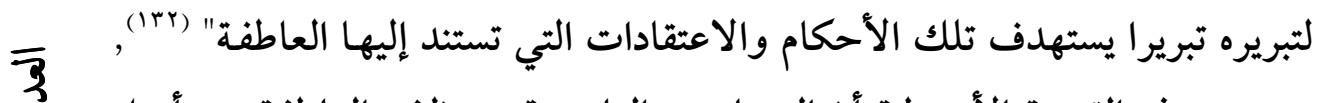

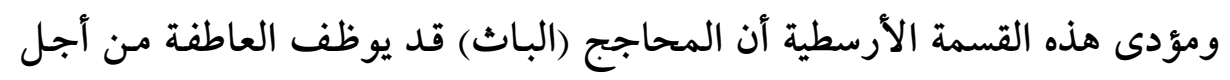

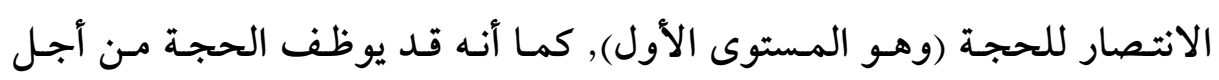

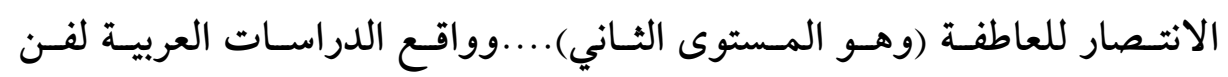

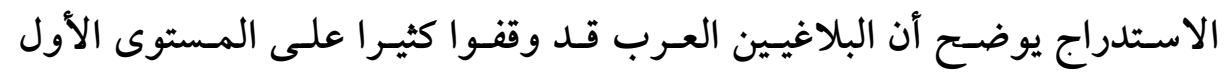

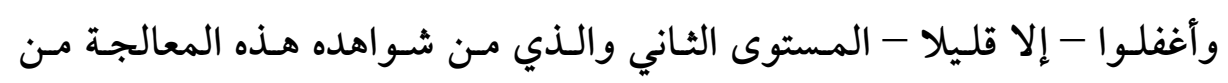

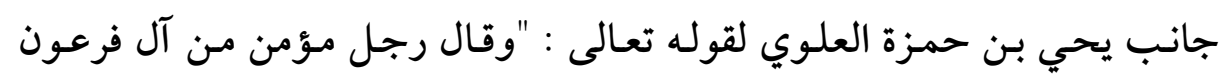

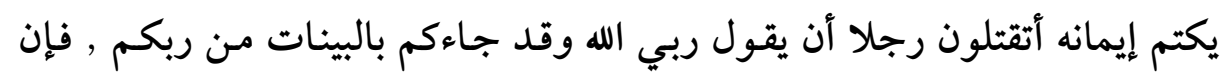

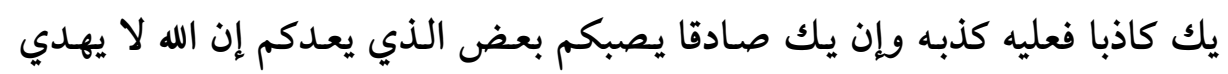

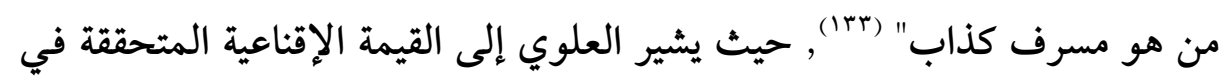

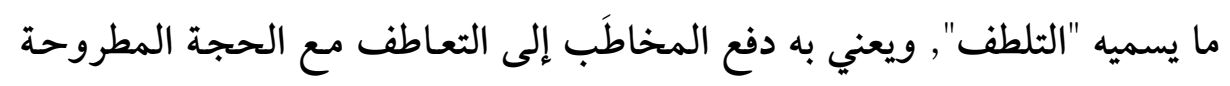


عن طريق تغليف هذه الحجة بعبارات تقترب من عاطفة المخاطب وتلامس مشاعره , رغم ما قد يتحقق في هذه العبارات من تقويض ظاهر للحجة وإضعاف ملحوظ لأركانها إلا إن هذا الضعف الظاهر في الحجة ينطوي على فلى قوة كامنة

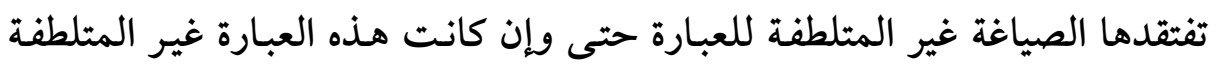
تحقق - في الظاهر - تدعيما للحجة المطروحة لا تحققه العبارة المتلطفة....كما

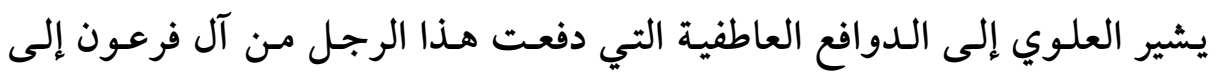

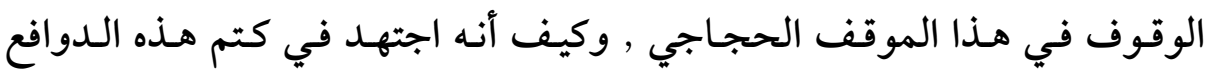

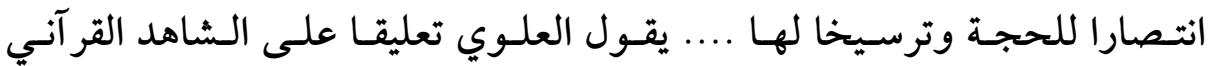

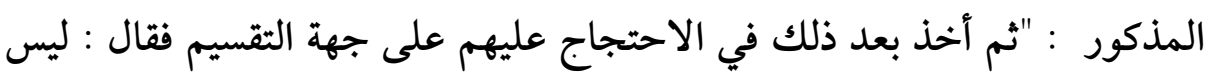

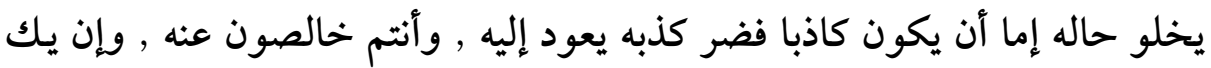

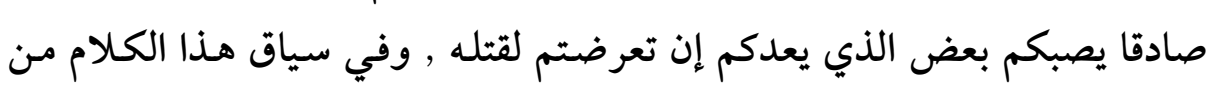

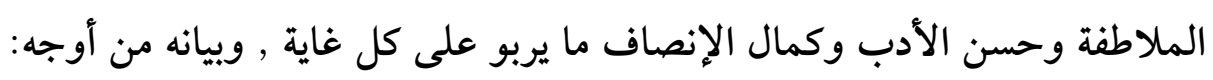

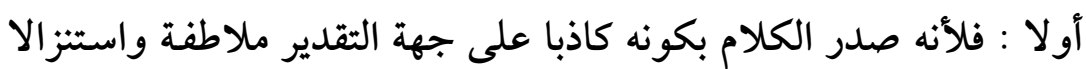

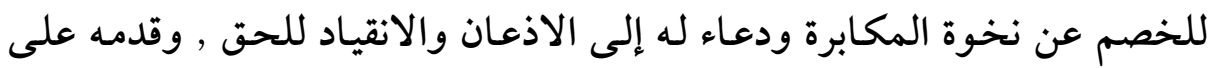

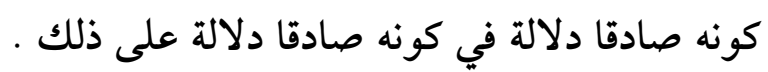

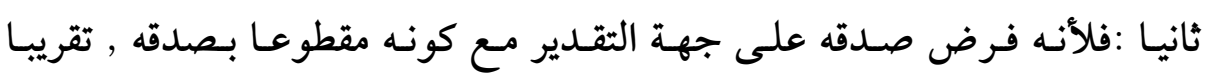

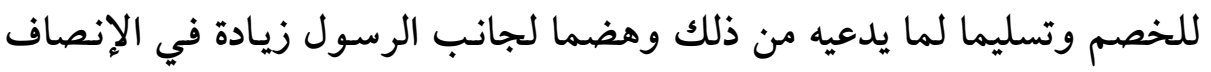

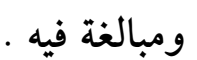
ثالثا : فإنه أردفه بقوله : يصبكم بعض الذي يعدكم , وإن كان التحقيق أنه يصيبهم كل ما يعدهم به لا محالة , من أجل الملاطفة أيضا .

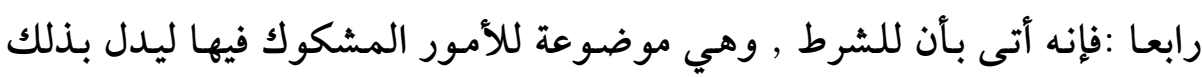

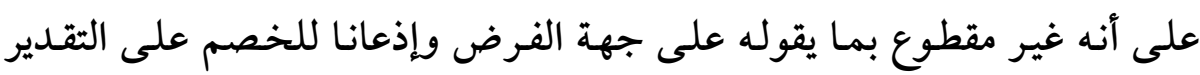

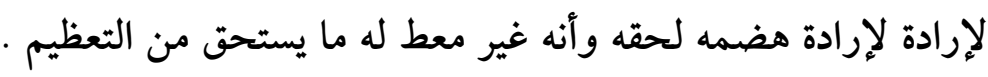




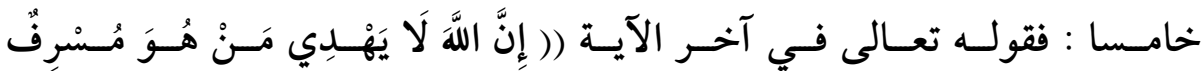

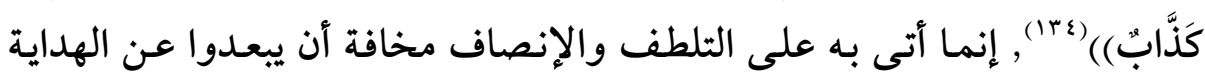

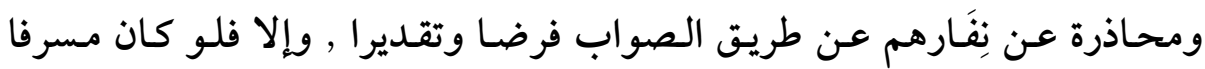

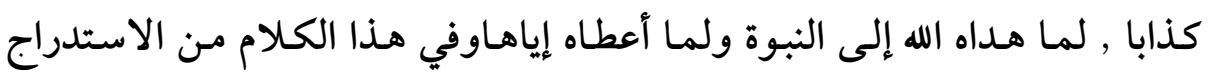

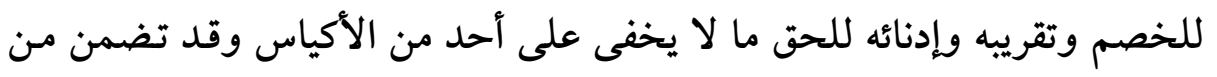

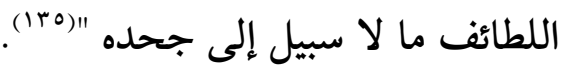

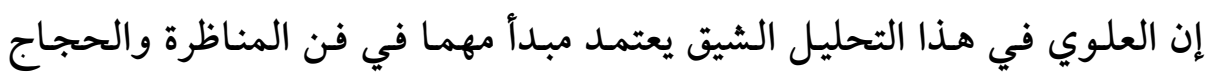

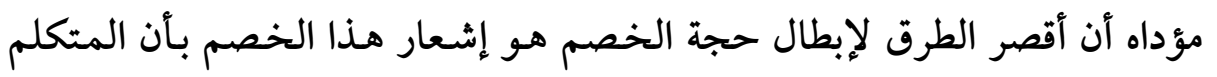

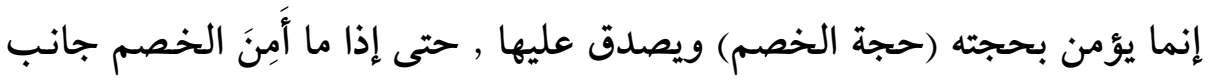

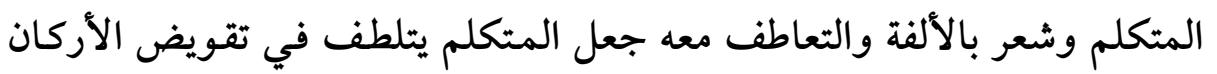

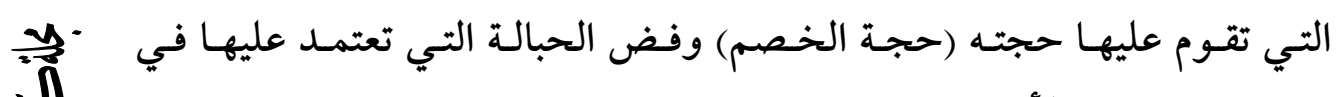
疍.

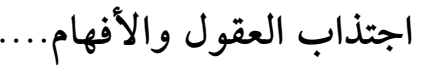

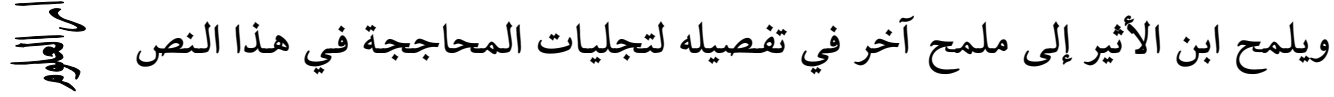

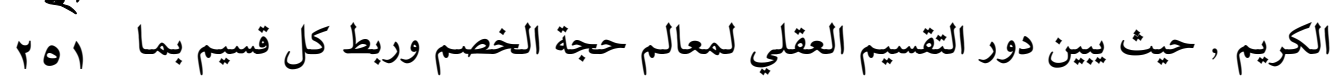

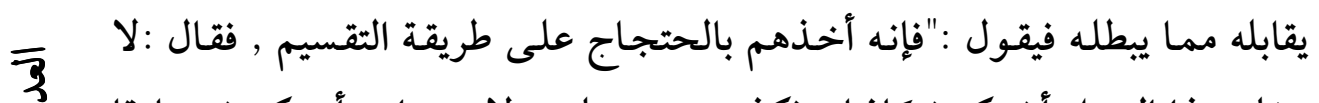

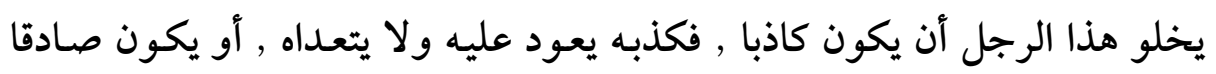

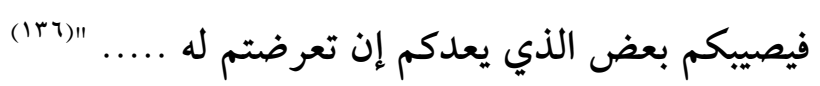

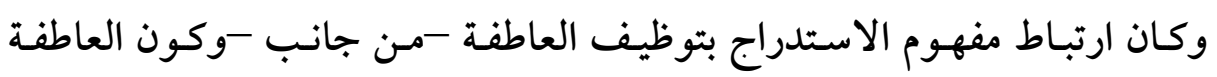

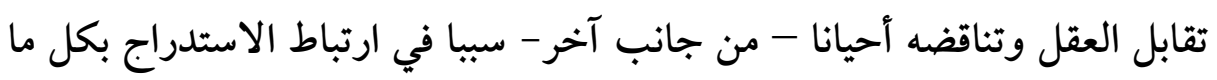

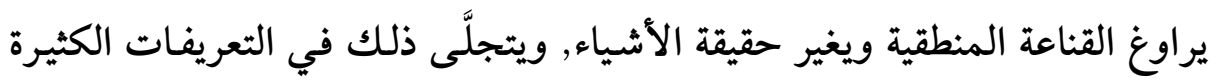

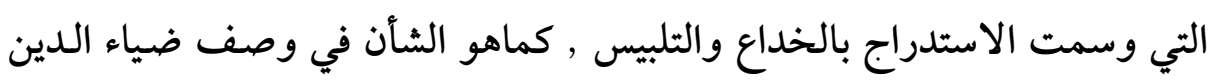

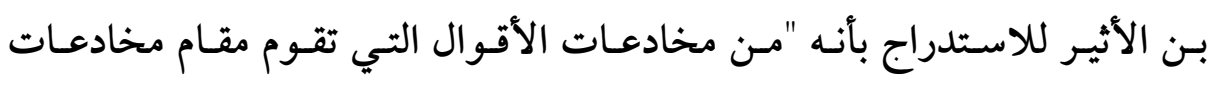

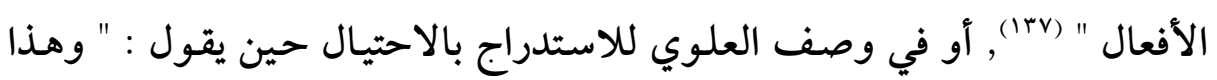

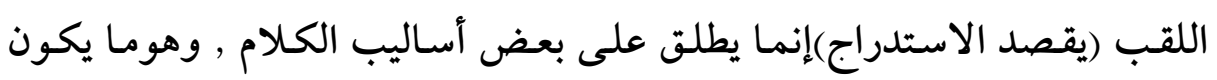

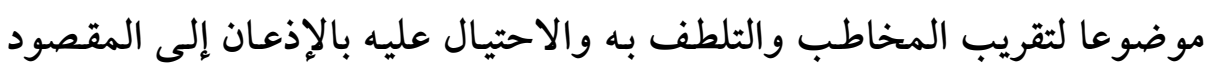


منه ومساعدته بالقول الرقيق والعبارة الرشيقة, كمايحتال علخصمهعندالجدال

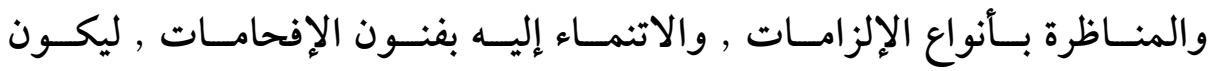

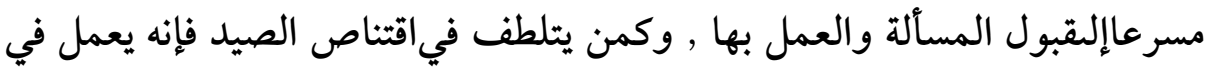
الحبالة كل حيلة ليكون ذلك سبيلا إلى مايقصده من الاصطياد , فهكذا مانحن

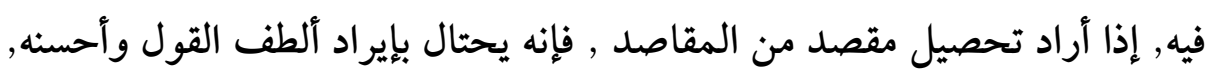
فماهذا حاله من الكلام يقال له الاستدراج " (1+1).

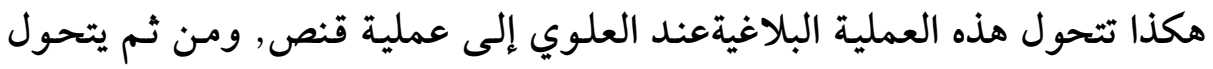

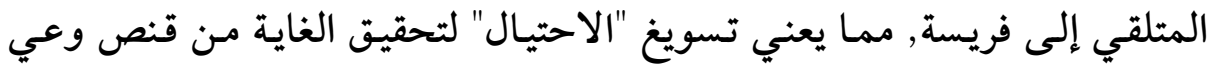

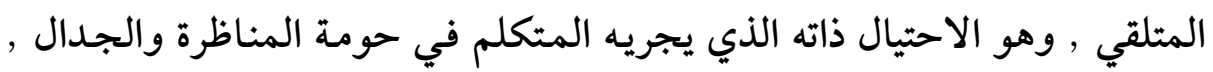
عن طريق مايسميه العلوي "فنون الإفحامات". .

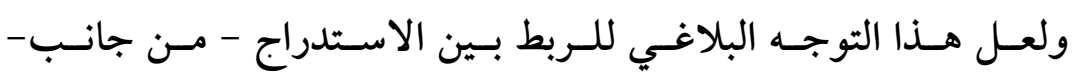

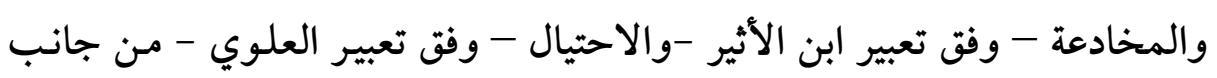

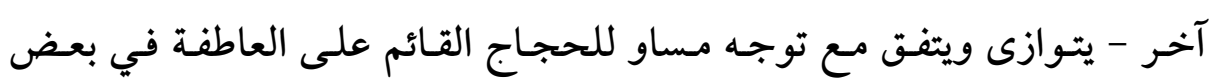

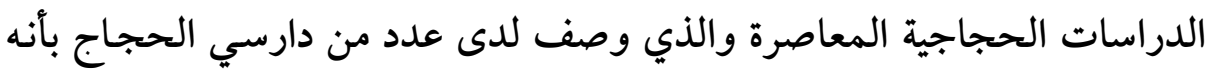

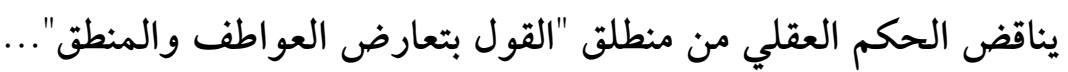

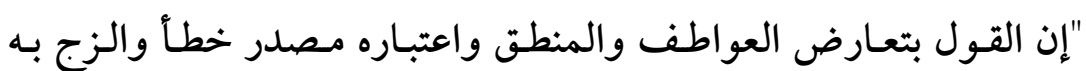

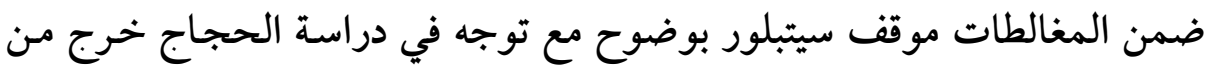

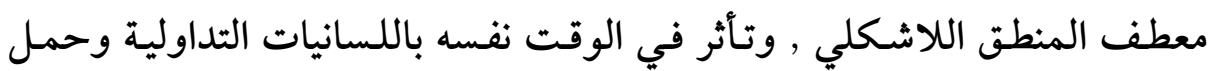

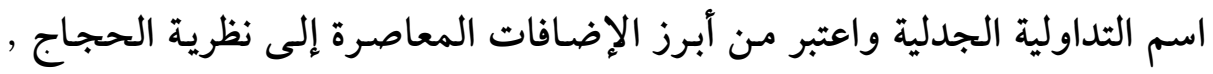

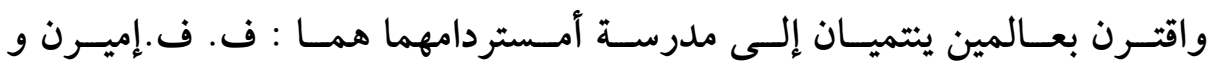

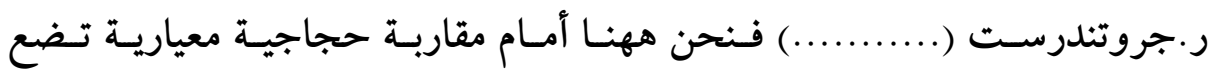

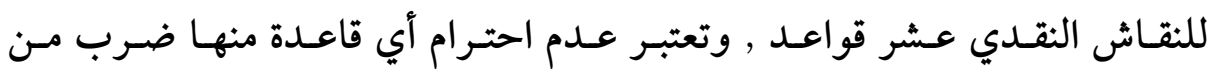

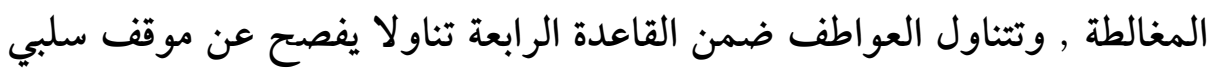

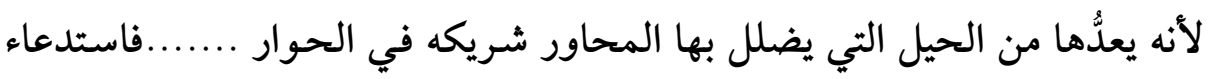


العواطف في هـذه المقاربـة يعـد بـديلا غيـر شـرعي لمـا ينبغي أن يكسون عليهـ

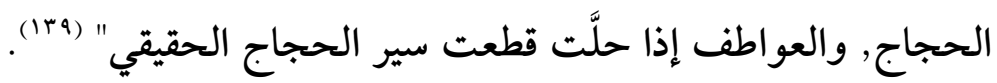

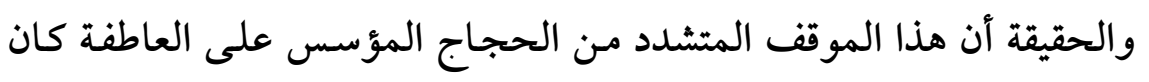

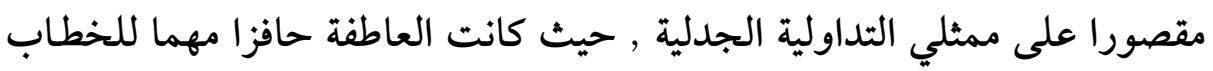

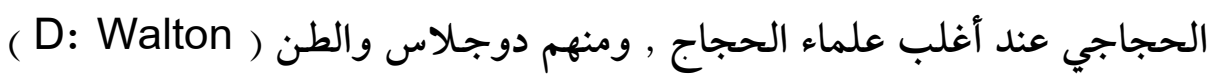

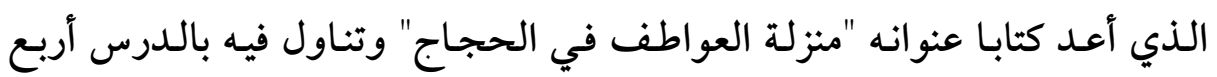

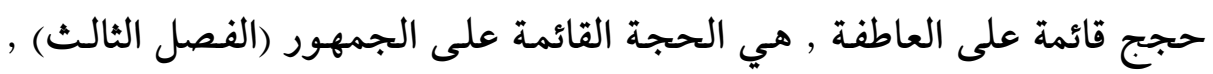

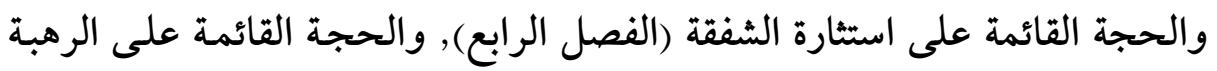

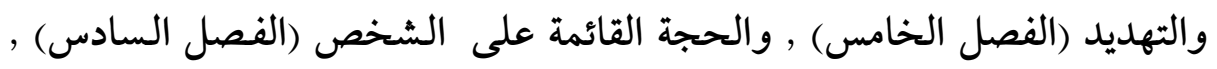

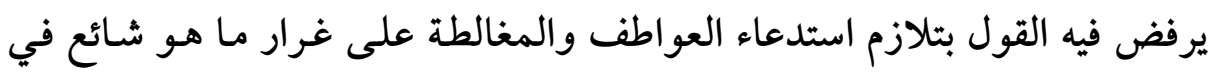

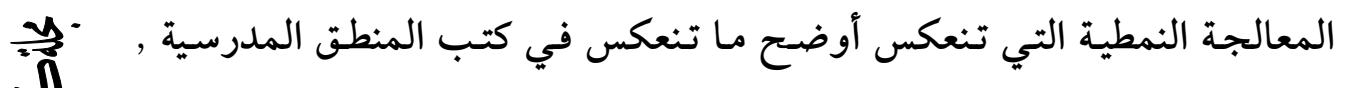

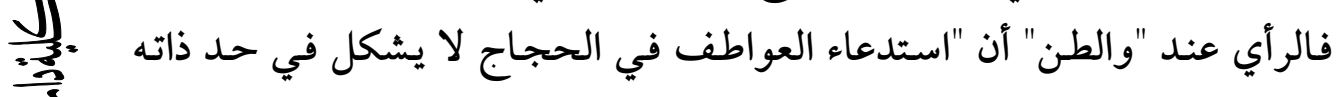

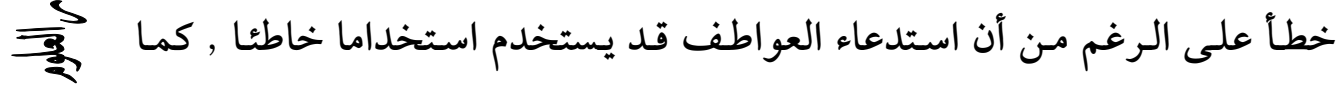

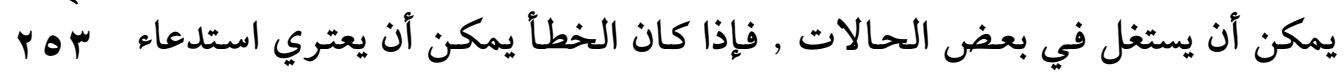

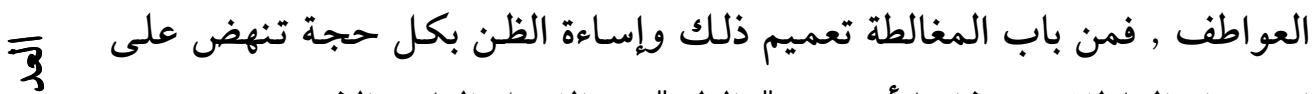

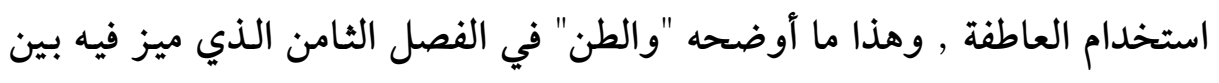

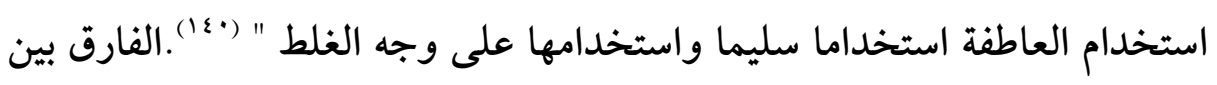

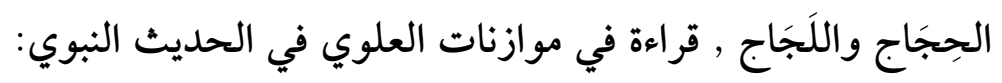

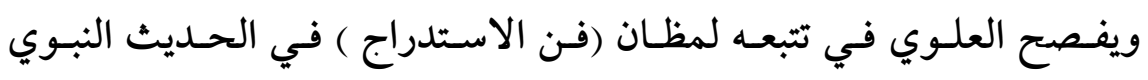

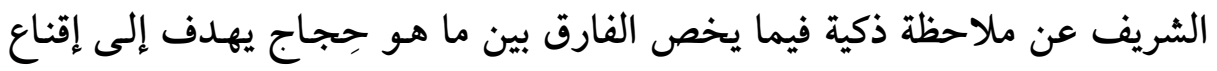

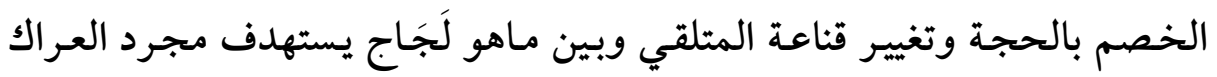

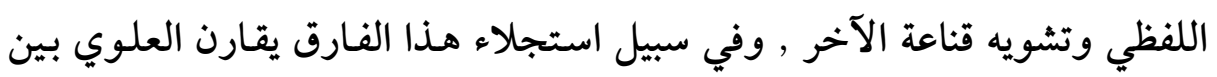

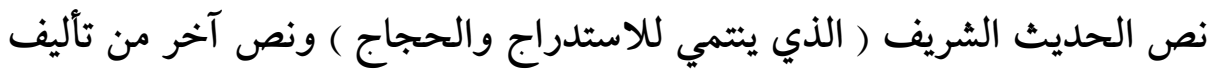
العقل الافتراضي للعلوي ( والذي يتتمي للجاج والجدل العقيم) .... 


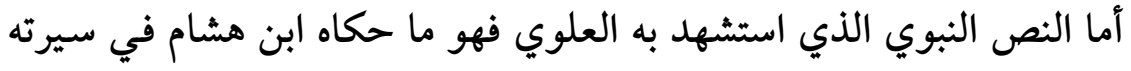

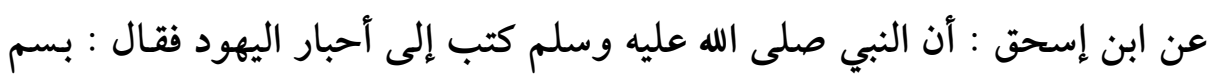

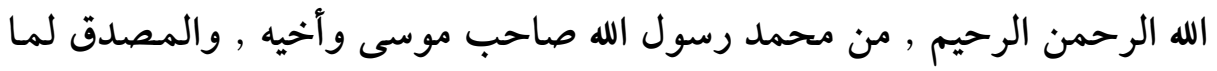

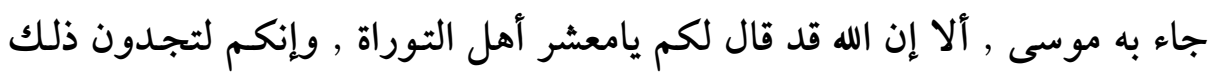

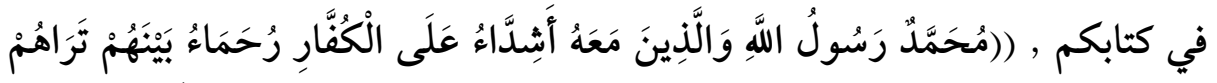

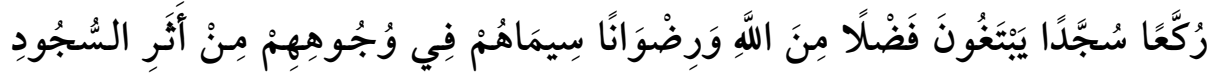

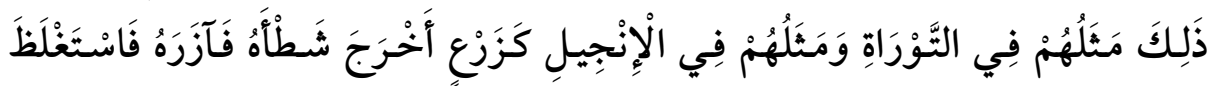

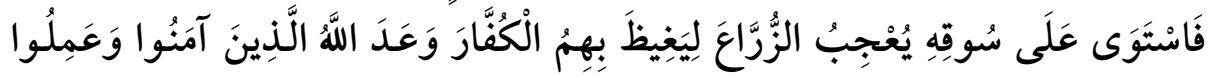

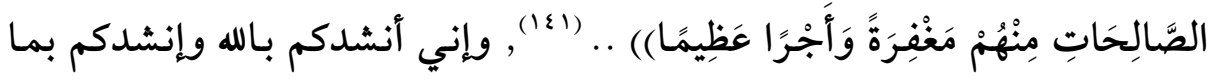

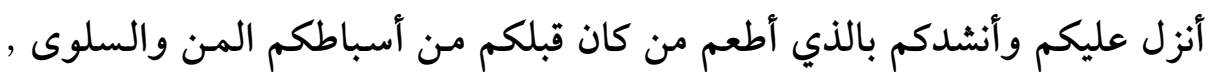

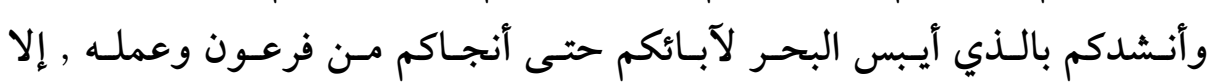

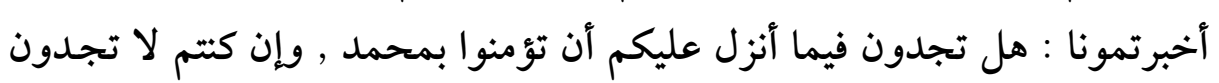

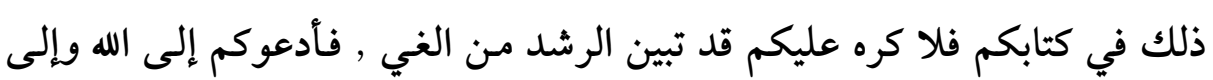

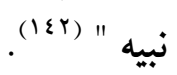

وأمـا النص الافتراضي الذي وضعه العلوي شـاهدا على اللجاج والجدل

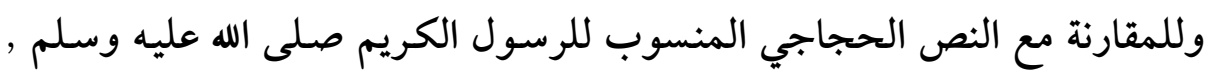

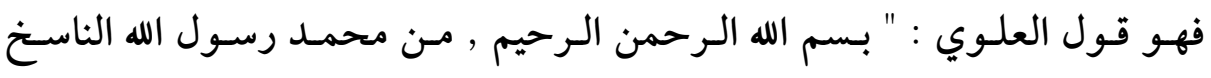

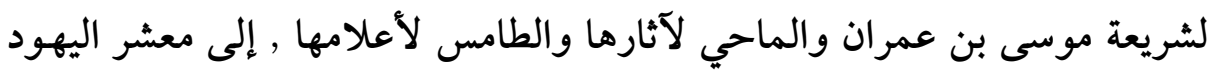

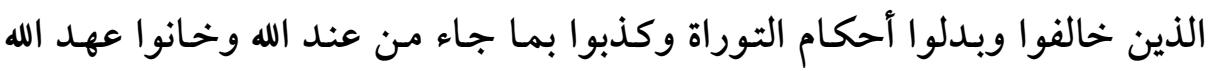

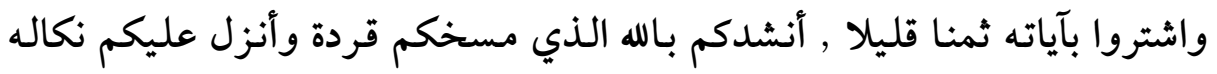

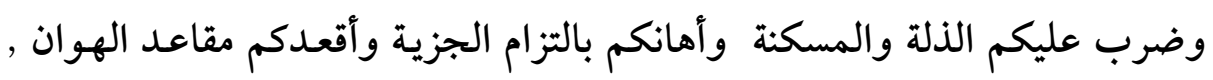

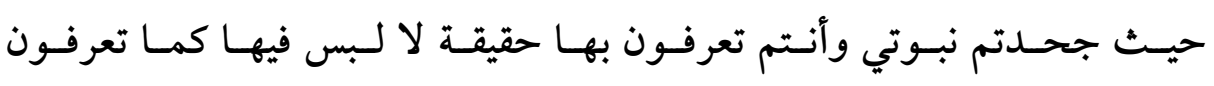


ويوازن العلوي بين النصين , فيشير إلى أن النص الأول قد احتوى عددا من

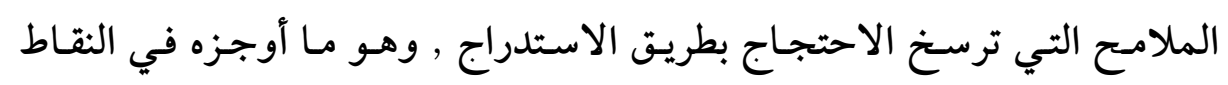
التالية : أولا : أنه صدر كتابه بقوله : "صاحب موسى وأخيه" ..وإنما فعل ذلك إزالة

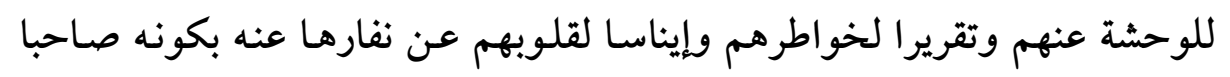

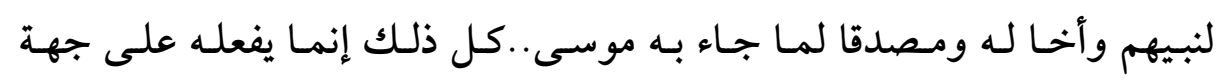

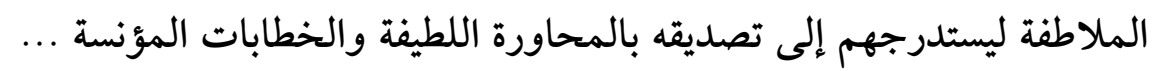

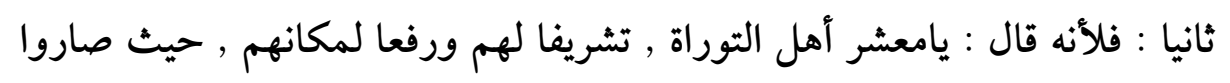

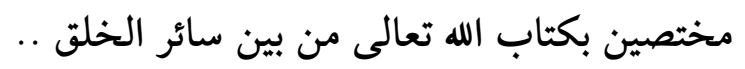

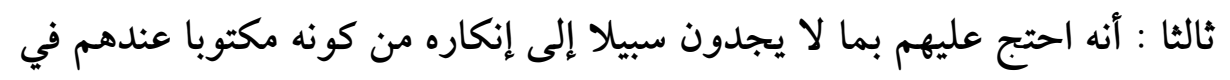

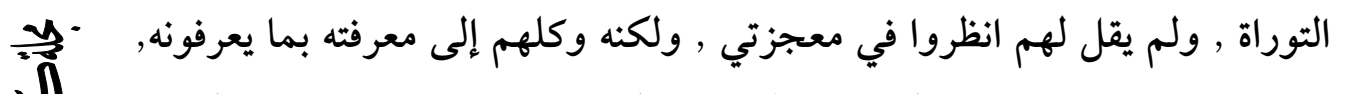

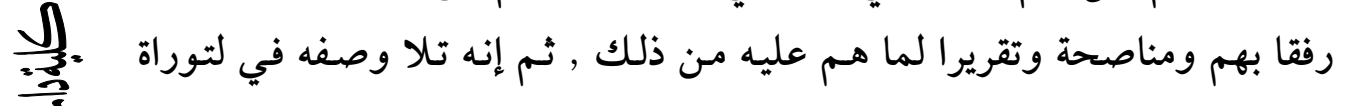

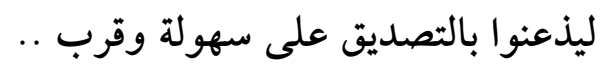

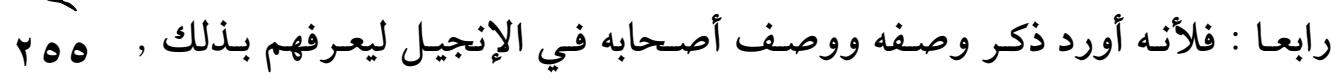
亨 إيناسا لهم وتقريبا.. - إنان. خامسا : فلأنه ذكر المناشدة تذكيرا لهم بالآلاء العظيمة والنعم المترادفة .....أنه

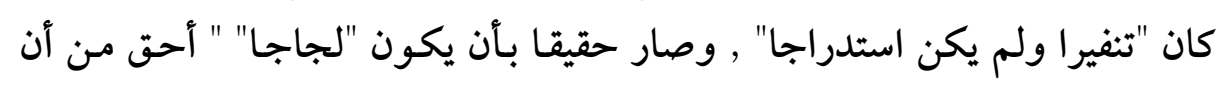

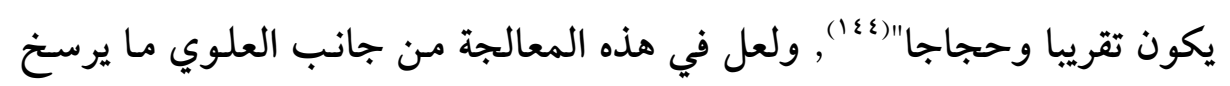

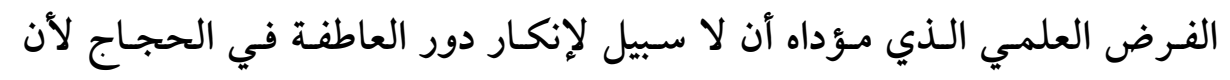

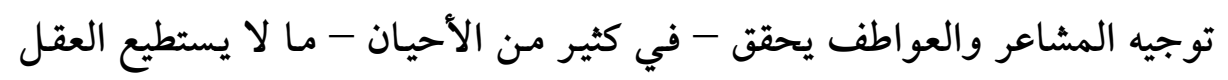

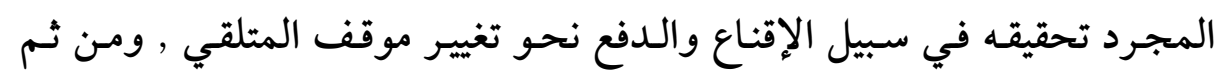
كانت دراسات البلاغيين العرب لفن الاستدراج مجلى مهما من مجالي الحجاج

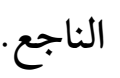


وهو من مخترعات حازم القرطاجني , وقد عرفه فقال : "هو تذييل أواخر

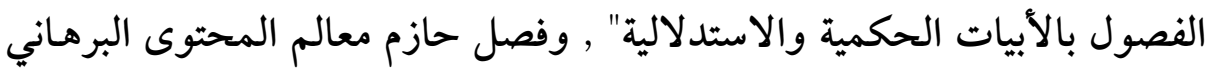

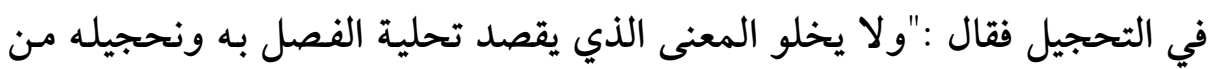

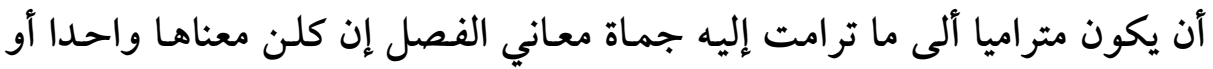

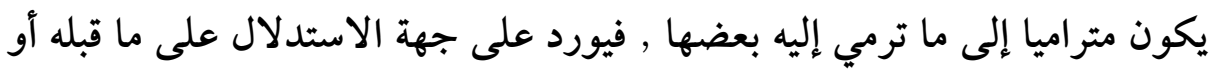

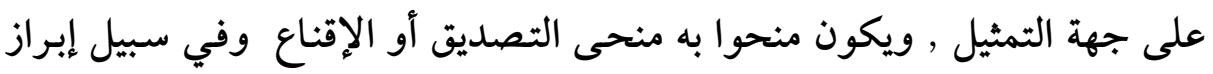

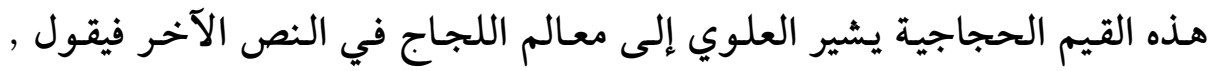

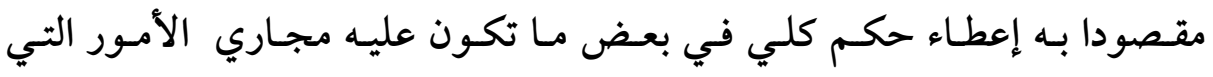

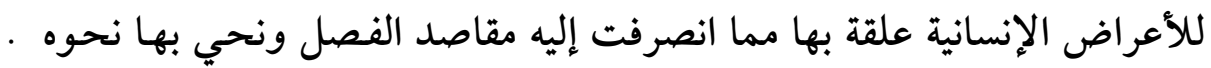

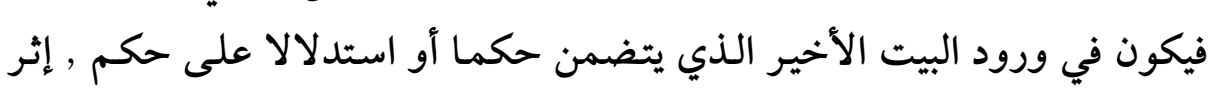

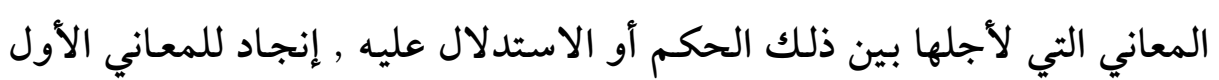

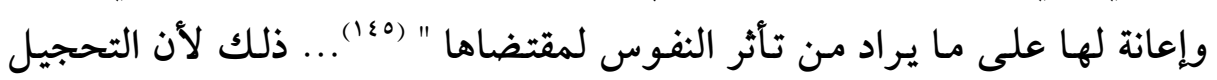

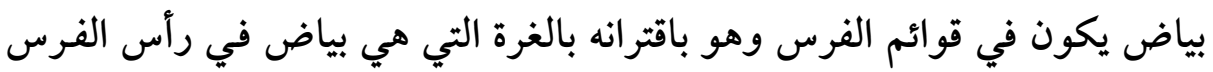

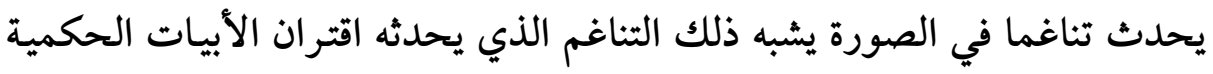

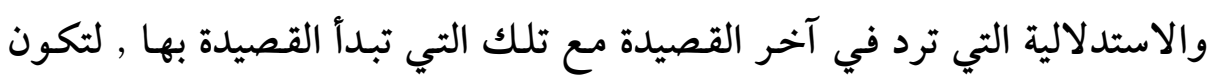
الأبيات الحكمية والاستدلالية بمثابة البرهان والدليل على مـا سبقها من أفكار

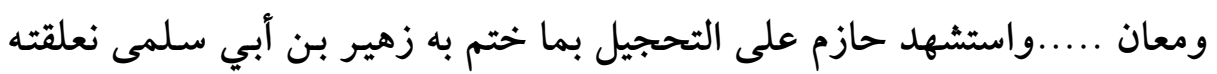

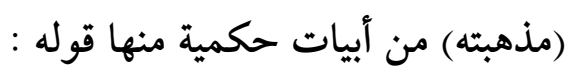

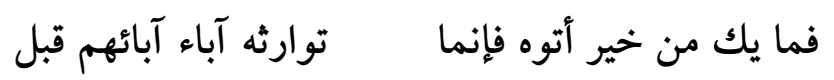

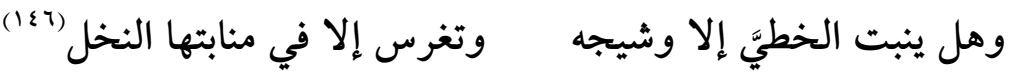

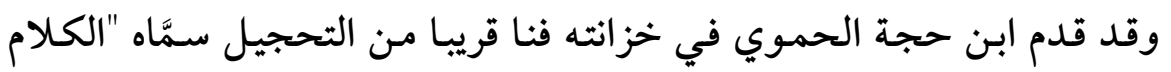

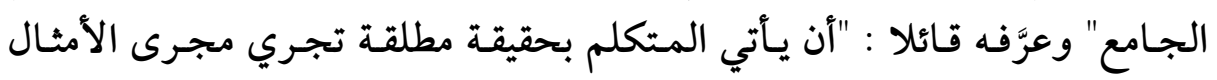

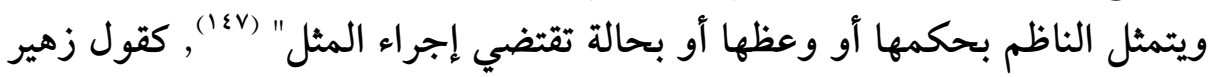




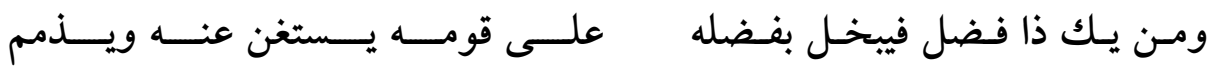

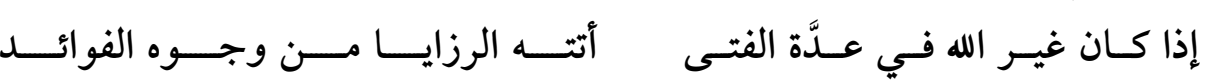

$$
\text { وقول أبي فراس : إذ فئان }
$$

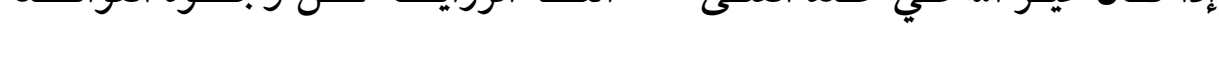

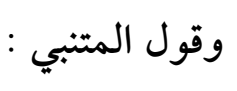

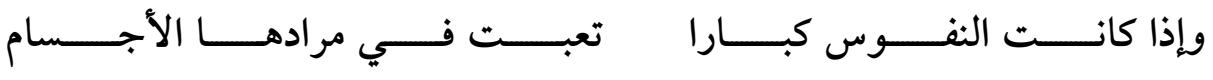

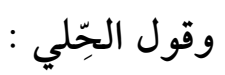

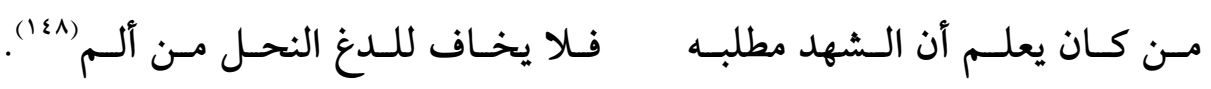

والفارق بين الكلام الجامع والتحجيل أن التحجيل أبيات حكمية ترتبط بآخر

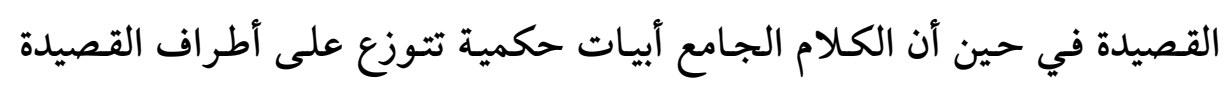

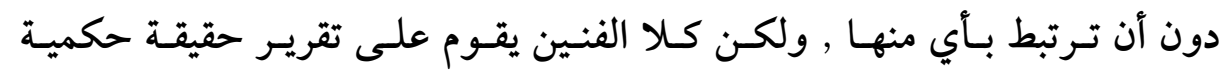

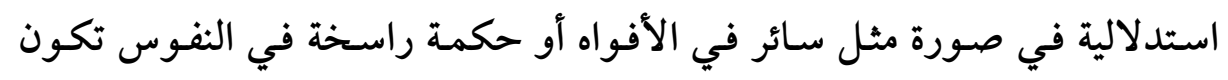

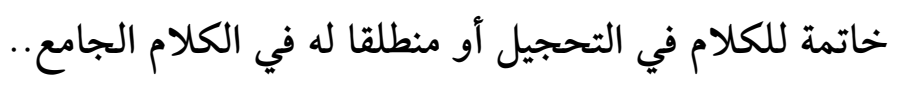

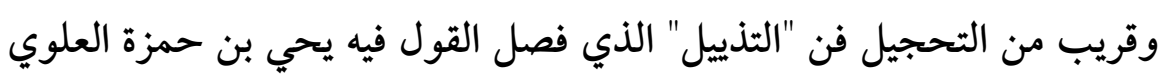

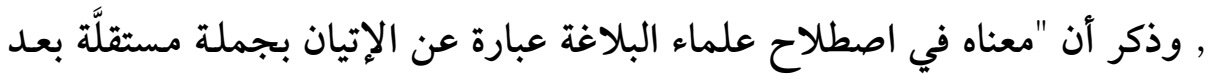

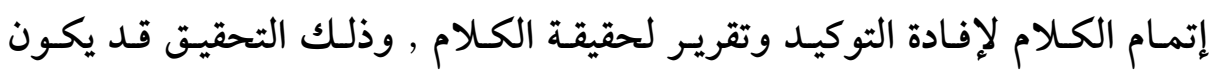
لمنطوق الكلام وتارة يكون لمفهومه"(14 1).

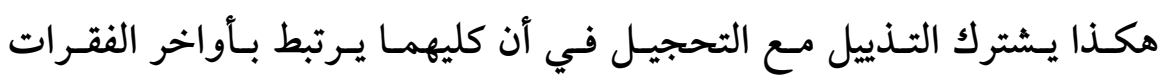

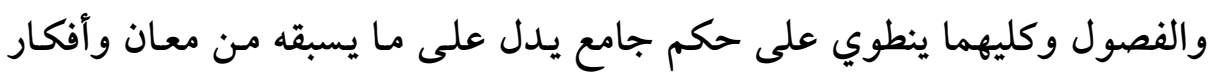

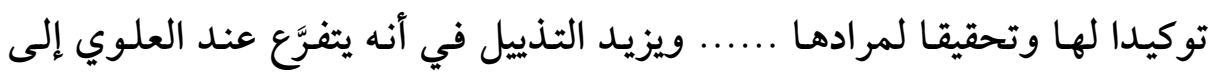


" الوجه الأول : أن يكون سوقه من أجل تأكيد منطوق الكلام , ومثاله قوله تعالى:

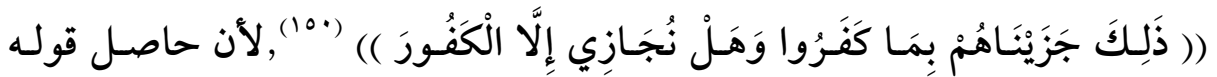

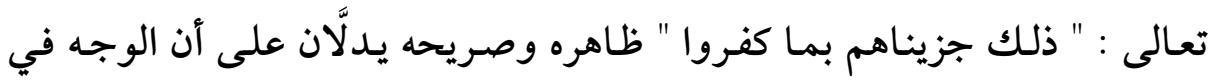

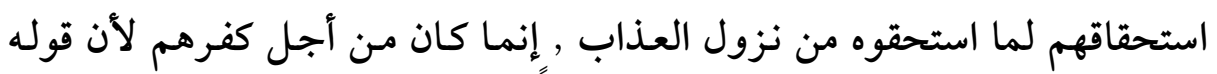

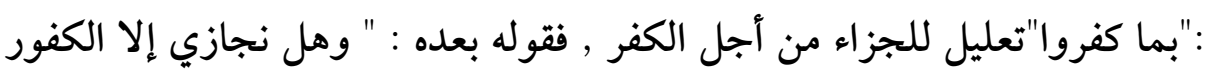

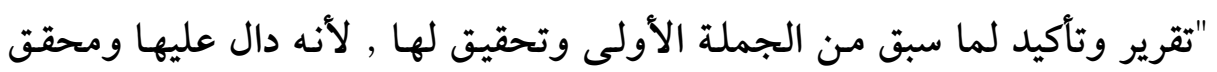
لفائدتها ..." (101). "الوجـه الثاني : أن تكـون الجملة الثانية مسوقة مـن أجـل تأكيد مفهوم

$$
\text { الكلام , ومثاله بيت النابغة: }
$$

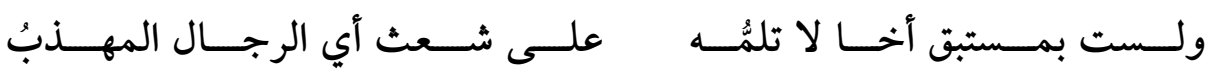

فقوله : " ولست بمستبق أخا لا تلمُّه" دال من جهة مفهومه على نفي الكامل

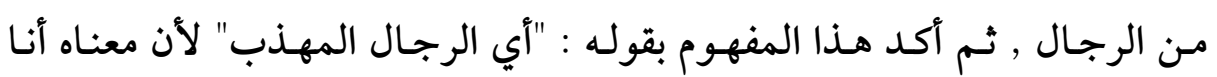

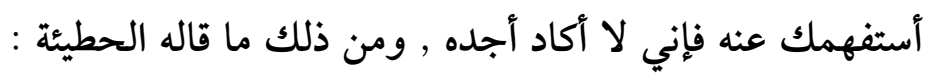

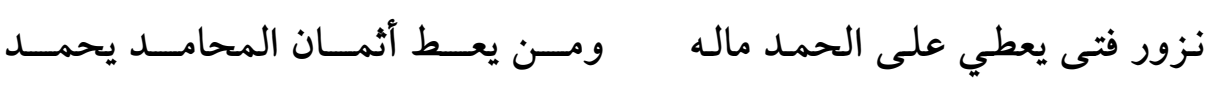
فمفهوم قوله :" يعطي على الحمـد ماله" أنه لا يعطي ماله إلا مـن أجـل أن

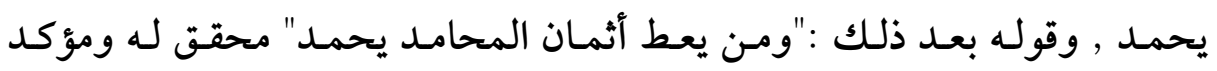
لفائدته " (10r). وقـد سبق أبـو هـلال العسكري إلى الحـديث عـن فـن قريـب مـن "التحجيل "الحيل

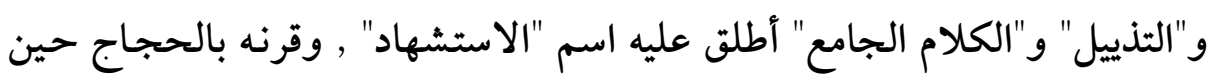

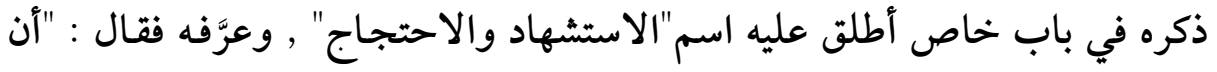

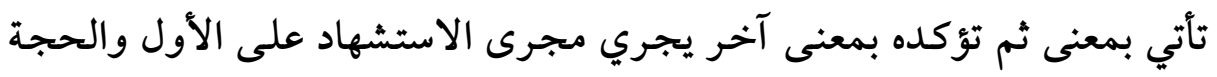

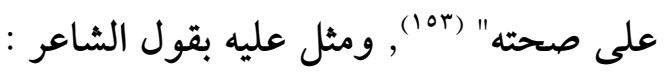




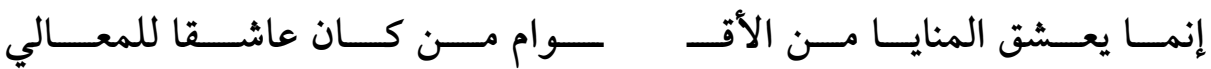

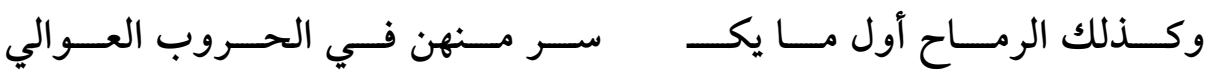

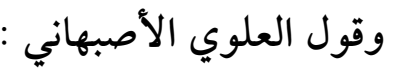

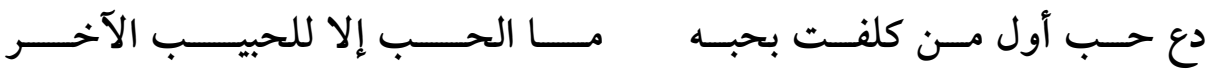

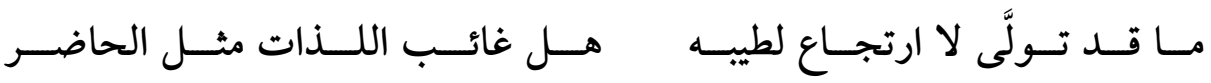

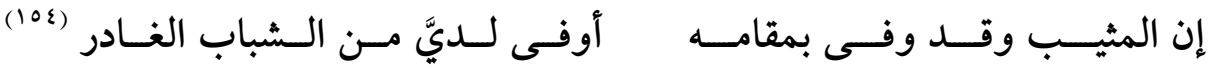

والاستشهاد بالنصوص الحكمية الموروثة أحد تجليات الحجج المؤسسة لبنية

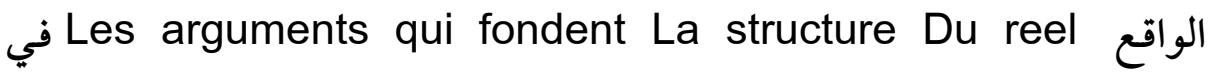

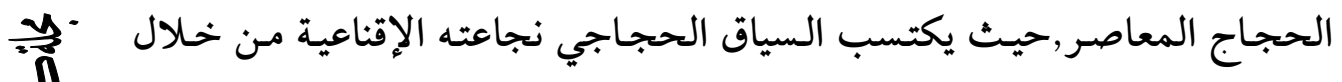

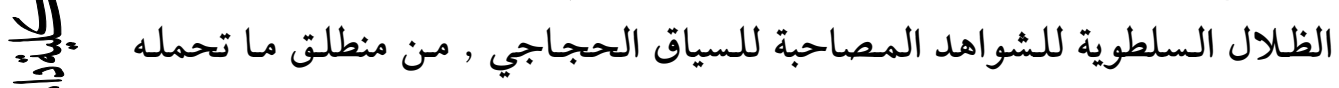

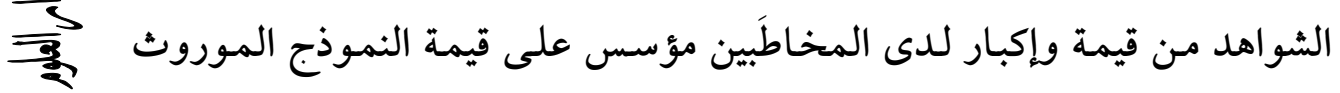
r०q الذي يصدر عنه الشاهد .. (100).

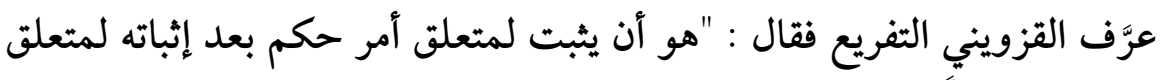

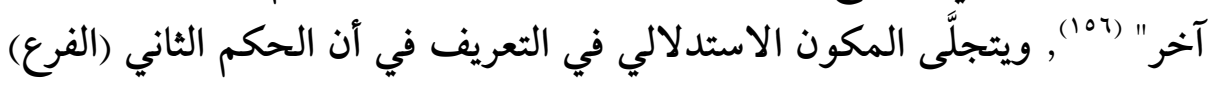

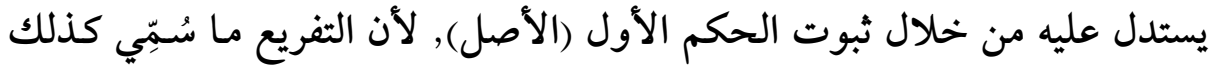

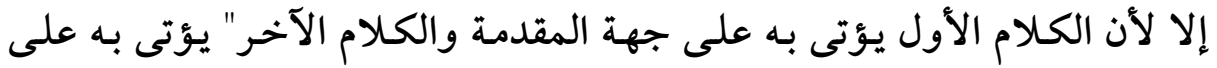

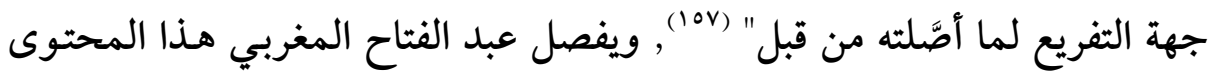

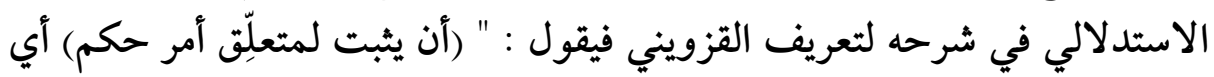

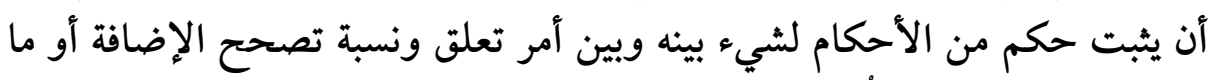

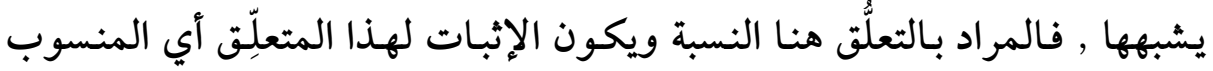

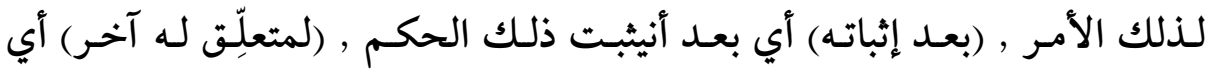

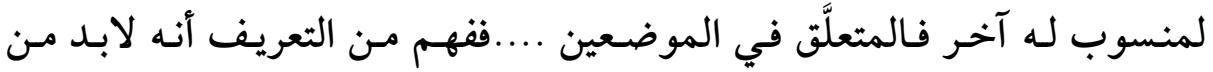


متعلّقين أي منسوبين لأمر واحد كغلام زيد وأبوه , فزيد أمر واحد وله متعلقان

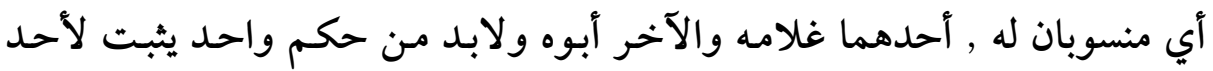

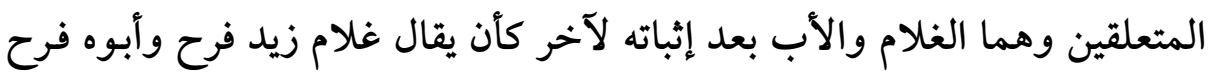

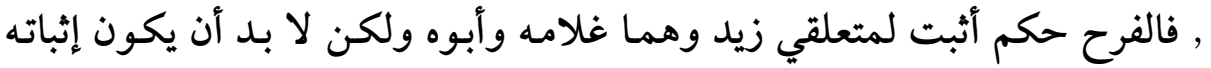

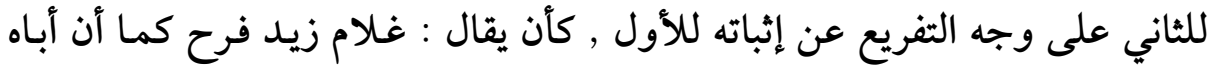

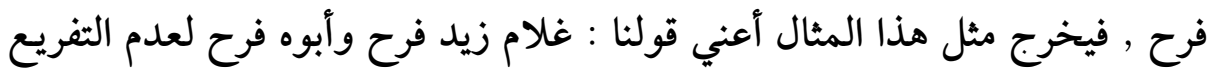
في الإثبات للثاني ولو اتحد الحكم فيهما " (101).

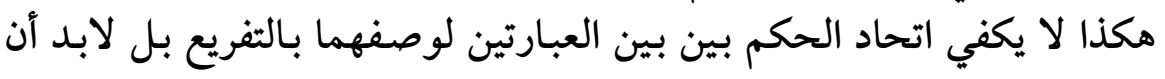

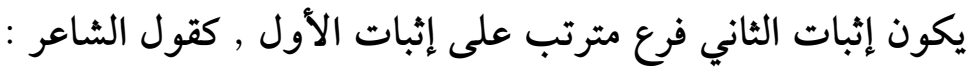

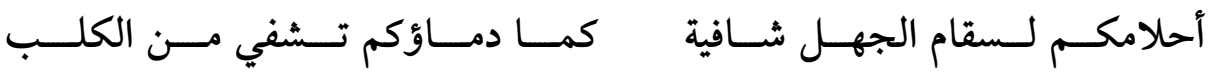

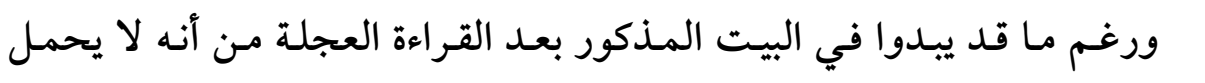

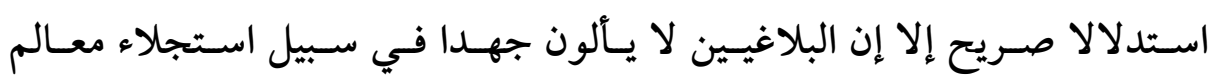

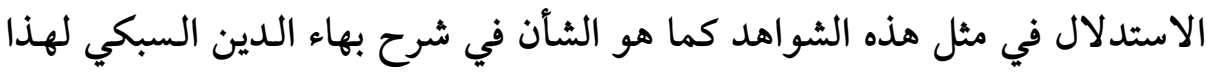

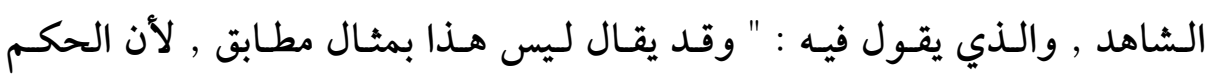

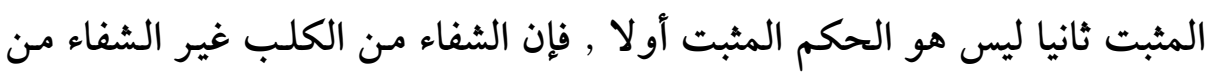

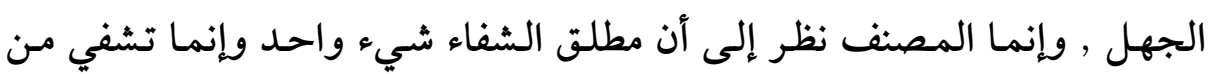

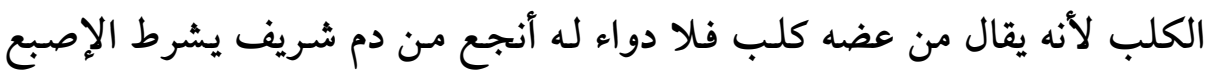

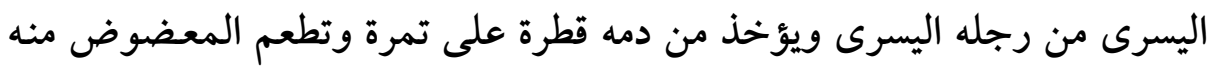

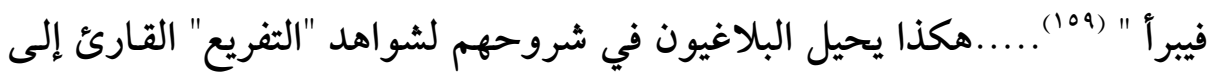

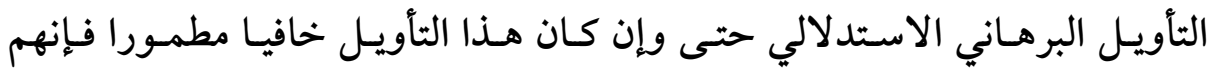
يجدُون في سبيل إبرازه وتفصيله.

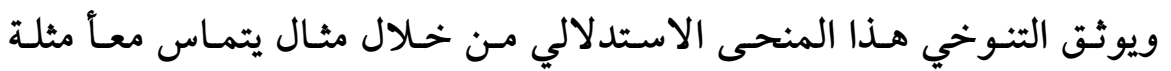

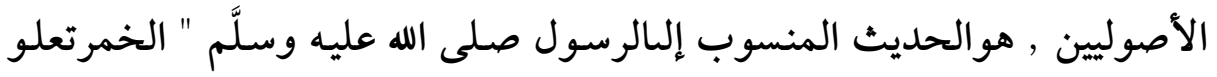
الخطايا كما أن شجرها يعلوعلى الشجر" ويذكر الثنوخي أن هنالك تفريعا أو تعقيبا 
بين علوِّ الخمر على الخطايا-من جانب -وارتفاع شجرة العنب وتسلقها على ماتى

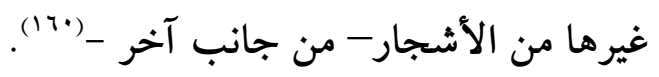

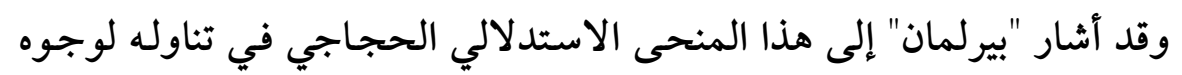

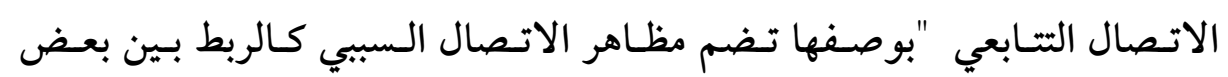

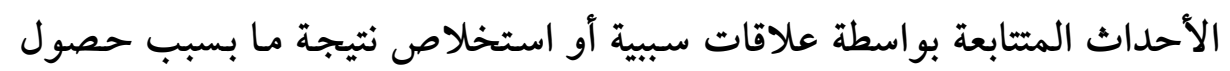

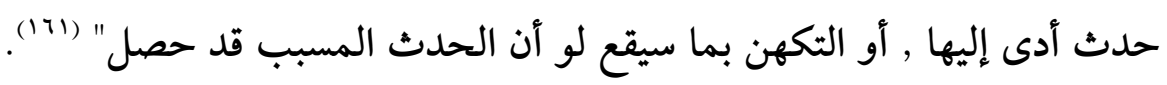

(ز) الإلهاب والتهييج :

وقد انفرد العلوي بذكر هذا الفن وقال في تعريفه :" وأما في مصطلح علماء

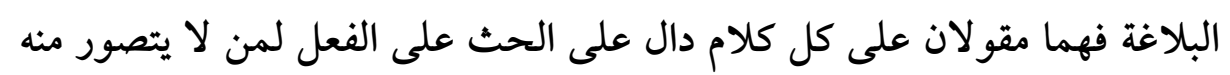

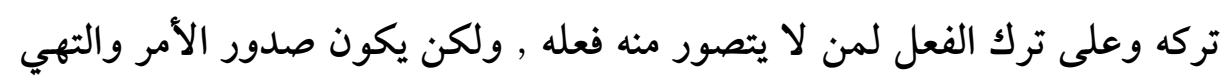

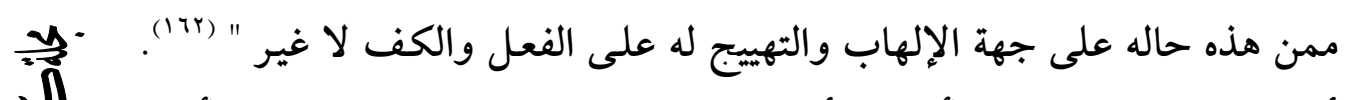

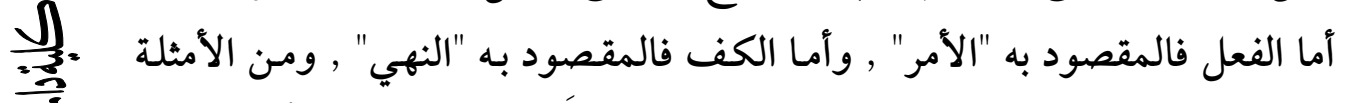

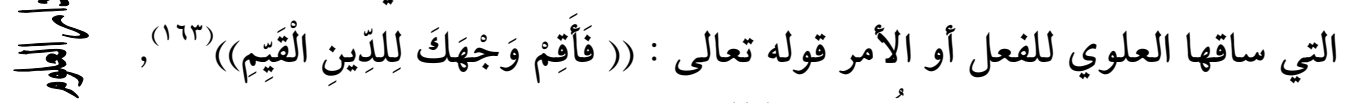

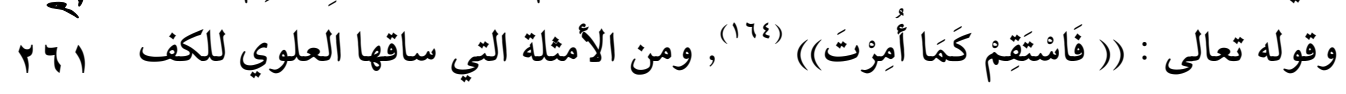

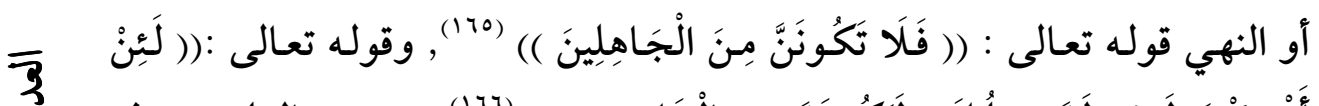

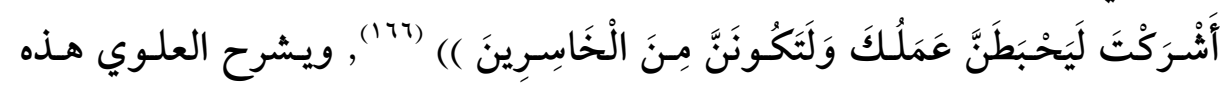

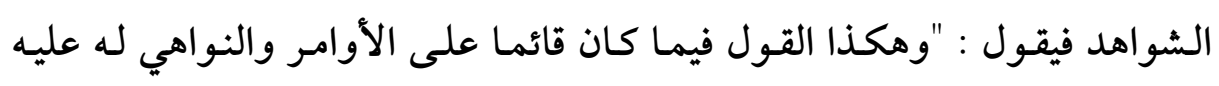

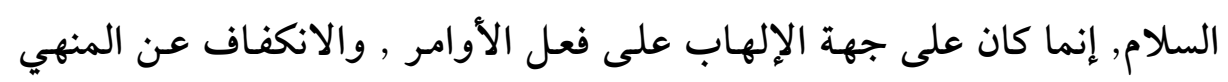

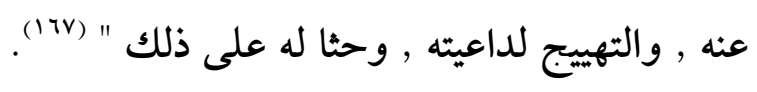

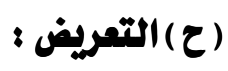

يصرح الزركشي بوضسوح الشبه بين التعريض والجـل لـ ومسن ثم فهو يسميه

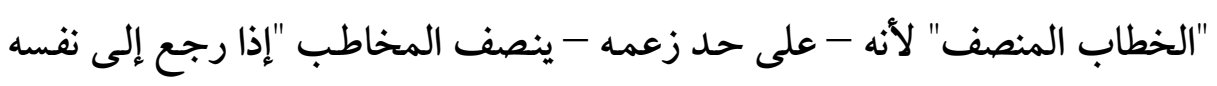

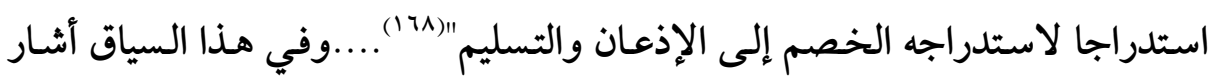
الزركشي إلى أن السكاكي وضع التعريض ضمن منظومة "المغالطات المعنوية" (199.). 
والتعريض وفق تعريف ابن حجة الحموي "هو عبارة عن أن يكنى المتكلم بشيء

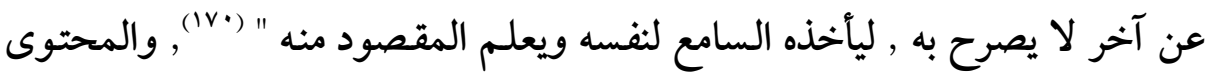

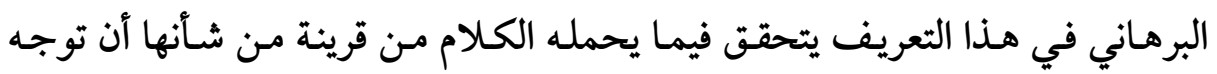

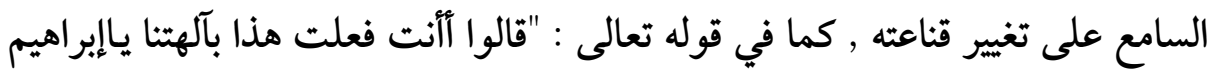

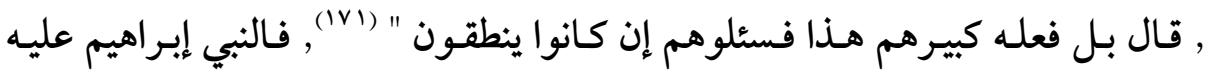

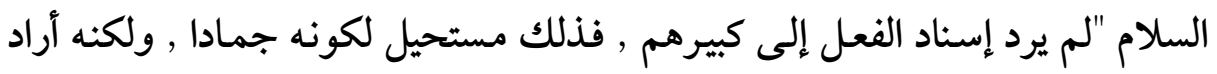

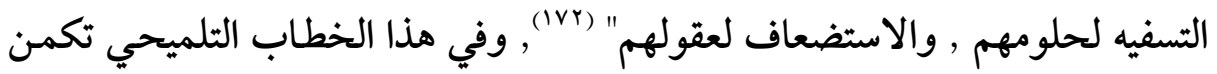

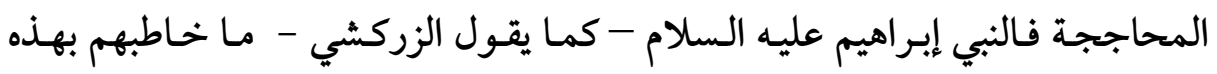

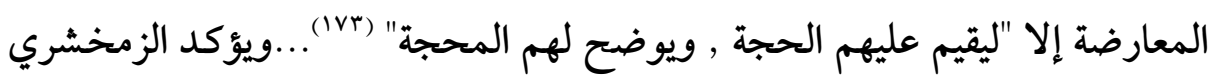

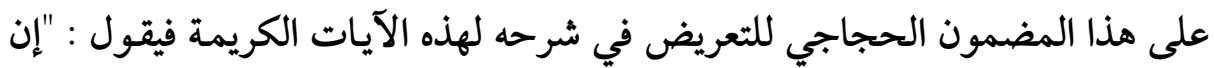

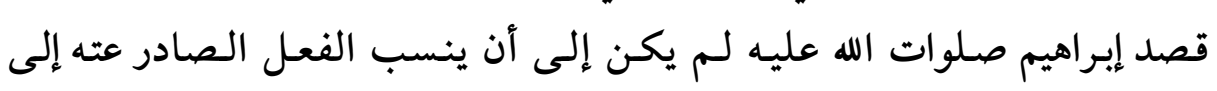

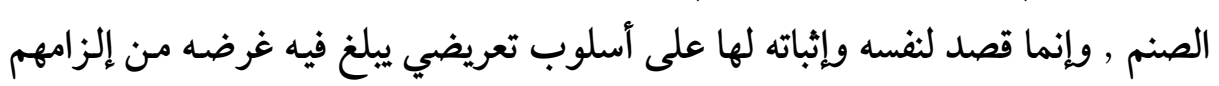

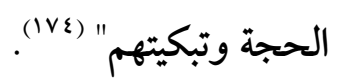
وقد يقترب مفهوم التعريض من مفهوم الكناية مما يفسر أن عددا كبيرا من البلاغيين rit

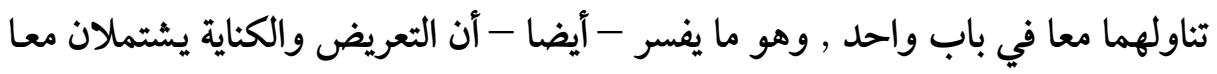

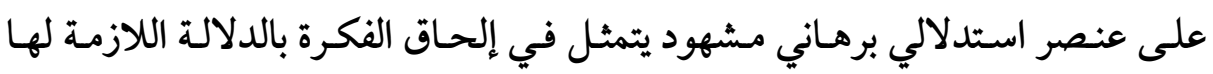
$\overline{3}$

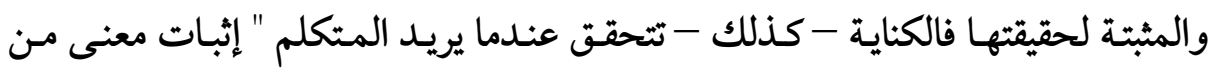

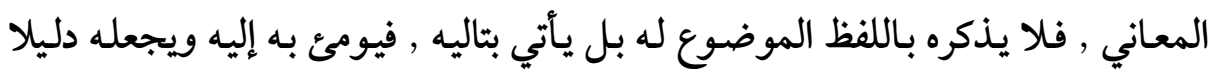

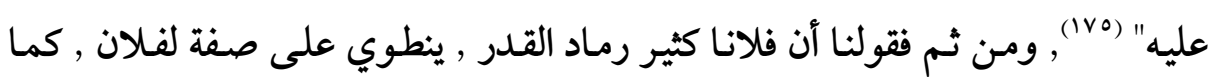

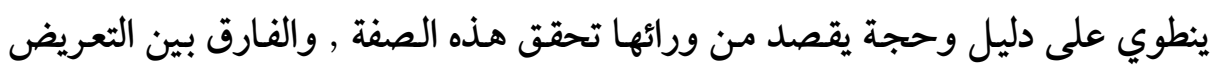

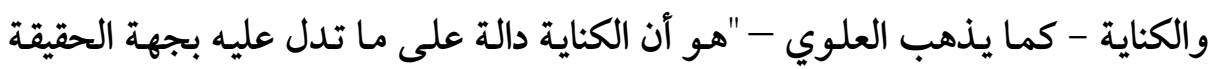

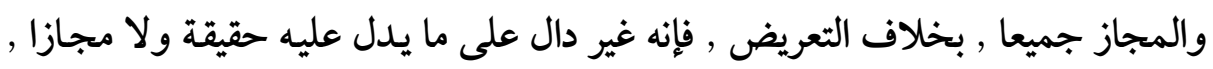

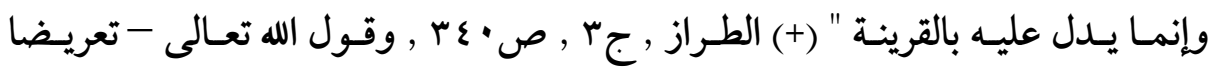

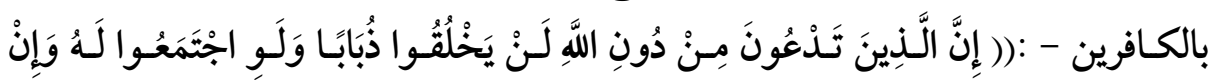




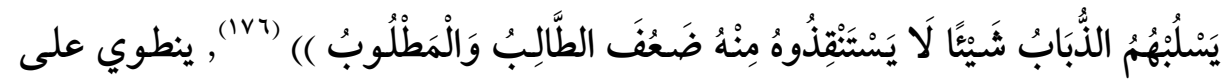
الدليل الذي يُستَّل به على ضعف معتقد الكافرين (ivv).

(ط) التسليم :

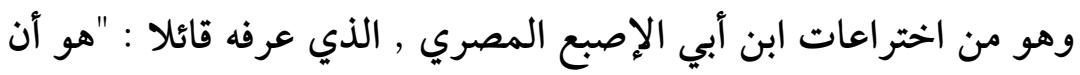

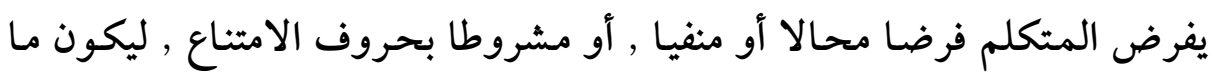
ذكره ممتنع الوقوع , لامتناع وقوع مشروطه , ثم يسلم بوقوع ذلك الك تسليما جدليا ,

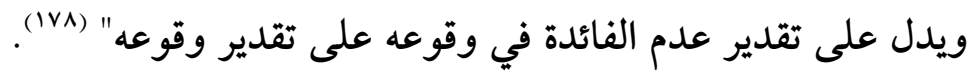

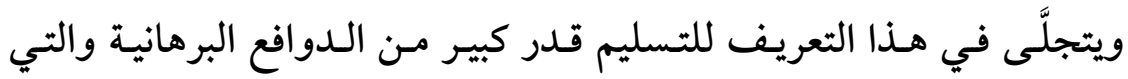

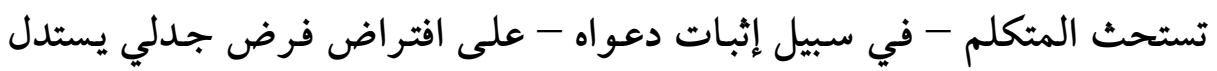

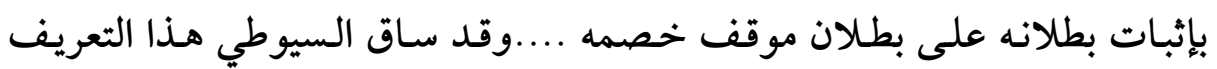

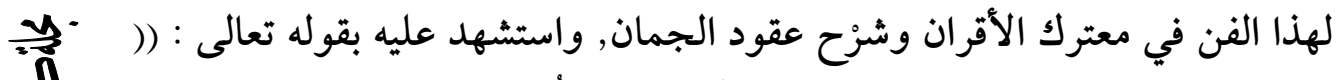

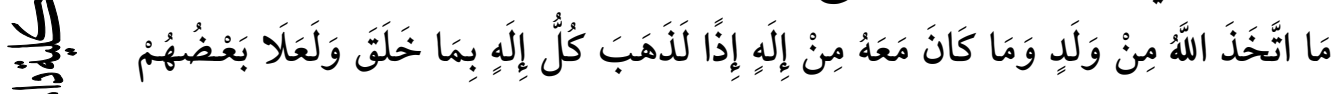

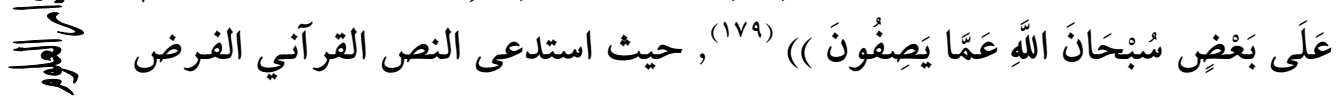

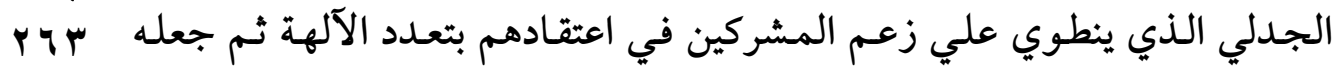

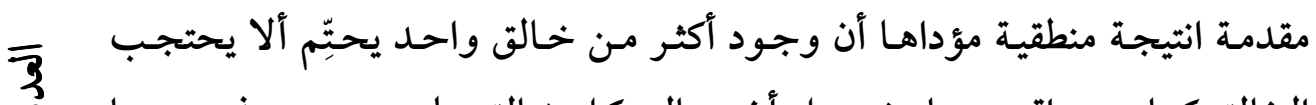

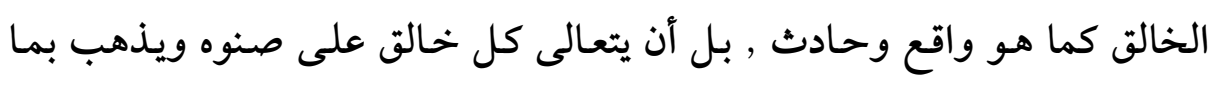

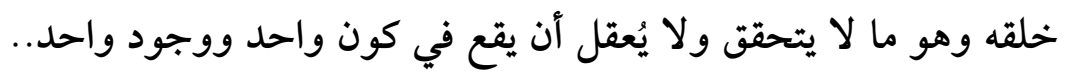

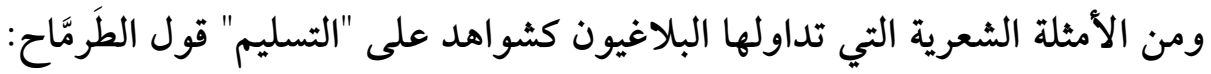

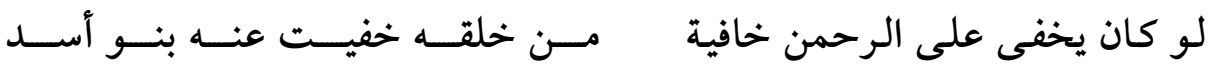
وقول الآخر : سألت في الحب عذالي فما نصحوا وهبـه كـان فمـا نفعي بنصحهم (•A"). 


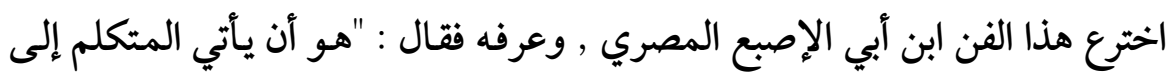

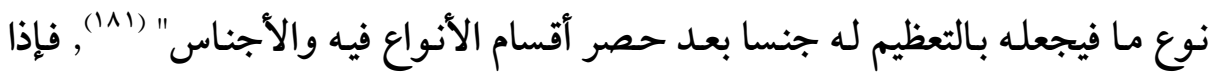

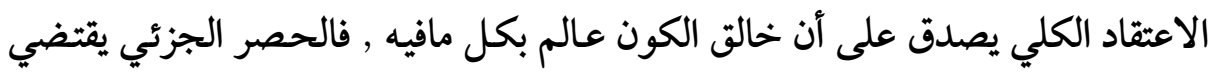

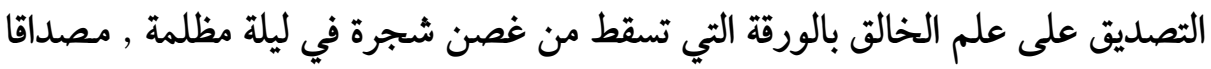

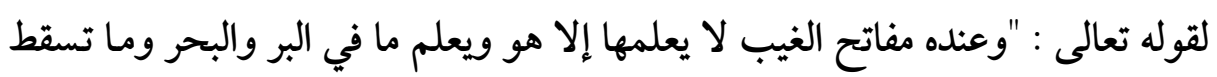

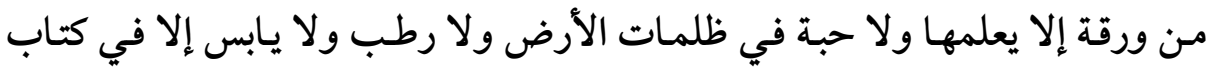

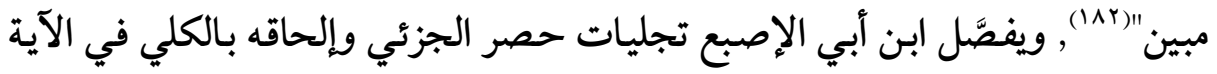

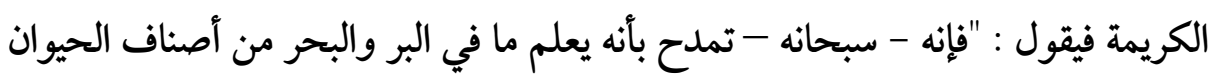

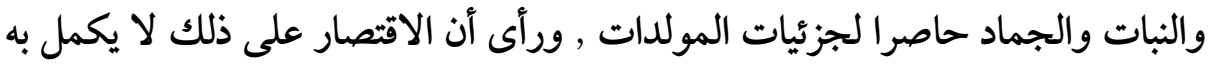

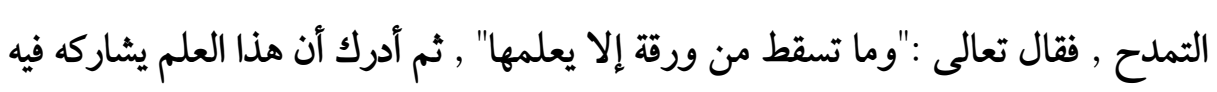

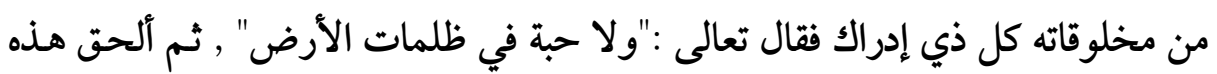

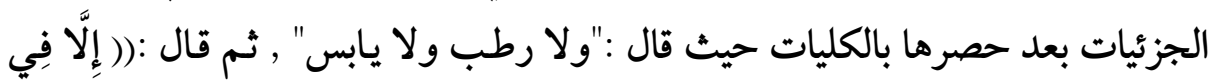

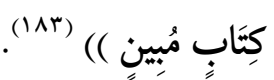

وقد نقل هذا الفن عن ابن أبي الإصبع المصري ابن حجة الحموي والسيوطي وابن

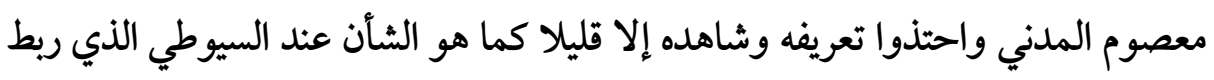

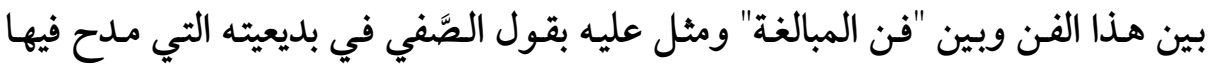

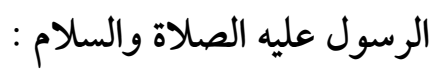

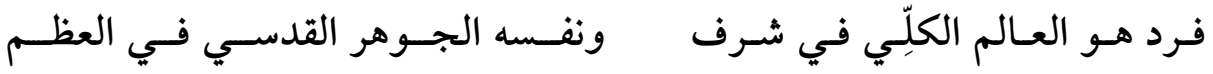

وقد أشار "بيرلمان" إلى حصر الجزئي وإلحاقه بالكلي في كتابه هذه الحجر argumentation

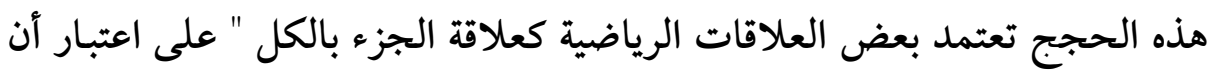

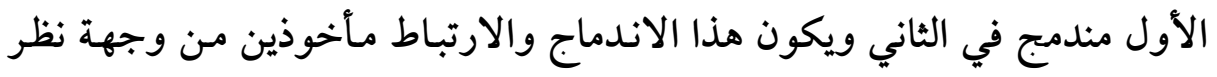


" ومـن هـذه الحجـج أيسضا تقسيم الكل إلى أجزائه المكونـة لـه كي يتسنى

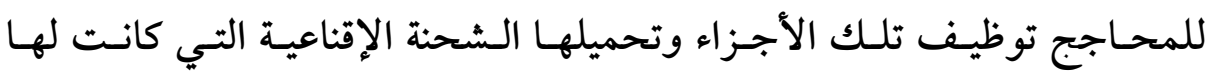

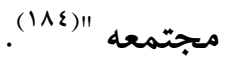

(ك) المناقضة :

عرَّفها ابن حجة الحموي فقال :"هي تعليق الشرط على نقيضين ممكن ومستحيل

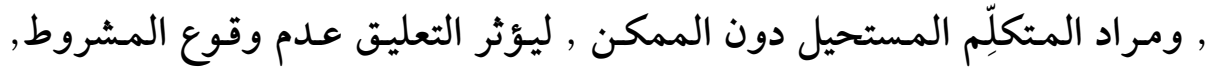

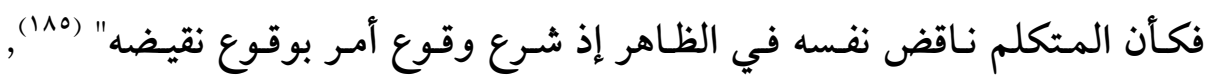
ومثالها قول النابغة :

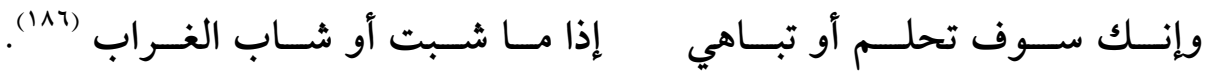

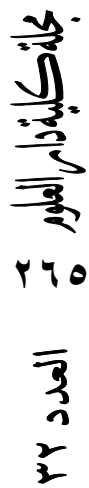

وإنسي سـوف أسـلوهم إذا عـدمت روحي وأحييت بعد المـوت والعدم (IAv . ومثله قول عبد الغني النابلسي في بديعيته :

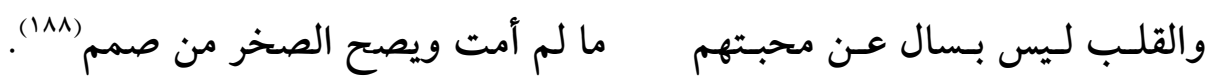

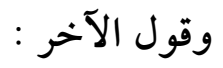
إنــي أنــاقض عهـــد النـازحين إذا ما شاب عزمي وشابت شهوة الهرم (1^9).

والتناقض يعد ركنا ذي أهمية بالغة في التنظير الحجاجي , وهو يمثل مجلى مهما من مجالي الحجج شبه المنطقية عند "بيرلمان" , حيث يتم توظيف التعارض

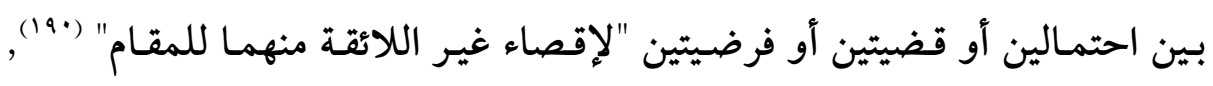
والتناقض المقصود عند "بيرلمان" قد يصنعه المحاجج (الباث) وقد يتحقق تلقائيا في موقف المخاطَب (المتلقي) , وفي كلتا الحـالين يسعي المحاجج "لإقصاء إحداهما لإقناع مخاطبيه بالأخرى " (191). 


\section{الخاتةة:}

قدمت الدراسة قراءة للمضامين الحجاجية في المصطلح البلاغي , تجتهد في نفض الغبار الذي علق بهذا المصطلح بعد اتهام البلاغة برمتها أنها علم نضج

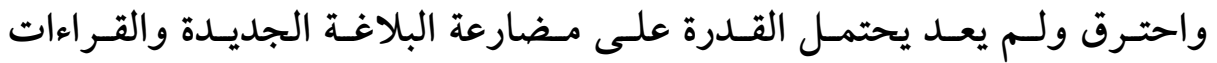
الأسلوبية المعاصرة , وبعد أن استفحل خطر اتجاه تغريبي ظل يجتهد في السعي إلى فرض مصطلحات وافدة على سياق الثقافة العربية رغبة في إثبات المعاصرة ومواكبة الجديد , وكان يمكن أن يمثل هذا الاتجاه التغريبي إضافة حقيقية للنظرية البلاغية العربية , لولا أنه لـم يتجاوز "وضع القبعة" على مضامين بلاغية عربية

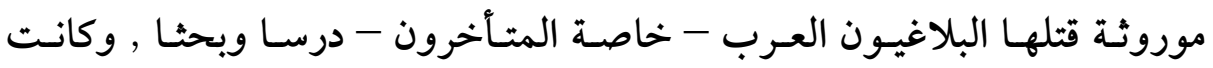
المحصلة في ذلك إهالة التراب على موروث جليل لطالما جفل من طول انزوائه

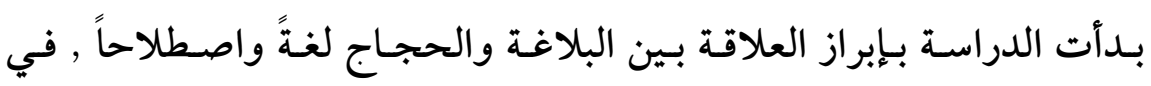
في مجاهل النسيان ل... المعالجـات الأوربيـة الحديثـة لمفهـوم الحجـاج , والدراسـات العربيـة القديمـة لمفاهيم البلاغة , وهو ما طرح حقيقة علمية مؤداها أن البلاغة العربية كانت تتسع หฯ في احتواء المضامين الحجاجية كلما مر الزمن , وهو ما تجلَّى في الموازنة بين المحتوى الحجـاجي والخطـابي في مـصنفات البلاغيـين المتقـدمين ونظيـره في مصنفات البلاغيين المتأخرين .... وفي سبيل تحديد مستوى المضامين الحجاجية في المصطلح البلاغي العربي, وزعت الدراسة المصطلحات البلاغية على قائمتين : إحداهما : قائمة المصطلحات البلاغية التي احتملت مضامين بلاغية راسخة من خلال المعالجات المختلفة للبلاغيين .. وتشمل هذه القائمة : -(أ): المصطلحات المجازية (التشبيه - الاستعارة - الكناية - المجاز المرسل

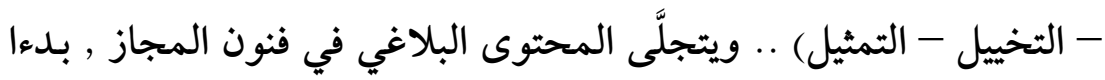

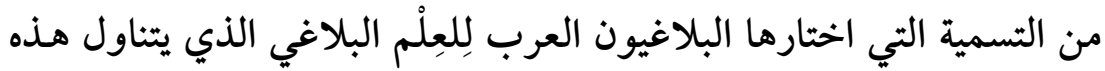


الفنون المجازية , ألا وهـو "علم البيـان" , بمـا ينطوي عليه مـن مفـاهيم

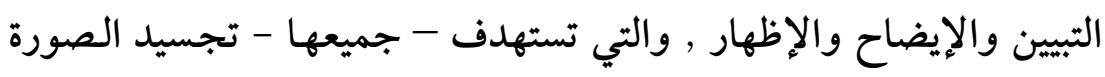
في ذهن المتلقي ل...

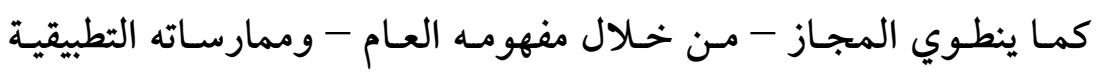

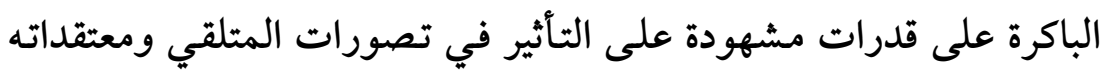

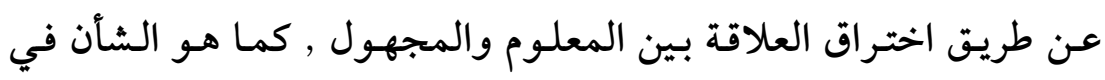

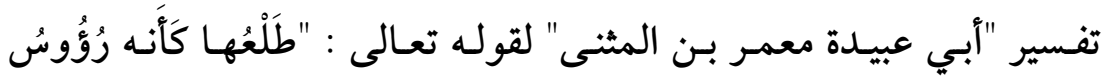

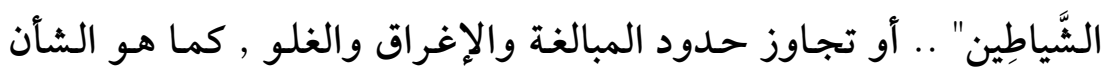
في معالجات قدامة بن جعفر لهذه القضايا , أو الإفراط في استخدام مبدأ

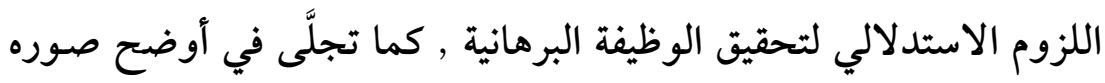

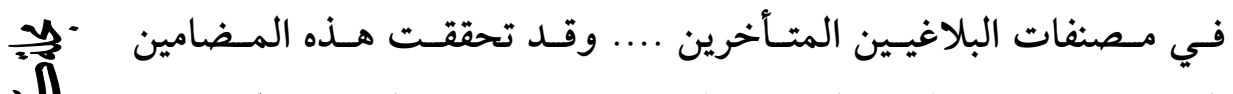

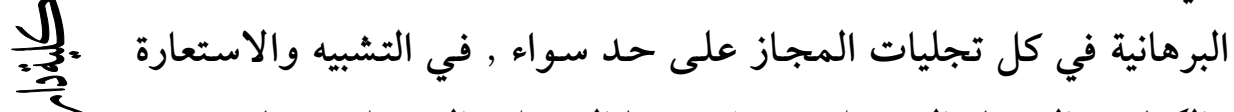

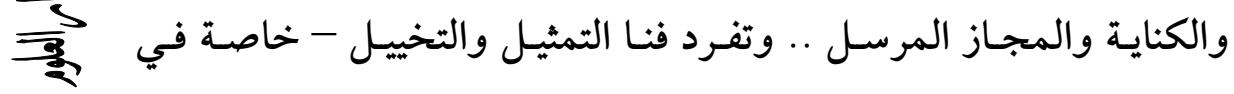

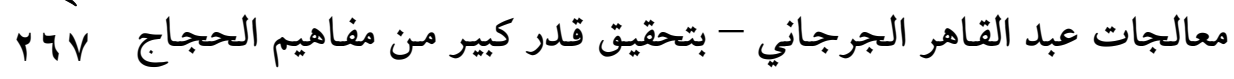

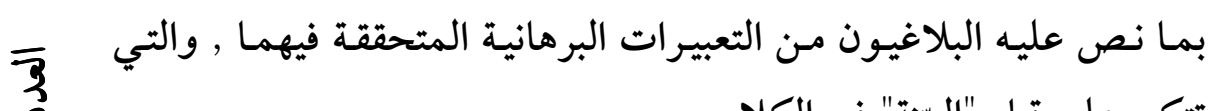
تتكئ على قيام "البيّنة" في الكلام ..

2

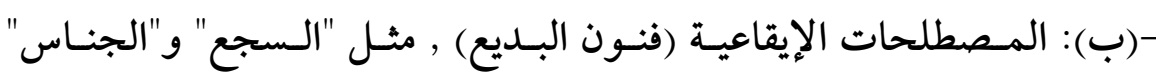
و"الترصيع" و"التسميط" و"التصدير" و"الطباق" و "المقابلة" و "التكرار" . . .

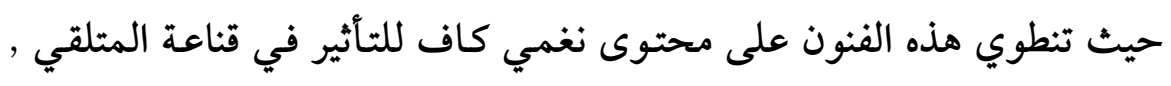

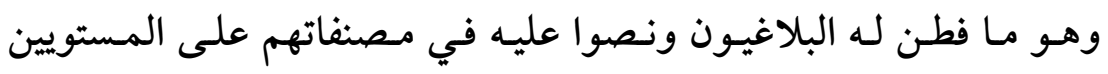

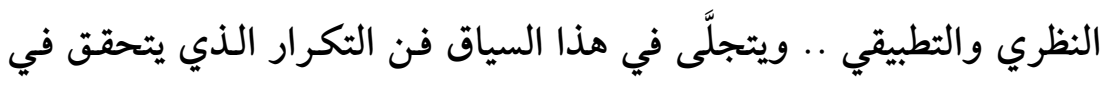

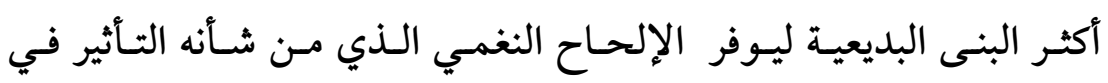

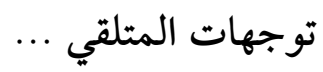
-(ج): مصطلحات علم المعني (الاستفهام نموذجا) : 
حيث أشـارت الدراسة إلى ما يقوم بـه أسلوب الاستفهام في الدراسات

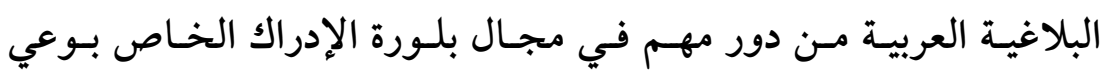

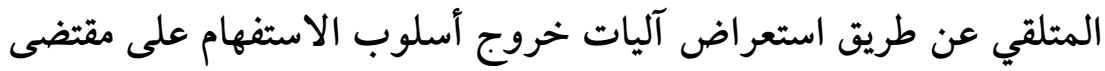

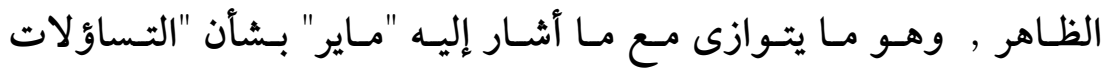

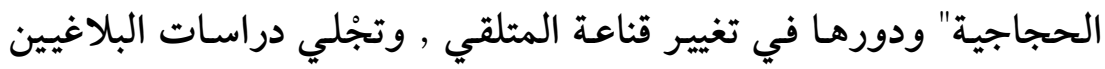

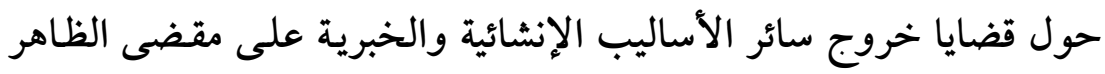

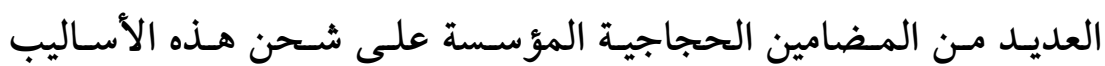
بقدرات هائلة على حمل تأثيرات خطابية مشهودة تتحقق من خلال تجاوز

$$
\text { ظاهر الوضع اللغوي ... }
$$

والقائمـة الأخـرى : قائمسة المصططلحات البلاغية ذات المنطلق الحجـاجي ,

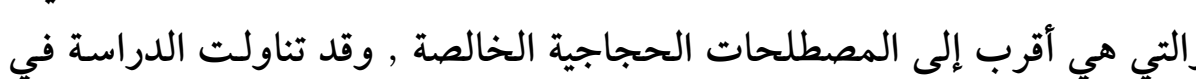

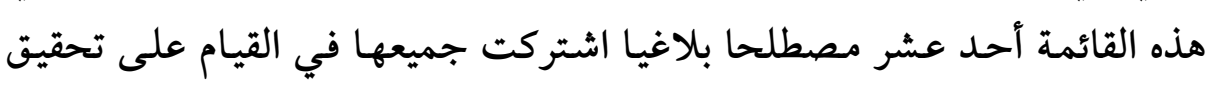

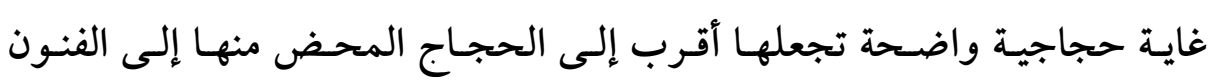

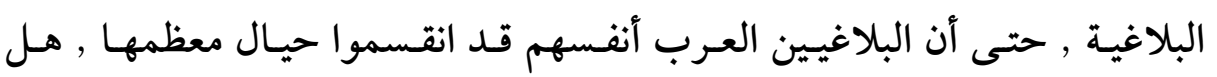

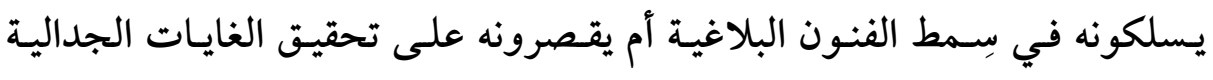

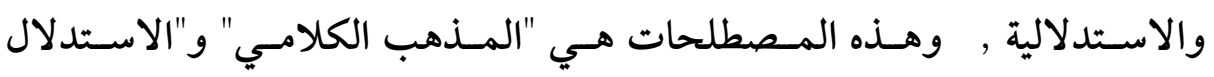

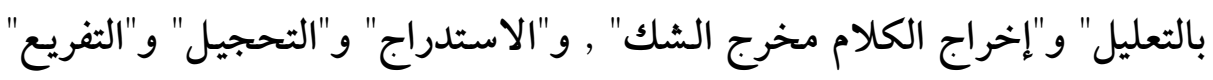

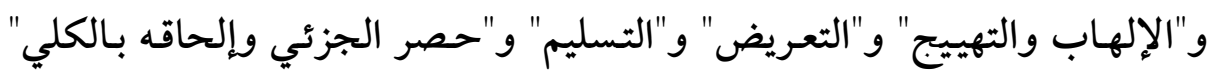

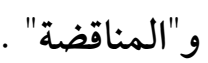

وأشارت الدراسة إلى نقاط التماس الواضحة بين المحتوى الحجاجي في كثير

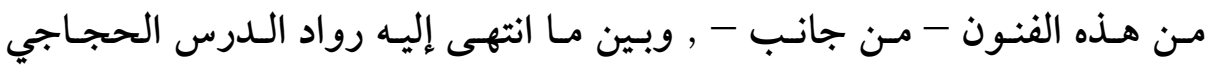

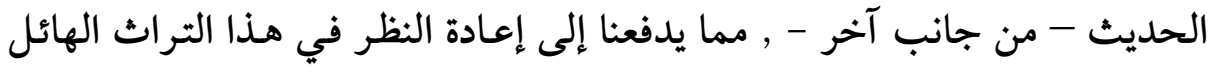

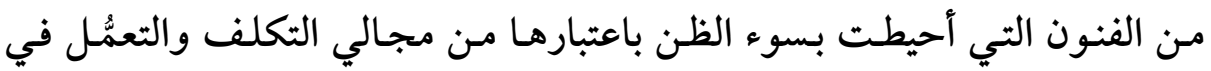
غضون مرحلة الفراغ الحضاري .. 


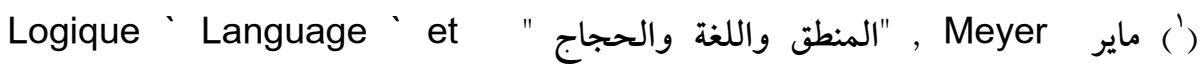
argumentation

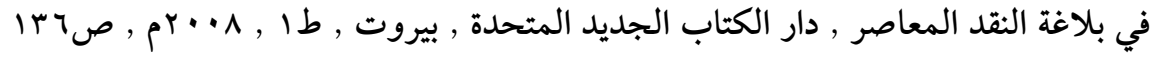

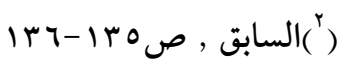

(r) ابن منظور , لسان العرب , طبعة مراجعة ومصححة بمعرفة نخبة من السادة الأساتذة

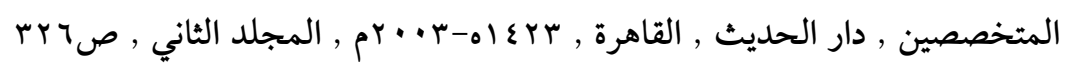

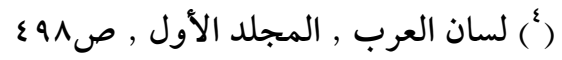

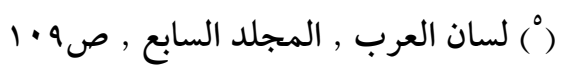

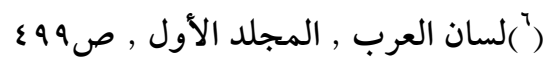

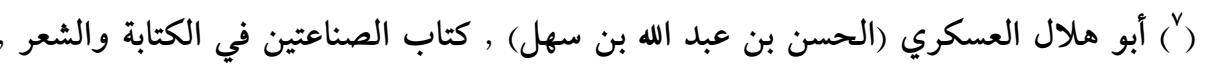

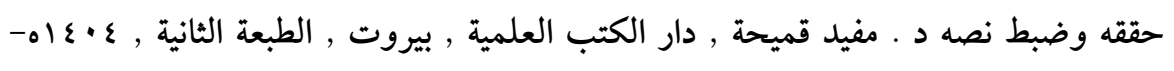

$$
\text { Q }
$$

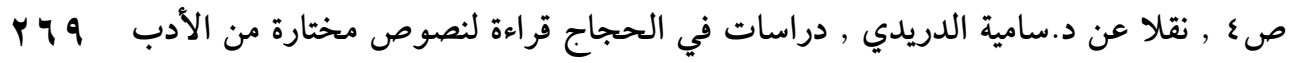

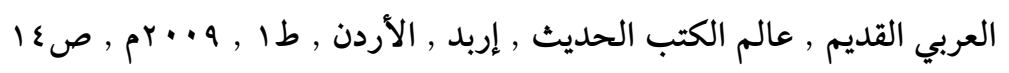

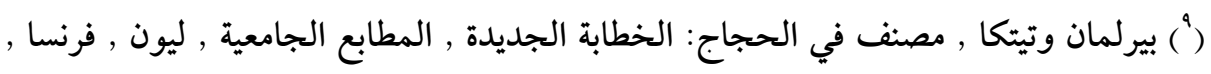

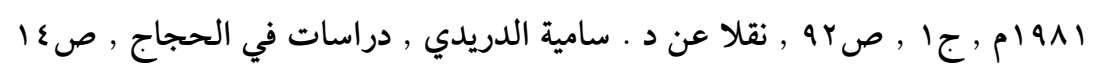

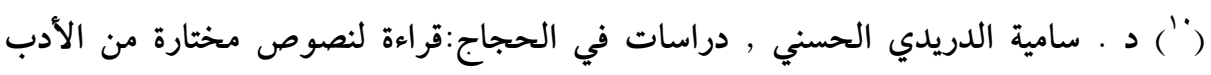

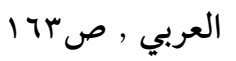

(") السكاكي (أبو يعقوب محمد بن علي بن محمد) , مفتاح العلوم , طبعه ونشره نعيم زرزور

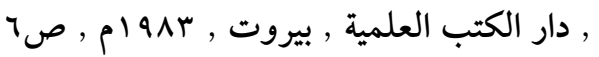

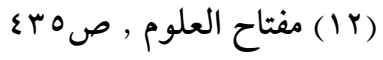

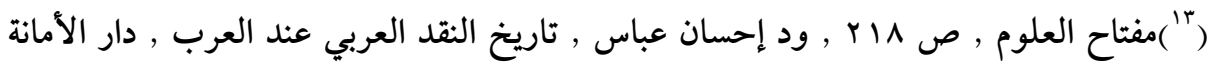

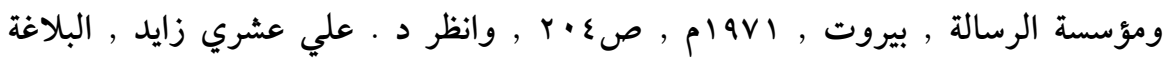

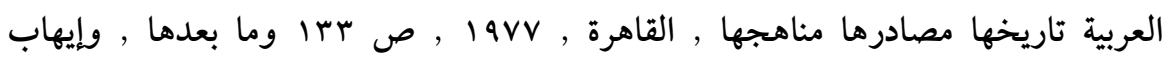
المقراني , أثر المنهج البلاغي للسكاكي وتلامذته في اتجاهات الإبداع الشعري من القرن إناهن 
السابع حتى مطلع القرن العاشر الهجري , رسالة ماجستير مخطوطة , كلية دار العلوم ,

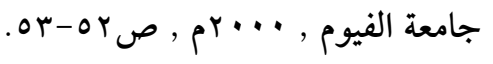

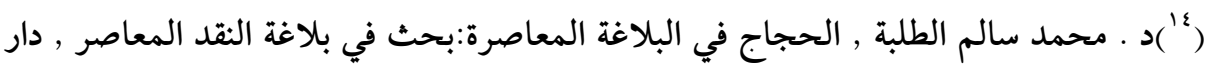

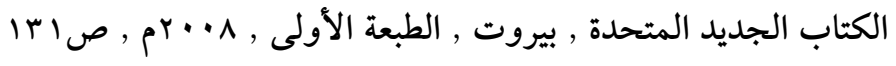

(10)

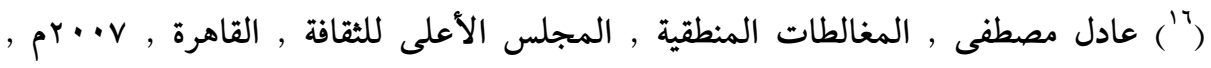

$$
\text { ص }
$$

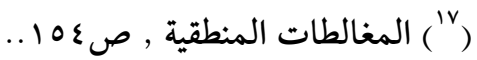

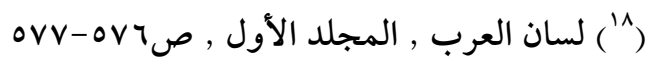

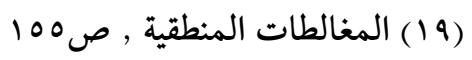

70

(") أبو عبيدة معمر بن المثنى , مجاز القرآن , تحقيق د محمد فؤاد سزكين , الطبعة الثانية ,

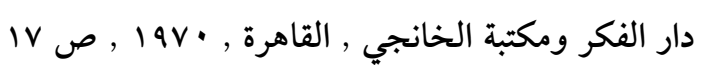

Ir)

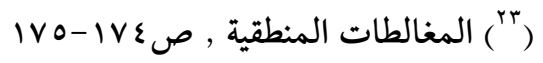

rV.

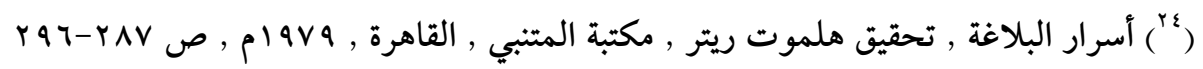

rio

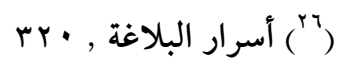

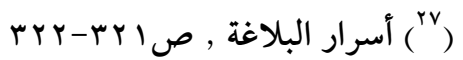

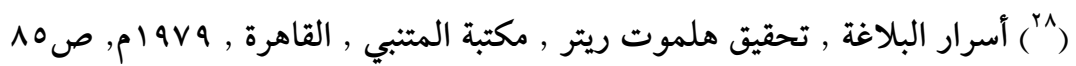

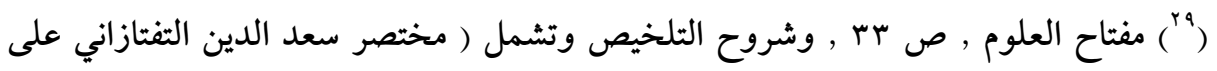

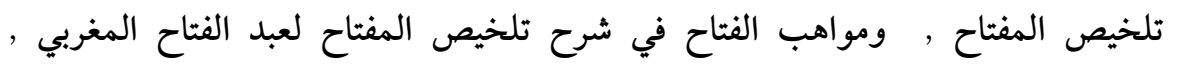

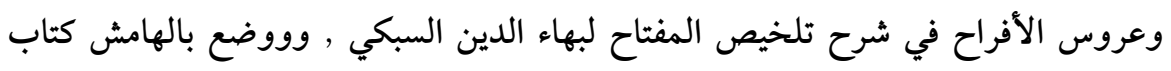

الإيضاح لمؤلف التلخيص جلال الدين القزويني , وحاشية الدسوقي على شرح السعد الدئ ) ,

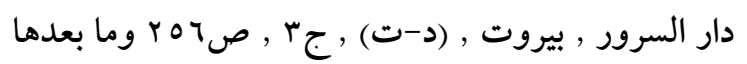

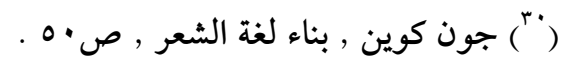


(") المرزباني (أبو علي أحمد بن محمد بن الحسن المرزوقي) , الموشح في مآخذ العلماء

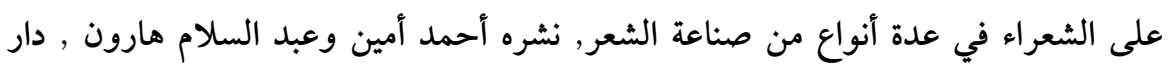

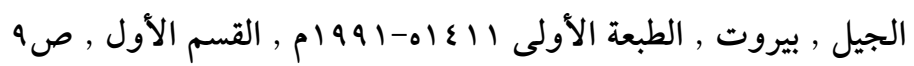

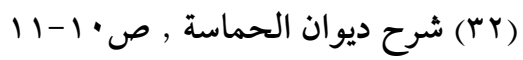

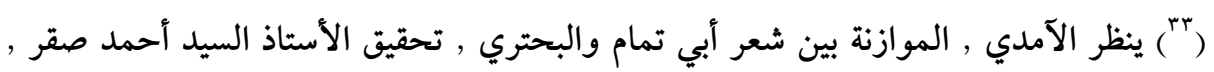

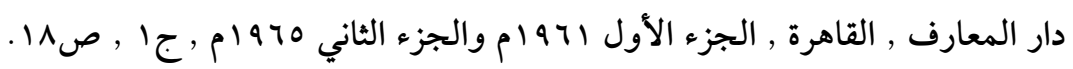

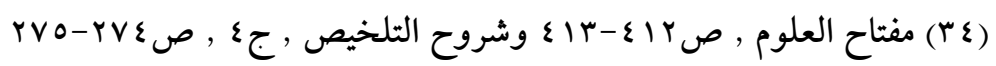

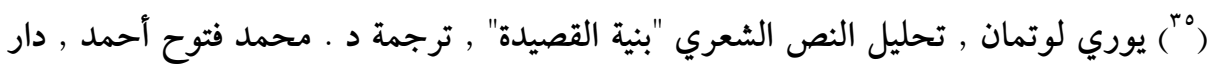

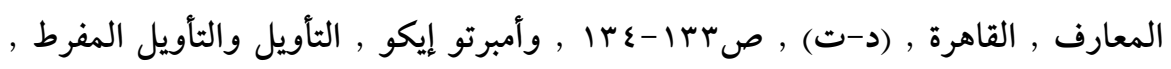

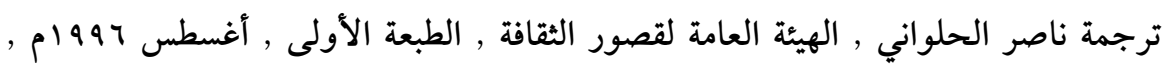

$\left(^{r v}\right.$ Sylvan Barnet(and athers): Dictionary of literary terms .

CanstableLondon , וqv , p Ir......

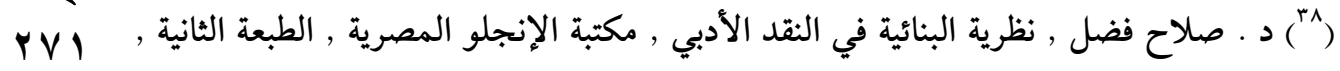

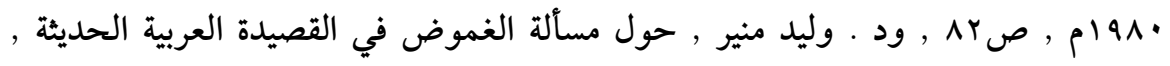

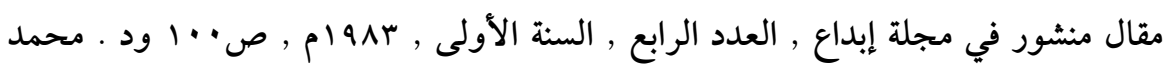

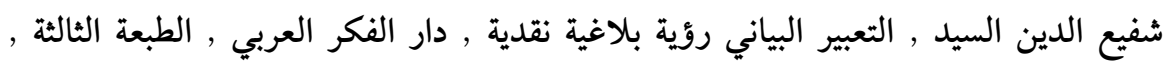

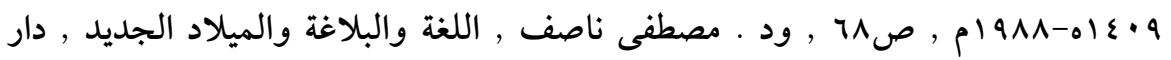

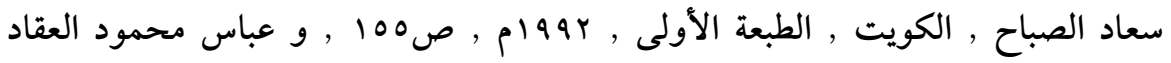

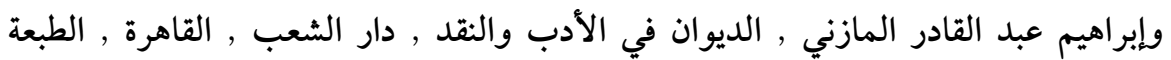

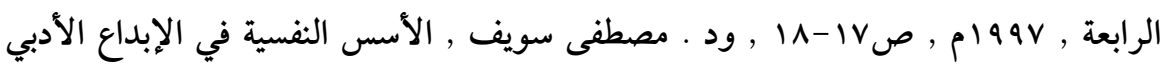

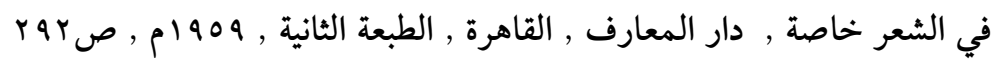

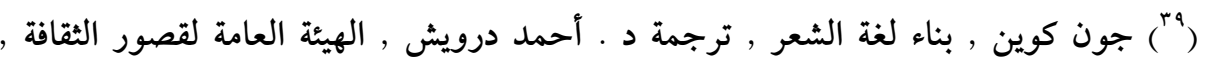

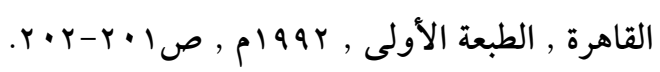

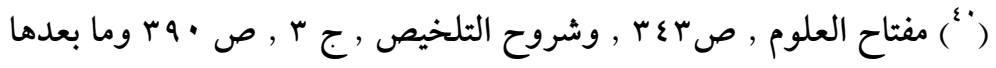

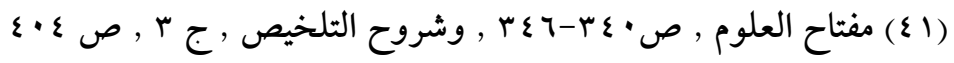


(r) يحي بن حمزة العلوي , الطراز المتضمن لأسرار البلاغة وعلوم حقائق الإعجاز , تقديم

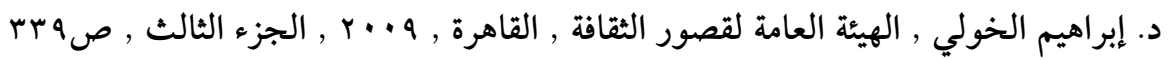

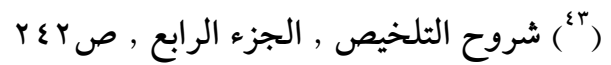

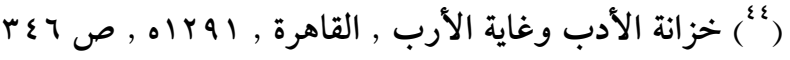
r

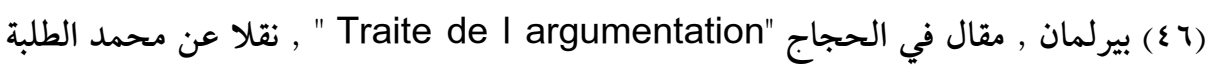

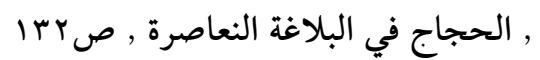

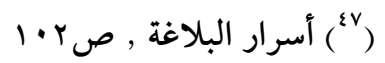

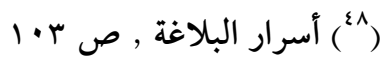

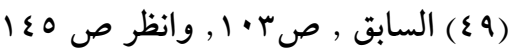
(") (1) ( )

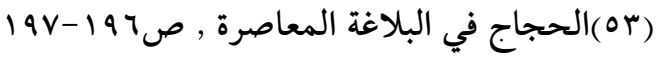

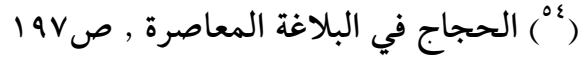
YVY

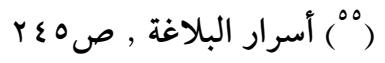
r

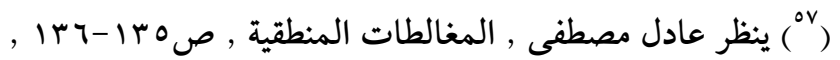

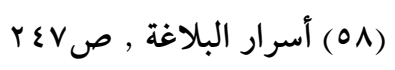
(")

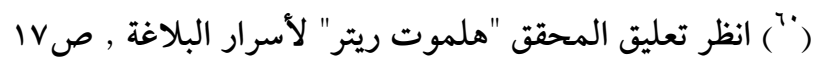

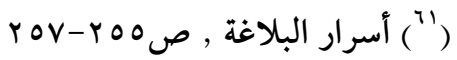

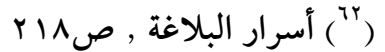

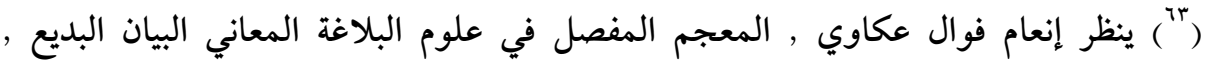

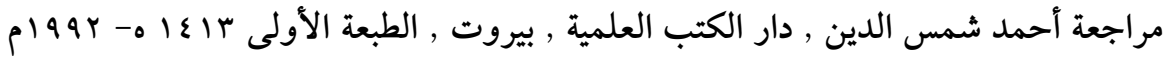
صYTITIT, (") بديع القر آن , تحقيق د.حفني محمد شرف , لجنة إحياء التراث , (د-ت) , صזrا ا.... 


$$
\begin{aligned}
& \text { ( ) }
\end{aligned}
$$

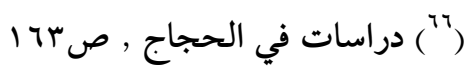

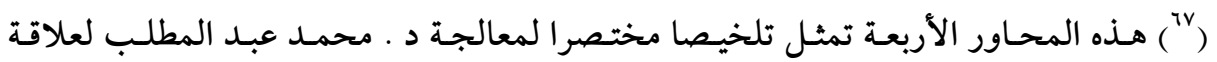

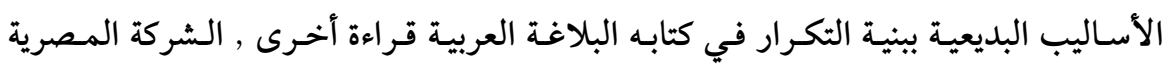

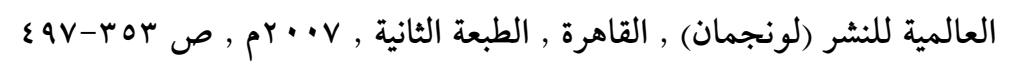

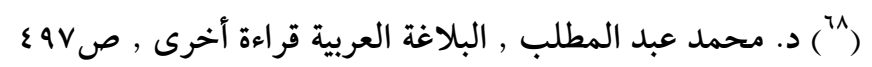

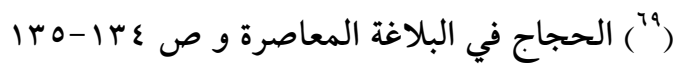

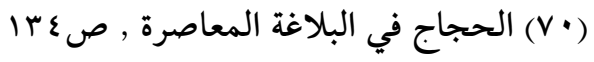

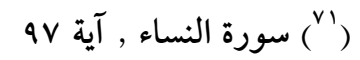

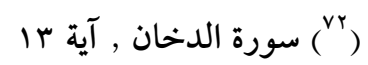

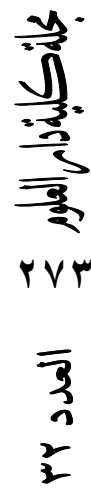

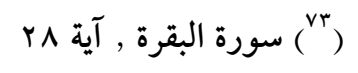

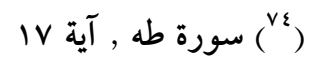

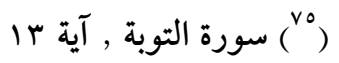$$
\text { r }
$$

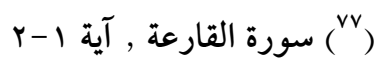

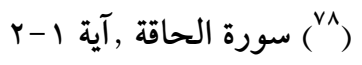

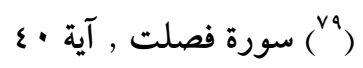

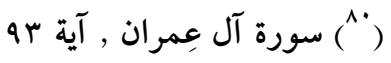

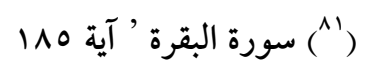

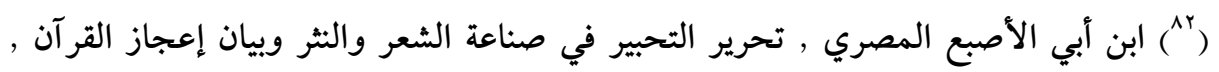

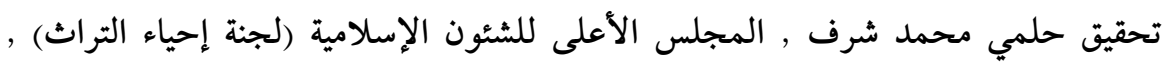

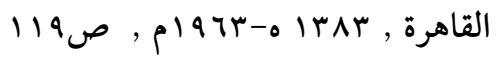

$$
\begin{aligned}
& \text { ( ) (السابق , نفسه }
\end{aligned}
$$

(ع) جلال الدين السيوطي , شرح عقود الجمان في علمي المعاني والبيان , حققه وعلق عليه

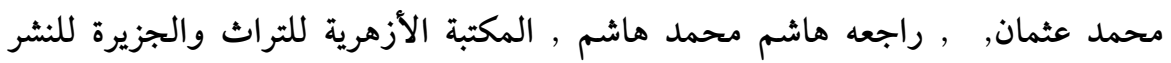

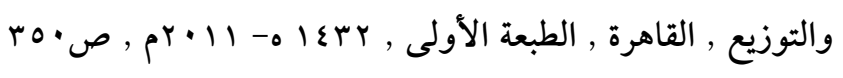

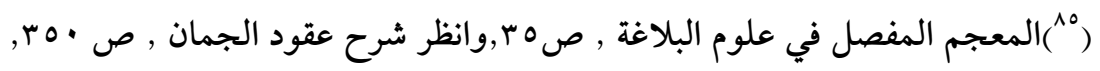


(^) عبد الله بن المعتز , كتاب البديع , اعتنى بنشره وتحقيق المقدمة والفهارس إغناطيوس

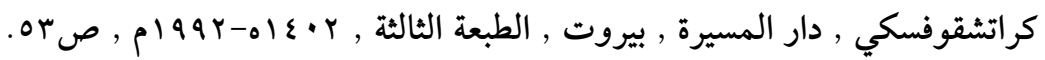

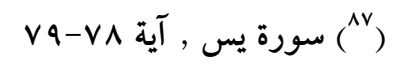

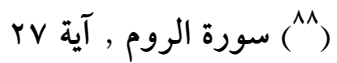

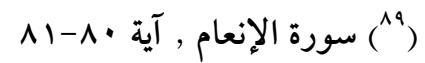

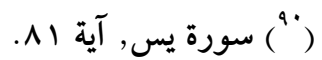

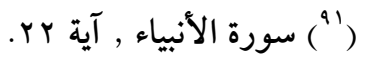

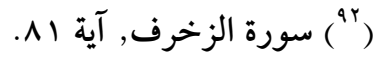

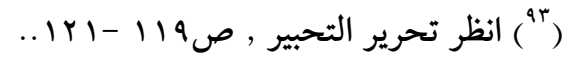

( (") وهو ما سيتبين في تناول الدسوقي في حاشيته على شرح السعد في الصفحات التالية

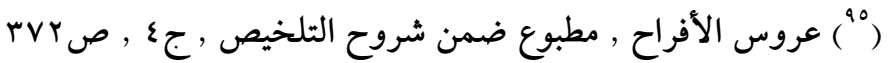

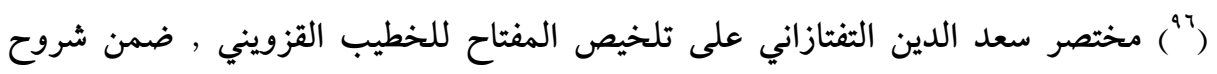

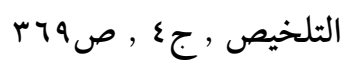

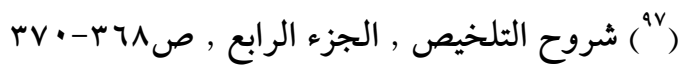

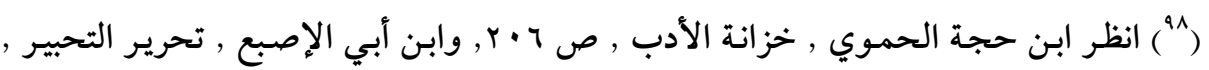

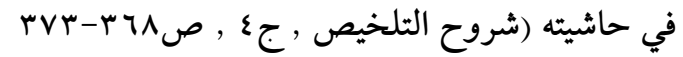

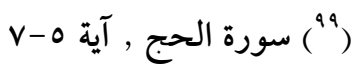

$$
\begin{aligned}
& \text { 119.' (') }
\end{aligned}
$$

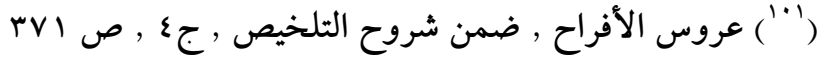

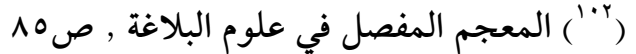

$$
\begin{aligned}
& \text { r.r. }
\end{aligned}
$$

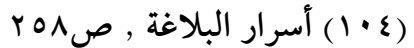

$$
\begin{aligned}
& \text { (0) (1 أسرار البلاغة , ص rVY }
\end{aligned}
$$

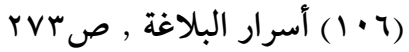




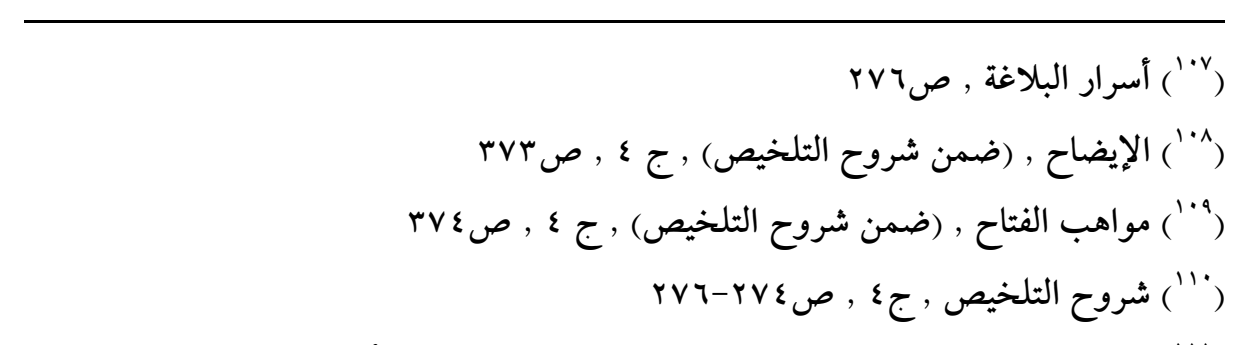

(') يحي بن حمزة بن علي العلوي اليمني , الطراز المتضمن لأسرار البلاغة وعلوم حقائق

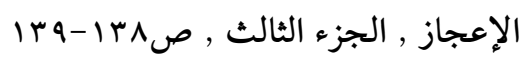

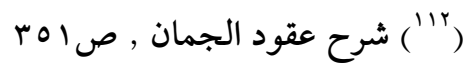

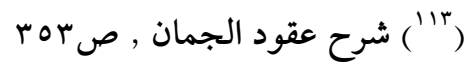

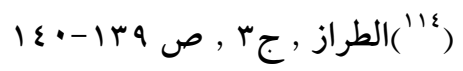

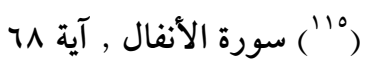

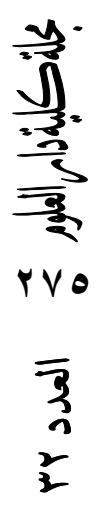

("7") ابن مالك (بدر الدين محمد بن محمد بن عبدالله) , المصباح في المعاني والبيان , حققه

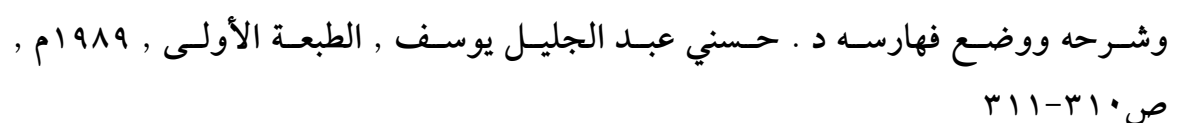

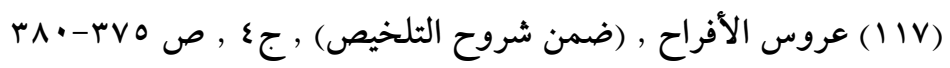

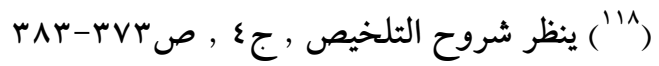

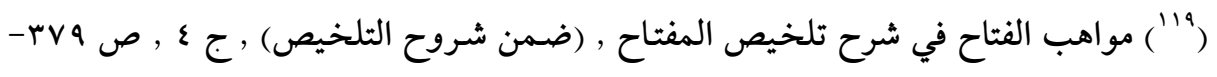

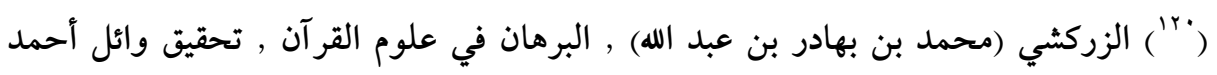

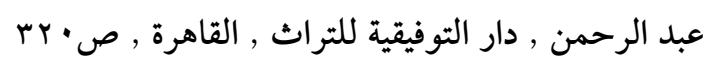

r ع (r)

N

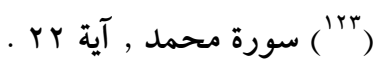

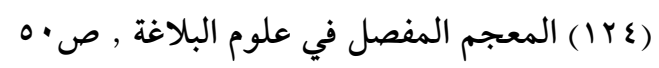

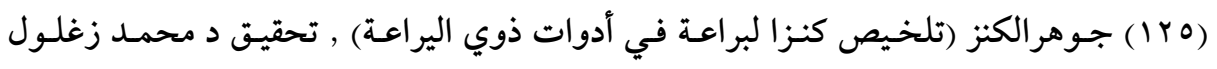

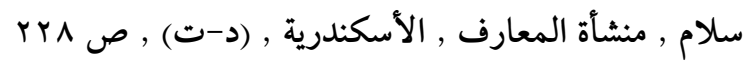

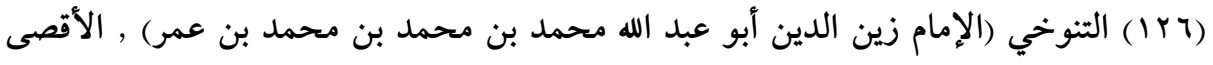

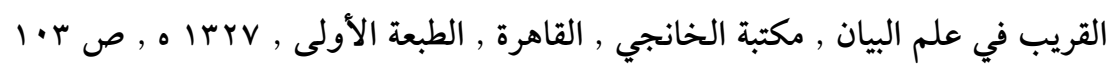


(IrV)

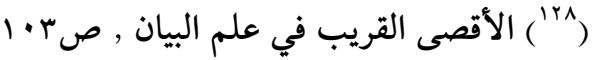

$$
\begin{aligned}
& \text { ( ) }
\end{aligned}
$$

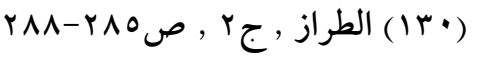

("r') ضياء الدين بن الأثير , المثل السائر في أدب الكاتب والشاعر , قدمه وعلق عليه د. أحمد

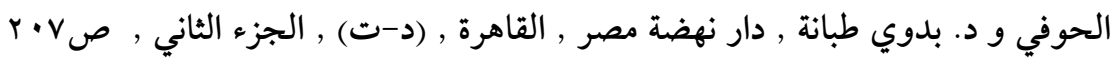

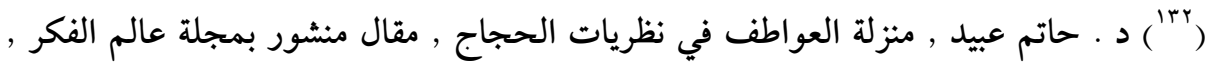

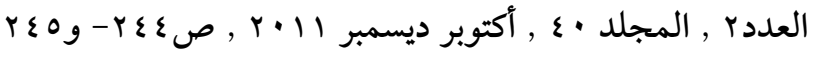

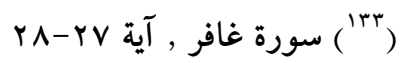

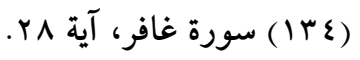

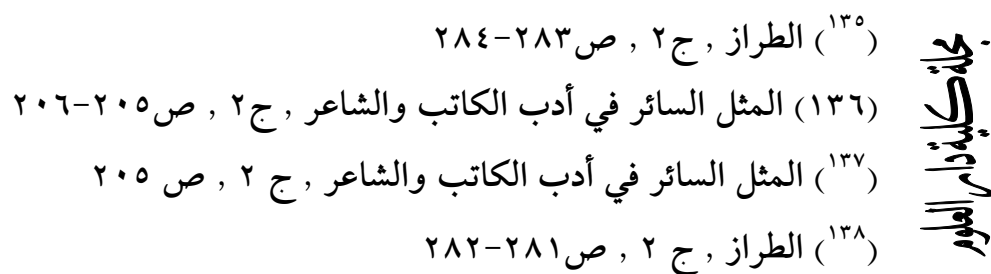

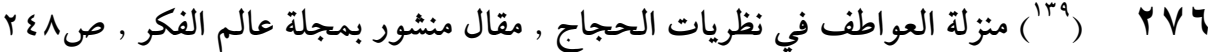

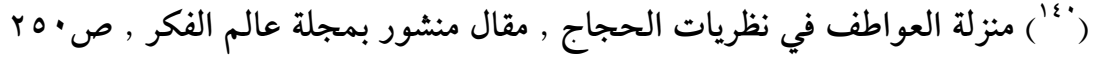

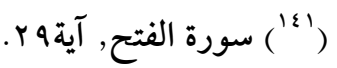

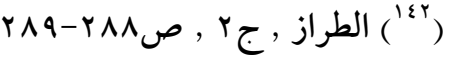

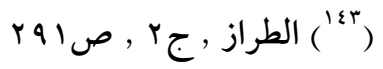

$$
\begin{aligned}
& \text { ( ) ( }
\end{aligned}
$$

(") حازم القرطاجني (أبو الحسن) , منهاج البلغاء وسراج أدباء , تقديم وتحقيق محمد

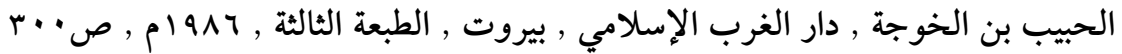

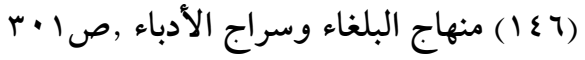

$$
\begin{aligned}
& \text { ( }
\end{aligned}
$$

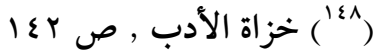

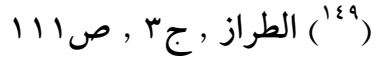




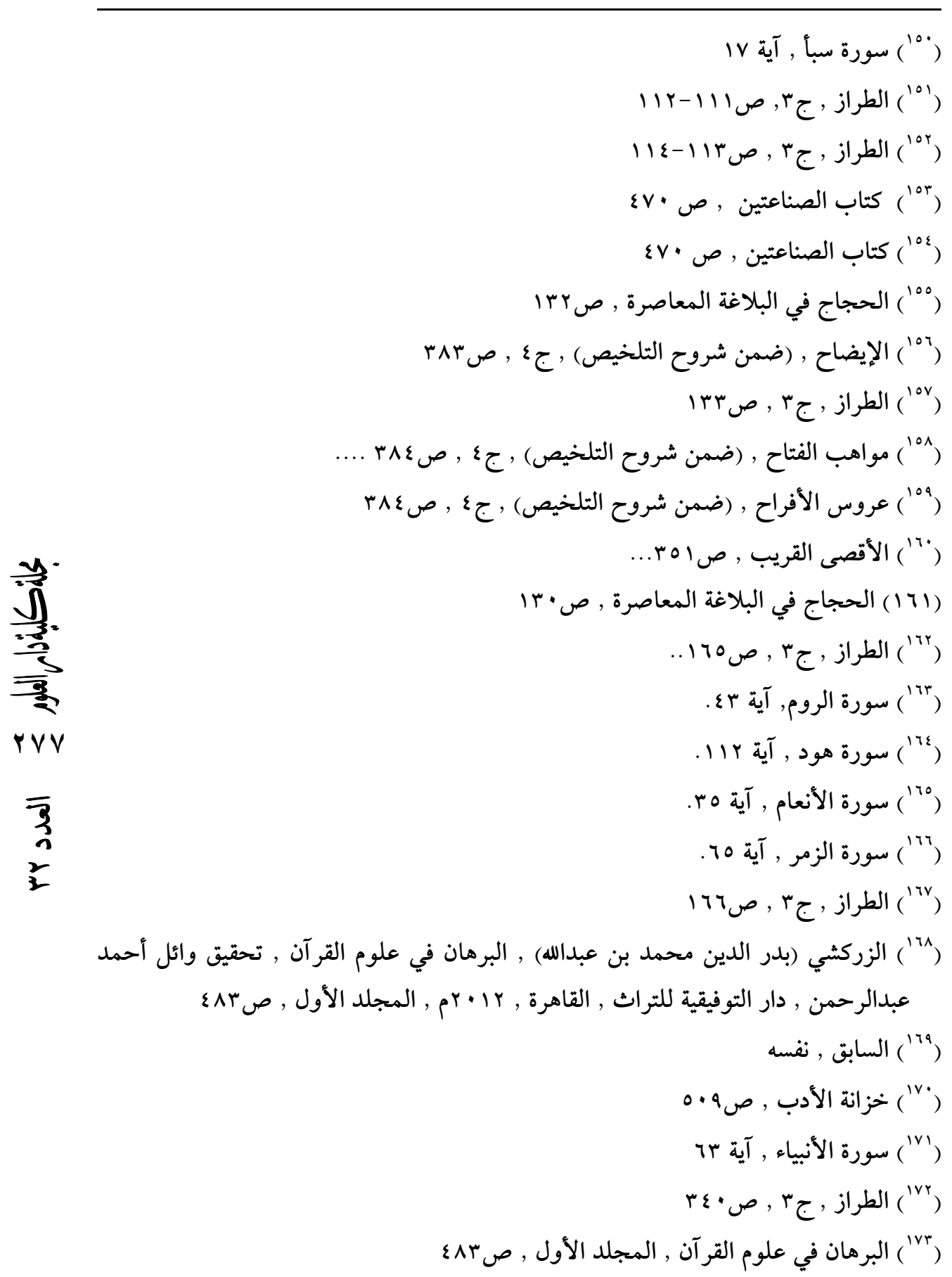


( (1) الكشاف عن حقائق التنزيل وعيون الأقاويل في وجوه التأيل , دار المعرفة , بيروت , د-

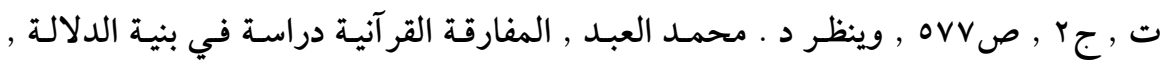

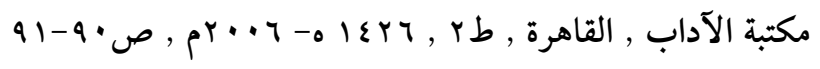

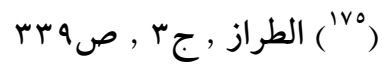
( )

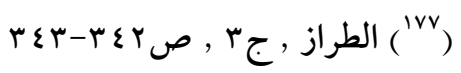
. 9) (1^)

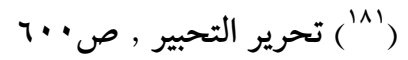

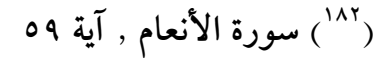

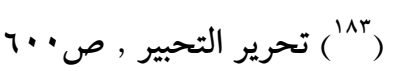

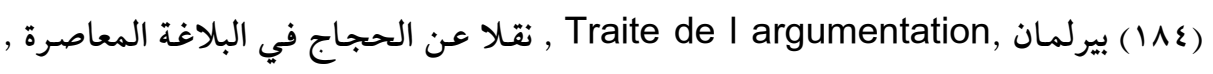
صو

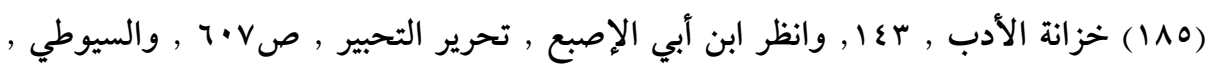

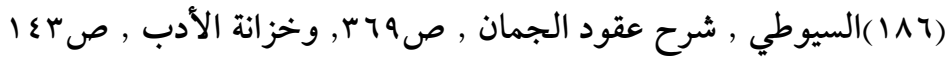

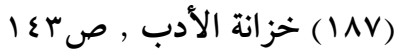

(1/A) النابلسي (عبد الغني بن إسماعيل) نفحات الأزهار على نسمات الأسحار في مدح النبي

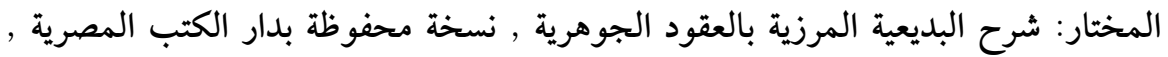

$$
\begin{aligned}
& \text { طبعة حجر, rra ام , ص ال }
\end{aligned}
$$

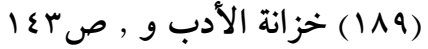

(") Traite de I argumentation , نقلا عن الحجاج في البلاغة المعاصرة ,

$$
\text { (191/191/السابق , نفسه . }
$$


المصادروالمراجع :

أولا : المراجع العربية :

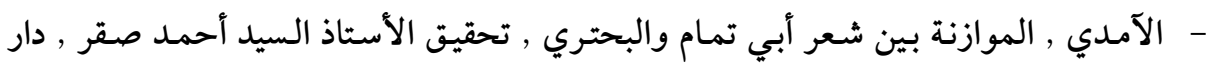

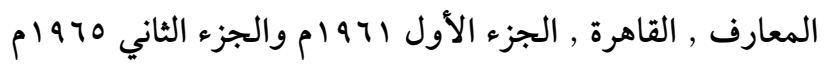

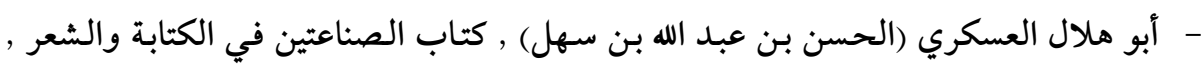

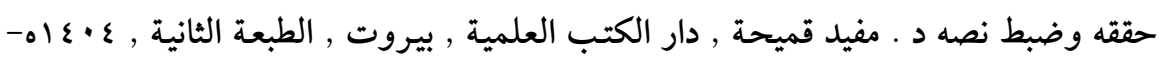
. - أبو عبيدة معمر بن المثنى , مجاز القر آن , تحقيق د محمد فؤاد سزكين , الطبعة الثانية , دار

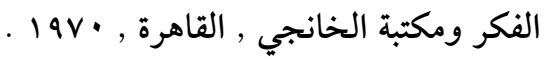
- ابن أبي الأصبع المصري , تحرير التحبير في صناعة الشعر والثثر وييان إعجاز القرآن ,

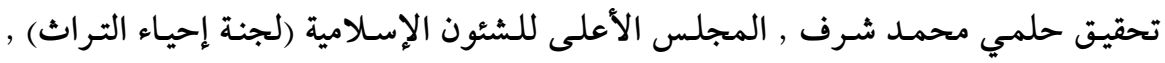

- ابن الأثير (نجم الدين) , جوهرالكنز (تلخيص كنزا لبراعة في أدوات ذوي اليراعة) , تحقيق

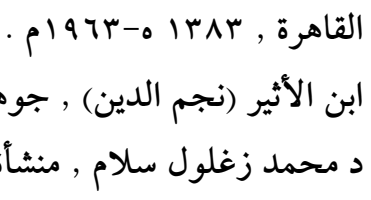

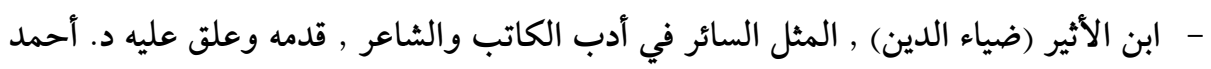

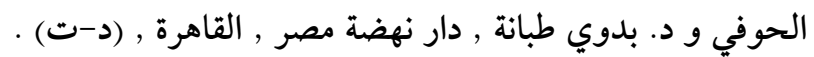

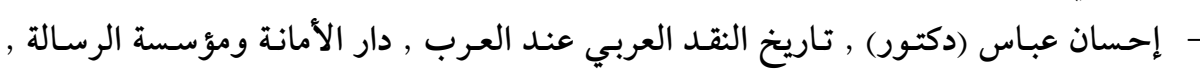

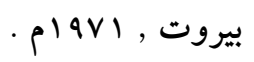

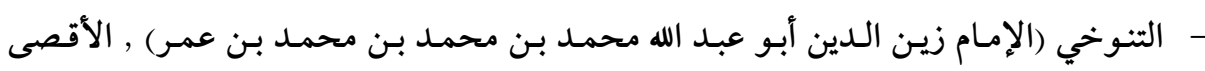

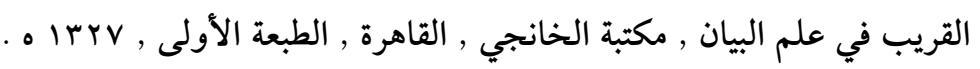

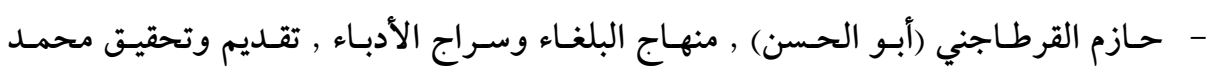

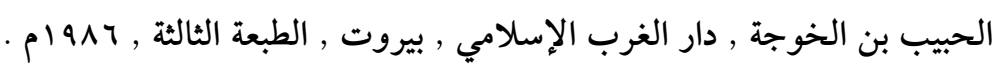

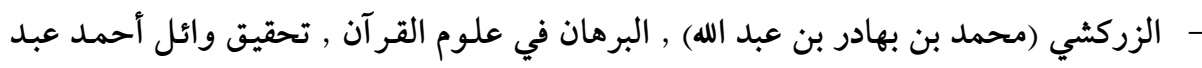

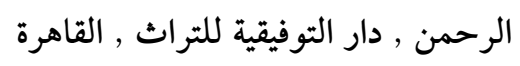
- الزمخشري (جار الله محمود بن عمر) , الكشاف عن حقائق التنزيل وعيون الأقاويل في

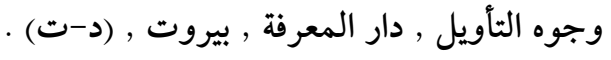

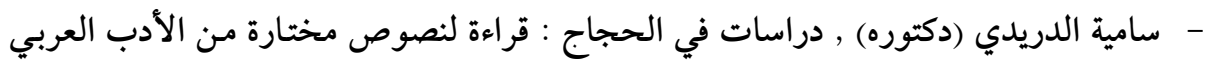

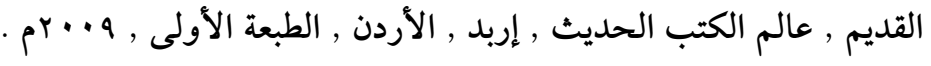


- السكاكي (أبو يعقوب محمد بن علي بن محمد) , مفتاح العلوم , طبعه ونشره نعيم زرزور ,

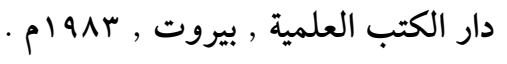

- السيوطي (جلال الدين) , شرح عقود الجمان في علمي المعاني والبيان , حققه وعلق عليه

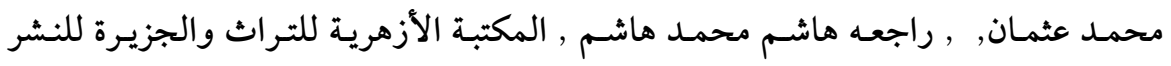

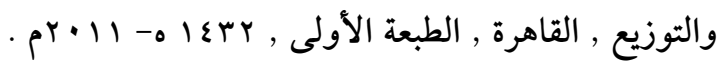

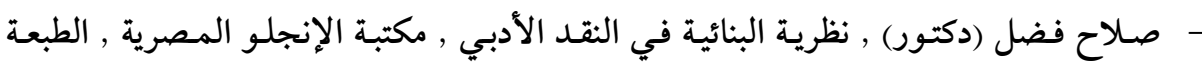

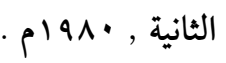

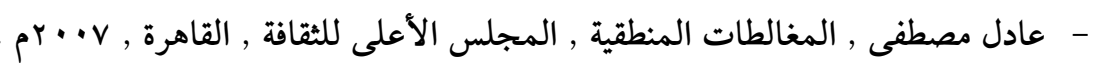

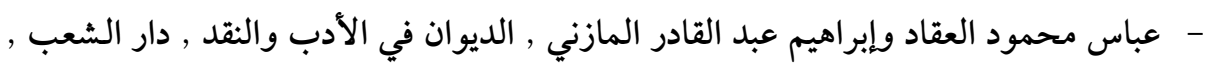

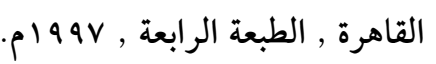

- عبد القـاهر الجرجاني , أسرار البلاغة , تحقيق هلموت ريتر , مكتبة المتنبي , القاهرة , - - عبد الله بـ المعتز , كتاب البديع , اعتنى بنشره وتحقيق المقدمة والفهارس إغناطيوس

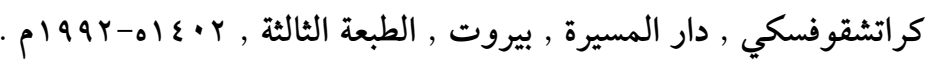
- العلوي (يحي بن حمزة بن علي اليمني) , الطراز المتضمن لأسرار البلاغة وعلوم حقائق

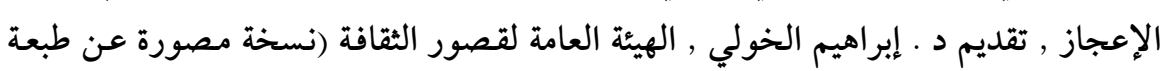

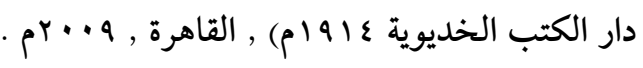

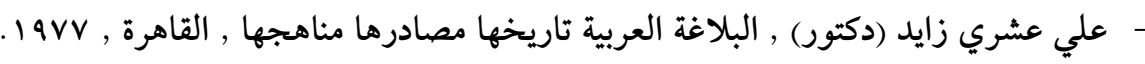

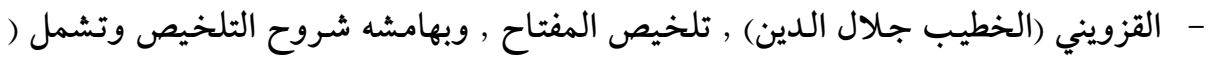

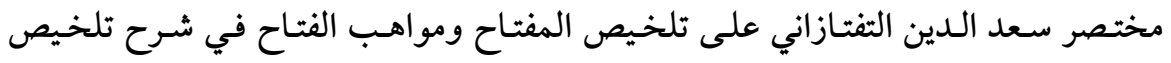
المفتاح لعبد الفتاح المغربي وعروس الأفراح في شرح تلخيص المفتاح لبهاء الدين السبكي

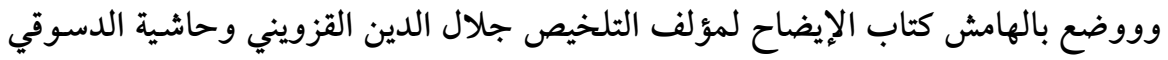
على شرح السعد ) , دار السرور , بيروت , (د-ت) .

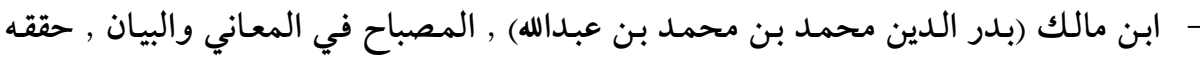

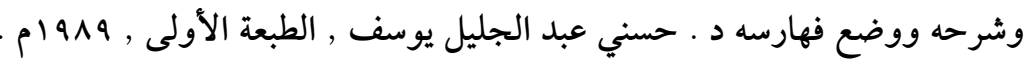

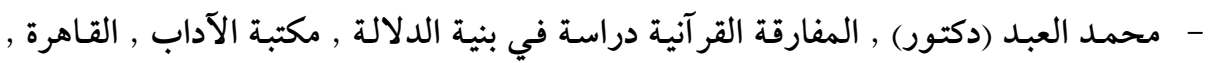

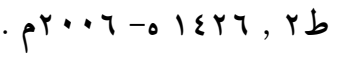


محمـد سـالم الطلبـة (دكتـور) , الحجـاج في البلاغـة المعاصـرة : بحــث في بلاغـة النقـــ المعاصر , دار الكتاب الجديد المتحدة , بيروت , الطبعة الأولى , ^ • • بم .

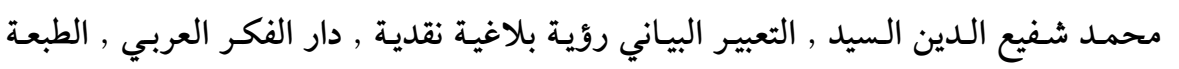

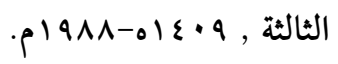
- المرزباني (أبو علي أحمد بن محمد بن الحسن المرزوقي) , الموشح في مآخذ العلماء على الشعراء في عدة أنواع من صناعة الشعر , نشره أحمد أمين وعبد السلام هارون , دار الجيل , بيروت , الطبعة الأولى || | - مصطفى سـويف , الأسسس النفسية في الإبـداع الأدبي في الشعر خاصـة , دار المعارف , القاهرة , الطبعة الثانية , 909 م. - مصطفى ناصـف , اللغـة والبلاغـة والميلاد الجديـد , دار سعاد الصباح , الكويـت , الطبعة

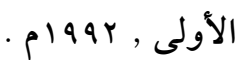
- النابلسي (عبد الغني بن إسماعيل) , نفحات الأزهار على نسمات الأسحار في مدح النبي

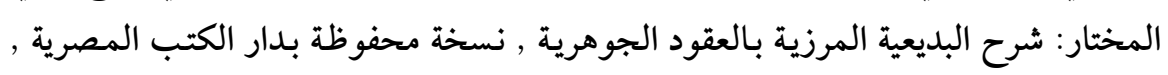

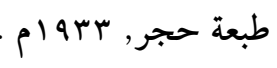

Ү - أمبرتو إيكو , التأويل والتأويل المفرط , ترجمة ناصر الحلواني , الهيئة العامة لقصور الثقافة

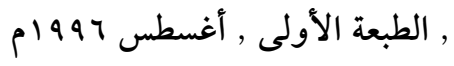
- يوري لوتمان , تحليل النص الشعري "بنية القصيدة" , ترجمة د ـ محمد فتوح أحمد , دار المعارف , القاهرة , (د-ت) . - جون كوين , بناء لغة الشعر , ترجمة د ـ أحمد درويش , الهيئة العامة لقصور الثقافة ,

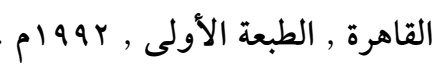

ثالثا : المعاجم: - إنعام فوال عكاوي , المعجم المفصل في علوم البلاغة المعاني البيان البديع , مراجعة

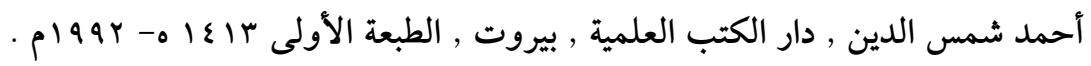
- ابن منظور , لسان العرب , طبعة مراجعة ومصححة بمعرفة نخبة من السادة الأساتذة

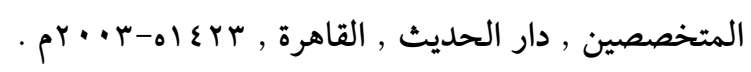
- - منير البعلبكي , قاموس المورد , دار العلم للملايين , بيروت , طبعة ع9 أم . 


\section{رابعا : اللدوريات : - ابر}

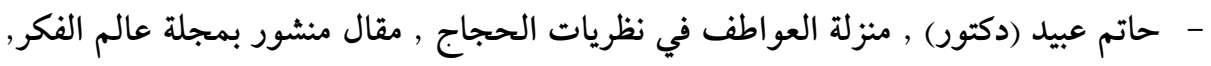

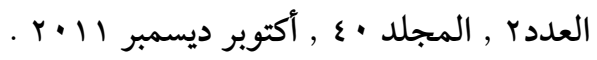

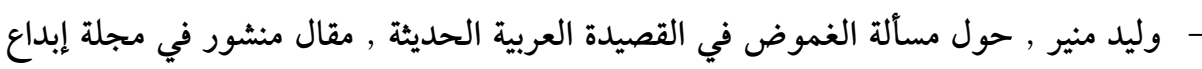

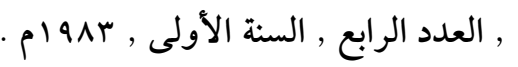

خامسا : الرسائل المخطوطة :

- إيهاب المقراني (دكتور) , أثر المنهج البلاغي للسكاكي وتلامذته في اتجاهات الإبداع

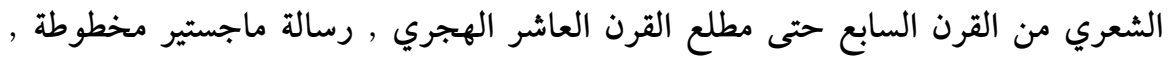

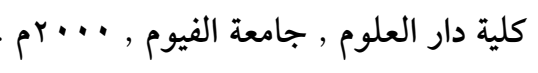

سادسا : المراجع الأجنبية :

Sylvan Barnet(and athers): Dictionary of literary terms Canstable .

$$
\text { . London , I9v }
$$

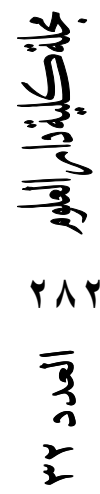

